
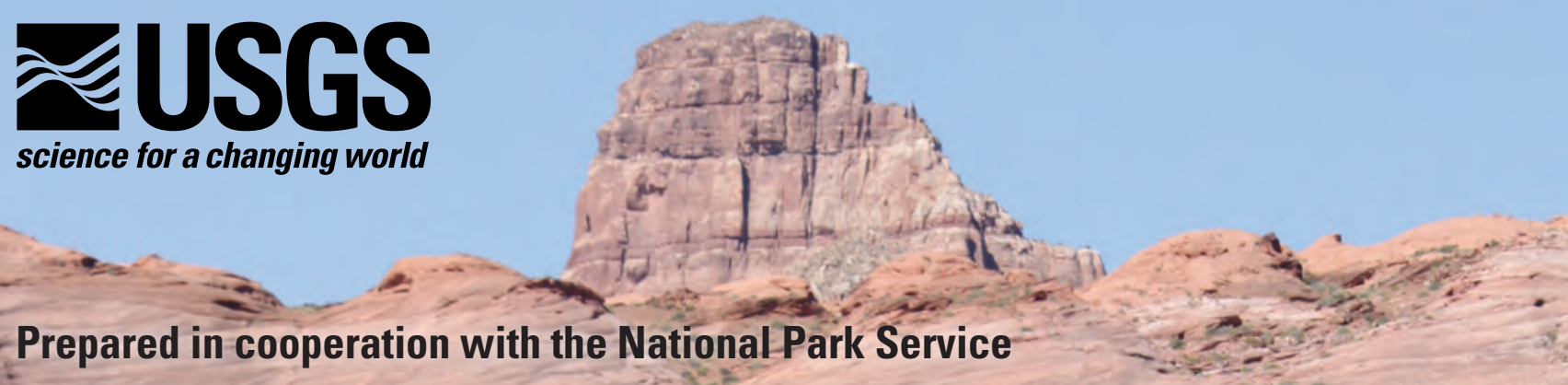

\title{
Biogeochemical and Physical Processes Controlling Mercury Methylation and Bioaccumulation in Lake Powell, Glen Canyon National Recreation Area, Utah and Arizona, 2014 and 2015
}

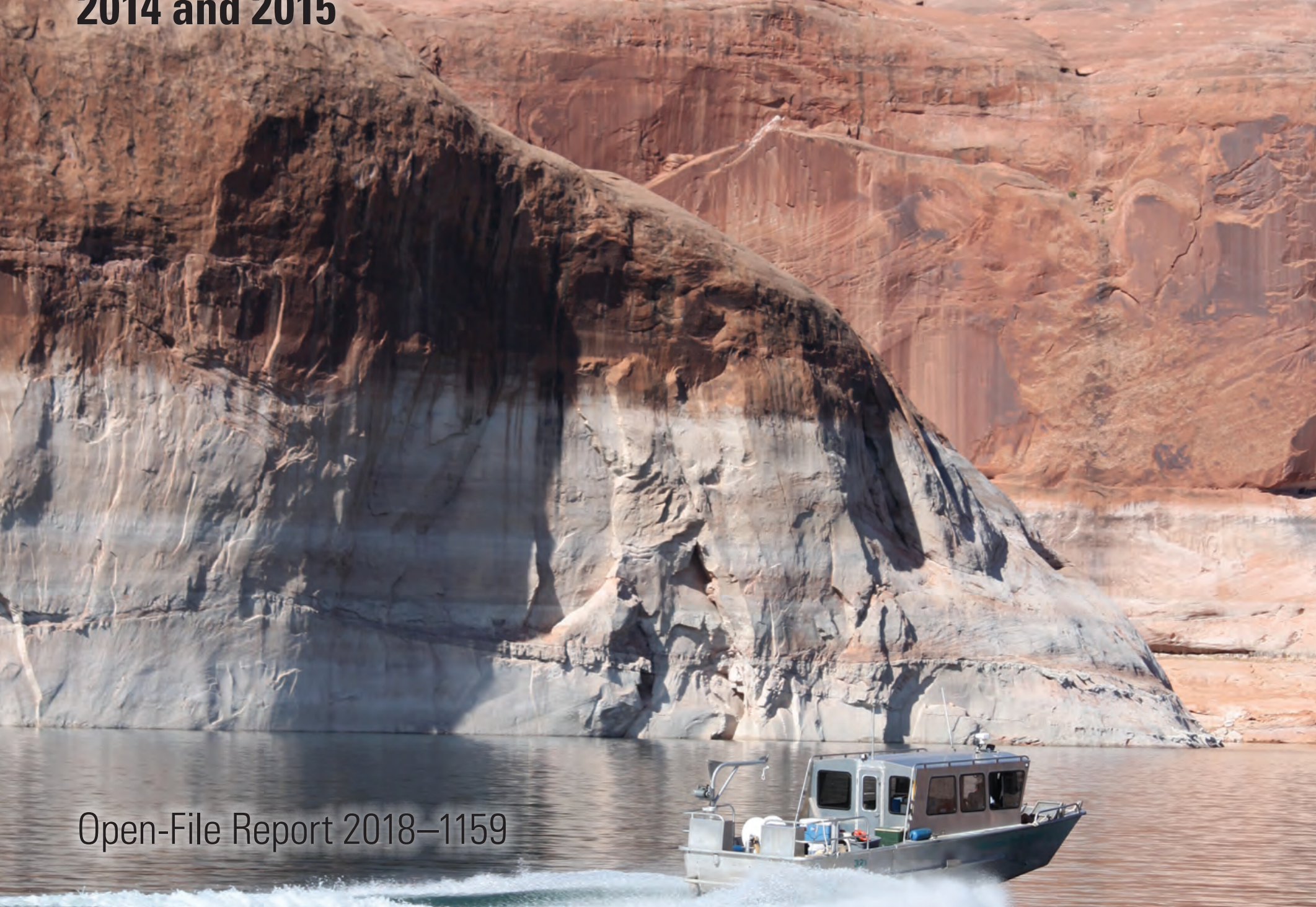


Cover. Boat transporting U.S. Geological Survey and National Park Service personnel and equipment to sampling sites on Lake Powell, Utah and Arizona, June 5, 2014. Photograph by David Naftz, U.S. Geological Survey. 


\section{Biogeochemical and Physical Processes Controlling Mercury Methylation and Bioaccumulation in Lake Powell, Glen Canyon National Recreation Area, Utah and Arizona, 2014 and 2015}

By David L. Naftz, Mark Marvin-DiPasquale, David P. Krabbenhoft, George Aiken, Eric S. Boyd, Christopher H. Conaway, Jacob Ogorek, and Gregory M. Anderson

Prepared in cooperation with the National Park Service

Open-File Report 2018-1159 


\title{
U.S. Department of the Interior \\ DAVID BERNHARDT, Acting Secretary
}

\author{
U.S. Geological Survey \\ James F. Reilly II, Director
}

U.S. Geological Survey, Reston, Virginia: 2019

For more information on the USGS - the Federal source for science about the Earth, its natural and living resources, natural hazards, and the environment-visit https://www.usgs.gov or call 1-888-ASK-USGS.

For an overview of USGS information products, including maps, imagery, and publications,

visit https://store.usgs.gov.

Any use of trade, firm, or product names is for descriptive purposes only and does not imply endorsement by the U.S. Government.

Although this information product, for the most part, is in the public domain, it also may contain copyrighted materials as noted in the text. Permission to reproduce copyrighted items must be secured from the copyright owner.

Suggested citation:

Naftz, D.L., Marvin-DiPasquale, M., Krabbenhoft, D.P., Aiken, G., Boyd, E.S., Conaway, C.H., Ogorek, J., and Anderson, G.M., 2019, Biogeochemical and physical processes controlling mercury methylation and bioaccumulation in Lake Powell, Glen Canyon National Recreation Area, Utah and Arizona, 2014 and 2015: U.S. Geological Survey Open-File Report 2018-1159, 81 p., https://doi.org/10.3133/ofr20181159.

ISSN 2331-1258 (online) 


\section{Acknowledgments}

Any use of trade, firm, or product names is for descriptive purposes only and does not imply endorsement by the U.S. Government or Montana State University. Funding for this study was provided by the U.S. Geological Survey (USGS) and National Park Service through the Water Quality Partnership Program. Fish collection by Wayne Gustaveson with the Utah Division of Wildlife Resources was instrumental in our study and is gratefully acknowledged. Laboratory and data analysis by Julie Murchie (National Park Service, Page, Arizona) was instrumental to the successful completion of this study. The manuscript was improved substantially from technical review by J. Vander Laan (Utah Department of Environmental Quality).

Additional USGS funding (salary support for M. Marvin-DiPasquale) included the Toxic Substances Hydrology Program and the Earth Systems Processes Division. Field assistance by Hillary Harms and laboratory analysis/data management by M. Arias, J.L. Agee, L.H. Kieu, E. Kakouros, and C. Fuller (USGS, Menlo Park, California) is gratefully acknowledged. Craig Stricker (USGS, Denver, Colorado) provided water-column 34-S sulfate analyses for this research. Laboratory and data analysis by Brett Poulin and Ron Antweiler (USGS, Boulder, Colo.) and field assistance by David Allen (retired USGS); Cory Angeroth, Ryan Rowland, and Chris Wilkowske (USGS, Utah Water Science Center); John DeWild and Michael Tate (USGS, Middleton, Wisconsin); and Katie Walton-Day (USGS, Lakewood, Colo.) was instrumental to the successful completion of this study. The manuscript was improved from technical review by M. Storb (USGS). 



\section{Contents}

Acknowledgments ……...................................................................................................................

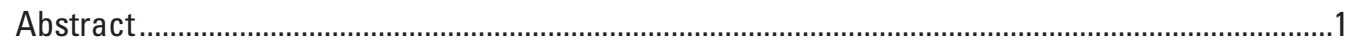

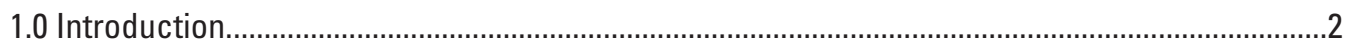

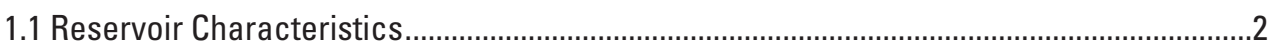

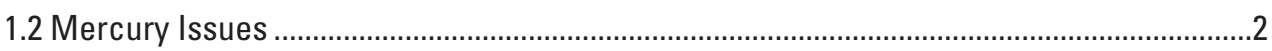

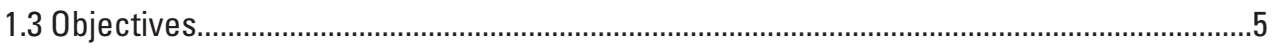

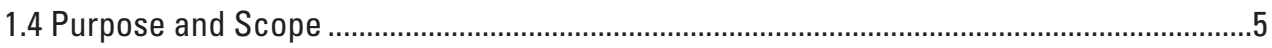

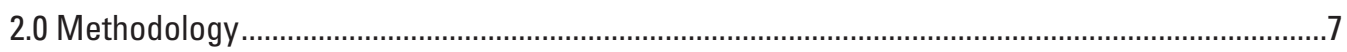

2.1 Field

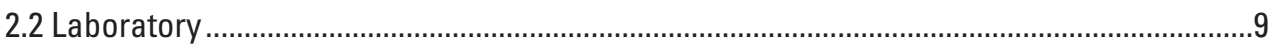

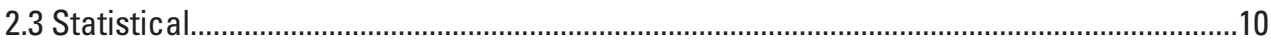

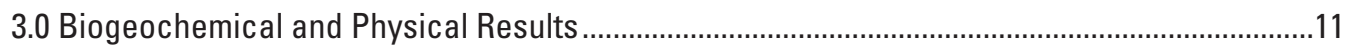

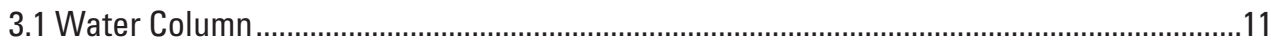

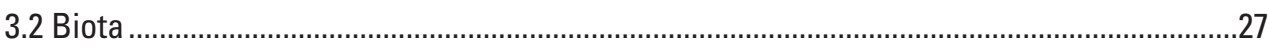

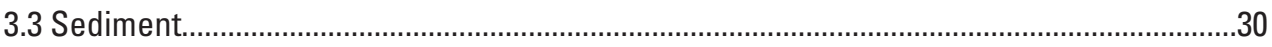

4.0 Discussion of Biogeochemical and Physical Processes ..........................................................38

4.1 Hypothesis 1 (Upper Versus Lower Reservoir) ..................................................................39

4.2 Hypothesis 2 (Reservoir Main Stem Versus River Arms/Side Canyons/Embayments) .....42

4.3 Hypothesis 3 (Early Season Versus Late Season) ..........................................................43

5.0 Implications of Study Results and Future Study Needs ........................................................46

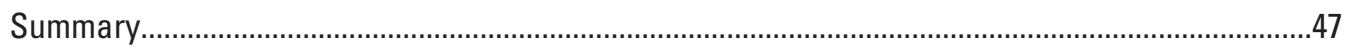

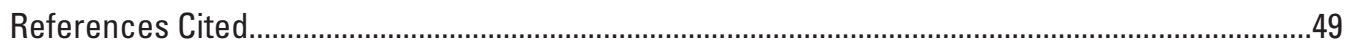

Appendix 1. Abbreviations and Definitions for Appendixes 2-6 .................................................54

Appendix 2. Arithmetic and Modeled Least Square Means for Surface Water Parameters .........57

Appendix 3. Arithmetic and Modeled Least Square Means for Surface Sediment

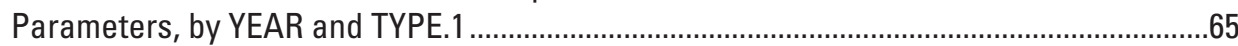

Appendix 4. Arithmetic and Modeled Least Square Means for Surface Sediment Parameters, by YEAR and TYPE.2 ………………………….............................................

Appendix 5. Arithmetic and Modeled Least Square Means for Plankton .........................................77

Appendix 6. Arithmetic and Modeled Least Square Means for Striped Bass Parameters..............81

\section{Figures}

1. Map showing sample and lake profile sites, 2014-15, Lake Powell, Arizona and Utah.

2. Schematic diagram showing conceptual model of Lake Powell with major inflows and likely area of dominant organic particles relative to the fish consumption advisory in the lower reservoir.........................................................................................

3. Map showing locations where striped bass were collected for total mercury analyses in muscle tissue during November 2014 
4. Graphs showing comparison of particulate methylmercury mass/mass concentrations in the main stem, river arms, side canyons, and embayments of Lake Powell during the May/June 2014 and August 2015 synoptic sampling trips to the location of the fish consumption advisory, Glen Canyon National Recreation Area, Arizona and Utah.

5. Graphs showing comparison of log methylmercury distribution coefficients in the main stem, river arms, side canyons, and embayments of Lake Powell during the May/June 2014 and August 2015 synoptic sampling trips to the location of the fish consumption advisory, Glen Canyon National Recreation Area, Arizona and Utah .......14

6. Graphs showing distribution of dissolved orthophosphate in the main stem of Lake Powell during the early-season (2014) and late-season (2015) synoptic sampling trips

7. Graphs showing distribution of nitrate plus nitrite in the main stem of Lake Powell during the early-season (2014) and late-season (2015) synoptic sampling trips

8. Graphs showing distribution of dissolved organic carbon in the main stem of Lake Powell during the early-season (2014) and late-season (2015) synoptic sampling trips

9. Graphs showing distribution of dissolved inorganic carbon in the main stem of Lake Powell during the early-season (2014) and late-season (2015) synoptic sampling trips

10. Graphs showing comparison of water temperature profiles in the main stem of Lake Powell during the May/June 2014 and August 2015 synoptic sampling trips to the location of the fish consumption advisory, Glen Canyon National Recreation Area, Arizona and Utah.

11. Graphs showing comparison of specific conductance profiles in the main stem, river arms, side canyons, and embayments of Lake Powell during the May/June 2014 and August 2015 synoptic sampling trips to the location of the fish consumption advisory, Glen Canyon National Recreation Area, Arizona and Utah .......20

12. Graphs showing comparison of dissolved oxygen, in percent saturation, profiles in the main stem, river arms, side canyons, and embayments of Lake Powell during the May/June 2014 and August 2015 synoptic sampling trips to the location of the fish consumption advisory, Glen Canyon National Recreation Area, Arizona and Utah

13. Graphs showing comparison of $\mathrm{pH}$ profiles in the main stem of Lake Powell during the May/June 2014 and August 2015 synoptic sampling trips to the location of the fish consumption advisory, Glen Canyon National Recreation Area, Arizona and Utah.....

14. Graphs showing comparison of turbidity profiles in the main stem of Lake Powell during the May/June 2014 and August 2015 synoptic sampling trips to the location of the fish consumption advisory, Glen Canyon National Recreation Area, Arizona and Utah......

15. Graphs showing comparison of fluorescent dissolved organic matter profiles in the main stem, river arms, side canyons, and embayments of Lake Powell during the May/June 2014 and August 2015 synoptic sampling trips to the location of the fish consumption advisory, Glen Canyon National Recreation Area, Arizona and Utah .......25

16. Graphs showing comparison of chlorophyll a profiles in the main stem of Lake Powell during the May/June 2014 and August 2015 synoptic sampling trips to the location of the fish consumption advisory, Glen Canyon National Recreation Area, Arizona and Utah 
17. Graphs showing bulk plankton comparisons in samples collected from the main stem in Lake Powell during the May/June 2014 and August 2015 synoptic sampling trips, Glen Canyon National Recreation Area, Arizona and Utah.

18. Plots displaying the results of the fish sampling completed during 2014 in Lake Powell.

19. Plot comparing the delta ${ }^{202}$ mercury $\left(\delta^{202} \mathrm{Hg}\right)$ and capital delta ${ }^{199} \mathrm{mercury}$ $\left(\Delta^{199} \mathrm{Hg}\right)$ isotopic composition in muscle tissue samples from striped bass and sediment samples collected from Lake Powell during 2014.

20. Graphs showing comparison of the abundance of ribosomal ribonucleic acid, small subunit 16 (16S rRNA) templates in the main stem, river arms, side canyons, and embayments within Lake Powell during the May/June 2014 and August 2015 synoptic sampling trips to the location of the fish consumption advisory, Glen Canyon National Recreation Area, Arizona and Utah

21. Graphs showing sediment total mercury concentration as a function of distance upstream from Glen Canyon Dam

22. Graphs showing sediment total mercury concentration normalized to organic content as a function of distance upstream from Glen Canyon Dam

23. Graphs showing sediment reactive mercury concentration as a function of distance upstream from Glen Canyon Dam

24. Graphs showing sediment reactive mercury percentage as a function of distance upstream from Glen Canyon Dam

25. Graphs showing sediment methylmercury as a function of distance upstream from Glen Canyon Dam

26. Graphs showing sediment percent methylmercury as a function of distance upstream from Glen Canyon Dam

27. Graphs showing sediment mercury-methylation rate constant as a function of distance upstream from Glen Canyon Dam.

28. Graphs showing sediment methylmercury production potential rate as a function of distance upstream from Glen Canyon Dam

29. Graphs showing sediment methylmercury degradation rate constant as a function of distance upstream from Glen Canyon Dam ...

30. Graphs showing sediment methylmercury degradation potential rate as a function of distance upstream from Glen Canyon Dam.

31. Graphs showing sediment daily rate of change for the ambient methylmercury pool (7-day incubations) as a function of distance upstream from Glen Canyon Dam ...........38

32. Bar plots depicting the model B.2 least square mean results associated with the interaction term (YEAR $\times$ TYPE.2) for sediment

33. Graphs showing comparison of dissolved oxygen, in milligrams per liter, profiles in the main stem and river arms, side canyons, and embayments of Lake Powell during the May/June 2014 and August 2015 synoptic sampling trips to the location of the fish consumption advisory, Glen Canyon National Recreation Area, Arizona and Utah 


\section{Tables}

1.1. Abbreviations and definitions for appendixes 2-6.

2.1. Arithmetic and modeled least square means for surface water parameters, by YEAR.

2.2. Arithmetic and modeled least square means for surface water parameters, by TYPE.1

2.3. Arithmetic and modeled least square means for surface water parameters, by TYPE.2

2.4. Arithmetic and modeled least square means for surface water parameters, by DEPTH.2

3.1. Arithmetic and modeled least square means for surface sediment parameters, by YEAR.

3.2. Arithmetic and modeled least square means for surface sediment parameters, by TYPE.1

3.3. Arithmetic and modeled least square means for surface sediment parameters, by YEAR $\times$ TYPE. 1

4.1. Arithmetic and modeled least square means for surface sediment parameters, by YEAR.

4.2. Arithmetic and modeled least square means for surface sediment parameters, by TYPE.2

4.3. Arithmetic and modeled least square means for surface sediment parameters, by interaction term YEAR $\times$ TYPE.2

5.1. Arithmetic and modeled least square means for plankton, by YEAR...............................77

5.2. Arithmetic and modeled least square means for plankton, by TYPE.1 ……....................78

5.3. Arithmetic and modeled least square means for plankton, by TYPE.2 …….....................79

5.4. Arithmetic and modeled least square means for plankton, by SIZE.FRAC ......................80

6.1. Arithmetic and modeled least square means for striped bass parameters .....................81 


\section{Conversion Factors}

International System of Units to U.S. customary units

\begin{tabular}{|c|c|c|}
\hline Multiply & By & To obtain \\
\hline \multicolumn{3}{|c|}{ Length } \\
\hline centimeter $(\mathrm{cm})$ & 0.3937 & inch (in.) \\
\hline millimeter $(\mathrm{mm})$ & 0.03937 & inch (in.) \\
\hline meter $(\mathrm{m})$ & 3.281 & foot $(\mathrm{ft})$ \\
\hline kilometer (km) & 0.6214 & mile (mi) \\
\hline kilometer (km) & 0.5400 & mile, nautical (nmi) \\
\hline meter $(\mathrm{m})$ & 1.094 & yard (yd) \\
\hline \multicolumn{3}{|c|}{ Volume } \\
\hline cubic meter $\left(\mathrm{m}^{3}\right)$ & 6.290 & barrel (petroleum, 1 barrel = 42 gal) \\
\hline liter $(\mathrm{L})$ & 33.81402 & ounce, fluid (fl. oz) \\
\hline liter $(\mathrm{L})$ & 2.113 & pint $(p t)$ \\
\hline liter (L) & 1.057 & quart (qt) \\
\hline liter $(\mathrm{L})$ & 0.2642 & gallon (gal) \\
\hline cubic meter $\left(\mathrm{m}^{3}\right)$ & 264.2 & gallon (gal) \\
\hline cubic meter $\left(\mathrm{m}^{3}\right)$ & 0.0002642 & million gallons (Mgal) \\
\hline cubic centimeter $\left(\mathrm{cm}^{3}\right)$ & 0.06102 & cubic inch $\left(\mathrm{in}^{3}\right)$ \\
\hline liter $(\mathrm{L})$ & 61.02 & cubic inch $\left(\mathrm{in}^{3}\right)$ \\
\hline cubic meter $\left(\mathrm{m}^{3}\right)$ & 35.31 & cubic foot $\left(\mathrm{ft}^{3}\right)$ \\
\hline cubic meter $\left(\mathrm{m}^{3}\right)$ & 1.308 & cubic yard $\left(\mathrm{yd}^{3}\right)$ \\
\hline cubic meter $\left(\mathrm{m}^{3}\right)$ & 0.0008107 & acre-foot (acre-ft) \\
\hline \multicolumn{3}{|c|}{ Flow rate } \\
\hline meter per second $(\mathrm{m} / \mathrm{s})$ & 3.281 & foot per second $(\mathrm{ft} / \mathrm{s})$ \\
\hline \multicolumn{3}{|c|}{ Mass } \\
\hline gram (g) & 0.03527 & ounce, avoirdupois (oz) \\
\hline kilogram (kg) & 2.205 & pound avoirdupois (lb) \\
\hline
\end{tabular}

Temperature in degrees Celsius $\left({ }^{\circ} \mathrm{C}\right)$ may be converted to degrees Fahrenheit $\left({ }^{\circ} \mathrm{F}\right)$ as

$$
{ }^{\circ} \mathrm{F}=\left(1.8 \times{ }^{\circ} \mathrm{C}\right)+32 .
$$

\section{Supplemental Information}

Specific conductance is given in microsiemens per centimeter at 25 degrees Celsius $\left(\mu \mathrm{S} / \mathrm{cm}\right.$ at $\left.25^{\circ} \mathrm{C}\right)$.

Concentrations of chemical constituents in water are given in either milligrams per liter (mg/L) or micrograms per liter $(\mu \mathrm{g} / \mathrm{L})$. 
Abbreviations

\begin{tabular}{|c|c|}
\hline bulk.MeHg.mass & gravimetric bulk plankton methylmercury concentration \\
\hline bulk.MeHg.vol & volumetric bulk plankton methylmercury concentration \\
\hline bulk.THg.mass & gravimetric bulk plankton total mercury concentration \\
\hline bulk.THg.vol & volumetric bulk plankton total mercury concentration \\
\hline chl.a & chlorophyll $a$ \\
\hline$\Delta$ & capital delta \\
\hline$\delta$ & delta \\
\hline DIC & dissolved inorganic carbon \\
\hline DO & dissolved oxygen \\
\hline $\mathrm{DOC}$ & dissolved organic carbon \\
\hline fDOM & fluorescent dissolved organic matter \\
\hline f.MeHg & filter-passing methylmercury \\
\hline f.THg & filter-passing total mercury \\
\hline $\mathrm{Hg}$ & mercury \\
\hline $\mathrm{k}_{\mathrm{deg}}$ & methylmercury degradation rate constant \\
\hline $\mathrm{K}_{\mathrm{d}}(\mathrm{MeHg})$ & aqueous-particulate partitioning coefficient for methylmercury \\
\hline $\mathrm{K}_{\mathrm{d}}(\mathrm{THg})$ & aqueous-particulate partitioning coefficient for total mercury \\
\hline $\mathrm{k}_{\text {meth }}$ & mercury-methylation rate constant \\
\hline $\log K_{d}(\mathrm{MeHg})$ & log methylmercury distribution coefficient \\
\hline LOI & loss on ignition \\
\hline LSM & least square mean \\
\hline M & molar \\
\hline MDP & methylmercury degradation potential \\
\hline $\mathrm{MeHg}$ & methylmercury \\
\hline MeHg/THgbulk plankton & percent of methylmercury in bulk plankton \\
\hline MLR & multiple linear regression \\
\hline MPP & methylmercury production potential \\
\hline NPS & National Park Service \\
\hline NTU & nephelometric turbidity unit \\
\hline$\%$ & per mille \\
\hline$\%$ p.MeHg & percent of particulate methylmercury \\
\hline p.MeHg & particulate methylmercury \\
\hline p.MeHg.mass & gravimetric particulate methylmercury \\
\hline PN & particulate nitrogen \\
\hline
\end{tabular}




$\begin{array}{ll}\text { POC } & \text { particulate organic carbon } \\ \text { PTFE } & \text { polytetrafluoroethylene } \\ \text { p.THg.mass } & \text { gravimetric particulate total mercury } \\ \text { RFU } & \text { relative fluorescence unit } \\ \text { RHg } & \text { reactive mercury } \\ \text { SC } & \text { specific conductance } \\ \text { 16S rRNA } & \text { ribosomal ribonucleic acid, small subunit 16 } \\ \text { T } & \text { temperature } \\ \text { THg } & \text { total mercury } \\ \text { TSS } & \text { total suspended solids } \\ \text { TURB } & \text { turbidity } \\ \text { USGS } & \text { U.S. Geological Survey }\end{array}$





\title{
Biogeochemical and Physical Processes Controlling Mercury Methylation and Bioaccumulation in Lake Powell, Glen Canyon National Recreation Area, Utah and Arizona, 2014 and 2015
}

\author{
By David L. Naftz, ${ }^{1}$ Mark Marvin-DiPasquale, ${ }^{1}$ David P. Krabbenhoft, ${ }^{1}$ George Aiken, ${ }^{1}$ Eric S. Boyd, ${ }^{2}$ \\ Christopher H. Conaway, ${ }^{1}$ Jacob Ogorek, ${ }^{1}$ and Gregory M. Anderson ${ }^{3}$
}

\section{Abstract}

Mercury monitoring results from about 300 Morone saxatilis (striped bass) muscle tissue samples collected by the State of Utah from Lake Powell resulted in a Utah/Arizona fish consumption advisory issued in 2012 for approximately the lower 100 kilometers of the reservoir. Chemical, physical, and biological data were collected during two synoptic sampling cruises on Lake Powell during May/June 2014 and August 2015 to test three hypotheses associated with a conceptual model developed to explain the observed geographic concentration gradient of $\mathrm{Hg}$ in fish tissue samples. This model proposes that in the transition from a primarily riverine system to a reservoir, there is a change in the concentration and composition of water-column particulate material, increasing in the proportion of organic content moving downstream, as the larger size fractions of the inorganic particulate load are deposited in the upper reservoir. This change alleviates light limitation of phytoplankton production and leads to a higher proportion of autochthonous primary production in the downstream direction. This, in turn, drives increased microbial methylmercury $(\mathrm{MeHg})$ production in the benthos and potentially the water column, in the downstream direction, and results in the observed elevated fish $\mathrm{Hg}$ levels in the lower part of the reservoir. The model also proposes that there are differences between the main stem of Lake Powell and side canyons, embayments, or secondary rivers entering the reservoir, in terms of $\mathrm{Hg}$ cycling dynamics and bioaccumulations, driven mainly by differences in hydrology. Finally, seasonal differences in $\mathrm{Hg}$ dynamics within the reservoir are proposed, based on seasonal dynamics associated with primary production and the physical process of seasonal stratification.

\footnotetext{
${ }^{1}$ U.S. Geological Survey.

${ }^{2}$ Montana State University.

${ }^{3}$ National Park Service.
}

A total of three statistically testable hypotheses were proposed and postulated that measurable differences in key $\mathrm{Hg}$ and non-Hg metrics exist between: (1) the upper and lower reservoir; (2) main stem and river arm/side canyon/ embayment sites; and (3) early-season (May/June 2014, less stratified) and late-season (August 2015, stratified) conditions. Statistically modeled least square means in combination with the graphical analysis of $\mathrm{Hg}$ and non-Hg parameters were used to examine the data collected during the study and test these hypotheses. Data collected during the study are included in a U.S. Geological Survey data release and are available online at https://doi.org/10.5066/F74X560J.

In general, water-column, plankton, and surface sediment samples collected during the synoptic sampling cruises are supportive of the three hypotheses associated with the conceptual model. In support of hypothesis 1 (comparing upper and lower reservoir sites), the least square mean for turbidity was higher in the upper reservoir. In contrast, surface water particulate organic carbon (as a percentage of total particulate mass), particulate $\mathrm{MeHg}$ (by mass [in nanograms per gram] and as a percentage of total mercury [THg]), and particulatedissolved partitioning coefficients for $\mathrm{THg}$ and $\mathrm{MeHg}$ were higher in the lower reservoir. Plankton THg concentrations also were significantly (probability $[p]$ less than $(<) 0.05$ ) higher in the lower reservoir. Surface sediment metrics in support of hypothesis 1 include higher $\mathrm{MeHg}$ production potential rates in the lower reservoir. In contrast, there were no statistically significant differences between the upper and lower reservoir for surface sediment percent of $\mathrm{MeHg}$ and $\mathrm{MeHg}$ concentration, percent $\mathrm{MeHg}$, or methylation rate constants. These spatial trends associated with hypothesis 1 indicate a pathway for enhanced $\mathrm{Hg}$ bioavailability in the lower reservoir.

Hypothesis 2, which tested for differences between main stem and river arm/side canyon/embayment sites, was supported by a number of water-column parameters, including particulate $\mathrm{THg}$ and $\mathrm{MeHg}$ concentrations by mass (in nanograms per gram) and percent particulate $\mathrm{MeHg}$ being significantly $(p<0.05)$ higher in the river arms, side canyons, 
and embayments relative to the main stem channel. Plankton $\mathrm{MeHg}$ concentrations (by mass [in nanograms per gram] and volume [in nanograms per liter] and as a percentage of $\mathrm{THg}$ ) were elevated in river arm/side canyon/embayment sites compared to main stem sites, indicating an enhanced potential for MeHg bioaccumulation at the base of the pelagic food web in river arms, side canyons, and embayments. In contrast, few of the sediment metrics differed between main stem and river arm/side canyon/embayment sampling sites; however, the potential for MeHg degradation in surface sediment was significantly higher in the main stem. The data indicate that river arm/side canyon/embayment sites may experience enhanced $\mathrm{Hg}$ bioaccumulation, compared to the main stem, because of higher MeHg levels at the base of the pelagic food web. This conclusion is supported by the elevated Hg detected in striped bass muscle tissue samples collected in the San Juan Arm during this study (2014). Fish collected from the lower reservoir exhibited a distinct $\mathrm{Hg}$ isotopic signature that was enriched in delta $(\delta)^{202} \mathrm{Hg}$ and capital delta $(\Delta)^{199} \mathrm{Hg}$ relative to fish samples collected from either Good Hope Bay or the San Juan Arm.

Hypothesis 3 tested for differences between early (May/ June) high-flow and late (August) low-flow seasons. This test was supported by a range of non-Hg metrics (nitrate, phosphate, chlorophyll $a$, dissolved oxygen, fluorescent dissolved organic matter, temperature, and $\mathrm{pH}$ ) that reflect the increase in chlorophyll $a$, decrease in nutrients, and buildup of stratified conditions in the transition from early- to late-season sampling periods. Significant seasonal differences also were noted for multiple $\mathrm{Hg}$ metrics, including (a) water-column filtered and particulate (by mass) $\mathrm{MeHg}$ and $\mathrm{THg}$ concentrations; (b) plankton $\mathrm{MeHg}$ and $\mathrm{THg}$ concentration (by mass); and (c) sediment percent $\mathrm{MeHg}, \mathrm{Hg}$ (II)-methylation rate constant, and microbial ribosomal ribonucleic acid, small subunit 16 (16S rRNA) abundance, all of which were higher during the late-season synoptic sampling. Overall, the surface sediment metrics are consistent with a seasonal shift from the earlyseason synoptic results, when the availability of $\mathrm{Hg}(\mathrm{II})$ exerts a primary control on $\mathrm{MeHg}$ production, to the late-season synoptic sampling, when microbial activity is a dominant driver of $\mathrm{MeHg}$ production.

\subsection{Introduction}

Lake Powell is in southeastern Utah and northern Arizona, straddling the Arizona/Utah State line (fig. 1). The reservoir was named in memory of John W. Powell, an explorer and surveyor of the Colorado River in the 1860s and 1870 s, and the second director of the U.S. Geological Survey (USGS; 1881-94). Construction of Glen Canyon Dam began in 1956, and the filling of Lake Powell began in 1963 and full reservoir capacity was attained in 1980 (National Research Council, 1996). A total of 96 percent of inflow to the reservoir is derived from the Colorado and San Juan River watersheds
(Stanford and Ward, 1991). At full pool, the reservoir has a capacity of $3.3 \times 10^{10}$ cubic meters $\left(\mathrm{m}^{3}\right)$ and a maximum depth of 170 meters (m) (Johnson and Merritt, 1979). Lake Powell is part of Glen Canyon National Recreation Area and attracts more than 3 million visitors a year (Arizona Leisure, 2012). In addition to recreational uses, the reservoir is important for water storage and power generation.

\subsection{Reservoir Characteristics}

Lake Powell is stratified during most of the year, and incomplete convective mixing happens only during winter cooling (Stanford and Ward, 1991). Wind-driven circulation is limited by the predominance of vertical shorelines in many areas of the reservoir (Potter and Pattison, 1976). A dominant feature during summer stratification is an overflow density current from Colorado River inflow that controls the depth and extent of the seasonal thermocline (Johnson and Merritt, 1979). The warmer and less saline waters that enter the reservoir during the spring freshet form a pycnocline that overlies the higher density water near the bottom of the reservoir (Stanford and Ward, 1991).

Nutrients (nitrogen, phosphorus, and silica) are loaded into the epilimnion (above the seasonal thermocline) during the annual spring freshet, which then stimulates phytoplankton production and depletes the nutrient concentration in the water column (Stanford and Ward, 1991). Much of the microbial biomass that is produced in the epilimnion settles on the chemocline. In late summer, a low dissolved oxygen (DO) layer typically develops in the seasonal thermocline and is likely caused by respiration of organic particulates that have settled on the seasonal thermocline (Johnson and Merritt, 1979). These areas of low DO within the water column could be important in promoting mercury $+2(\mathrm{Hg}[\mathrm{II}])$-methylation within the water column. Convective overturn during late summer/early fall shifts the DO minimum into the hypolimnion. During the winter months, DO is replenished in the deeper parts of the reservoir from saline underflow currents from the Colorado and San Juan Rivers (Johnson and Merritt, 1979; Johnson and Page, 1981).

\subsection{Mercury Issues}

Morone saxatilis (striped bass) fishing in Lake Powell is widely considered by fisherman to be one of the best angling experiences in the western United States. Although striped bass are a top target for fisherman at Glen Canyon National Recreation Area, monitoring data from about 300 tissue samples collected between 2005 and 2012 have indicated that striped bass from the part of Lake Powell below Dangling Rope Marina (fig. 1) consistently exceed the U.S. Environmental Protection Agency consumption advisory of 0.3 milligram per kilogram (mg/kg) (wet weight) for mercury $(\mathrm{Hg})$ (Arizona Department of Environmental Quality, 2012). This observation has generated concerns for potential unsafe $\mathrm{Hg}$ 


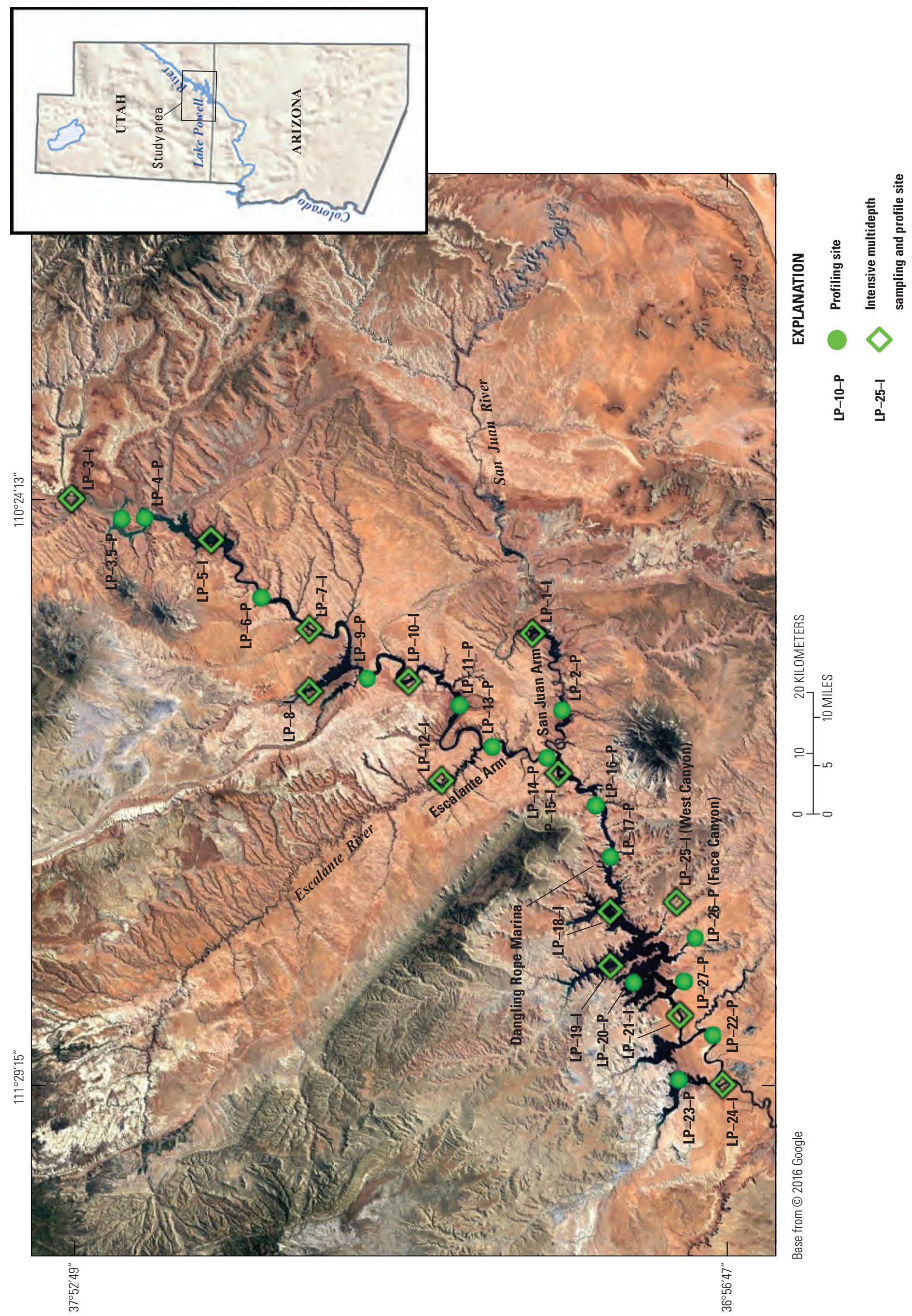

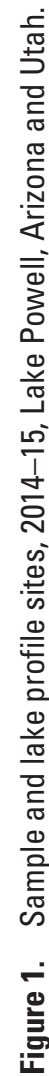


Biogeochemical and Physical Processes Controlling Mercury Methylation and Bioaccumulation in Lake Powell

exposure levels for humans, and, as a result, a fish consumption advisory for striped bass was issued in October 2012 (Utah Department of Environmental Quality, 2012) for the reservoir below Dangling Rope Marina.

No resource or issue is of greater importance to Glen Canyon National Recreation Area than Lake Powell and chemical contamination, particularly Hg biomagnification. Lake Powell is a primary subject of the park's enabling legislation, fundamental to the park's ecosystem and purposes, of the highest priority in the park's Resource Management Plan, and identified in a recent foundation planning effort as central to the park. Currently (2018), there is no creel limit for striped bass in Lake Powell (National Park Service, 2012a), which creates additional concerns for $\mathrm{Hg}$ exposure via human consumption. Furthermore, the $2012 \mathrm{Hg}$ fish consumption advisory could decrease the number of striped bass harvested by fisherman, potentially resulting in overpopulation and effects to other fish species in the Lake Powell ecosystem.

An initial survey of water, sediment, algae, crayfish, and fish tissue $\mathrm{Hg}$ in the Lake Powell ecosystem was done in 1971 through October 1972 (Standiford and others, 1973). Selected tissue samples collected from larger walleye and largemouth bass during the 1971-72 survey contained Hg concentrations that exceeded 500 parts per billion (wet weight). Also in the early 1970s, university biologists working in Glen Canyon National Recreation Area raised concerns about the siting of coal-fired power plants in the Four Corners region (Standiford and others, 1973), thereby potentially increasing Hg loading to the San Juan watershed, including Lake Powell, and subsequently increasing $\mathrm{Hg}$ concentrations in large game fish through biomagnification (Potter and others, 1975). Potter and others (1975) also determined Hg levels in reservoirtransported terrestrial plant debris were significantly higher than those of terrestrial plant materials, indicating that $\mathrm{Hg}$ is concentrated in flooded plant material. Early work by Graf (1985) concluded that much of the Hg in Lake Powell sediment is derived from weathering of geologic units, with the Chinle and Morrison Formations contributing the most Hg.

$\mathrm{Hg}$ concentrations in larger (greater than [ $>$ ] 400 millimeters [mm]) Ptychocheilus lucius (Colorado pikeminnow) collected from the Green, Yampa, White, Colorado, and San Juan Rivers within the Lake Powell watershed typically exceeded national criteria for fish tissues recommended to protect people who eat fish, as well as concentrations associated with adverse biological effects in the fish (Osmundson and Lusk, 2016). Protection of endangered fish in the Colorado River Basin is a management priority for the National Park Service (NPS). Park personnel are working with the San Juan Basin Recovery Implementation Program, which has multiple partners, including the Bureau of Reclamation, U.S. Fish and Wildlife Service, and Utah Division of Wildlife Resources, to study, monitor, and collect endangered fish species to assist in their recovery and survival within and adjacent to Glen Canyon National Recreation Area (National Park Service, 2012b).
To date (2018), modern Hg analytical tools have not been applied to increasing our understanding of the sources and physical, chemical, and biological processes that contribute to the elevated $\mathrm{Hg}$ concentrations in endangered and sport fisheries within and adjacent to Glen Canyon National Recreation Area. Hart and others (2005) collected sediment cores from delta areas in the upper part of Lake Powell and analyzed selected core sections for trace elements, including $\mathrm{Hg}$. Suboxic to anoxic conditions in the sediment, the chemocline, and the seasonal thermocline (Stanford and Ward, 1991) could potentially enhance the microbial methylation of inorganic forms of $\mathrm{Hg}$ by iron (Fe) (Kerin and others, 2006) and sulfatereducing bacteria (Compeau and Bartha, 1985). Elevated sulfate concentrations in Lake Powell (Gloss and others, 1981) could further enhance the production of methylmercury ( $\mathrm{MeHg}$ ) within the reservoir. $\mathrm{MeHg}$ is the most likely form of $\mathrm{Hg}$ that is being bioaccumulated by striped bass and the endangered Colorado pikeminnow within and adjacent to Glen Canyon National Recreation Area (Brigham and others, 2003).

The conversion of inorganic $\mathrm{Hg}$ (II) to the more toxic $\mathrm{MeHg}$ form generally takes place in the suboxic and anoxic sediment of aquatic habitats (Marvin-DiPasquale and Agee, 2003; Marvin-DiPasquale and others, 2009a). Recent research by Parks and others (2013) has identified a two-gene cluster required for $\mathrm{Hg}(\mathrm{II})$-methylation. In addition to the electron acceptors that drive these two microbial processes (sulfate $\left[\mathrm{SO}_{4}{ }^{2-}\right]$ and iron ${ }^{3}\left[\mathrm{Fe}^{3+}\right]$, respectively), other chemical parameters (dissolved organic carbon [DOC] [Graham and others, 2012], pH [Kelly and others, 2003], redox [Compeau and Bartha, 1984], sediment grain size [Bengtsson and Picado, 2008], and temperature [T] [Marvin-DiPasquale and Agee, 2003]) also are important in controlling the $\mathrm{Hg}(\mathrm{II})$-methylation process.

Recent research has indicated that $\mathrm{Hg}(\mathrm{II})$-methylation can also exist in the water column. Gascón Díez and others (2016) determined that $\mathrm{MeHg}$ can be produced in the oxic parts of the water column in lakes, and the process was specifically associated with settling organic-rich particles. Methylation activity also was detected in anoxic parts of the hypolimnion from selected lakes in Canada (Eckley and Hintelmann, 2006). Results from these studies are particularly relevant to $\mathrm{Hg}$ (II)methylation in Lake Powell because of documented oxygen depletion in the metalimnion (Stanford and Ward, 1991) and the persistence of oxic conditions in the main stem of the reservoir (Johnson and Page, 1981). In addition, Lake Powell has vertical shoreline around much of its perimeter (National Research Council, 1996), a unique feature that may increase the relative importance of water-column processes to sediment and littoral biogeochemical processes on $\mathrm{Hg}$ cycling in the reservoir.

The conceptual model shown in figure 2 provides a plausible and testable hypothesis for the persistence of elevated $\mathrm{Hg}$ in fish tissue samples collected from the lower part of the reservoir (below Dangling Rope Marina). The central feature of this conceptual model is a shift in the properties and 
proportions of water-column particles from nonbiological (clays, silts, and sand) particles in the upper reaches of the reservoir to biological (phytoplankton) particles in the lower part of the reservoir. The transition to a phytoplankton dominated system is likely driven by the settling of fluvial material as inflows enter the upper reservoir. Suspended sediment limiting light penetration and primary productivity in Lake Powell has been documented (Blinn and others, 1976). Settling of suspended sediment could increase light penetration in the upper water column, thereby stimulating phytoplankton production in the lower part of the reservoir; however, nutrient limitation (for example, phosphate) can subsequently supersede light limitation of primary production in most of the reservoir (Gloss, 1977; Gloss and others, 1980). The conceptual model is supported by a recent publication (Miller, 2012) that looked at the effect of reservoirs on the quality of DOC along the Colorado River. In Lake Powell, terrestrially derived allochthonous DOC entering Lake Powell was degraded and reservoir derived autochthonous DOC was produced.

These changing conditions from the upper to lower reservoir could have a dramatic effect on $\mathrm{MeHg}$ production and bioaccumulation. For example, the benthos in the part of the reservoir below Dangling Rope Marina would likely be more organic rich from a higher proportion of phytoplankton deposition, supporting suboxic/anoxic conditions more conducive for microbial $\mathrm{MeHg}$ production in the bottom sediment and subsequent $\mathrm{MeHg}$ flux to the overlying water column. The conceptual model further supposes suboxic to anoxic conditions in the sediments, and therefore, in the water column of the reservoir dead pool, in the lower part of the reservoir (fig. 2). This is consistent with previous work by Johnson and Page (1981) who documented that bottom water in the main stem of the reservoir remains aerobic because of advective circulation from winter season saline underflows from the Colorado and San Juan Rivers. In addition, oxygen depletion in the metalimnion has been documented throughout the reservoir in previous studies (Stanford and Ward, 1991) and was primarily the result of the accumulation of senescent phytoplankton on the chemocline.

A corollary to this conceptual model, which is depicted graphically from upstream to downstream along the main stem (fig. 2), is that similar processes may drive differences in $\mathrm{Hg}$ cycling and bioaccumulation between the main stem and side arms (terminal or ephemeral side canyons and secondary river arms). Although no examination comparing spatial differences between the main stem and side arms to Lake Powell has been previously done, these side arm features are hypothesized to have less hydraulic energy (lower flow) associated with them, which, like the lower part of the main stem, could result in lower concentrations of inorganic particulates, deeper light penetration, and ultimately higher primary production compared to the upper part of the main stem of Lake Powell in particular. This would be particularly true for terminal or ephemeral side canyons and less true for high-flow periods associated with the upstream part of the two main secondary rivers feeding into Lake Powell (the San Juan River and the Escalante River at the San Juan Arm and the Escalante Arm, respectively).

A second corollary to the conceptual model, as depicted graphically (fig. 2), is that there is a seasonal component to these dynamics. The light limitation of primary production because of high turbidity in the upper part of Lake Powell is hypothesized to be most pronounced during the high-flow part of the annual hydrograph (for example, spring and early summer) and less pronounced during the low-flow period (late summer/early fall).

\subsection{Objectives}

To better understand the physical, chemical, and biological processes controlling the geographically constrained fish consumption advisory in Lake Powell, outlined by the conceptual model (fig. 2), a study was done by the USGS, in cooperation with the NPS and in collaboration with Montana State University, through the USGS/NPS Water Quality Partnership program. Data were collected and interpreted to support or refute the following three hypotheses:

Hypothesis 1.- There are spatial differences, between the upper and lower reservoir, in key $\mathrm{Hg}$ and non- $\mathrm{Hg}$ metrics that support the conceptual model and lead to higher $\mathrm{Hg}$ concentrations in striped bass in the lower reservoir (0 to 100 kilometers [km] from Glen Canyon Dam).

Hypothesis 2.-There are spatial differences, between the reservoir main stem and river arm/side canyon/embayment sites, in key Hg and non-Hg metrics that support the conceptual model and lead to higher $\mathrm{Hg}$ concentrations in striped bass in river arm sites.

Hypothesis 3.- There are temporal differences in $\mathrm{Hg}$ and non-Hg metrics between the early-season period (May/ June 2014, before strong stratification) and the late-season period (August 2015, during stratified conditions) that lead to higher $\mathrm{Hg}$ concentrations at the base of the food web (phytoplankton and zooplankton) during the late-season period.

\subsection{Purpose and Scope}

The purpose of this report is to describe biogeochemical and physical processes controlling mercury methylation and bioaccumulation in Lake Powell, Glen Canyon National Recreation Area, Utah and Arizona. Chemical, physical, and biological data were collected during two synoptic sampling cruises on Lake Powell during May/June 2014 (early season) and August 2015 (late season) to test three hypotheses associated with a conceptual model developed to explain the observed geographic concentration gradient of $\mathrm{Hg}$ in fish tissue samples. 


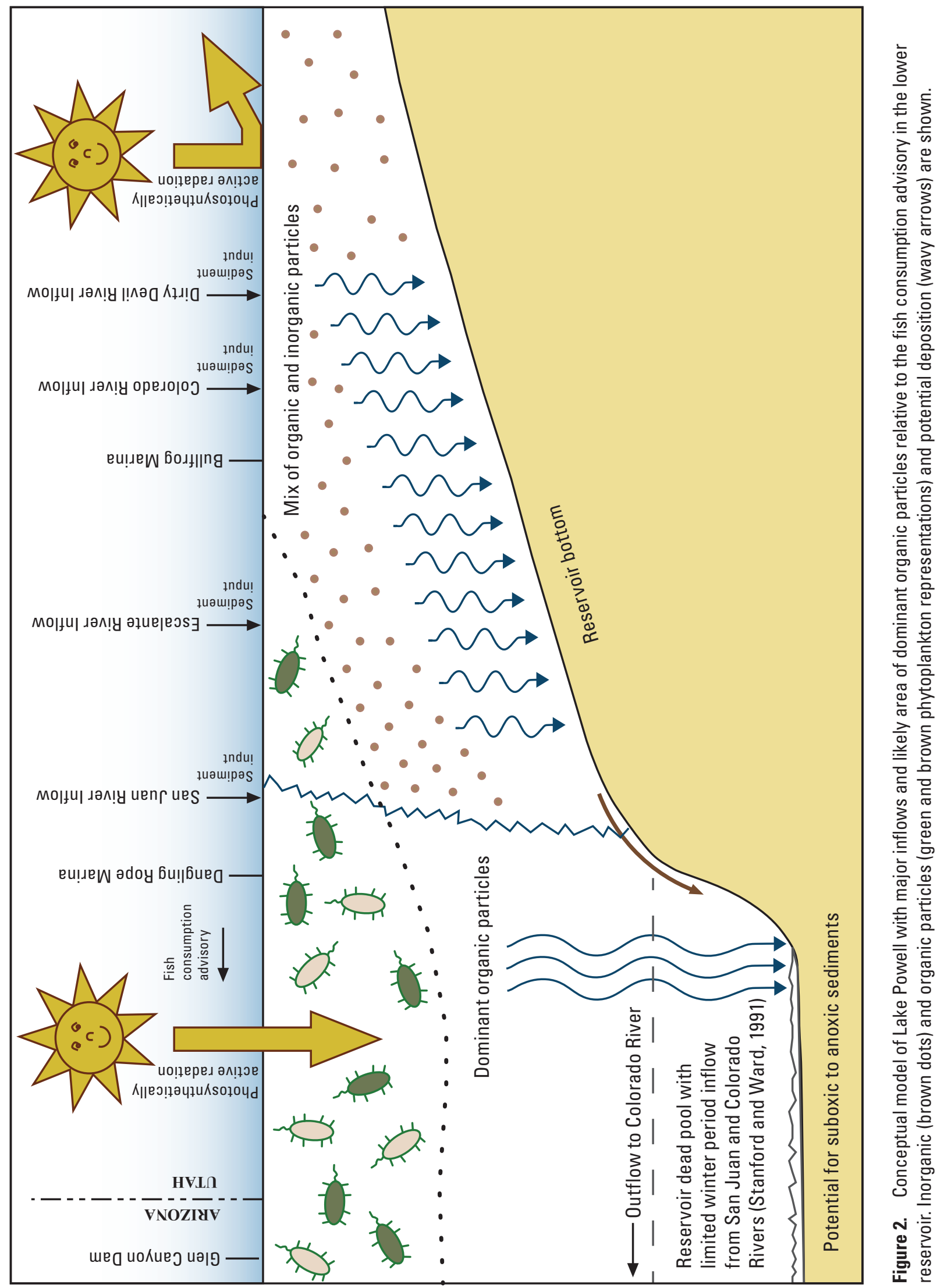




\subsection{Methodology}

Brief descriptions of field, laboratory, and statistical methods used during the study are provided in the subsequent sections. Additional detail and references on these methods and all the data presented and discussed in this report are publicly available as a USGS data release (Marvin-DiPasquale and others, 2017).

\subsection{Field}

Sampling nomenclature.- - Two types of sampling sites were designated during the two synoptic sampling trips and are identified on figure 1 . The first site type was identified with an "I," for "intensive" sampling (for example, LP-12-I), and signifies the cocollection of sediment, water-column, plankton, and molecular biology samples, in addition to a limnological profile of field parameters (that is, $\mathrm{pH}, \mathrm{DO}$, specific conductance (SC), T, and so on). The second site type was identified with a "P," for "profile" sampling (for example, LP-2-P), which signifies that only a limnological profile of in-situ field parameters was collected.

Water-column sample depth codes used during the study followed a simplified three-layer model, which uses the nomenclature of Hart and Sherman (1996): epilimnion (EPI), metalimnion (THM, for thermocline), and hypolimnion (MHY, for midhypolimnion). In addition, separate depth codes were used for samples collected $2 \mathrm{~m}$ below the water surface (SRF) and $2 \mathrm{~m}$ above the sediment-water interface (B2).

This simplistic model used to assign depth codes contrasts with the meromictic lake stratification model used in many Lake Powell studies (Johnson and Merritt, 1979; Stanford and Ward, 1991; National Research Council, 1996), which separates the water column into an upper convectively mixing layer (mixolimnion) and a lower nonmixing layer (monimolimnion). These water-column layers are separated by a chemocline, and the mixolimnion can undergo seasonal thermal stratification, being subdivided into seasonal epilimnion, metalimnion, and hypolimnion.

These sample classification approaches may create confusion when comparing the primary scientific literature on Lake Powell (for example, the hypolimnion of Hart and Sherman [1996] is the equivalent of the monimolimnion in other studies). We attempt to limit confusion in this report by referring, where possible, to the upper water column, which includes the convective mixing zone and can undergo seasonal thermal stratification and generally includes the spring overflow, autumn interflow, and withdrawal current. Reference to the lower water column includes the colder, more saline layer and includes the areas receiving winter underflow from the Colorado and San Juan Rivers.

Water-quality profiles.-A Yellow Springs Instrument/ Xylem EXO 2 sonde was used to collect water-quality profiles during the 2014 and 2015 synoptic sampling cruises. Sensors installed on the sonde included $\mathrm{pH}$, pressure, $\mathrm{SC}$, chlorophyll $a$ (chl.a), T, fluorescent dissolved organic matter (fDOM), turbidity (TURB), and DO. The $\mathrm{pH}, \mathrm{SC}$, and $\mathrm{DO}$ sensors were calibrated daily and the chl.a, fDOM, and TURB sensors were calibrated less frequently (every 3 to 5 days). Additional details on each sensor including method detection limits, calibration procedures, method references, and reporting units are included in Marvin-DiPasquale and others (2017).

Before each water-quality profile, the sensors were cleaned with the central wiper and the pressure sensor depth was reset to $0 \mathrm{~m}$. The sonde was then programed to collect and record all sensor data at 2 -second intervals. The water-quality sonde was allowed to descend through the water column at a rate of about 15 centimeters per second until reaching the bottom of the reservoir. The sonde was then retrieved to the surface, data logging was terminated, and the data were transferred to a laptop computer. Key parameters (depth, T, SC, and DO) were plotted for quality assurance checks and for the purpose of selecting subsequent water-quality sampling depths at each intensive sampling site (for example, LP-12-I).

Equipment preparation for mercury sampling.-To reduce the risk of contamination, equipment used to collect, process, and store $\mathrm{Hg}$ samples was cleaned using established methods (Wilde and others, 2009). All polytetrafluoroethylene (PTFE) containers and equipment were acid-cleaned in 4 molar (M) hydrochloric $(\mathrm{HCl})$ acid and are regularly tested for background Hg. Quartz fiber filters were precombusted at $550{ }^{\circ} \mathrm{C}$ to reduce $\mathrm{Hg}$ to the elemental state and volatilize it. Nitex screens and beakers used for plankton processing were first washed in a $0.1 \mathrm{M} \mathrm{NaOH}$ solution, followed by acidcleaning in $0.5 \mathrm{M} \mathrm{HCl}$. The Polyethylene Terephthalate Glycol bottles used to collect raw water in the field were either brand new (regularly verified from laboratory analysis as Hg-clean) or acid-cleaned between uses in the field $(0.5 \mathrm{M} \mathrm{HCl})$. When not being used, all equipment was stored in two zip-type bags to protect against external $\mathrm{Hg}$ contamination.

Water.-Water was collected using a continuous length of PTFE tubing (13-mm ID, 150-m length) attached to a short length $(20$ centimeters $[\mathrm{cm}])$ of C-Flex tubing and a peristaltic pump. The sample tubing was attached to a length of painted stainless steel that weighed approximately 20 kilograms $(\mathrm{kg})$ to provide mass at depth, with the intake of the sample tubing about $1 \mathrm{~m}$ below the end of the weight. The PTFE tube and 20-kg weight were deployed using a davit and winch with a metered cable, and whenever possible, the sampling depth (especially at deeper sites) was secondarily confirmed using onboard sound navigation and ranging equipment. At each sampling depth, about 60 liters (L) of water (three times the volume of the length of tubing) were pumped through the sample tubing to completely rinse it before sample collection. Raw water for $\mathrm{Hg}$ analyses was collected directly into an Hg-clean, 2-L Polyethylene Terephthalate Glycol bottle. Raw water for chl.a analysis was collected in a 2-L polyethylene bottle. After raw water collection, a Geotech 0.45 -micrometer $(\mu \mathrm{m})$ capsule filter was attached to the sample tube to provide filter-passing water for additional analyses (dissolved carbon, metals, anions/cations, and nutrients). All samples were stored 
on ice in a cooler until processing (typically $8-12$ hours after collection).

After field collection, raw water for $\mathrm{Hg}$ analyses was separated into filter-passing and suspended particulate fractions. Using a vacuum pump, filtration chamber, and PTFE filter tower, a measured mass of raw water was passed through a 47-mm quartz fiber filter (Whatman 1851-047, 2.2- $\mu \mathrm{m}$ nominal pore size). After filtration, the quartz fiber filter (containing the particulate matter) was stored in a PTFE petri dish and frozen until analysis. Filter-passing water was simultaneously collected into a PTFE bottle and preserved to 1 percent (volume/volume) $\mathrm{HCl}$. All aqueous and suspended particulate samples were analyzed for $\mathrm{MeHg}$ and total mercury (THg) content (Marvin-DiPasquale and others, 2017) at the USGS Mercury Research Laboratory in Middleton, Wisconsin.

Microbial biomass. - Biomass for molecular characterization of ribosomal ribonucleic acid, small subunit 16 (16S rRNA) genes from the water column was collected by filtration. Water pumped from specified depths was used to rinse 2-L polycarbonate bottles (minimum of three rinses). Biomass from the collected water was then filtered through $0.22-\mu \mathrm{m}$ Sterivex cartridge filters (Colman and others, 2016). The amount of water (as much as $2 \mathrm{~L}$ ) that was filtered was quantified and used to normalize 16S rRNA gene templates to volume. Filter cartridges were placed in sterile 50-milliliter $(\mathrm{mL})$ centrifuge tubes and were immediately frozen on dry ice after collection.

Plankton.-Plankton samples were collected with a plankton net (63- $\mu \mathrm{m}$ mesh, 1-m hoop diameter) towed vertically through the epilimnion to the surface $(20 \mathrm{~m}$ deep at most sites). The plankton net was deployed using a davit and winch with a metered cable. Once at the surface, the net was rinsed with water (from the outside of the net) to concentrate the contents into the cod end bucket. The plankton collected in the cod end bucket were then quantitatively transferred to a PTFE bottle and stored in the dark on ice until processing could be done (within 8-12 hours).

Each plankton sample was separated into four size fractions using Nitex screens at progressively smaller sizes (500, 243,118 , and 63-micron mesh). The Nitex screen was retained in a $15-\mathrm{cm}$ sewing hoop that rested on top of a beaker. The plankton sample was slowly poured through the screen and generously rinsed with Hg-clean water. The part of the sample that passed through the net was captured, and the screening procedure was repeated for the next smaller size fraction. Each plankton sample captured on the Nitex screen was frozen and further contained in a PTFE envelope and plastic bag for transport to the USGS Mercury Research Laboratory in Middleton, Wis. At the laboratory, the sample was lyophilized, removed from the Nitex screen, weighed, and analyzed for $\mathrm{MeHg}$ and THg using methods described in Marvin-DiPasquale and others (2017).

Plankton samples were collected at the intensive sample sites during the early-season (2014) and late-season (2015) synoptic sampling trips. Most of the plankton samples were composites of the upper $20 \mathrm{~m}$ of the water column (table 4 in
Marvin-DiPasquale and others, 2017). Exceptions to the 20-m sample composite depth were made at LP-8-I because of shallow (less than $[<] 20 \mathrm{~m}$ ) water depths. Plankton samples also were composited from 0 - to 2-m and 0 - to $40-\mathrm{m}$ water-column depths at selected sample sites (table 4 in Marvin-DiPasquale and others, 2017). Plankton samples were further separated into four size fractions before $\mathrm{Hg}$ analysis (table 4 in MarvinDiPasquale and others, 2017).

Bulk plankton $\mathrm{Hg}$ concentrations were back-calculated from the four size fractions and are the sum of the relative $\mathrm{Hg}$ contribution from each size fraction divided by the dry mass of the bulk sample. Bulk plankton $\mathrm{Hg}$ concentrations represent the sample before separation into individual size fractions. For the purposes of this report, only statistics done on the bulk plankton measurements are discussed. Plankton Hg metrics are reported on a dry weight basis and are assessed as a mass of Hg per mass of plankton (mass/mass, in nanograms per gram), as a mass of plankton $\mathrm{Hg}$ per volume of water (mass/ volume, in nanograms per liter), and as a ratio of $\mathrm{MeHg} / \mathrm{THg}$ (in percent). In addition, plankton biological mass (dry weight) per volume water (in milligrams per liter) also is reported for individual size fractions and bulk plankton. Finally, the percent gravimetric (milligram of plankton per milligram of total suspended solids [TSS], as a percentage) concentrations of bulk plankton mass were calculated from the bulk plankton volumetric concentrations and the mean of the independently collected TSS $(>0.7 \mu \mathrm{m}$, in milligrams per liter) concentrations in the top $0-25 \mathrm{~m}$ of the water column.

Fish.-Striped bass were collected by the Utah Division of Wildlife Resources from three areas of Lake Powell (Good Hope Bay, Wahweap Bay, and the San Juan Arm) during November 2014 (fig. 3). Each fish was weighed and measured in the field and then frozen before transport to the USGS Mercury Research Laboratory in Middleton, Wis., for analysis. Constituents measured in the muscle tissue samples included percent moisture, $\mathrm{THg}$, and selected $\mathrm{Hg}$ isotopes (table 5 in Marvin-DiPasquale and others, 2017).

Sediment.--Sediment was initially collected using a stainless steel Eckman style box core $(23 \times 23 \times 30 \mathrm{~cm})$. Upon retrieval, the surface 0 - to $2-\mathrm{cm}$ (approximate) interval was collected using an acid-cleaned plastic sheet $(8 \times 8 \mathrm{~cm})$ and transferred into acid-cleaned and precombusted $240 \mathrm{ml}$ glass mason jars (two per site), which were completely filled to exclude any atmosphere. The mason jars were stored chilled in a cooler with freezer packs until further processing the same day. A thermocouple temperature probe was used to measure the surface sediment temperature immediately upon core retrieval. Subsamples also were collected from the box core for electrochemical probe measurement of $\mathrm{pH}$ and redox (Marvin-DiPasquale and others, 2008) within 15 minutes of box core retrieval. The $\mathrm{pH}$ probe was calibrated and the accuracy of the redox probe was verified daily, immediately before use.

Upon returning to the houseboat (field laboratory), the mason jars containing the sediment were transferred to a disposable glove bag, which was fully flushed with zero-grade 


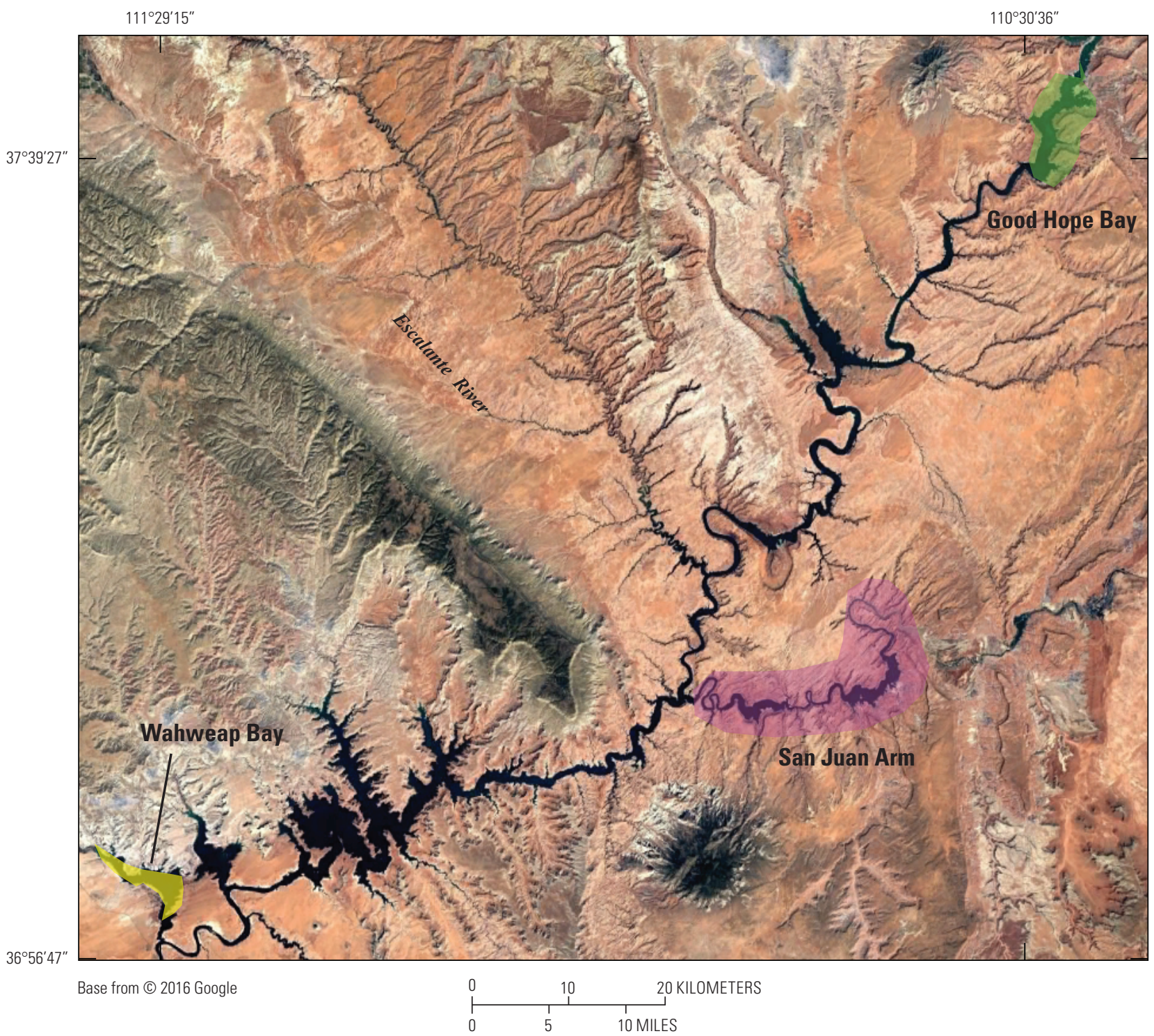

Figure 3. Locations where striped bass were collected for total mercury analyses in muscle tissue during November 2014. Fish were collected by the Utah Division of Wildlife Resources. Total mercury analyses in the fish tissue samples were completed by the U.S. Geological Survey Mercury Research Laboratory in Middleton, Wisconsin, and the results are reported in Marvin-DiPasquale and others (2017, table 5).

$\mathrm{N}_{2}$ gas before opening the mason jars and subsampling. Sediment from the 1/2-pint mason jars (two per site) was emptied into a single clean plastic zip-seal bag and homogenized.

Subsamples for the following sediment constituents were then collected with acid-cleaned plastic sampling tools, transferred to acid-cleaned crimp sealable vials, and then frozen on dry ice and stored frozen until analysis: $\mathrm{THg}, \mathrm{MeHg}$, inorganic reactive mercury $(\mathrm{RHg})$, iron $(\mathrm{Fe})$ speciation, total reduced sulfur, organic content (as percent loss on ignition [LOI]), dry weight and porosity, grain size (as percent less than $63 \mu \mathrm{m}$ ), and $16 \mathrm{~S}$ rRNA. The remaining sediment was transferred back into one of the 1/2-pint jars and subsequently stored chilled (5 degrees Celsius $\left[{ }^{\circ} \mathrm{C}\right]$ ) until further subsampling at the
USGS laboratory in Menlo Park, California (within 3-12 days from the date of field collection).

\subsection{Laboratory}

Most laboratory analyses done on surface water, sediment, and tissue samples as part of the current study have been previously detailed. The ScienceBase data release associated with this report (Marvin-DiPasquale and others, 2017) summarizes the specific analytes assayed for surface water, sediment, and tissue and includes the analyte abbreviation codes, analyte units, the analytical laboratory, detection limits (where 
appropriate), and the associated references where more details regarding methods are included. Instances where the specific assay conditions were unique to this study and (or) modifications were made relative to the method(s) cited in the ScienceBase data release, additional detail is provided in this section.

Total suspended solids. - Surface water TSS samples were collected by filtering the maximum available volume, or filterable volume, of surface water through individually preweighed glass fiber filters (Whatman, GF/F), with volumes ranging from 45 to $2,230 \mathrm{~mL}$. Filters were stored frozen until being returned to the USGS laboratory in Menlo Park, Calif., where they were freeze dried and reweighed. The difference between the postfreeze-dried weight and the preuse weight was calculated to determine TSS for the volume of sample passed through each filter.

Methylation and demethylation incubations.-For each benthic site, sediment was subsampled into six 13-cubic centimeter crimp sealed serum vials (incubation bottles; 3.00 plus or minus $[ \pm] 0.05$ grams $[\mathrm{g}]$ per bottle) under anaerobic conditions ( $\mathrm{N}_{2}$ flushed glove bag) for MeHg production potential (MPP) and MeHg degradation potential (MDP) incubations. MPP incubations were completed with ${ }^{200} \mathrm{HgCl}_{2}$ stable isotope, using an approach similar to that used previously (Chalmers and others, 2013; Marvin-DiPasquale and others, 2011; Marvin-DiPasquale and others, 2014). MDP incubations were completed with ${ }^{201} \mathrm{Hg}$ stable isotope enriched methylmercury $\left(\mathrm{Me}^{201} \mathrm{Hg}\right)$, using an approach somewhat similar to that used previously for ${ }^{14} \mathrm{C}$ radioisotope enriched methylmercury $\left({ }^{14} \mathrm{CH}_{3} \mathrm{Hg}\right)$ incubations (Marvin-DiPasquale and others, 2000, 2003; Marvin-DiPasquale and Agee, 2003). Stable isotope enriched $\mathrm{Me}^{201} \mathrm{Hg}$ was synthesized from inorganic ${ }^{201} \mathrm{Hg}$ (II) methylated with methylcobalamin (Rouleau and Block, 1997). After extraction into high-performance liquid chromatography grade methylene chloride and back-extraction into water, the final concentrated $\mathrm{Me}^{201} \mathrm{Hg}$ solution was 588 nanograms per milliliter ( $\mathrm{ng} / \mathrm{mL}$ ) (as $\mathrm{Hg}$ ), with an enriched isotope purity of 96.2 percent ${ }^{201} \mathrm{Hg}$, preserved in 1 percent trace metal grade $\mathrm{HCl}$.

The incubation bottles were preincubated for 3 hours at a temperature that was $\pm 1{ }^{\circ} \mathrm{C}$ of the mean sediment temperature determined in the field for that sampling event, which ranged from 11.5 to $11.8{ }^{\circ} \mathrm{C}$ for the two sampling events. The $\mathrm{Hg}$ isotope working stocks were prepared in diluted phosphate buffer and were $1,500 \mathrm{ng} / \mathrm{mL}(\mathrm{pH}=1.4)$ for ${ }^{200} \mathrm{Hg}(\mathrm{II})$ and $30 \mathrm{ng} / \mathrm{mL}$ $(\mathrm{pH}=2.2)$ for $\mathrm{Me}^{201} \mathrm{Hg}$. After preincubation, three vials per site were injected with $0.1 \mathrm{~mL}$ of the ${ }^{200} \mathrm{Hg}$ (II) working stock and three vials were injected with $0.1 \mathrm{~mL}$ of the $\mathrm{Me}^{201} \mathrm{Hg}$ working stock, resulting in final nominal amendment concentrations of 50 nanograms per gram (ng/g) (wet weight) for ${ }^{200} \mathrm{Hg}$ (II) and $1 \mathrm{ng} / \mathrm{g}$ (wet weight) for $\mathrm{Me}^{201} \mathrm{Hg}$, respectively. Then, one of the three incubation vials from each MPP and MDP set was immediately flash frozen in a bath of dry ice and ethanol and then transferred to a $-80{ }^{\circ} \mathrm{C}$ freezer. This sample represented the site-specific killed control. The remaining two MPP and MDP incubation vials for each site were returned to the incubator and maintained at the predetermined temperature for 2 days (48 hours) for MPP incubations and for 7-8 days for MDP incubations. After the incubation period, all the incubation vials were similarly flash frozen and stored at $-80^{\circ} \mathrm{C}$ until further processing. Upon thawing, the previously incubated samples were assayed for either $\mathrm{Me}^{200} \mathrm{Hg}$ (for MPP incubations) or $\mathrm{Me}^{201} \mathrm{Hg}$ (for MDP incubations) via isotope dilution inductively coupled plasma mass spectrometry after extraction with potassium hydroxide and methanol $\left(\mathrm{KOH} / \mathrm{CH}_{3} \mathrm{OH}\right)$ as previously described (Marvin-DiPasquale and others, 2011). Changes in the ambient $\mathrm{Me}^{202} \mathrm{Hg}$ pool also were quantified via ICP-MS to assess net $\mathrm{MeHg}$ production or degradation during the 7- to 8-day incubations associated with the MDP samples.

Microbial biomass. - Quantitative polymerase chain reaction was used to determine the abundances of 16S rRNA gene templates as a proxy for microbial biomass (archaea, bacteria, and chloroplast encoding eukarya) in filtered water samples collected at intensive sampling sites during the May/June 2014 and August 2015 synoptic sampling trips.

\subsection{Statistical}

A series of fixed-effects and mixed-effects linear least square models was used to statistically examine surface water, sediment, plankton, and fish data collected in this study with respect to sampling event and location. All statistical modeling was completed using JMP® statistical software (version 11.2.1, SAS Institute, Inc.). Statistical significance was set at a type II error probability level of $p<0.05$. When $p>0.05$ but $<0.10$, differences were identified as "weakly significant." Each parameter being tested was first assessed for normality of distribution. In cases where the data were not normally distributed, a natural logarithm (log base-e) transformation of the data was modeled, and final reported error results were back-transformed using the delta method (Seber, 1982).

Surface water parameters (table 3 in Marvin-DiPasquale and others, 2017) were statistically analyzed with a linear mixed-effects model (model A) of the general form:

\section{$Y S W=Y E A R+T Y P E .1+T Y P E .2+D E P T H+S I T E[$ random $]$} (model A)

where

$Y S W \quad$ is any surface water parameter;

YEAR is the study year (2014-early season, 2015late season);

TYPE.1 is the location type (main stem, arm);

TYPE.2 is the location type as upper versus lower reservoir and the division is above or below where the San Juan River enters the main stem of Lake Powell (upper, lower); 
DEPTH is the water-column depth coded into three limnological categories as determined from EXO 2 water-quality sonde profiles of DO, $\mathrm{T}$, and SC ( $2 \mathrm{~m}$ below surface [SURF], epilimnion plus thermocline [EPI+THM], hypolimnion plus sample collected $2 \mathrm{~m}$ above the sediment/water interface [HYP+B2]); and

SITE $[$ random $]$ is all individual sites as a random variable. No interaction terms were included in this model.

Because of the limited number of observations associated with surface sediment parameters for the complete dataset (number of observations $[n]=28$ ), two separate linear mixed-effects models were developed to examine the sediment parameters (table 2 in Marvin-DiPasquale and others, 2017). The first examined YEAR and TYPE. 1 spatial differences and the interaction between the two:

\section{$Y S E D=Y E A R+T Y P E .1+Y E A R \times T Y P E .1+S I T E[$ random $]$} (model B.1)

where

YSED is any surface sediment parameter,

$Y E A R$ is the study year as per model A,

TYPE. 1 is the location (main stem versus arm sites) as per model A,

$Y E A R \times T Y P E .1$ is the interaction term, and SITE [random] is all individual sites as a random variable. The inclusion of the interaction term allows for the assessment of differences between main stem versus arm sites (TYPE.1) that also varied by sampling event (that is, by $Y E A R$ ).

The second mixed-effects model applied to sediment data examined YEAR and TYPE.2 spatial differences and the interaction between the two:

\section{$Y S E D=Y E A R+T Y P E .2+Y E A R \times T Y P E .2+S I T E[$ random $]$} (model B.2)

where

YSEDis any surface sediment parameter, YEARis the study year as per model A, TYPE.2is the location type as upper versus lower reservoir as per model A,

$Y E A R \times T Y P E .2$ is the interaction term, and SITE $[$ random $]$ is all individual sites as a random variable.

Plankton data (table 4 in Marvin-DiPasquale and others, 2017) were statistically analyzed with a linear mixed-effects model (model C) of the general form:

$Y P L A N K T O N=Y E A R+T Y P E .1+T Y P E .2+F R A C+S I T E[$ random $]$ (model C) where

YPLANKTON is any plankton parameter,

$Y E A R$ is the study year as per model A,

TYPE.1 is the location (main stem versus arm sites) as per model A,

TYPE.2 is the location type as upper versus lower reservoir as per model $\mathrm{A}$,

FRAC is the sieved size fraction $(63-118 \mu \mathrm{m}$, 118-243 $\mu \mathrm{m}, 243-500 \mu \mathrm{m},>500 \mu \mathrm{m})$, and SITE $[$ random $]$ is all individual sites as a random variable. No interaction terms were included in this model.

Fish data (table 5 in Marvin-DiPasquale and others, 2017) were statistically analyzed with a linear fixed-effect model (model D) of the general form:

$Y F I S H=A R E A$

(model D)

where

YFISH is the THg concentration in striped bass standardized to a common length of $420 \mathrm{~mm}$ according to the method described in Eagles-Smith and others (2016), and

$A R E A \quad$ is the three areas where fish were collected during November 2014 at Good Hope Bay, San Juan Arm, and Wahweap Bay (fig. 3).

\subsection{Biogeochemical and Physical Results}

All the water, plankton, fish, and sediment data discussed in this section are included in Marvin-DiPasquale and others (2017). The discussion of the results is organized into three subsections by sampling media: (1) water, (2) biota (including microbial data), and (3) sediment. Within each subsection, the results are presented by individual chemical constituents or groups of chemical constituents. The depth of the penstocks used for water release during power generation (Vernieu, 2010) also was added to selected profile plots to aid in data interpretation. Appendixes 2-6 present the arithmetic and modeled least square means for surface-water, surface-sediment, plankton, and striped-bass parameters.

\subsection{Water Column}

Mercury.-Filter-passing water was analyzed for $\mathrm{MeHg}$ and THg. Filter-passing total (f.THg) and methylmercury (f.MeHg) concentrations are reported as nanograms per liter. Particulate matter was analyzed for $\mathrm{MeHg}$ (p.MeHg) and $\mathrm{THg}$ (p.THg); particulate concentrations are reported as $\mathrm{Hg}$ mass per particulate mass (mass/mass, in nanograms per gram) and 
as $\mathrm{Hg}$ mass per volume of water (mass/volume, in nanograms per liter). Aqueous-particulate partitioning was calculated for $\mathrm{MeHg}$ (coefficient $\left.\left[\mathrm{K}_{\mathrm{d}}(\mathrm{MeHg})\right]\right)$ and $\mathrm{THg}$ (coefficient $\left.\left[\mathrm{K}_{\mathrm{d}}(\mathrm{THg})\right]\right)$ and is reported as liters per kilogram.

Across Lake Powell, concentrations of f.MeHg and p.MeHg were extremely low. MeHg in filter-passing water was analytically detectable (greater than the instrument detection limit) in only 57 (61 percent) of the 94 samples collected within the lake throughout both years. Among those 57 samples, only 11 (12 percent) exceeded the reporting limit at the USGS Mercury Research Laboratory $(0.04 \mathrm{ng} / \mathrm{L})$. Similarly, many of the measurements of $\mathrm{MeHg}$ in particulate matter within Lake Powell were below instrument detection, and detectable levels (determined per analytical batch) were in 66 (70 percent) of 94 samples, of which only 24 ( 29 percent) exceeded the lower reporting limit (0.01 nanogram [ng]).

The p.MeHg mass/mass concentration was consistently higher in the lower one-half of the reservoir during the earlyseason (2014) and late-season (2015) synoptic sampling trips (fig. 4). During 2014, water in the lower $90 \mathrm{~km}$ of the main stem of Lake Powell and extending from the reservoir bottom to about $(\sim) 30 \mathrm{~m}$ below the water surface contained elevated $\mathrm{MeHg}$ concentrations in the suspended particulates relative to the upper reservoir ( $>100 \mathrm{~km}$ above Glen Canyon Dam, main stem). During 2015, the upper $10 \mathrm{~m}$ of the water column in the upper part of the main stem $(>100 \mathrm{~km}$ above Glen Canyon Dam) contained elevated p.MeHg (fig. 4). This area of elevated p.MeHg mass/mass concentrations continued to the lower part of the main reservoir channel, extending to depths of $\sim 60 \mathrm{~m}$ below the water surface. The 2015 synoptic data also indicate elevated p.MeHg concentration in water depths exceeding $90 \mathrm{~m}$ below the water surface in the lower $(<110 \mathrm{~km}$ above Glen Canyon Dam) part of the main stem (fig. 4).

The river arms, side canyons, and embayments sampled during 2014 and 2015 display variable p.MeHg mass/mass concentrations (fig. 4). The four river arm/side canyon/embayment sites that were sampled during 2014 usually contained p.MeHg concentrations below $3 \mathrm{ng} / \mathrm{g}$; however, the surface sample from site LP-8-I did exhibit a slightly higher p.MeHg concentration $(3.54 \mathrm{ng} / \mathrm{g})$. In contrast, four of the five river arm/side canyon/embayments sites sampled during 2015 contained p.MeHg concentrations exceeding $\sim 3 \mathrm{ng} / \mathrm{g}$ in at least part of the water column. Side canyon LP-25-I (not sampled in 2014) contained elevated (>8.5 ng/g) p.MeHg concentrations throughout the water column to a depth of $28 \mathrm{~m}$ below the surface (fig. 4).

The log methylmercury distribution coefficient (log $\mathrm{K}_{\mathrm{d}}[\mathrm{MeHg}]$ ) metric is a measure of the partitioning of $\mathrm{MeHg}$ from the water-column aqueous phase (filter passing) onto suspended particulates. Increasing $\log \mathrm{K}_{\mathrm{d}}[\mathrm{MeHg}]$ indicates that $\mathrm{MeHg}$ preferentially partitions to the particulate phase (from the aqueous phase). Decreasing particulate grain size, increasing organic content, and increasing reduced sulfur concentrations can increase $\mathrm{K}_{d}[\mathrm{MeHg}]$ values. The $\log \mathrm{K}_{\mathrm{d}}[\mathrm{MeHg}]$ values in water-column samples from Lake Powell collected during 2014 and 2015 ranged from 2.76 to 5.65 liters per kilogram (fig. 5). The lower 70 to $100 \mathrm{~km}$ of the main stem of Lake Powell exhibited the highest $\log \mathrm{K}_{\mathrm{d}}[\mathrm{MeHg}]$ values during the 2014 and 2015 synoptic sampling trips (fig. 5). With the exception of site LP-8-I (a side embayment), side canyons and river arms sampled during August 2015 generally exhibited elevated $(>5) \log \mathrm{K}_{\mathrm{d}}[\mathrm{MeHg}]$ values at multiple depths (fig. 5). The uppermost sections of the main stem, $>190 \mathrm{~km}$ above Glen Canyon Dam, consistently exhibited the lowest $\log \mathrm{K}_{\mathrm{d}}[\mathrm{MeHg}]$ values during the 2014 and 2015 synoptic sampling trips (fig. 5).

Phosphorus.-The concentrations of dissolved orthophosphate $\left(\mathrm{PO}_{4}{ }^{3-}\right)$ were typically about 0.010 milligrams per liter $(\mathrm{mg} / \mathrm{L})$ or less and had a uniform distribution with depth within the reservoir. Concentrations measured during the late-season synoptic sampling were typically below the limit of detection $(2 \mu \mathrm{g} / \mathrm{L})$. Early-season dissolved $\mathrm{PO}_{4}{ }^{3-}$ concentrations generally decrease from the upper reservoir towards Glen Canyon Dam (fig. 6).

Dissolved nitrogen.-Dissolved nitrate plus nitrite $\left(\mathrm{NO}_{3}{ }^{-}+\mathrm{NO}_{2}^{-}\right)$concentrations ranged from about 0.1 to $0.5 \mathrm{mg} / \mathrm{L}$ nitrogen $(\mathrm{N})$ for all sites and depths. The $\mathrm{NO}_{3}{ }^{-} \mathrm{NO}_{2}{ }_{2}$ concentrations were lower in the surface and upper part of the water column compared to the lower part of the water column (fig. 7) and in the arms of the reservoir compared to the main stem (appendix 2). In addition, $\mathrm{NO}_{3}^{-}+\mathrm{NO}_{2}^{-}$was lower during the late-season synoptic sampling as a result of much lower surface water $\mathrm{NO}_{3}{ }^{-}$concentrations that season. Total ammonia $\left(\mathrm{NH}_{4}\right)$, representing $\mathrm{NH}_{3}, \mathrm{NH}_{4}^{+}$, and $\mathrm{NH}_{4} \mathrm{OH}$, ranged from about 0.01 to $0.15 \mathrm{mg} / \mathrm{L} \mathrm{N}$, and concentrations were higher during the late-season synoptic sampling (average $0.13 \mathrm{mg} / \mathrm{L} \mathrm{N}$ ) compared to those in the early season (average $0.04 \mathrm{mg} / \mathrm{L} \mathrm{N}$ ), and in arm sites compared to main stem sites, although this latter difference was principally driven by earlyseason data (appendix 2).

Dissolved carbon.-DOC concentrations, typically about 3-4 mg/L carbon (C), indicated an enrichment in the upper part of the water column (fig. 8). The values for stable carbon isotopic composition of DOC (delta $[\delta]{ }^{13} \mathrm{C}$-DOC) were all about -26 per mille (\%) (Marvin-DiPasquale and others, 2017). Specific ultraviolet absorption at 254 nanometers (nm) (SUVA254) values ranged from about 1.5 to $3.0 \mathrm{~L} / \mathrm{mg}$ carbon per meter of path length, and were relatively higher (that is, more terrestrial, aromatic, and labile) in the upper water column compared to lower reservoir and bottom layer water (appendix 2).

Dissolved inorganic carbon (DIC) concentrations were relatively lower ( 25 to $35 \mathrm{mg} / \mathrm{L} \mathrm{C}$ ) in the upper part of the water column (fig. 9) compared to water in the bottom layer (in which concentrations were usually greater than about $35 \mathrm{mg} / \mathrm{L} \mathrm{C}$ ). Overall, DIC was lower in late-season sampling compared to early-season sampling, and lower in river arm/ side canyon/embayment sites compared to main stem sites (appendix 2). The stable carbon isotopic composition of DIC $\left(\delta^{13} \mathrm{C}\right.$-DIC) was enriched in surface water $(-6.3 \pm 0.2 \%)$ compared to the bottom zone (about $-8.6 \pm 0.1 \%$ ) (appendix 2). 


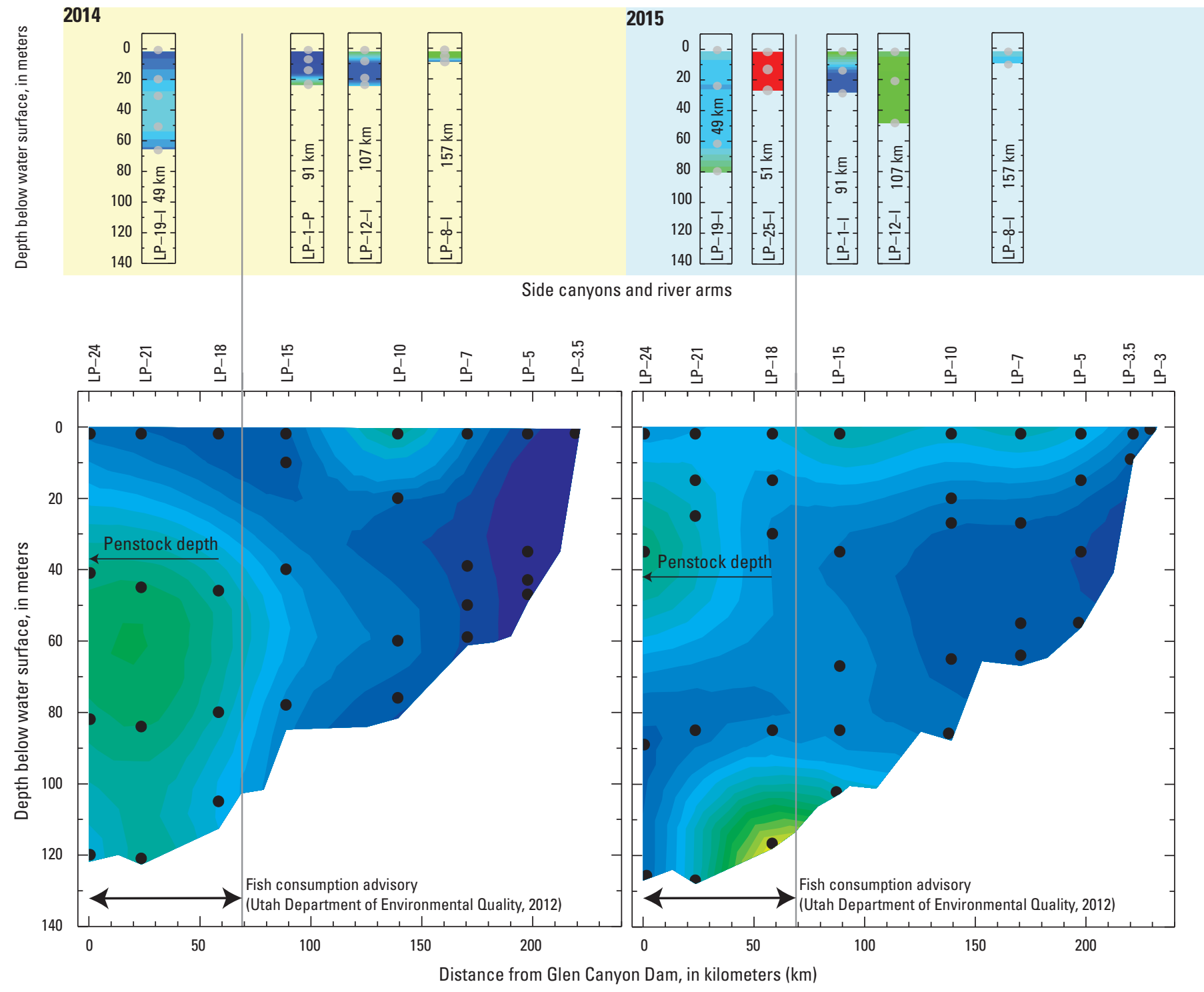

EXPLANATION

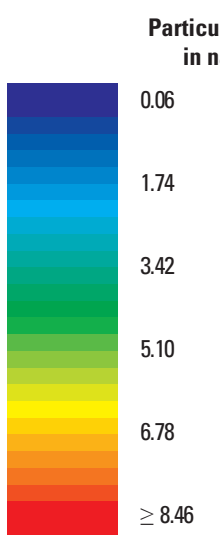

Figure 4. Comparison of particulate methylmercury mass/mass concentrations in the main stem, river arms, side canyons, and embayments of Lake Powell during the May/June 2014 and August 2015 synoptic sampling trips to the location of the fish consumption advisory, Glen Canyon National Recreation Area, Arizona and Utah. Symbols indicate depth of water sample. 


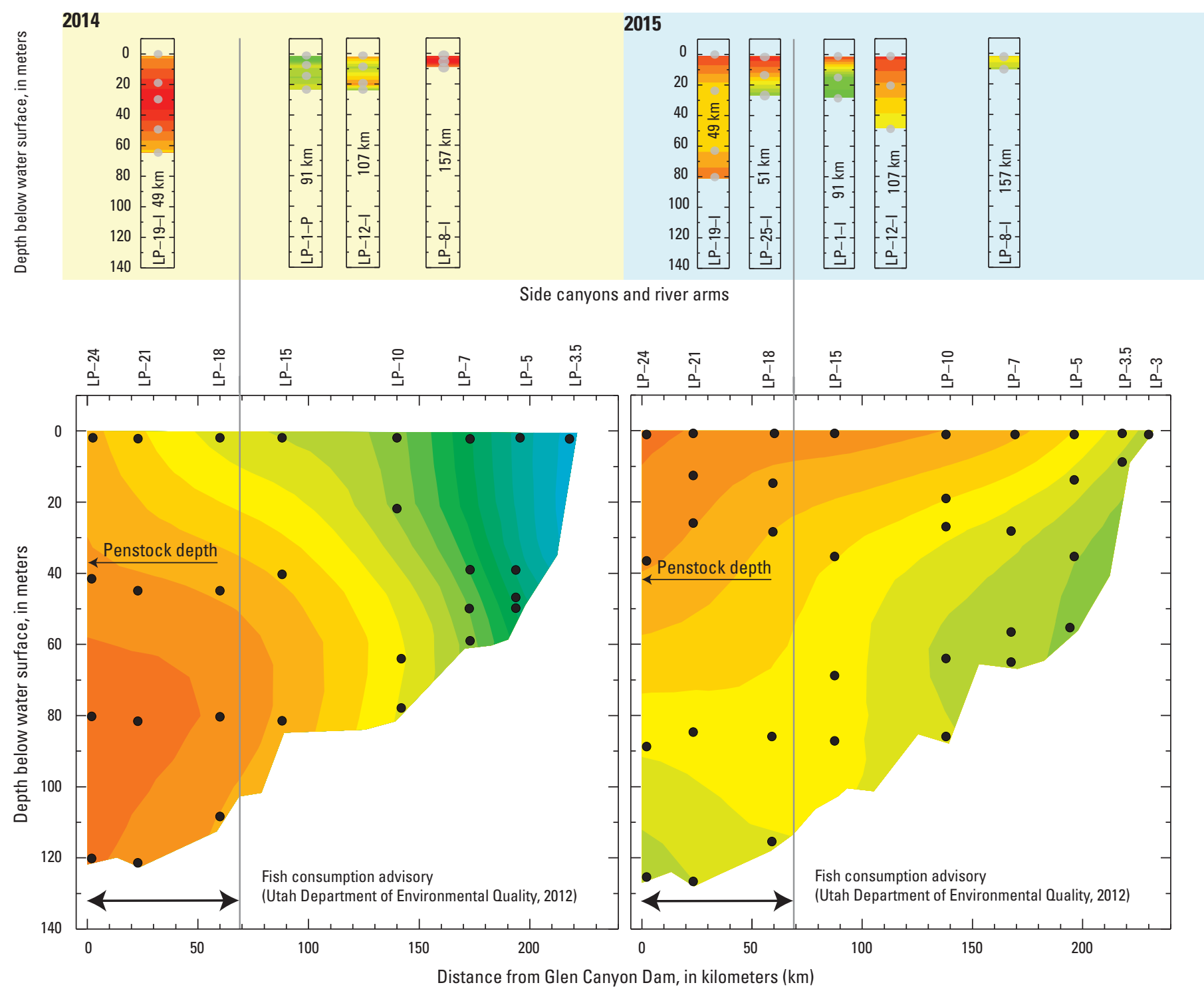

\section{EXPLANATION}

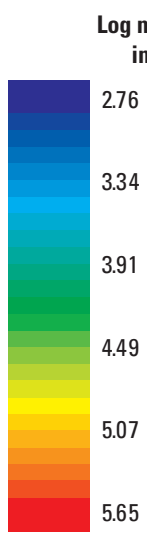

Figure 5. Comparison of log methylmercury distribution coefficients in the main stem, river arms, side canyons, and embayments of Lake Powell during the May/June 2014 and August 2015 synoptic sampling trips to the location of the fish consumption advisory, Glen Canyon National Recreation Area, Arizona and Utah. Symbols indicate depth of water sample. 

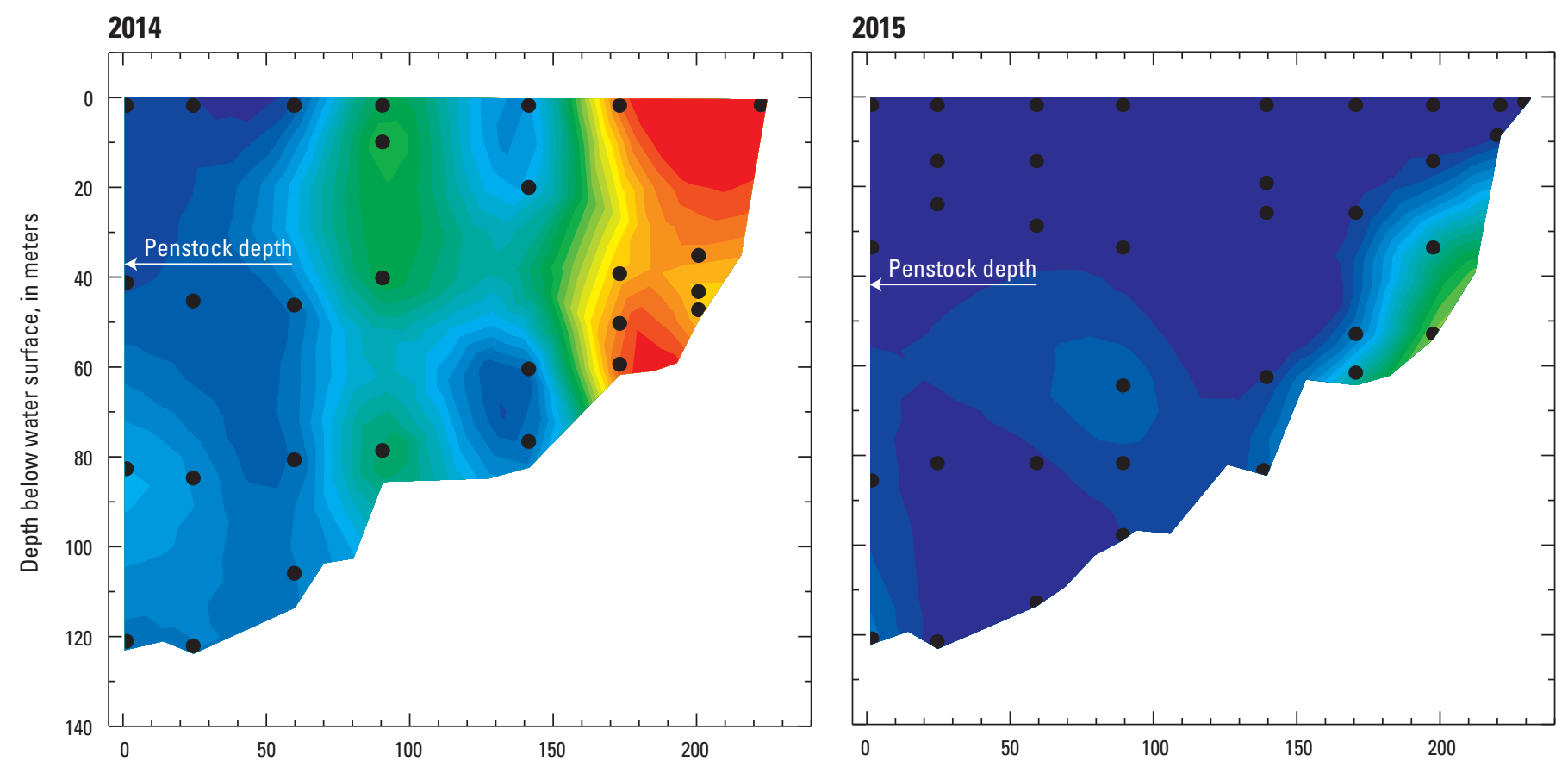

Distance from Glen Canyon Dam, in kilometers

\section{EXPLANATION}

Dissolved orthophosphate, in milligrams per liter

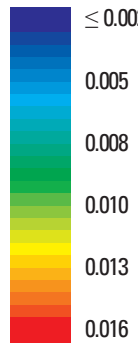

- Water sampling location and depth

Figure 6. Distribution of dissolved orthophosphate in the main stem of Lake Powell during the early-season (2014) and late-season (2015) synoptic sampling trips.

Elemental and isotopic composition of particulate matter, CNO.- In the early-season synoptic sampling during 2014, about 70 percent of samples had particulate organic carbon (POC) concentrations (by volume) below the reporting or minimum detection limit. The volume of the sample for particulate analyses was increased in the late-season synoptic sampling during 2015, increasing detection limits so that only 10 percent of samples were below the reporting limit. As a result, the least square mean (LSM) model results for POC (appendix 2), especially differences by season, must be considered with caution. Concentrations of POC (above the minimum detection limit and reporting limit) range from about 0.1 to $0.6 \mathrm{mg} / \mathrm{L}$, with a median of $0.2 \mathrm{mg} / \mathrm{L}$ (appendix 2). POC concentrations were typically higher in surface water compared to POC concentrations in the rest of the water column (Marvin-DiPasquale and others, 2017). The relative fraction of
POC in suspended material (percent POC by mass) is higher in the lower reservoir (LSM=12.4 \pm 1.5 percent) compared to the upper reservoir ( $\mathrm{LSM}=6.5 \pm 0.7$ percent) and higher in surface water compared to bottom zone of the reservoir water column (appendix 2).

Similar to the situation with POC, during the early-season synoptic sampling in 2014, 90 percent of samples had particulate nitrogen (PN) concentrations (by volume) below the reporting or minimum detection limit (Marvin-DiPasquale and others, 2017). After the increase in sample volume for the late-season synoptic sampling during 2015, 60 percent of samples were still below the reporting limit for PN. The detectable PN data (by volume or mass, PN or percent PN) are associated with relatively high values for POC. Concentrations of PN (by volume) above reporting limits ranged from about 0.01 to $1.0 \mathrm{mg} / \mathrm{L}$ with a median of about $0.04 \mathrm{mg} / \mathrm{L}$ 


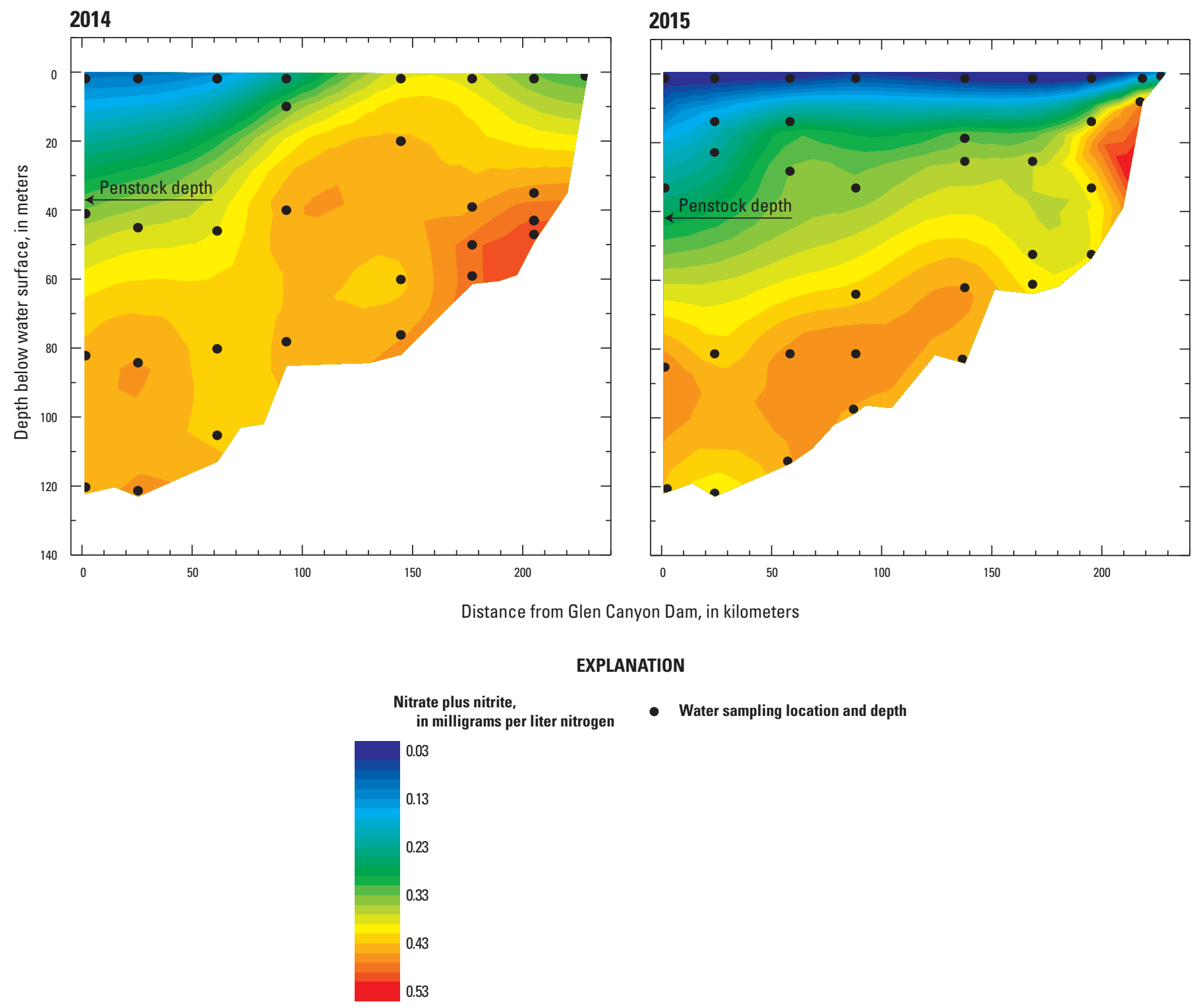

Figure 7. Distribution of nitrate plus nitrite in the main stem of Lake Powell during the early-season (2014) and late-season (2015) synoptic sampling trips.

(Marvin-DiPasquale and others, 2017). In the late-season synoptic sampling, concentrations of PN were higher in the upper reservoir (median $0.2 \mathrm{mg} / \mathrm{L}$ ) compared to the lower reservoir $(0.03 \mathrm{mg} / \mathrm{L})$. More than 90 percent of the percent $\mathrm{PN}$ data range from 0.5 to 5 percent, and, in the late-season synoptic sampling, percent PN was higher in the upper reservoir (median 3 percent) compared to the lower reservoir (2 percent). For samples with particulate $\mathrm{C}$ and $\mathrm{N}$ above the reporting limit, about 90 percent had a POC/PN molar ratio ranging from 8 to 12, and had a median of 10 (or PN/POC of 0.08 to 0.12 , median 0.1 ), which trended slightly higher than the modified Redfield C/N ratio of $8.3(166 / 20)$ calculated by Sterner and others (2008) across freshwater and marine systems, which observed higher $\mathrm{C} / \mathrm{N}$ ratios for freshwater systems.
As with elemental concentration results (and for similar reasons), there were many observations for isotopic composition that were below reporting limits in the early season and relatively more samples above reporting limits in the late season. Most results for stable carbon isotopic composition of POC $\left(\delta^{13} \mathrm{C}-\mathrm{POC}\right)$ were below the reporting limit in the earlyseason synoptic sampling, whereas $>90$ percent of samples were above the reporting limit in the late season (MarvinDiPasquale and others, 2017). The late-season $\delta^{13} \mathrm{C}-\mathrm{POC}$ data indicate relatively enriched values in Colorado River and San Juan River inputs $\mathrm{LP}-1,-3$, and $-5\left(\delta^{13} \mathrm{C}-\mathrm{POC}-12\right.$ to $\left.-27 \%\right)$, and "remote input" sites (upper watershed sites) were -16 to $-24 \%$. Along the main stem of the reservoir, $\delta^{13} \mathrm{C}$-POC values typically indicated a fairly narrow range ( -27 to $-29 \%$ ) and became progressively more enriched, moving from LP -7 


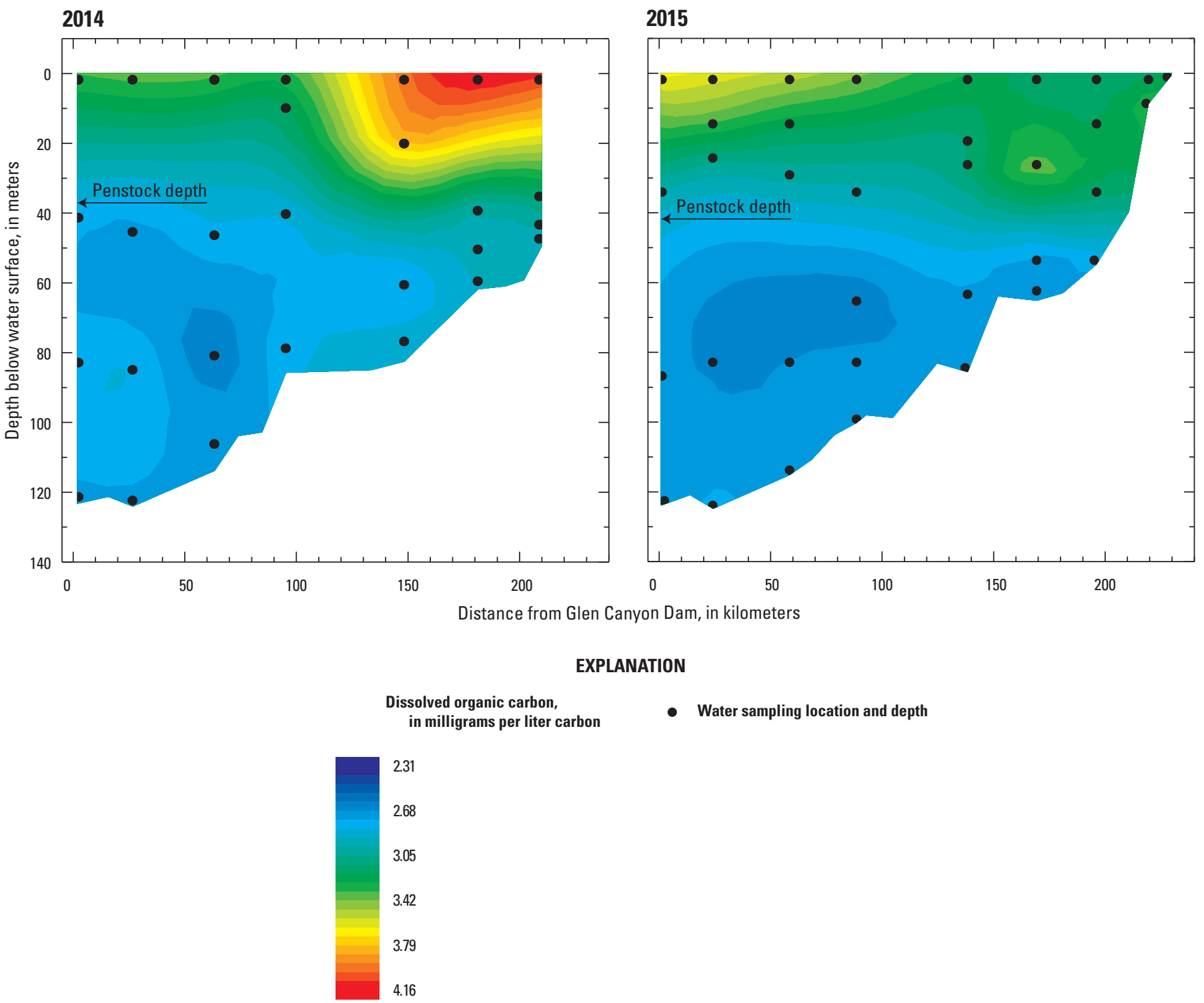

Figure 8. Distribution of dissolved organic carbon in the main stem of Lake Powell during the early-season (2014) and late-season (2015) synoptic sampling trips.

$(-29 \%)$ towards LP-21 $(-27 \%)$. Few values $(n=4)$ for stable nitrogen isotopic composition of PN $\left(\delta^{15} \mathrm{~N}-\mathrm{PN}\right)$ were above the reporting limit in the early-season synoptic sampling, but results were typically +2 to $+3 \%$ (Marvin-DiPasquale and others, 2017). In the late season, $\delta^{15} \mathrm{~N}-\mathrm{PN}$ was +5 to $+10 \%$.

Field parameters.-To provide supporting information for the interpretation of the water, plankton, and sediment chemistry results, detailed limnological profiles were completed at each of the main-channel and river arm/side canyon/ embayment intensive monitoring sites (for example, LP-24-I) (fig. 1). Limnological profiles also were collected at "profile only" sites (for example, LP-2-P), strategically located to supplement the data collected at each of the intensive sampling sites in the main stem and river arm/side canyon/embayment sites (fig. 1). Field parameters collected at all the profile sites during both synoptic sampling trips included water depth, T, DO, pH, SC, TURB, fDOM, and chl.a. Raw data for each of the limnological profiles collected during 2014 and 2015 are included in Marvin-DiPasquale and others (2017).

Individual profiles from all main-channel sites sampled during the May/June 2014 and August 2015 synoptic sampling cruises were merged and contoured based on main stem distance from Glen Canyon Dam and depth below the water surface at the time of sampling. In addition, lake profile data collected from river arm/side canyon/embayment sites also were contoured and compared to main stem profiles for selected constituents (DO, SC, and fDOM). These contoured profiles were constructed to document within-reservoir and earlyseason (May/June 2014) versus late-season (August 2015) comparisons relative to chemical, physical, and biological 


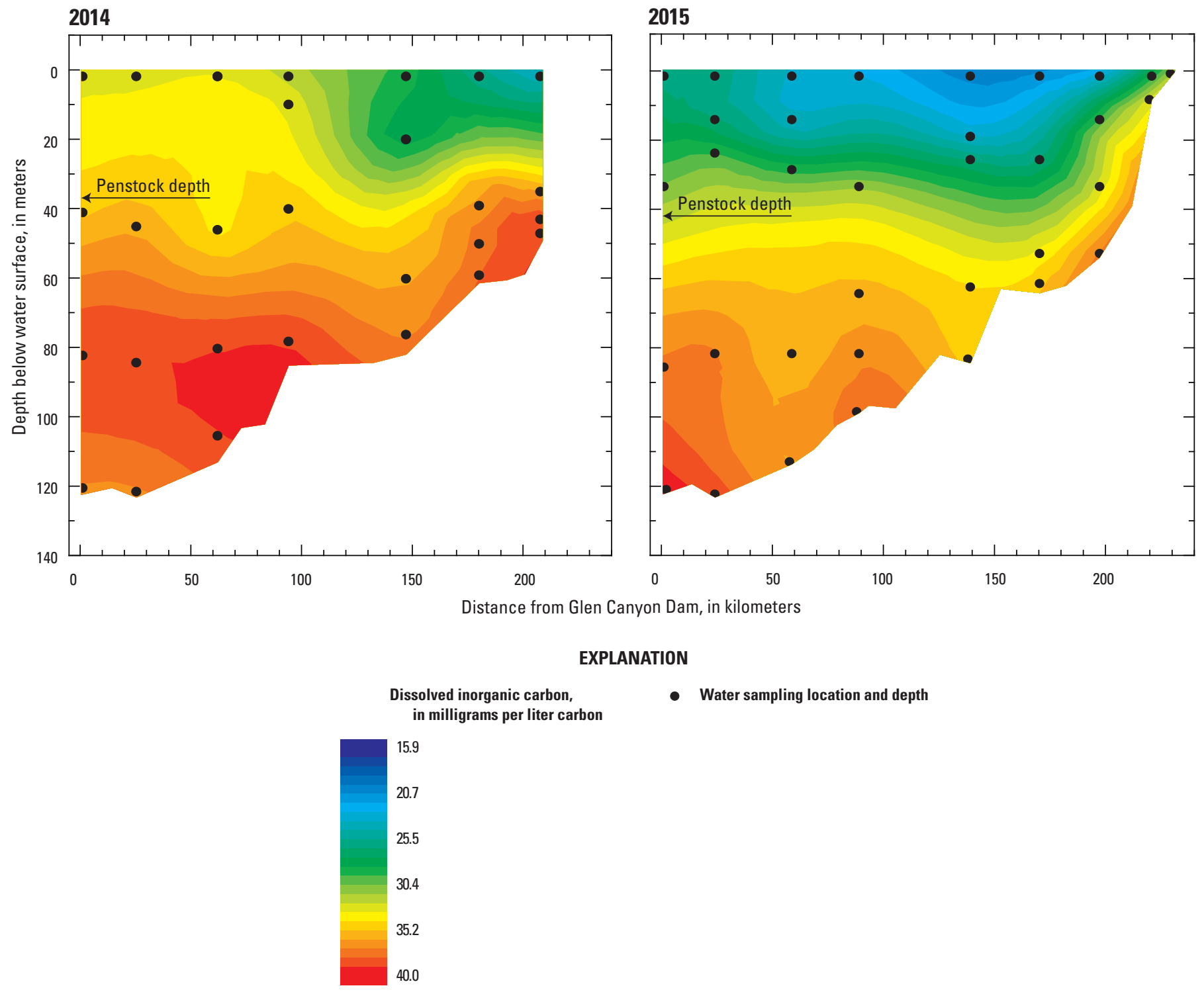

Figure 9. Distribution of dissolved inorganic carbon in the main stem of Lake Powell during the early-season (2014) and late-season (2015) synoptic sampling trips.

processes controlling $\mathrm{Hg}$ and associated chemical constituents. The location and depth of sites where water-quality and microbiological samples were collected also are shown in the profile results. Results for each field parameter from the earlyversus late-season synoptic sampling cruises are presented in this section.

Water temperature.-The $\mathrm{T}$ in the top $10 \mathrm{~m}$ within the main stem of Lake Powell was about 6 to $7{ }^{\circ} \mathrm{C}$ cooler during the early-season synoptic sampling cruise relative to the lateseason synoptic sampling cruise (fig. 10). The $\mathrm{T}$ in the deeper $(>50 \mathrm{~m})$ sections of the main reservoir channel remained less than $\sim 8^{\circ} \mathrm{C}$ during the late- and early-season synoptic sampling cruises. The slightly cooler water mass observed at site LP-15-I in the main stem during early- and late-season synoptic sampling cruises is likely affected by cooler water inflow from the San Juan River to the San Juan Arm of Lake Powell, entering directly upstream (fig. 10).

Specific conductance.-Early- versus late-season profiles of SC in the main stem differ substantially. The early-season SC profile in the main stem exhibited a near-surface, lower salinity plume in the upper one-third of the reservoir from about 130 to $210 \mathrm{~km}$ above Glen Canyon Dam. This earlyseason, low salinity plume ranged from 10 to $40 \mathrm{~m}$ in thickness (fig. 11). During the late-season synoptic sampling, the near-surface, low salinity plume in the main stem migrated to within about $30 \mathrm{~km}$ of Glen Canyon Dam, and the distal end of this plume was overlain by a higher salinity wedge of water about $10 \mathrm{~m}$ in thickness (fig. 11). The upper onehalf of the main stem of Lake Powell during the late-season synoptic sampling had a higher salinity ( $\sim 650$ microsiemens 


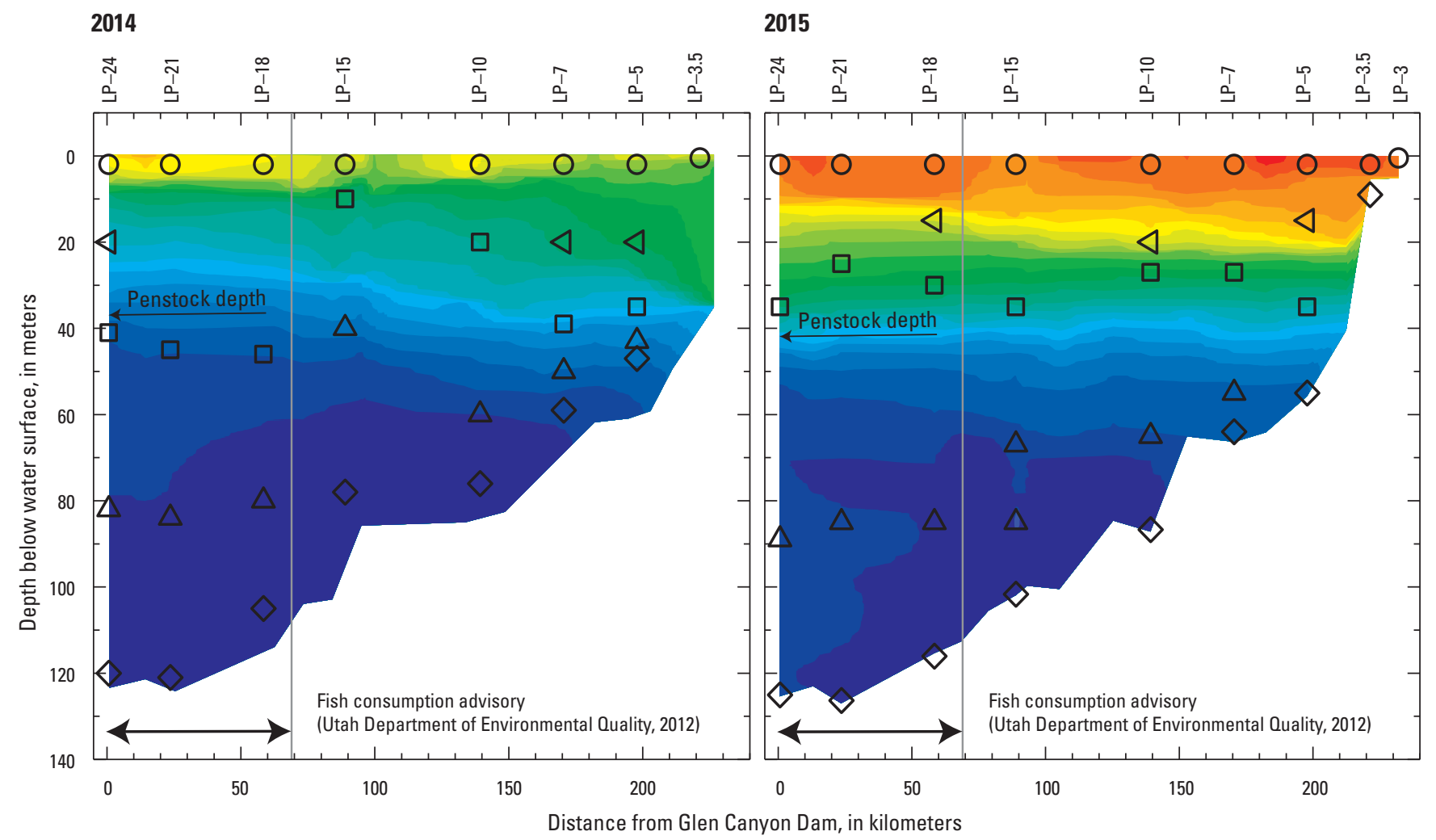

\section{EXPLANATION}

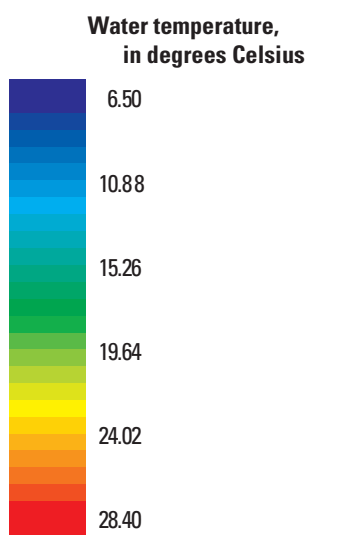

Location of water-quality samples

SRF-Water sample typically collected 2 meters below the water surface

$\checkmark$ EPI-Water sample typically collected from the middle of the epilimnion

$\square$ THM - Water sample collected from the middle of the thermocline

$\triangle$ MHY - Water sample collected from the middle of the hypolimnion

$\checkmark$ B2-Water sample collected 2 meters above the reservoir bottom

Figure 10. Comparison of water temperature profiles in the main stem of Lake Powell during the May/June 2014 and August 2015 synoptic sampling trips to the location of the fish consumption advisory, Glen Canyon National Recreation Area, Arizona and Utah.

per centimeter $[\mu \mathrm{S} / \mathrm{cm}])$ plume that had lower salinity lenses above and below it (fig. 11). In the main stem at distances $>210 \mathrm{~km}$ from the dam, a high salinity plume $(\sim 1,000 \mu \mathrm{S} / \mathrm{cm})$ was present during the late-season synoptic sampling. The zone of higher salinity water $(\sim 950$ to $1,000 \mu \mathrm{S} / \mathrm{cm})$ within 50 to $70 \mathrm{~km}$ of Glen Canyon Dam and generally below $80 \mathrm{~m}$ in depth was persistent during the early- and late-season synoptic sampling trips within the main stem. The volume and salinity of this zone are diminished during the late-season synoptic sampling cruise.
Overall, SC profiles in the river arm/side canyon/embayment sites are similar to the main stem profiles during the early- and late-season synoptic sampling trips (fig. 11). During the early-season synoptic sampling trip, lower salinity (400 to $500 \mu \mathrm{S} / \mathrm{cm}$ ) water was observed in the upper $5 \mathrm{~m}$ of the water column in the San Juan Arm (LP-1-I). During the late-season synoptic sampling trip, the San Juan and Escalante Arms exhibited lower salinity ( 360 to $500 \mu \mathrm{S} / \mathrm{cm}$ ) water in the upper $20 \mathrm{~m}$ of the water column. 


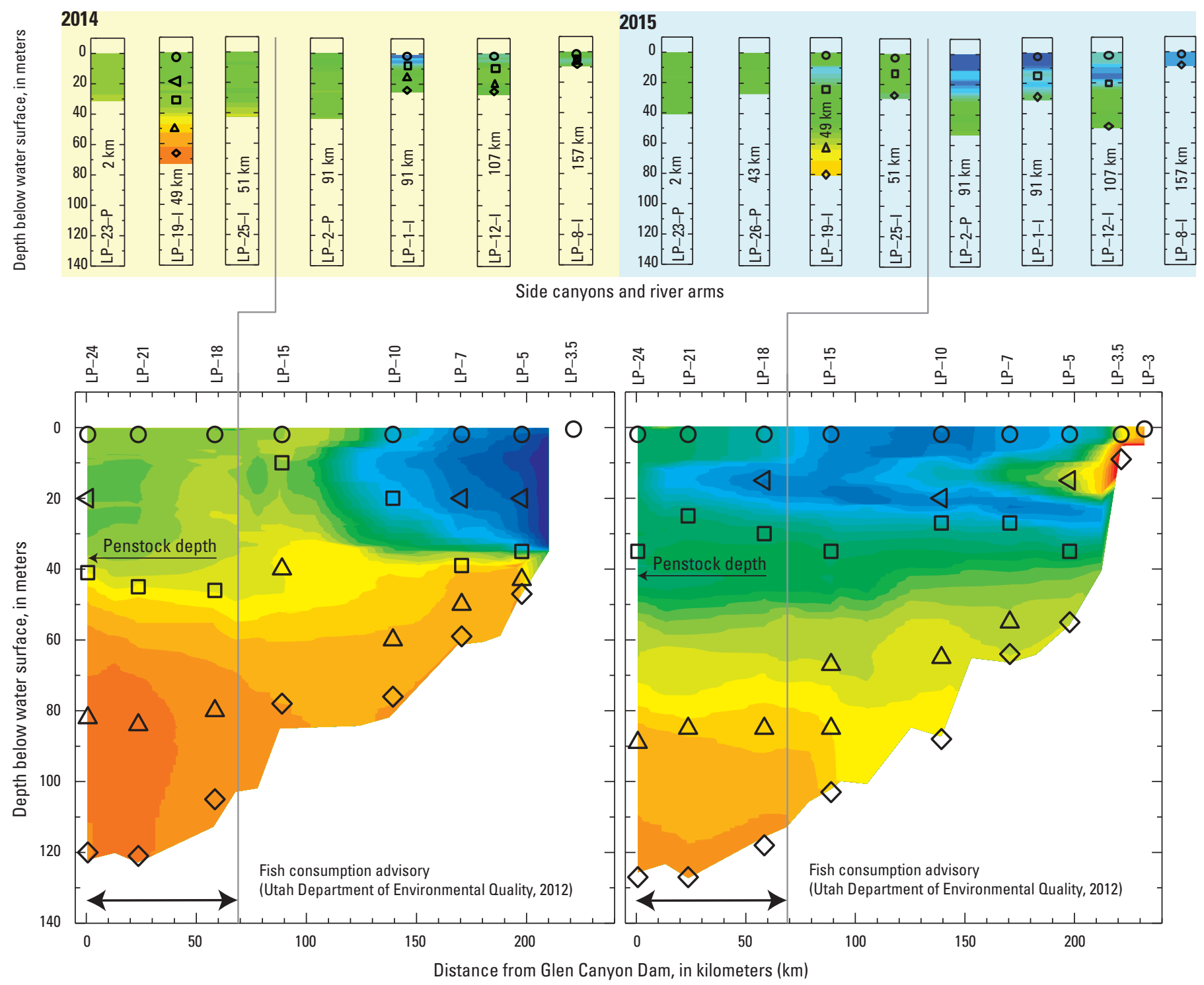

EXPLANATION

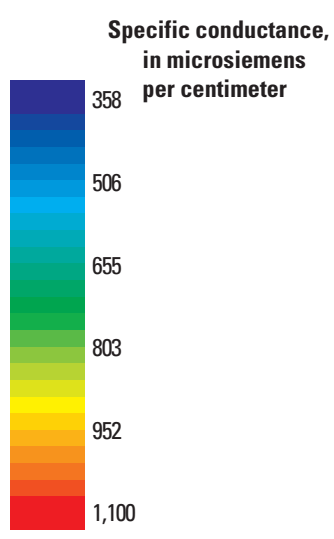

Location of water-quality samples

SRF-Water sample typically collected 2 meters below the water surface

$\checkmark$ EPI-Water sample typically collected from the middle of the epilimnion

$\square$ THM-Water sample collected from the middle of the thermocline

$\triangle$ МнY-Water sample collected from the middle of the hypolimnion

$\checkmark$ B2-Water sample collected 2 meters above the reservoir bottom

Figure 11. Comparison of specific conductance profiles in the main stem, river arms, side canyons, and embayments of Lake Powell during the May/June 2014 and August 2015 synoptic sampling trips to the location of the fish consumption advisory, Glen Canyon National Recreation Area, Arizona and Utah. 
Dissolved oxygen.--During the early season, no regions in the main stem of Lake Powell contained DO values less than $\sim 40$ percent saturation (fig. 12). In addition, near-surface areas of the water column $(<20 \mathrm{~m}$ depth) in the lower one-half of the reservoir at distances of 0 to $140 \mathrm{~km}$ from Glen Canyon Dam contained water with DO values $\geq 100$ percent saturation. In contrast, the late-season synoptic sampling completed during 2015 contained numerous areas with lower DO values $(<40$ percent saturation) in the main stem (fig. 12). Areas with lower DO included (1) water 0 to $40 \mathrm{~m}$ above the reservoir bottom from Glen Canyon Dam to $90 \mathrm{~km}$ above the dam; (2) water 0 to $2 \mathrm{~m}$ above the reservoir bottom in the upper areas of the reservoir, $>200 \mathrm{~km}$ from the dam; and (3) a layer of water about $20 \mathrm{~m}$ below the surface and extending from the upper part of the reservoir to $50 \mathrm{~km}$ above the dam (fig. 12). The third type of area coincides with the approximate boundary of the thin $(5 \mathrm{~m})$ low salinity layer directly beneath a thicker and higher salinity layer extending from 30 to $200 \mathrm{~km}$ from Glen Canyon Dam.

DO profiles in selected river arm/side canyon/embayment sites were lower than the main stem profiles during both synoptic sampling cruises (fig. 12). Site LP-25-I, in a side canyon with its mouth about $46 \mathrm{~km}$ from Glen Canyon Dam, was the only area during the early-season synoptic sampling cruise to exhibit DO saturation values $<10$ percent. Additional areas with DO saturation values $<10$ percent were observed during the late-season synoptic sampling cruise and included two side canyons (LP-26-P and LP-25-I) and the Escalante (LP-12-I) and San Juan (LP-1-I and LP-2-P) arms (fig. 12).

pH.-During the early-season synoptic sampling cruise, areas with the highest $\mathrm{pH}$ ( $\geq 8.1$ units) were constrained to the upper 10 to $20 \mathrm{~m}$ of the water column from 0 to $130 \mathrm{~km}$ in the main stem above Glen Canyon Dam (fig. 13). This area of elevated $\mathrm{pH}$ coincides with areas of elevated DO exceeding 100 percent saturation (fig. 12) and is consistent with the zone of optimal phytoplankton production, which tends to increase $\mathrm{pH}$. During the late-season synoptic sampling cruise, areas of the water column with elevated $\mathrm{pH}$ values ( $>8.1$ units) in the main stem expand to the reservoir length in the upper $10 \mathrm{~m}$ of the water column and also correspond to the areas with the highest DO saturation, ranging from $\sim 80$ to $>100$ percent (fig. 12). Areas of the water column with lower ( $<7.6$ units) $\mathrm{pH}$ values are isolated to two small areas in the main stem during the early-season synoptic sampling cruise $(20$ to $65 \mathrm{~km}$ and 170 to $190 \mathrm{~km}$ above the dam) and coincide with areas exhibiting the lowest percent saturation of DO (fig. 12). In contrast, the late-season synoptic sampling cruise identified two main areas of low $\mathrm{pH}(\leq 7.6$ units) in the main stem: (1) areas along the reservoir bottom to $60 \mathrm{~m}$ above the bottom and 20 to $200 \mathrm{~km}$ from the dam and (2) 10 to $30 \mathrm{~m}$ below the water surface about 40 to $160 \mathrm{~km}$ from the dam. Both of these areas also coincided with areas exhibiting low $(<35)$ percent saturation of DO (fig. 12).
Turbidity.-Because of the large range in TURB values (from 1 to 1,000 nephelometric turbidity units [NTUs]), a $\log 10$ scale was used to better visualize and compare the trends within the reservoir and between the early- and latesynoptic sampling cruises (fig. 14). During the early-synoptic sampling cruise, a large, elevated TURB (10 to 50 NTUs) plume was in the upper part of the reservoir from 120 to $210 \mathrm{~km}$ in the main stem above Glen Canyon Dam. From 120 to $150 \mathrm{~km}$ from the dam, the elevated TURB plume is only at depths below $\sim 10 \mathrm{~m}$ in the water column (fig. 14). At the point where the TURB plume is below the water surface, there is a distinct increase in the percent saturation of DO in the near surface of the water column that persists in the main stem all the way to Glen Canyon Dam. With the exception of the uppermost part of the reservoir main stem $(215$ to $230 \mathrm{~km}$ above the dam), there is no expression of a TURB plume at the reservoir surface during the late-season synoptic sampling cruise (fig. 14). An elevated TURB plume was at depth in the main stem during the late-season synoptic sampling cruise and extended to about $140 \mathrm{~km}$ above Glen Canyon Dam. At distances $<140 \mathrm{~km}$ from the dam, TURB values in the water column were generally less than 1.5 NTUs.

Fluorescent dissolved organic matter.-The raw fDOM signal from water-quality sondes such as the EXO 2 can be diminished by attenuation from suspended particles (Saraceno and others, 2017). Laboratory and site-specific correction methods have been developed to correct raw fDOM signals from suspended particles and other interferences including $\mathrm{T}$ and light attenuation from dissolved substances (Downing and others, 2012). Correction methods were not applied to the fDOM measurements collected during the synoptic sampling cruises. Instead, the contour line indicating elevated TURB ( $\geq 6$ NTUs) during the early- and late-season synoptic sampling cruises was superimposed on the contoured fDOM cross sections to provide a qualitative indication of where the fDOM signals may be diminished because of higher concentrations of suspended particulates (fig. 15).

During the early-season synoptic sampling cruise, the highest values of fDOM (ranging from about 10 to 15 relative fluorescence units [RFUs]) in the main stem are in the upper one-half of the reservoir, extending down reservoir to about $70 \mathrm{~km}$ above Glen Canyon Dam (fig. 15). This fDOM plume in the main stem is in the upper $40 \mathrm{~m}$ of the water column and is overlain by water with low fDOM values ( 0 to 3 RFUs) beginning about $125 \mathrm{~km}$ above the dam. The lens of low fDOM water that is continuous in the main stem from $125 \mathrm{~km}$ to the Glen Canyon Dam coincides with areas exhibiting DO concentrations exceeding 100 percent saturation. Finally, much of the water column with elevated fDOM values in the upper one-third of the reservoir also is coincident with elevated TURB, indicating that the actual fDOM values may be higher than measured and are depressed because of particle attenuation. 


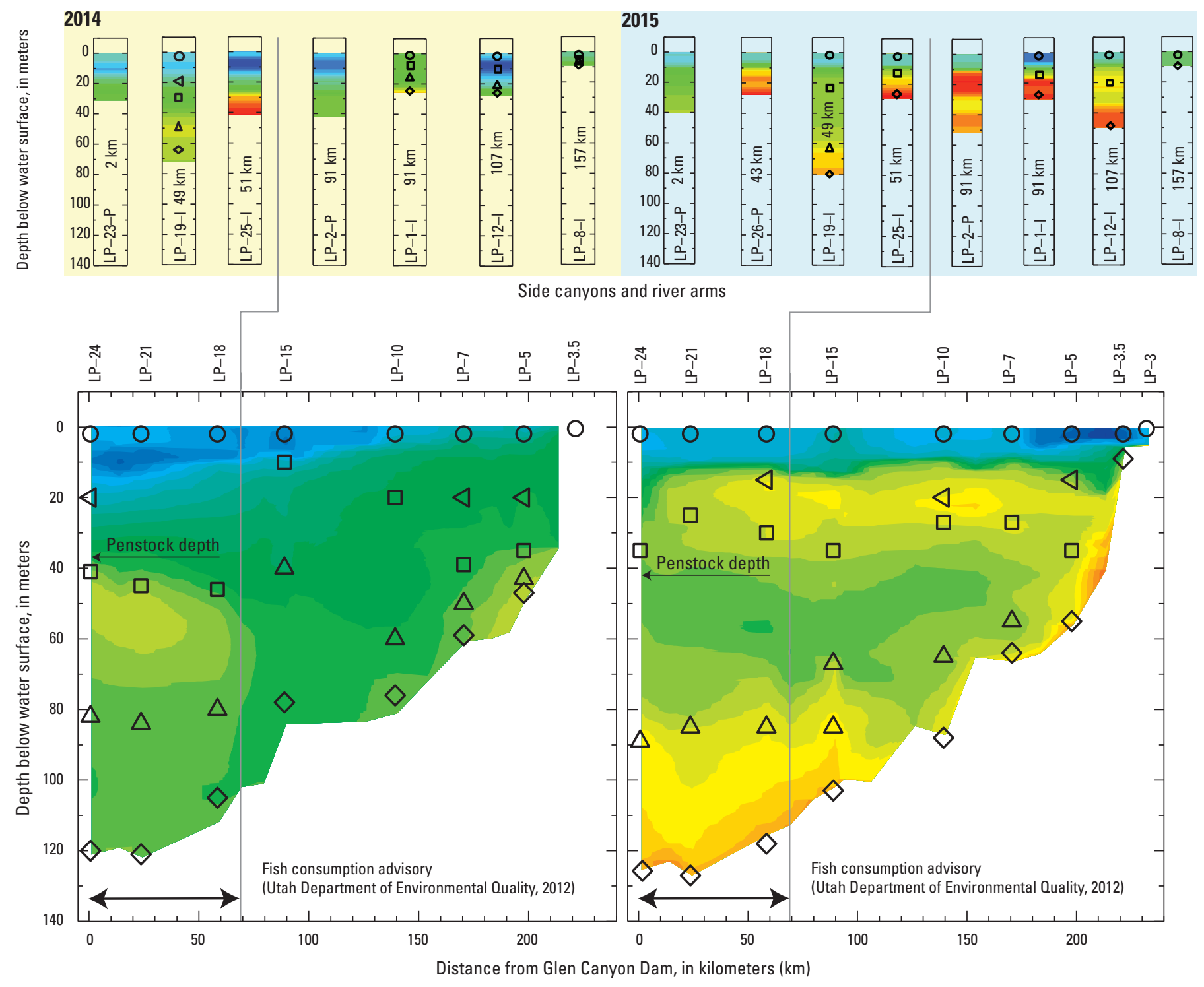

\section{EXPLANATION}

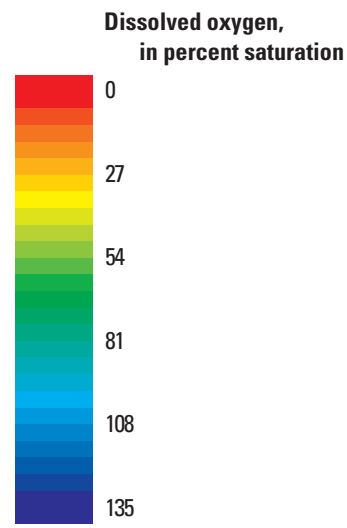

Location of water-quality samples

ORF - Water sample typically collected 2 meters below the water surface

$\triangle$ EPI-Water sample typically collected from the middle of the epilimnion

$\square$ THM-Water sample collected from the middle of the thermocline

$\triangle$ MHY - Water sample collected from the middle of the hypolimnion

$\diamond$ B2-Water sample collected 2 meters above the reservoir bottom

Figure 12. Comparison of dissolved oxygen, in percent saturation, profiles in the main stem, river arms, side canyons, and embayments of Lake Powell during the May/June 2014 and August 2015 synoptic sampling trips to the location of the fish consumption advisory, Glen Canyon National Recreation Area, Arizona and Utah. 


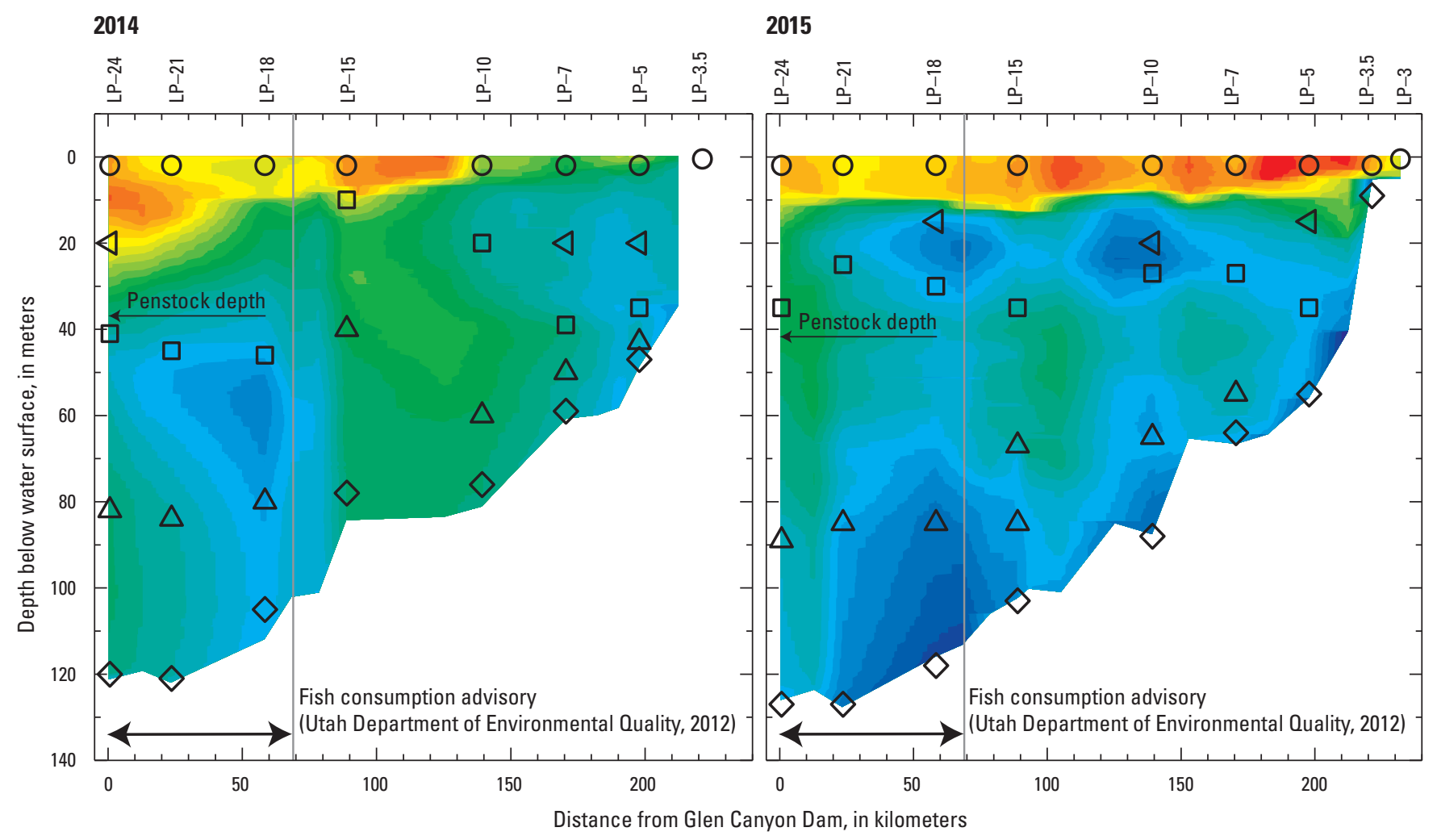

EXPLANATION

$\mathrm{pH}$, in units

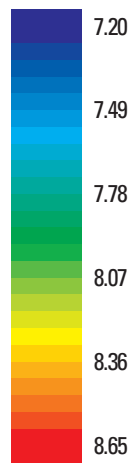

Location of water-quality samples

SRF-Water sample typically collected 2 meters below the water surface

$\checkmark$ EPI-Water sample typically collected from the middle of the epilimnion

$\square$ THM - Water sample collected from the middle of the thermocline

$\triangle$ MHY - Water sample collected from the middle of the hypolimnion

$\diamond$ B2-Water sample collected 2 meters above the reservoir bottom

Figure 13. Comparison of $\mathrm{pH}$ profiles in the main stem of Lake Powell during the May/June 2014 and August 2015 synoptic sampling trips to the location of the fish consumption advisory, Glen Canyon National Recreation Area, Arizona and Utah.

A much more pronounced and consistent plume of water containing fDOM values $>20$ RFUs is in the main stem during the late-season synoptic sampling cruise during 2015 (fig. 15). This high fDOM plume extends from 220 to about $15 \mathrm{~km}$ above Glen Canyon Dam. The base of this plume ranges from about $40 \mathrm{~m}$ in depth in the upper part of the reservoir to about $20 \mathrm{~m}$ in depth near the dam (fig. 15). The high fDOM plume seems unaffected by the region of high TURB water ( $\geq 6$ NTUs) in the upper reaches of the main stem and roughly coincides with a consistent region of low DO extending from the upper part of the reservoir main stem to $50 \mathrm{~km}$ above the dam, at a depth of about $20 \mathrm{~m}$ below the water surface. The region of the reservoir exhibiting the lowest fDOM values ( $\leq 3$ RFUs) was constrained to an area from 0 to $70 \mathrm{~km}$ above the dam and 0 to $10 \mathrm{~m}$ in depth from the surface, roughly coinciding with a region where DO concentrations are at or near 100 percent saturation (fig. 12).

In general, the two river arms reflect a similar vertical distribution of fDOM values as the main stem. The San Juan Arm (LP-2-P and LP-1-I) exhibits large fDOM values about 


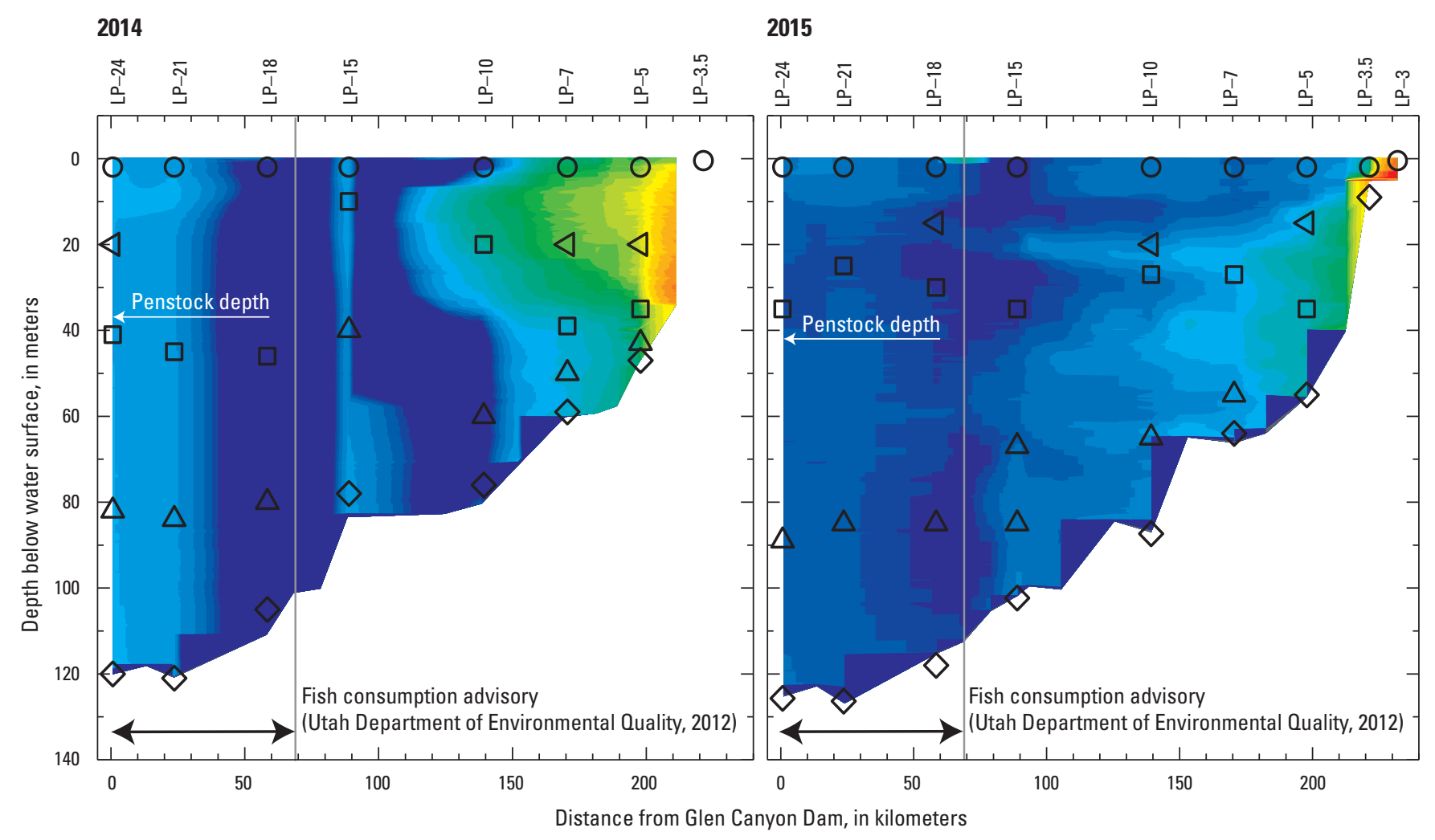

\section{EXPLANATION}

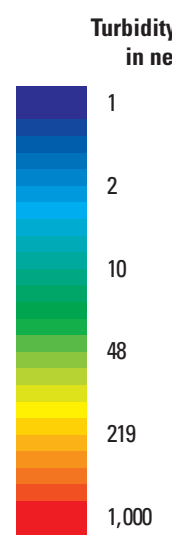

Location of water-quality samples

SRF-Water sample typically collected 2 meters below the water surface

$\checkmark$ EPI-Water sample typically collected from the middle of the epilimnion

$\square$ THM - Water sample collected from the middle of the thermocline

$\triangle$ MHY - Water sample collected from the middle of the hypolimnion

$\diamond$ B2-Water sample collected 2 meters above the reservoir bottom

Figure 14. Comparison of turbidity profiles in the main stem of Lake Powell during the May/June 2014 and August 2015 synoptic sampling trips to the location of the fish consumption advisory, Glen Canyon National Recreation Area, Arizona and Utah.

$20 \mathrm{~m}$ below the water surface, similar to the fDOM distribution in the main stem just downstream from the San Juan Arm (LP-15-I) (fig. 15). The Escalante Arm (LP-12-I) also exhibits an increase in fDOM values about $20 \mathrm{~m}$ below the water surface and at a similar depth where fDOM values are elevated in the main stem. The San Juan and Escalante Arms exhibit depressed DO concentrations in close proximity to the areas of elevated fDOM values.
Chlorophyll a.-The raw, in vivo chl.a concentrations (in relative fluorescence units) measured by the EXO 2 waterquality sonde were converted to chl.a concentrations (in micrograms per liter) by developing multiple linear regression (MLR) equations using a subset of samples where chl.a concentrations were determined by in vivo and wet chemistry methods (Welschmeyer, 1994). Turbidity was included in the MLR because of the potential interference of particulates when measuring in vivo chl.a (Turner Designs, Inc., 2018). 


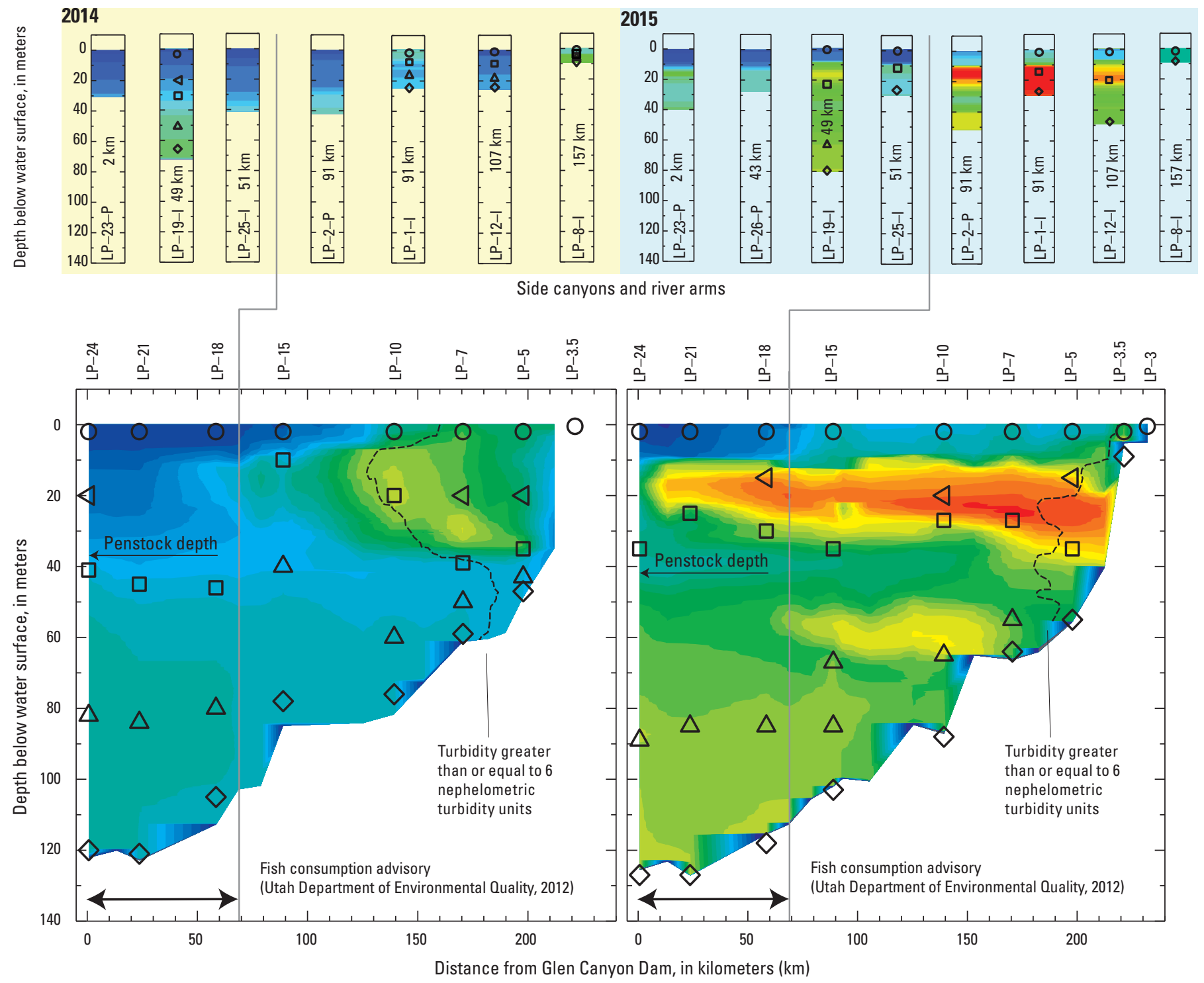

EXPLANATION

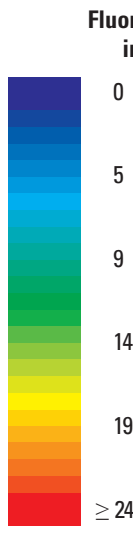

Location of water-quality samples

(n) organic matt

O SRF-Water sample typically collected 2 meters below the water surface

$\checkmark$ EPI-Water sample typically collected from the middle of the epilimnion

$\square$ THM - Water sample collected from the middle of the thermocline

$\triangle$ MHY - Water sample collected from the middle of the hypolimnion

$\checkmark$ B2-Water sample collected 2 meters above the reservoir bottom

24

Figure 15. Comparison of fluorescent dissolved organic matter profiles in the main stem, river arms, side canyons, and embayments of Lake Powell during the May/June 2014 and August 2015 synoptic sampling trips to the location of the fish consumption advisory, Glen Canyon National Recreation Area, Arizona and Utah. Dashed gray line indicates areas in the water column with elevated turbidity values in the upper part of the reservoir. 
The MLR equations used to convert in vivo chl.a measurements to an extracted chl.a concentration, in micrograms per liter, were:

Early-season synoptic sampling cruise (2014) chl. $a=$ $(2.57552 * I N V$ chl.a $)+(0.00601 *$ TURB $)+0.01389$

Late-season synoptic sampling cruise (2015) chl. $a=$ $(4.94131 * I N$ Chl.a $)+(0.01339 *$ TURB $)+0.7439$

where

INVchl.a, is the in vivo chlorophyll $a$ value, in relative fluorescence units; and

$T U R B, \quad$ is the turbidity concentration, in nephelometric turbidity units.
MLR statistics include early-season synoptic ( $n=31$, coefficient of determination $\left.\left[R^{2}\right]=0.80471, p<0.0001\right)$ and lateseason synoptic $\left(n=47, R^{2}=0.91293, p<0.0001\right)$ results.

One region of elevated chl.a concentrations ( 4 to $5 \mu \mathrm{g} / \mathrm{L}$ ) extending up reservoir in the main stem from the dam for $100 \mathrm{~km}$ was observed during the early-season synoptic sampling (fig. 16). This high chl.a zone was about $4 \mathrm{~m}$ thick and about 5 to $10 \mathrm{~m}$ below the reservoir surface, roughly corresponding to an area of high DO saturation, consistent with a zone of active primary production. The slightly elevated $(\sim 4 \mu \mathrm{g} / \mathrm{L})$ concentrations of chl.a in a small $(<10 \mathrm{~km})$ region of the main stem transect at the upper end of Lake Powell, between sites LP-5 and LP-3.5, were likely an artifact from the high TURB concentrations measured during the earlyseason synoptic sampling cruise (fig. 14).

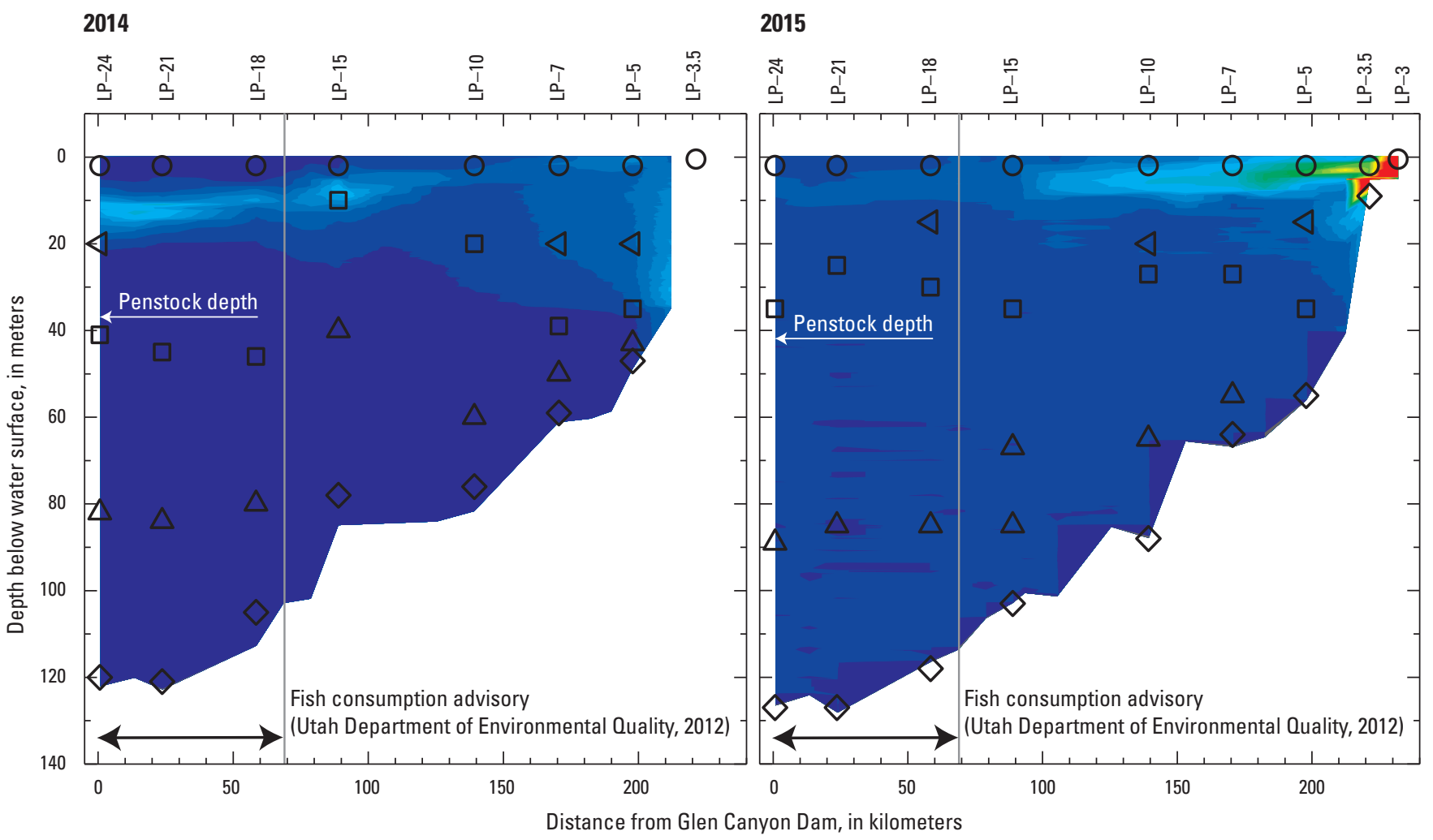

EXPLANATION

Figure 16. Comparison of chlorophyll a profiles in the main stem of Lake Powell during the May/June 2014 and August 2015 synoptic sampling trips to the location of the fish consumption Chlorophyll $a$, in micrograms per liter

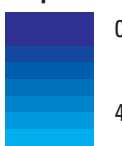

advisory, Glen Canyon National

Recreation Area, Arizona and Utah.
Location of water-quality samples

O SRF-Water sample typically collected 2 meters below the water surface

$\checkmark$ EPI-Water sample typically collected from the middle of the epilimnion

$\square$ THM - Water sample collected from the middle of the thermocline

$\triangle$ MHY - Water sample collected from the middle of the hypolimnion

$\checkmark$ B2-Water sample collected 2 meters above the reservoir bottom 
During the late-season synoptic sampling cruise, elevated chl.a concentrations ( $\sim 4$ to $20 \mu \mathrm{g} / \mathrm{L}$ ) were confined to the top $10 \mathrm{~m}$ of the water column in the main stem from 100 to 230 km above Glen Canyon Dam (fig. 16). During the earlyseason synoptic sampling cruise, this same region of the reservoir had elevated TURB concentrations; however, during the late-season synoptic sampling cruise, the near-surface TURB concentrations in the upper $130 \mathrm{~km}$ of the main stem were generally less than 3 NTUs (fig. 14). In addition, this area of the reservoir also contained DO concentrations that exceeded 100 percent saturation, consistent with a zone of active primary production.

\subsection{Biota}

Mercury and mercury isotopes.-Of the seven bulk plankton measurements, six were statistically different $(p<0.05)$ between the early-season and late-season sampling efforts (appendix 5). Among these parameters, LSM-modeled values were greater in the early season (relative to the late season) in all cases except for gravimetric bulk plankton total mercury concentration (bulk.THg.mass), which was slightly higher in the late season (43.61 versus $56.53 \mathrm{ng} / \mathrm{g}$ dry weight, respectively). Notable late-season decreases were measured for four parameters, with nearly three- to eight-fold decreases in plankton measurements observed for volumetric bulk plankton biomass (7.8), bulk plankton biomass (by weight) per total suspended sediment mass (by weight) (3.3), volumetric bulk plankton methylmercury concentration (bulk.MeHg.vol [6.2]), and volumetric bulk plankton total mercury concentration (bulk.THg.vol [4.8]).

Differences in plankton $\mathrm{Hg}$ metrics between the upper and lower sections of Lake Powell also were observed (fig. 17, appendix 5). Of particular note was the higher percent of methylmercury in bulk plankton in the upper reservoir during the early season. There is a general downstream increase in concentration in volumetric bulk plankton for mass/volume total mercury concentration in bulk plankton and mass/volume methylmercury concentration of bulk plankton, with relatively high concentrations measured about $50 \mathrm{~km}$ above Glen Canyon Dam in 2014. There is a modest increase in the mass/mass concentration of total mercury in bulk plankton, in nanograms per gram in 2014; however, this trend is not apparent in 2015. There is a substantial increase in gravimetric concentrations of the mass/mass concentration of methylmercury in bulk plankton, in nanograms per gram, and the mass/mass concentration of total mercury in bulk plankton, in nanograms per gram, about $90 \mathrm{~km}$ above Glen Canyon Dam in 2015. LSMmodeled, bulk plankton biomass was significantly $(p<0.05)$ higher in 2014, compared to 2015, for volumetric and gravimetric concentrations (appendix 5). Further, gravimetric bulk plankton biomass was significantly higher in the upper reservoir ( $2.42 \pm 0.73$ percent), compared to the lower reservoir $(0.78 \pm 0.19$ percent $)$, and in the early season $(2.48 \pm 0.82$ percent compared to the late season $(0.76 \pm 0.19$ percent $)$ (appendix 5). In contrast, a similar upper versus lower reservoir trend was not determined to be significant on a volumetric (in milligrams per liter) basis. There also was no significant difference in bulk plankton biomass concentrations between main stem and arm sites on a volumetric or gravimetric basis.

Only 2 out of 50 of the striped bass samples that were collected during 2014 (this study) contained tissue Hg concentrations at or above the human health criterion for $\mathrm{Hg}$ in fish (fig. $18 A$ ) of $0.3 \mathrm{mg} / \mathrm{kg}$ (wet weight, fish muscle) (U.S. Environmental Protection Agency, 2000). Striped bass were collected from three sites in Lake Powell: Good Hope Bay, San Juan Arm, and Wahweap Bay (fig. 3). Mean THg concentration in fish muscle tissue normalized to $420 \mathrm{~mm}$ exhibited the highest concentration in fish collected from the San Juan Arm and the smallest concentration in fish collected from Good Hope Bay.

Mercury isotopes in muscle tissue samples from striped bass that span the geographic range of our study were used to determine if the three populations sampled were isotopically distinct with respect to the geographic area (Good Hope Bay, Wahweap Bay, and San Juan Arm). A comparison of capital delta $(\Delta)^{199} \mathrm{Hg}$ and $\delta^{202} \mathrm{Hg}$ in the 50 tissue samples reveals that fish from the most downstream location (Wahweap Bay) were isotopically enriched in both isotopes $(p<0.05)$, relative to the populations from the two upstream sites (Good Hope Bay and San Juan Arm) (fig. 19). Further, the isotopic signatures were not significantly different between Good Hope Bay and San Juan Arm, indicating similar $\mathrm{Hg}$ sources for these two sites (appendix 6). It is notable that for the $\Delta^{199} \mathrm{Hg}$ versus $\delta^{202} \mathrm{Hg}$ plot (fig. 19), all the fish tissue data fall essentially along the same line, indicating that the relative change in both isotopic signals is constant and is indicative of differences in the extent of $\mathrm{MeHg}$ photodegradation in the water column (increasing with the degree of isotopic enrichment along both axes). Sediment from the same sites also plots along this same common line, whereas some sediment samples collected from other locations throughout the system seem more depleted in the $\delta^{202} \mathrm{Hg}$ signal. These results indicate that the extent of $\mathrm{MeHg}$ photodegradation is likely higher at the Wahweap Bay site, as compared to the generally more turbid upstream sites (Good Hope Bay and San Juan Arm).

$16 S$ rRNA gene templates.-Quantitative polymerase chain reaction was used to determine the abundances of 16S rRNA gene templates as a proxy for microbial biomass (archaea, bacteria, and chloroplast encoding eukarya) in filtered water samples collected at intensive sampling sites during the May/June 2014 and August 2015 synoptic sampling trips . A total of three areas with high concentrations of 16S rRNA genes were observed in waters collected from the same locations and water depths from both synoptic surveys. These include surface waters at the upper end of the reservoir and those collected near the dam at depths of 22 and $125 \mathrm{~m}$. In waters collected in May/June 2014, the abundances of $16 \mathrm{~S}$ rRNA genes were, on average, higher in samples collected from the surface and from deep waters than 

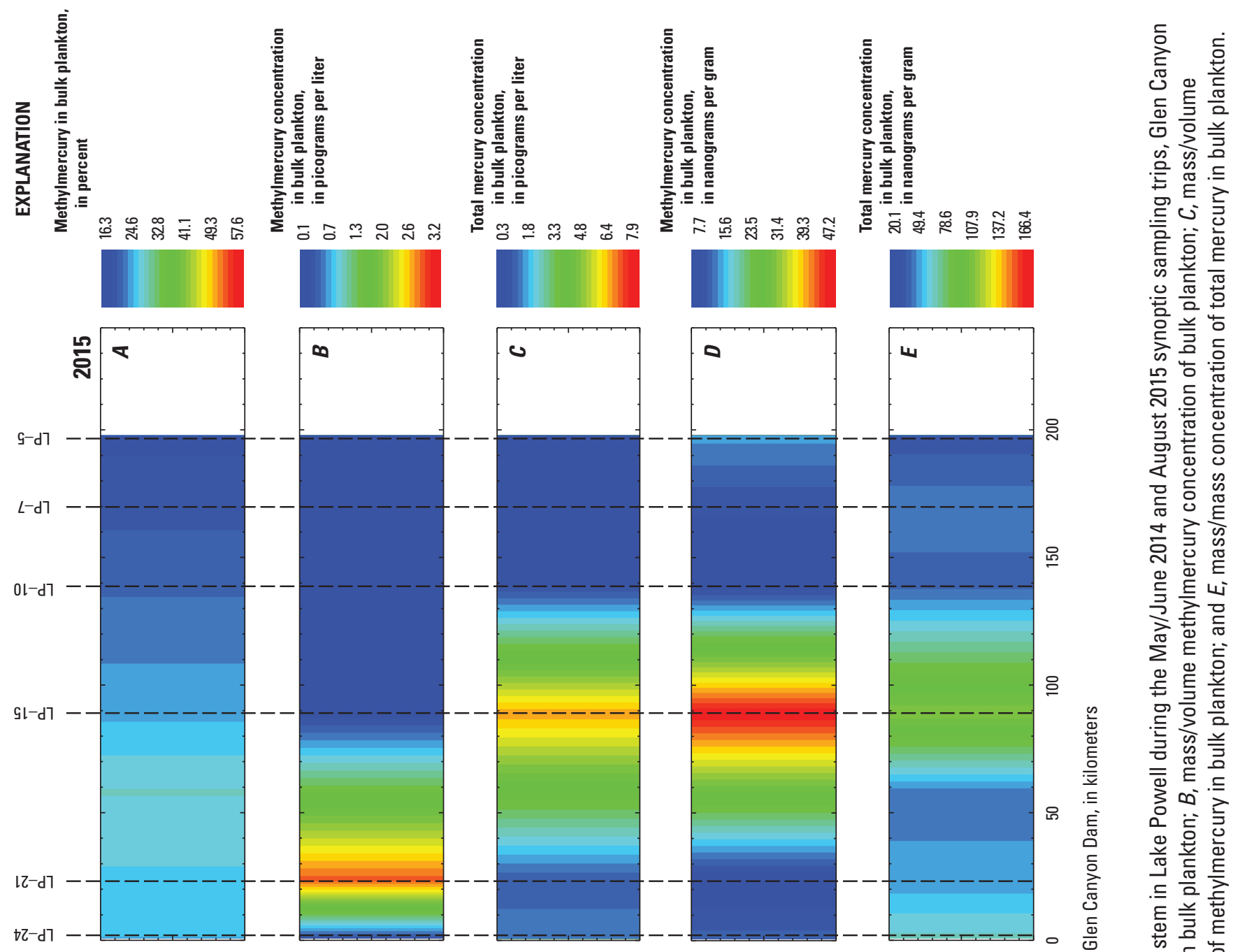

을 元

을 兰

的高

는 는

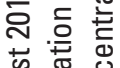

弯

월 인

它

它

오

ปิ

它出

곻들

$\sum_{\text {D }}^{\infty}$ 㝘

으

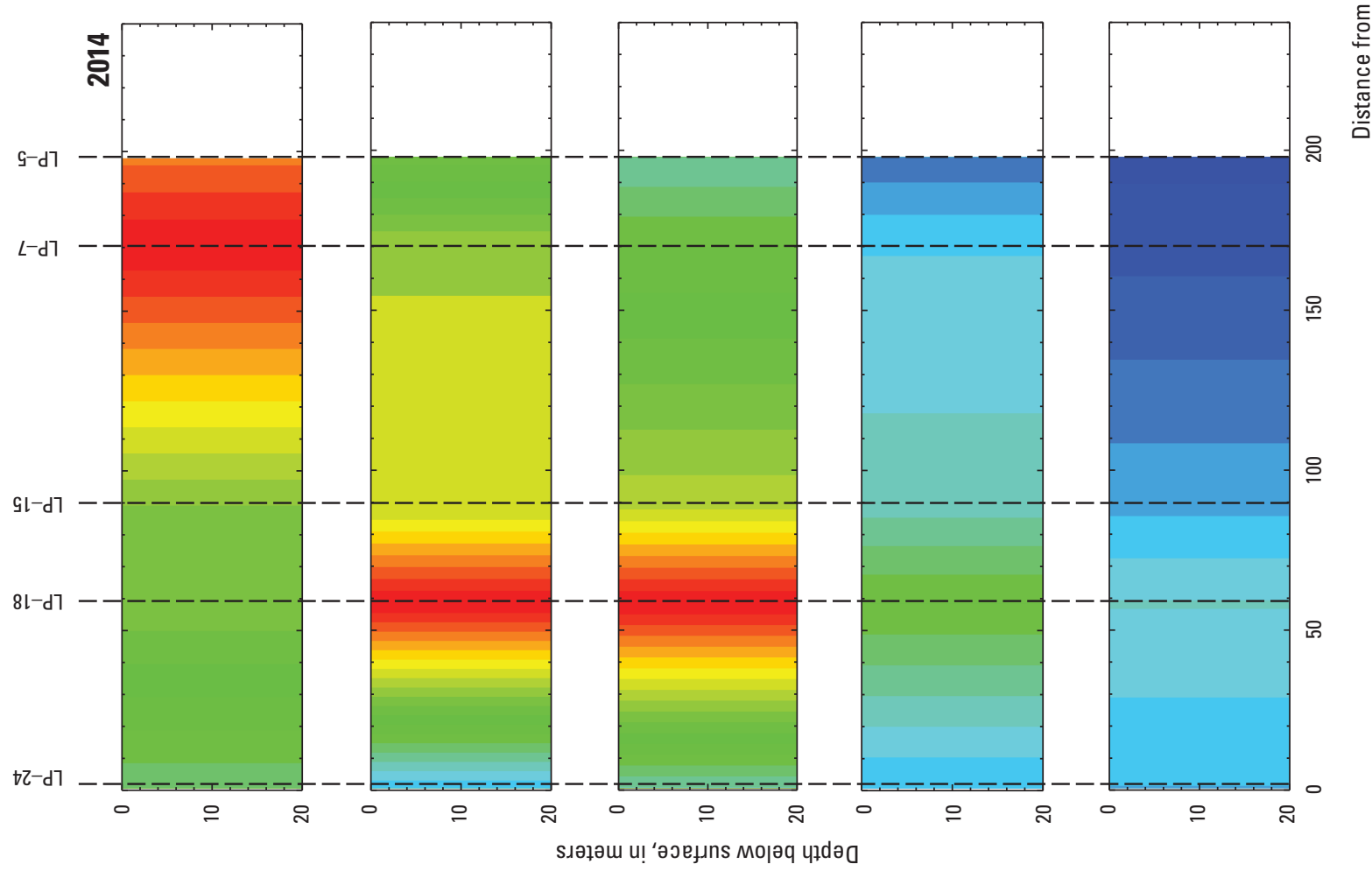

올울 즘

言离言

可

วั0

등

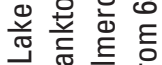

든 $\frac{\pi}{2}$

है

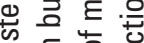

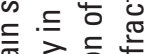

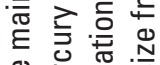

(2) $\frac{\pi}{5} \cdot \frac{N}{\omega}$

Е Ф

등

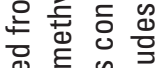

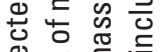

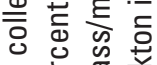

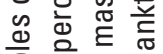

远京

密宅

$\subseteq$ 元

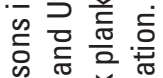

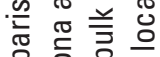

를.로음

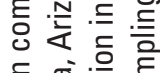

동 융

妾芒的

즘 더웡

羙苋

ص

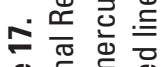

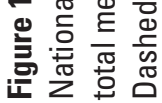



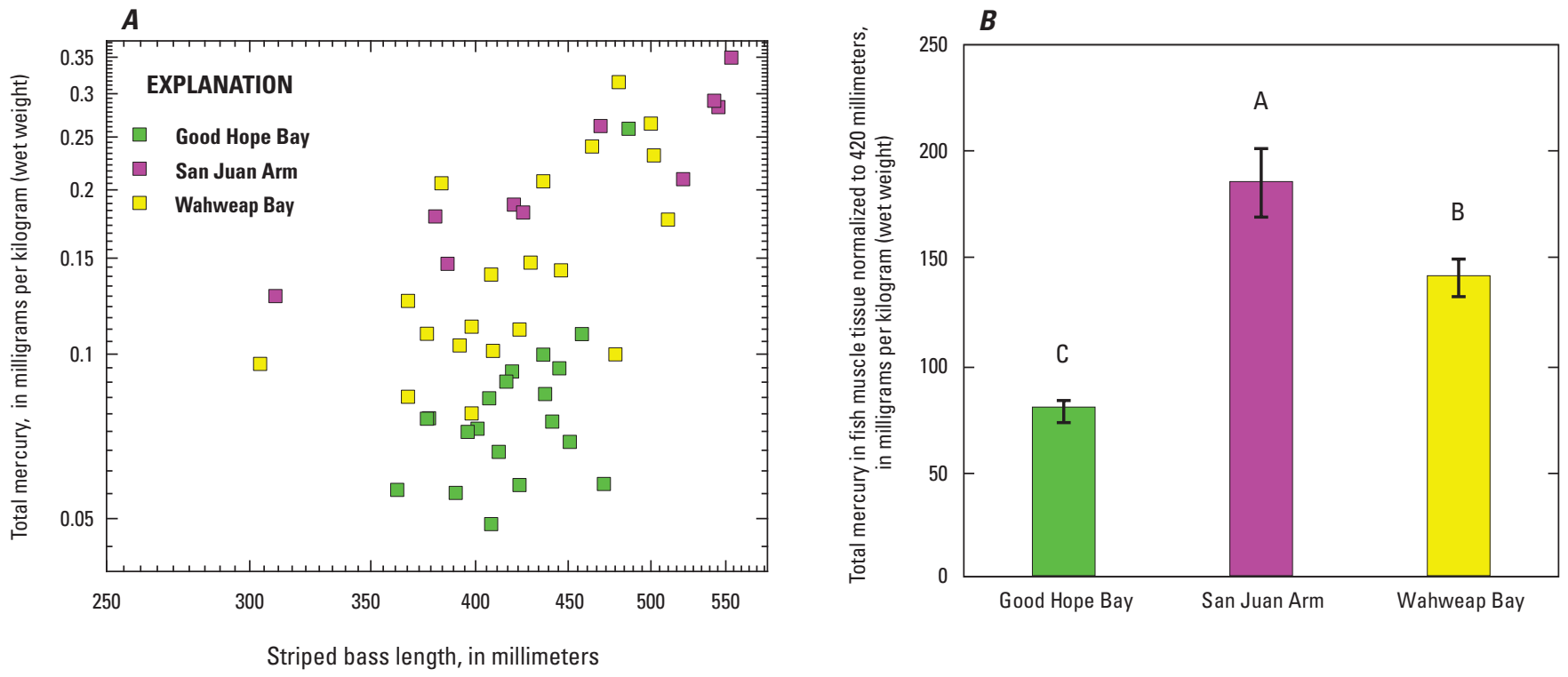

Figure 18. Results of the fish sampling completed during 2014 in Lake Powell. $A$, total mercury concentration in muscle tissue compared to fish length; and $B$, distribution of total mercury concentration in fish muscle tissue normalized to 420 millimeters in samples collected from Good Hope Bay, San Juan Arm, and Wahweap Bay. Modeled least square means for normalized fish muscle tissue from each of the three sites were significantly $(p<0.05)$ different, with San Juan Arm>Wahweap Bay>Good Hope Bay (appendix 6).

Figure 19. The delta ${ }^{202}$ mercury $\left(\delta^{202} \mathrm{Hg}\right)$ and capital delta ${ }^{199}$ mercury $\left(\Delta^{199} \mathrm{Hg}\right)$ isotopic composition in muscle tissue samples from striped bass and sediment samples collected from Lake Powell during 2014. Fish sampling locations are shown in figure 3 .

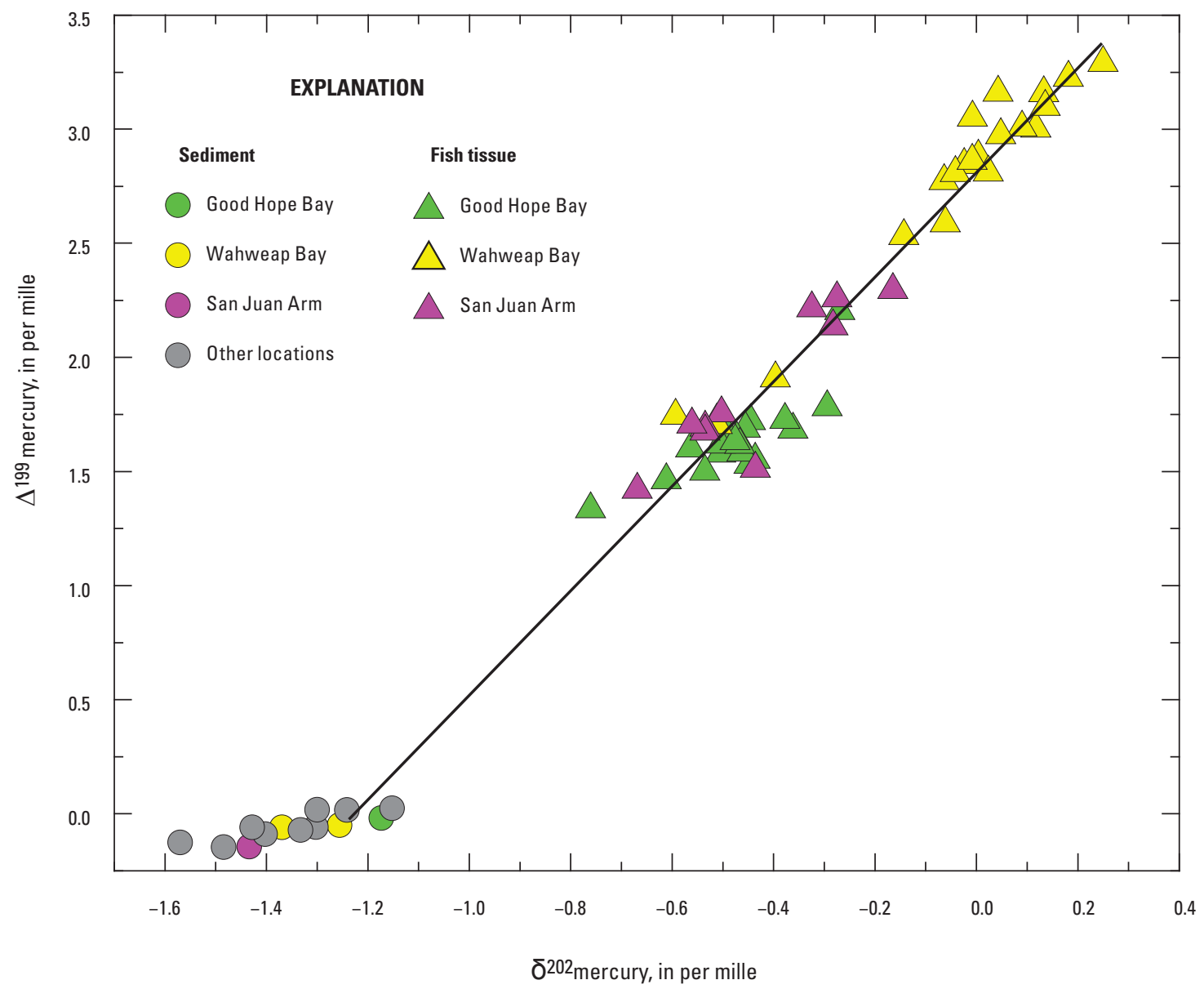


in samples collected from the thermocline and midhypolimnion; 16S rRNA gene abundances were, on average, higher in surface waters than in deep waters (fig. 20). The abundance of 16S rRNA genes was higher, on average, in samples collected from the upper reservoir (LP1-LP12) than those collected from the lower reservoir (LP15-LP24) regardless of the depth sampled (that is, surface, thermocline, midhypolimnion, and deep).

In contrast to waters collected in May/June 2014, the abundances of 16S rRNA genes in waters collected from August 2015 increased systematically on average with depth; the highest overall abundances were observed in deep samples collected near the dam (fig. 20). Also, in contrast to waters collected in May/June 2014, the abundance of 16S rRNA genes in waters collected in August 2015 was higher, on average, in samples collected from the lower reservoir (LP15-LP24) than in those collected from the upper reservoir (LP1-LP12) regardless of the depth sampled. It also is clear that there is an elevated zone of bacterial biomass just upstream from the dam in the deepest part of the water column (hypolimnion) during the August 2015 period (fig. 20).

A comparison of the abundances of 16S rRNA genes in samples collected in May/June 2014 and August 2015 indicates that templates in water-column samples from the upper reservoir were lower in 2015 than 2014, regardless of sampling depth (fig. 20). In contrast, templates in the lower reservoir were generally higher in 2015 than 2014, regardless of sampling depth. On average, the abundance of templates in all water-column samples collected in 2015 was moderately greater $(p<0.01)$ than in samples collected in 2014, when controlling for depth and upper versus lower reservoir (appendix 2).

\subsection{Sediment}

Total mercury.-A subset of the full suite of sediment parameters (Marvin-DiPasquale and others, 2017) is presented graphically as a function of distance upstream from the Glen Canyon Dam and briefly described. Sediment THg generally decreased along the Lake Powell main stem with distance upstream from the Glen Canyon Dam (fig. 21). There was a notable break in this trend at site LP-18, where THg was particularly low $(\sim 20 \mathrm{ng} / \mathrm{g})$ during 2014 relative to the sites immediately upstream (LP-15) and downstream (LP-21). However, when THg is normalized to sediment organic content (THg/LOI), this deviation largely disappears (fig. 22), indicating that much of the $\mathrm{THg}$ is associated with organic material buried in the sediment. There remains an approximate two-fold increase in $\mathrm{THg} / \mathrm{LOI}$ from the most upstream site (LP-3.ALT, $690 \mathrm{ng} / \mathrm{g}$ organic matter) to the most downstream site (LP-24, 1,530 ng/g organic matter) during 2014. This overall upstream to downstream increase in $\mathrm{THg}$ and $\mathrm{THg} / \mathrm{LOI}$ was more subtle but still apparent during the 2015 sampling event. When controlling for year, modeled LSM concentrations of THg was weakly significantly higher $(p=0.077)$ and $\mathrm{THg} / \mathrm{LOI}$ was significantly higher $(p=0.039)$, in the lower reservoir compared to the upper reservoir (appendix 4), although there were no significant differences between main stem and arm sites for these two parameters (appendix 3).

Reactive mercury.-Sediment RHg exhibited peak concentrations (1-2 ng/g dry weight) at the two most downstream main stem sites (LP-21 and LP-24) during 2014, a peak that essentially disappeared during the low-flow August 2015 period (fig. 23). In addition, there were elevated $\mathrm{RHg}$ concentrations in the San Juan Arm sample (LP-1) during 2014 and the LP-19 sample during 2015, both off the main stem of Lake Powell. When expressed in terms of a percentage of $\mathrm{THg}$, RHg was most elevated (9.1 percent of THg) in the San Juan Arm (LP-1) during 2014 (fig. 24) and was less than 3.3 percent of THg in all other samples (both sampling events). Modeled LSM concentrations of RHg were significantly $(p<0.1)$ higher in the early season compared to the late season, when controlling for spatial differences (appendixes 3 and 4), as were $\mathrm{RHg}$ concentrations normalized to organic content $(\mathrm{RHg} / \mathrm{LOI})(p<0.05)$. No significant differences were observed between main stem and river arm/side canyon/embayment sites (appendix 3) nor between upper and lower reservoir sites (appendix 4).

Methylmercury.-Sediment MeHg did not have a consistent trend along the length of the main stem of Lake Powell (fig. 25), although there was a general increase in concentration from the upper reservoir to the lower reservoir during 2014; the highest concentration was at LP-24, nearest the dam. During 2015, peak sediment MeHg concentration was measured at main stem site LP-18. Most of the river arm/ side canyon/embayment sites also exhibited elevated sediment $\mathrm{MeHg}$ concentration. $\mathrm{MeHg}$ as a percentage of $\mathrm{THg}$ $(\% . \mathrm{MeHg})$ fell within a fairly narrow range (from 0.2 to 2.7 percent) across all sites during 2014 (fig. 26). In contrast, the trend in \%.MeHg largely followed the trend in sediment MeHg concentration (fig. 25) during 2015. It is notable that the two West Canyon sites (LP-25A and -25B), which were collected $<1 \mathrm{~km}$ apart, nonetheless exhibited starkly different sediment $\mathrm{MeHg}$ concentrations (fig. 25 ) and \%.MeHg values (fig. 26); the deeper LP-25B site had the higher of the two values. This indicates a high degree of spatial heterogeneity can exist within the system at small spatial scales. Statisti$\mathrm{cal}$ analysis reveals higher \%.MeHg during the late season, compared to the early season, but no seasonal differences for sediment $\mathrm{MeHg}$ (or $\mathrm{MeHg} / \mathrm{LOI}$ ) concentration (appendix 4). There also were no significant differences between the main stem and river arm/side canyon/embayment sites (appendix 3) nor between the upper and lower reservoir sites (appendix 4). 


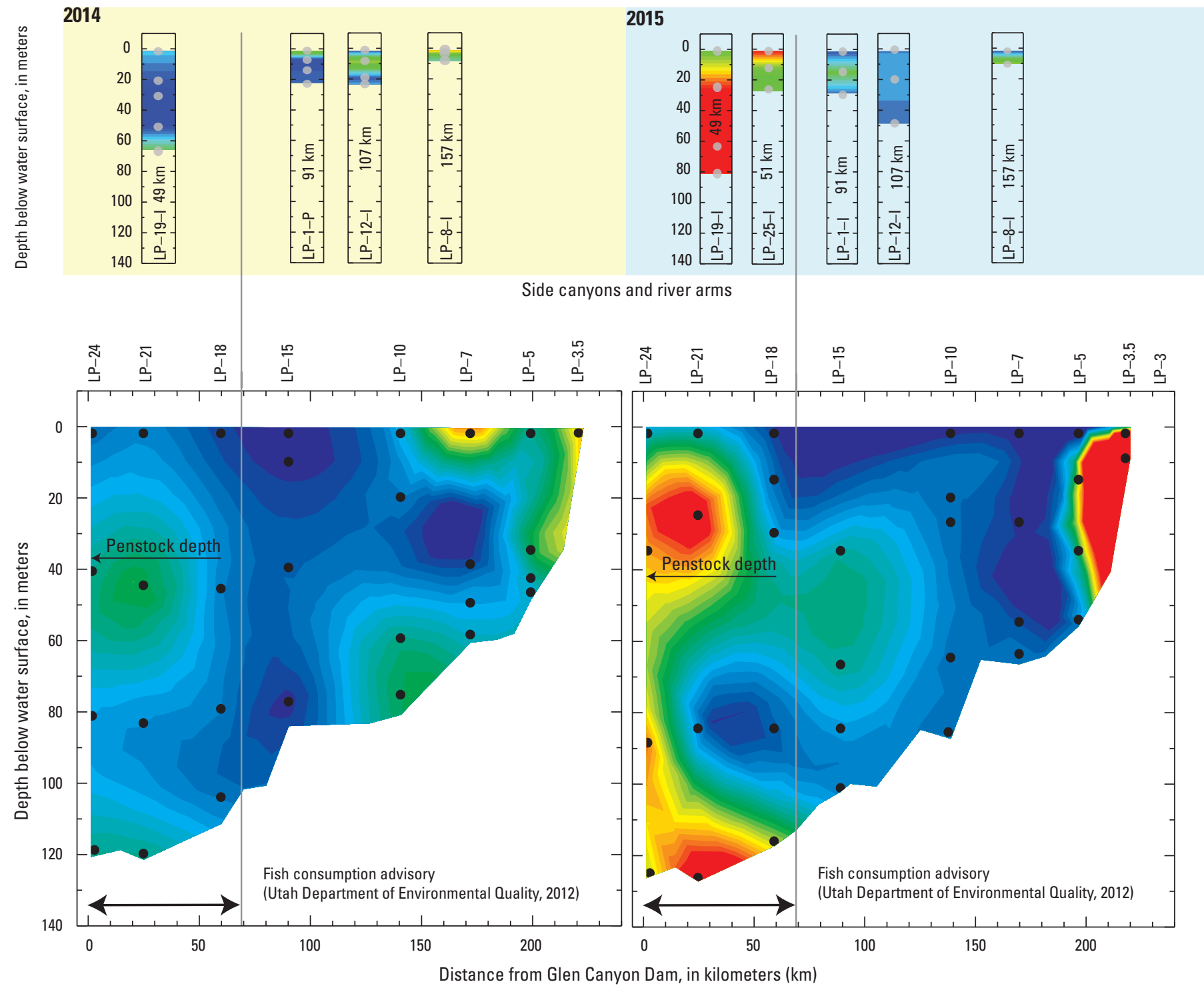

EXPLANATION

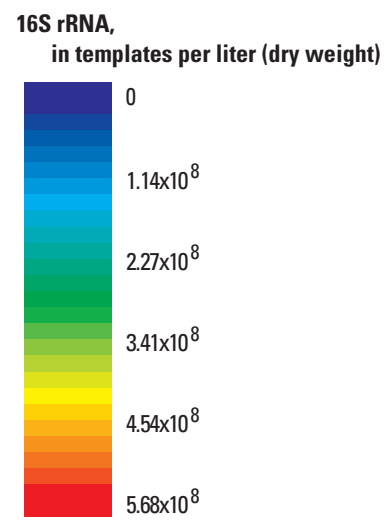

- Water sampling location and depth

Water sampling location and depth (side canyons and river arms)

Figure 20. Comparison of the abundance of ribosomal ribonucleic acid, small subunit 16 (16S rRNA) templates in the main stem, river arms, side canyons, and embayments within Lake Powell during the May/June 2014 and August 2015 synoptic sampling trips to the location of the fish consumption advisory, Glen Canyon National Recreation Area, Arizona and Utah. 
A. May/June 2014

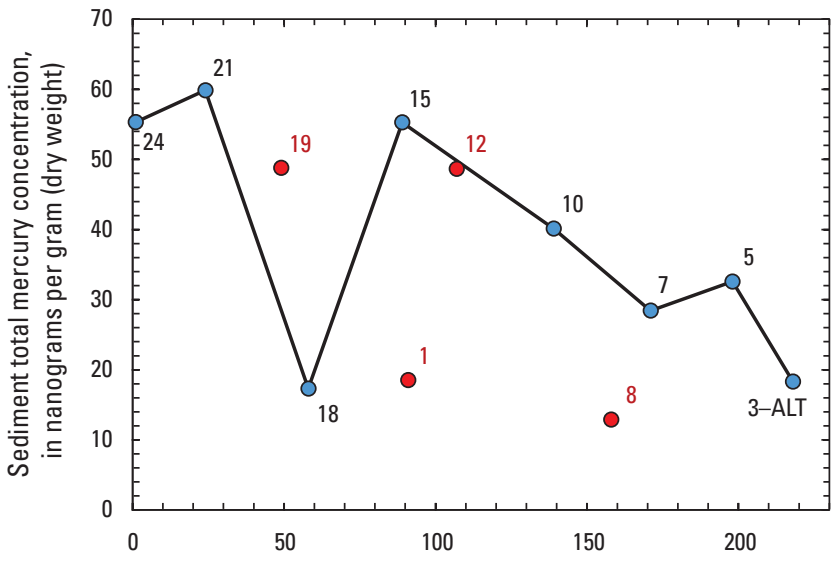

B. August 2015

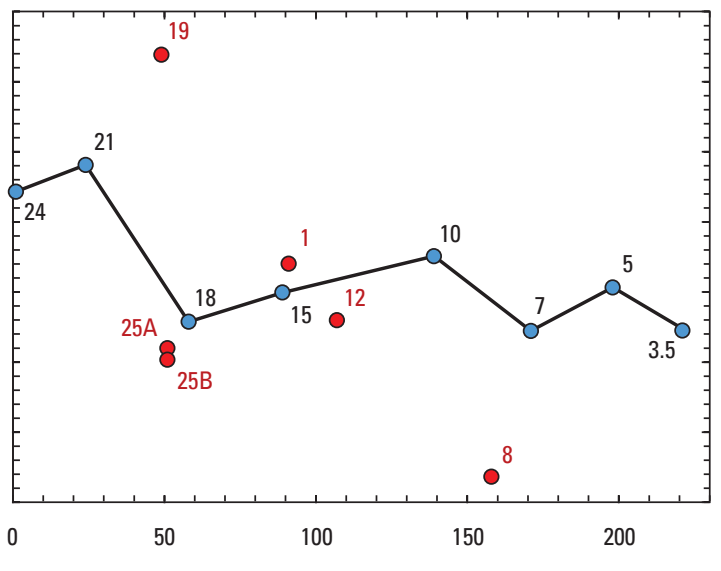

Distance from dam, in kilometers

EXPLANATION

Site along the main stem

- Site not within the main stem-Symbols are plotted as a function

of the distance where the mouth of that incoming arm (river arm,

side canyon, or embayment) intersects with the main stem

Figure 21. Sediment total mercury concentration as a function of distance upstream from Glen Canyon Dam. $A$, May/ June 2014; and $B$, August 2015. Sites along the main stem are connected in series with the blue line. Sites not within the main stem are plotted as a function of the distance where the mouth of that incoming "arm" (river arm, side canyon, or embayment) intersects with the main stem. The site identifiers are indicated for each point.

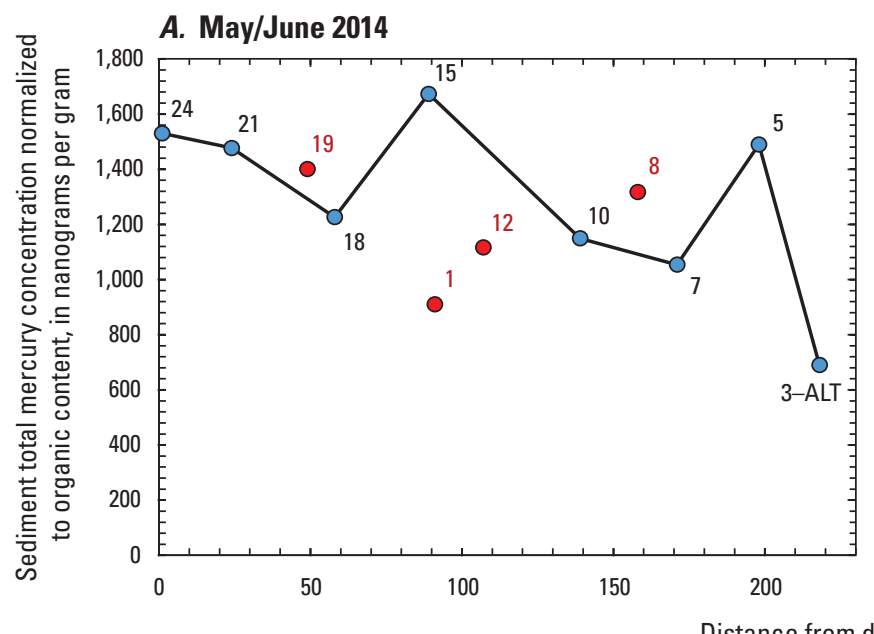

\section{A. May/June 2014}

\section{B. August 2015}

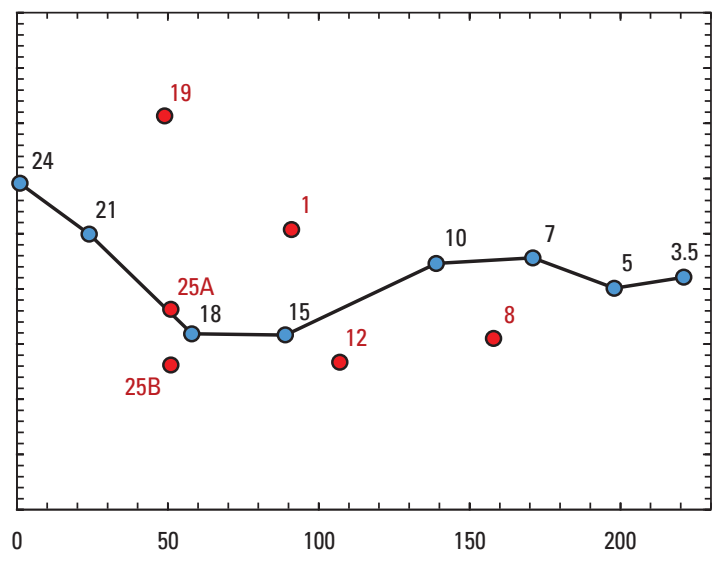

EXPLANATION

Site along the main stem

O Site not within the main stem-Symbols are plotted as a function of the distance where the mouth of that incoming arm (river arm, side canyon, or embayment) intersects with the main stem

Figure 22. Sediment total mercury concentration normalized to organic content as a function of distance upstream from Glen Canyon Dam. A, May/June 2014; and B, August 2015. Sites along the main stem are connected in series with the blue line. Sites not within the main stem are plotted as a function of the distance where the mouth of that incoming "arm" (river arm, side canyon, or embayment) intersects with the main stem. The site identifiers are indicated for each point. 
A. May/June 2014

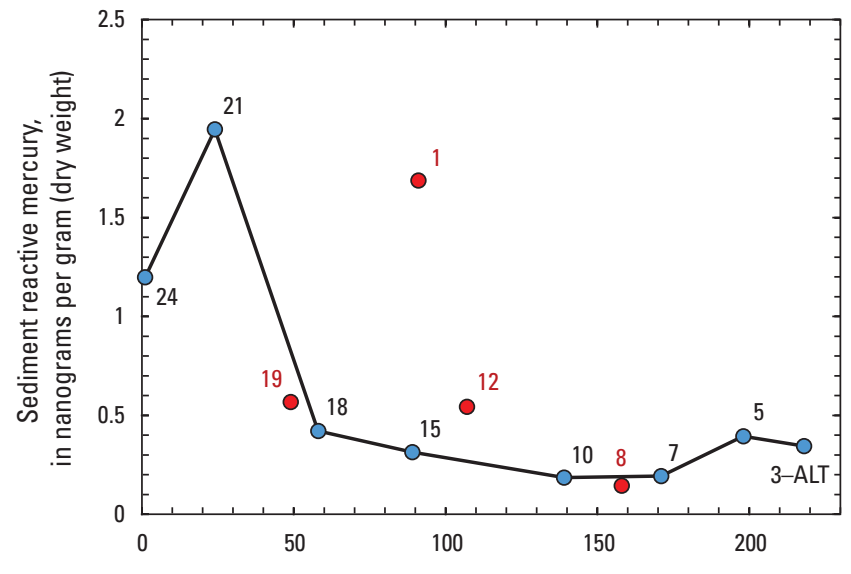

\section{B. August 2015}

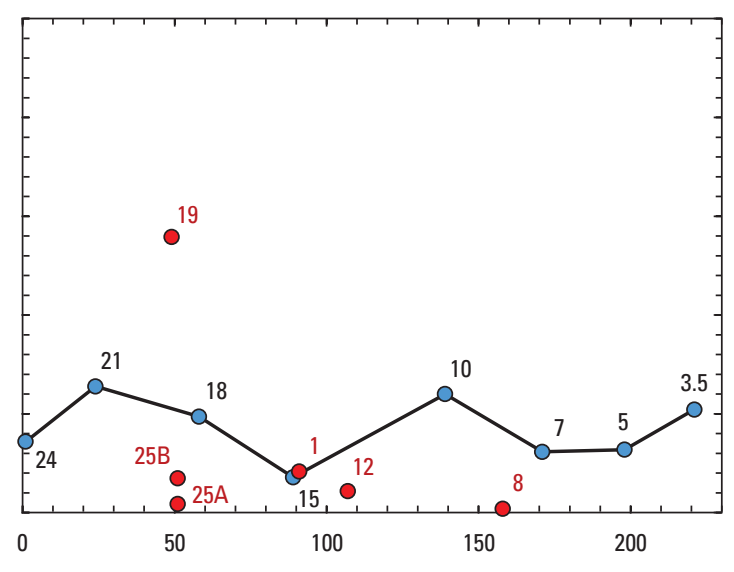

EXPLANATION

Figure 23. Sediment reactive mercury concentration as a function of distance upstream from Glen Canyon Dam. $A$, May/June 2014; and B, August 2015. Sites along the main stem are connected in series with the blue line. Sites not within the main stem are plotted as a function of the distance where the mouth of that incoming "arm" (river arm, side canyon, or embayment) intersects with the main stem. The site identifiers are indicated for each point.

A. May/June 2014

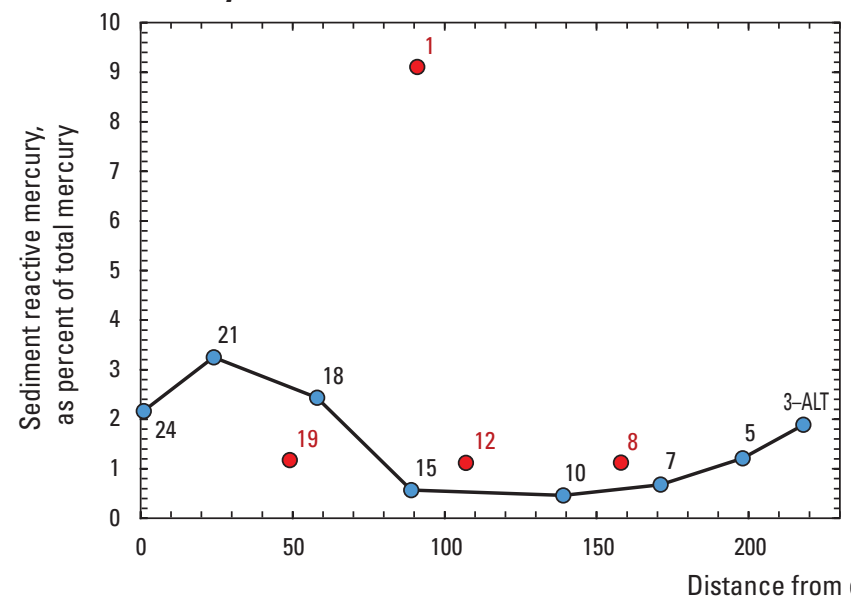

\section{B. August 2015}

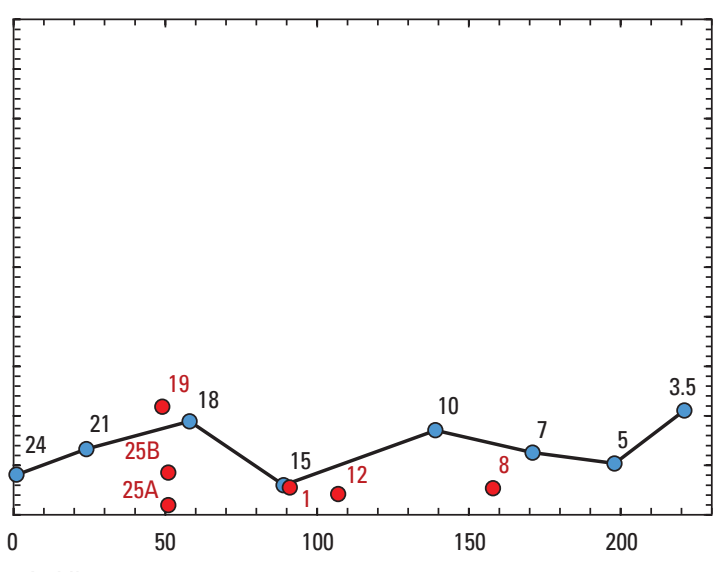

EXPLANATION

S Site along the main stem

- Site not within the main stem-Symbols are plotted as a function of the distance where the mouth of that incoming arm (river arm, side canyon, or embayment) intersects with the main stem

Figure 24. Sediment reactive mercury percentage as a function of distance upstream from Glen Canyon Dam. A, May/ June 2014; and B, August 2015. Sites along the main stem are connected in series with the blue line. Sites not within the main stem are plotted as a function of the distance where the mouth of that incoming "arm" (river arm, side canyon, or embayment) intersects with the main stem. The site identifiers are indicated for each point. 


\section{A. May/June 2014}

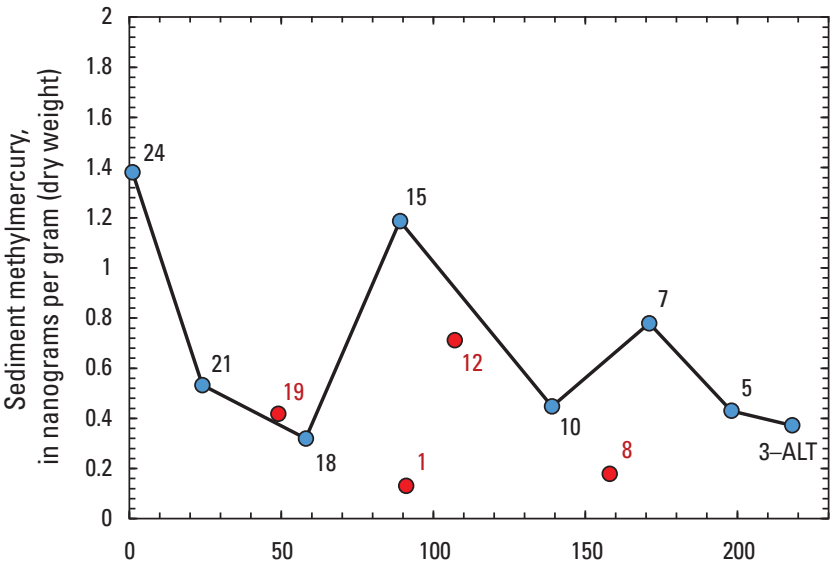

\section{B. August 2015}

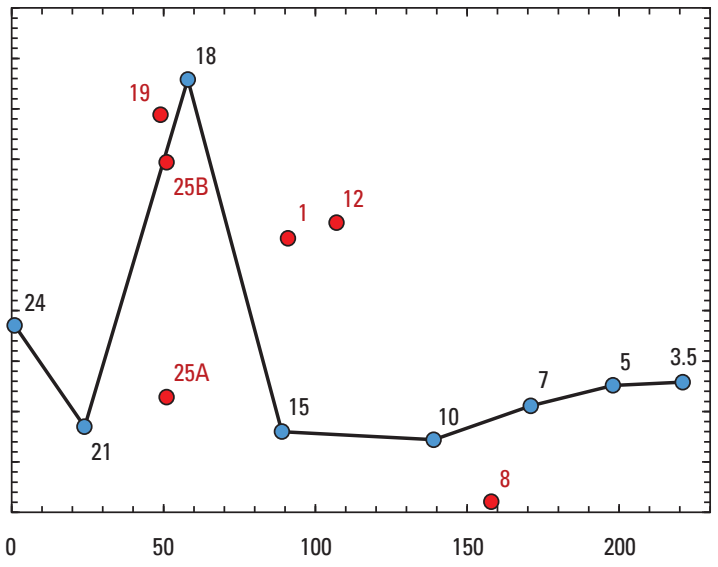

\title{
EXPLANATION
}

\author{
O Site along the main stem \\ O Site not within the main stem-Symbols are plotted as a function \\ of the distance where the mouth of that incoming arm (river arm, \\ side canyon, or embayment) intersects with the main stem
}

Figure 25. Sediment methylmercury as a function of distance upstream from Glen Canyon Dam. A, May/June 2014; and $B$, August 2015. Sites along the main stem are connected in series with the blue line. Sites not within the main stem are plotted as a function of the distance where the mouth of that incoming "arm" (river arm, side canyon, or embayment) intersects with the main stem. The site identifiers are indicated for each point.

\section{A. May/June 2014}

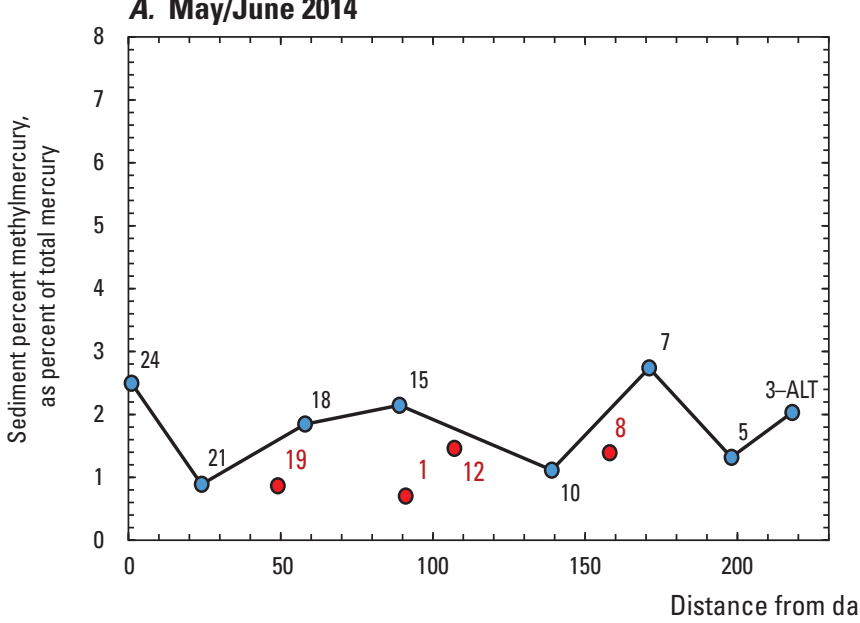

\section{B. August 2015}

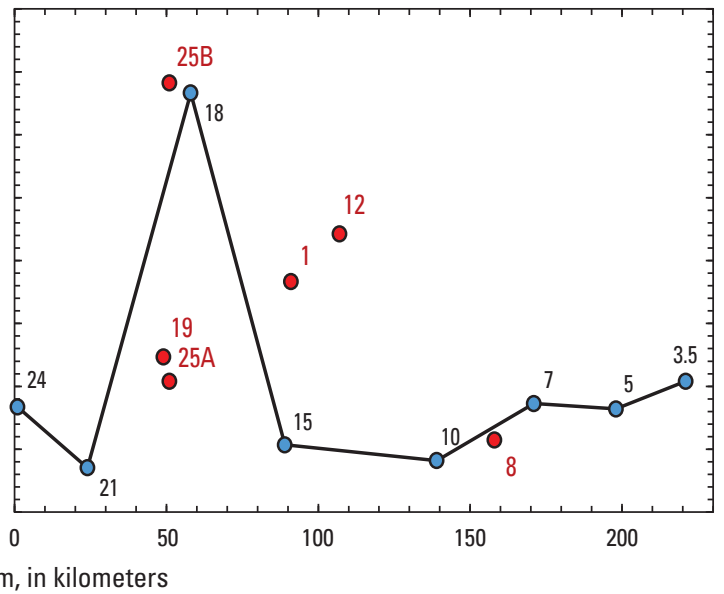

\section{EXPLANATION}

\section{O Site along the main stem}

- Site not within the main stem-Symbols are plotted as a function of the distance where the mouth of that incoming arm (river arm, side canyon, or embayment) intersects with the main stem

Figure 26. Sediment percent methylmercury as a function of distance upstream from Glen Canyon Dam. $A$, May/ June 2014; and $B$, August 2015. Sites along the main stem are connected in series with the blue line. Sites not within the main stem are plotted as a function of the distance where the mouth of that incoming "arm" (river arm, side canyon, or embayment) intersects with the main stem. The site identifiers are indicated for each point. 
The spatial trend in stable isotope derived $\mathrm{Hg}(\mathrm{II})$-methylation rate constant $\left(\mathrm{k}_{\text {meth }}\right)$ approximately doubled along the main stem from 0.005 per day (d) at the upstream end of the reservoir to $0.011 / \mathrm{d}$ at LP-24 nearest the dam (fig. 27) during 2014. The spatial trend changed substantially during 2015, when peak values were measured at the most upstream site (LP-3.5; 0.018/d) and LP-18 (0.026/d). This peak at LP-18 mirrors the peak at the same site seen in the $\mathrm{MeHg}$ concentration (fig. 25) and \%.MeHg (fig. 26). Statistical analysis revealed significantly higher sediment $\mathrm{k}_{\text {meth }}$ values during the late season (2015) compared to the early season (2014), when controlling for spatial differences among sites (appendixes 3 and 4), but no spatial differences when controlling for season. MPP rates (calculated from $\mathrm{k}_{\text {meth }}$ and $\mathrm{RHg}$ data) exhibited a smooth progressive four-fold increase from the upper reservoir (LP-3-ALT; 24 nanograms per square meters per day $\left.\left[\mathrm{ng} / \mathrm{m}^{2} / \mathrm{d}\right]\right)$ to the dam (LP-24; $117 \mathrm{ng} / \mathrm{m}^{2} / \mathrm{d}$ ) during 2014 (early-season synoptic sampling) (fig. 28). During 2015 (late-season synoptic sampling), the MPP rate spatial trend along the main stem much more strongly paralleled that of $\mathrm{k}_{\text {meth }}$ (fig. 27), with peak values at the most upstream site (LP-3.5; $\left.122 \mathrm{ng} / \mathrm{m}^{2} / \mathrm{d}\right)$ and LP-18 (134 ng/m²/d). The highest observed MPP rate was measured in the river arm/side canyon/ embayment site LP-19 (196 ng/m²/d) during 2015. Statistical analysis revealed significantly higher sediment $\mathrm{k}_{\text {meth }}$ values in the lower reservoir, compared to the upper reservoir, and higher values in the main stem, compared to river arm/side canyon/embayment sites, when controlling for temporal differences among sampling season but no seasonal differences when controlling for location (appendixes 3 and 4).

During 2014, the stable isotope derived MeHg degradation rate constant $\left(\mathrm{k}_{\mathrm{deg}}\right)$ was generally greater at the upper end of the reservoir compared to the downstream end, particularly the lower $50 \mathrm{~km}$ nearest the dam (fig. 29), and the highest values were measured at LP-10 $\left(0.35 \mathrm{~d}^{-1}\right)$. A peak at LP-10 also was observed during 2015 , but it was five-fold lower $\left(0.07 \mathrm{~d}^{-1}\right)$ than during 2014. Values of $\mathrm{k}_{\mathrm{deg}}$ were significantly $(p<0.1)$ higher in the upper reservoir, compared to the lower reservoir, when controlling for season (appendix 4).

During 2014, MDP rates (calculated from $\mathrm{k}_{\text {deg }}$ and $\mathrm{MeHg}$ concentration data) along the main stem were notably greater in the upper reservoir (from LP-3-ALT to LP-15) compared to the lower reservoir (LP-18 to LP-24) (fig. 30), although not statistically significant (appendix 4). In contrast, the $\mathrm{k}_{\mathrm{deg}}$ values that were previously elevated during 2014 along the main stem (LP-5 through LP15) were greatly reduced during 2015, when the peak value was instead observed at LP-18 in the lower part of the reservoir. Statistical analysis revealed significantly higher sediment $\mathrm{k}_{\text {meth }}$ values in the upper reservoir, compared to the lower reservoir, and higher values in the main stem, compared to river arm/side canyon/embayment sites, when controlling for temporal differences among sampling season. No statistically significant differences in $\mathrm{k}_{\text {meth }}$ values were measured between years or between main stem and river arm/ side canyon/embayment sites (appendix 3). For calculated MDP rates, there were no significant differences between sampling seasons nor between the upper and lower reservoir (appendix 4), but MDP rates were weakly significantly higher in main stem sites compared to river arm/side canyon/embayment sites (appendix 3).

Net change in ambient $\mathrm{MeHg}$ pool.-An alternative to the use of stable isotopes to assess $\mathrm{MeHg}$ production or degradation is to track the change in ambient $\mathrm{MeHg}$ concentrations over a long enough time frame to assess net $\mathrm{MeHg}$ production or degradation. This was done by tracking the change in the ambient $\mathrm{MeHg}$ concentration (the ambient $\mathrm{Me}^{202} \mathrm{Hg}$ isotope, which is not one of the enriched isotopes used) in the 7-day MDP incubations (metric code is NET.chng.MeHg.7d). There was a clear and statistically significant increase from upstream to downstream in the rate of net $\mathrm{MeHg}$ production based on changes in this ambient $\mathrm{MeHg}$ pool (fig. 31; appendix 4).

Mercury isotopes.-A total of 13 sediment samples collected from Lake Powell during the 2014 synoptic study also were analyzed for $\delta^{202} \mathrm{Hg}$ and $\Delta^{199} \mathrm{Hg}$ and were compared to the isotope data associated with the fish tissue samples (fig. 19). Although the sediment isotopic data collected from the same three sites as the fish tissue fall along the same general line, some of the sediment isotopic data collected from other locations plot distinctly to the left on the $\delta^{202} \mathrm{Hg}$ (x-axis) of the intersection point with the line associated with the fish $\Delta^{199} \mathrm{Hg}$ and $\delta^{202} \mathrm{Hg}$ results and the expected composition of the $\mathrm{MeHg}$ source (Bergquist and Blum, 2007).

$16 \mathrm{~S}$ rRNA gene templates.-Quantitative polymerase chain reaction was used to determine the abundances of 16S rRNA gene templates as a proxy for microbial biomass (archaea, Bacteria, and chloroplast encoding eukarya) in sediment samples collected at intensive sampling sites during the early-season (May/June 2014) and late-season (August 2015) synoptic sampling trips. The abundance of $16 \mathrm{~S}$ rRNA genes in sediments collected from the upper reservoir in spring 2014 was greater, on average, than those collected from the lower reservoir (appendix 4). This pattern is similar to that observed with the abundance of $16 \mathrm{~S}$ rRNA genes in water samples collected from the upper versus lower reservoir during the earlyseason synoptic sampling (fig. 20). In contrast, the abundance of $16 \mathrm{~S}$ rRNA genes in sediment collected from the lower reservoir during the late-season synoptic sampling was greater, on average, than those collected from the upper reservoir. This pattern is similar to what was observed with the abundance of $16 \mathrm{~S}$ rRNA genes in water samples collected from the upper versus lower reservoir during the late-season synoptic sampling in 2015. On average, the abundance of templates in all sediment samples collected during 2015 was greater than in those collected in 2014 (appendix 4). This pattern is similar to what was observed with the abundance of $16 \mathrm{~S}$ rRNA genes in water samples collected from the upper versus lower reservoir during the early-season (2014) and late-season (2015) synoptic sampling trips. 


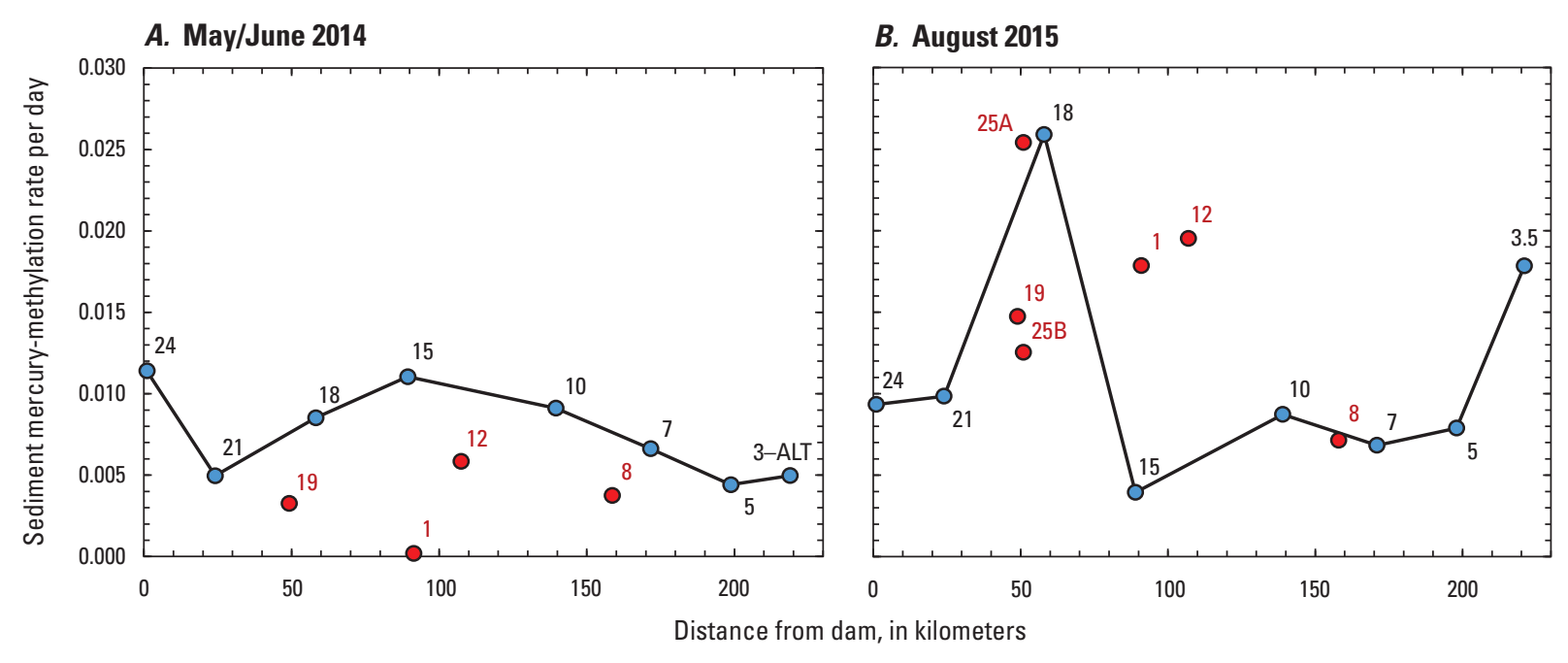

\title{
EXPLANATION
}

\begin{abstract}
Site along the main stem
O Site not within the main stem-Symbols are plotted as a function of the distance where the mouth of that incoming arm (river arm, side canyon, or embayment) intersects with the main stem
\end{abstract}

Figure 27. Sediment mercury-methylation rate constant as a function of distance upstream from Glen Canyon Dam. A, May/June 2014; and B, August 2015. Sites along the main stem are connected in series with the blue line. Sites not within the main stem are plotted as a function of the distance where the mouth of that incoming "arm" (river arm, side canyon, or embayment) intersects with the main stem. The site identifiers are indicated for each point.

A. May/June 2014

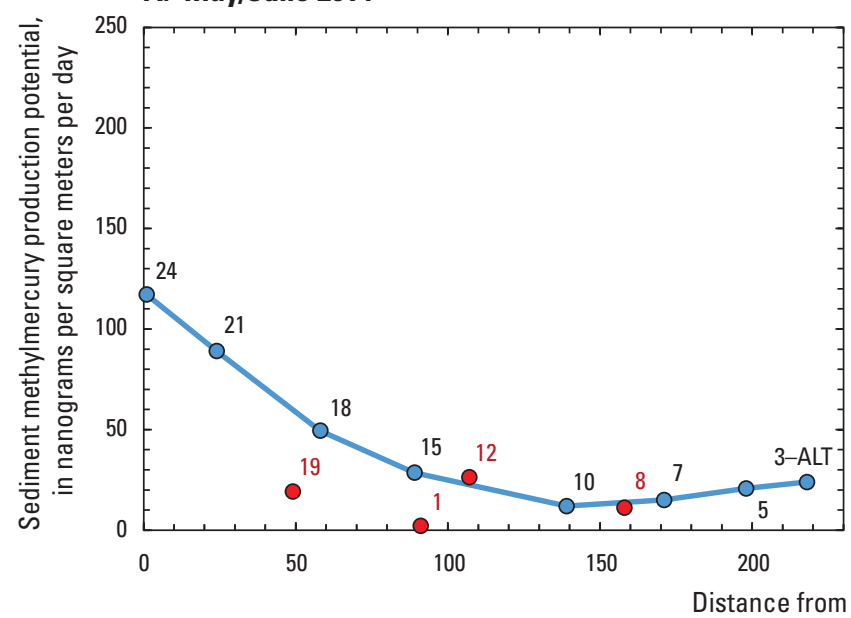

\section{B. August 2015}

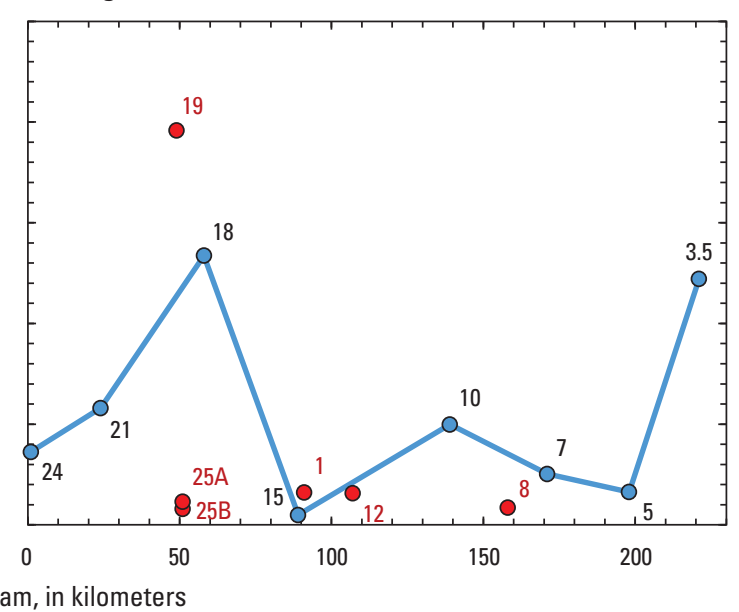

\section{EXPLANATION}

\section{S Site along the main stem}

- Site not within the main stem-Symbols are plotted as a function of the distance where the mouth of that incoming arm (river arm, side canyon, or embayment) intersects with the main stem

Figure 28. Sediment methylmercury production potential rate as a function of distance upstream from Glen Canyon Dam. A, May/June 2014; and B, August 2015. Sites along the main stem are connected in series with the blue line. Sites not within the main stem are plotted as a function of the distance where the mouth of that incoming "arm" (river arm, side canyon, or embayment) intersects with the main stem. The site identifiers are indicated for each point. 


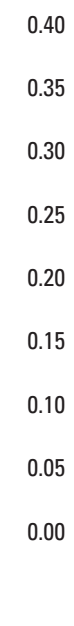

A. May/June 2014

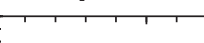

\section{4}
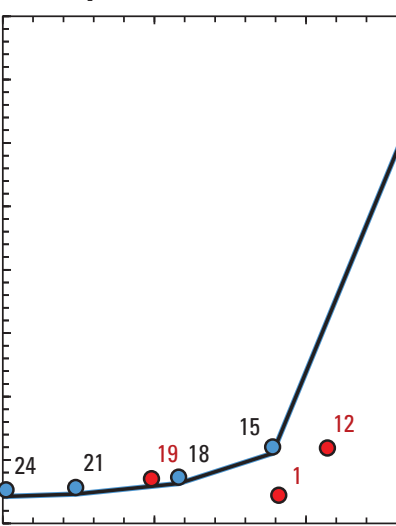

50

50

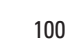

100

150

\section{B. August 2015}

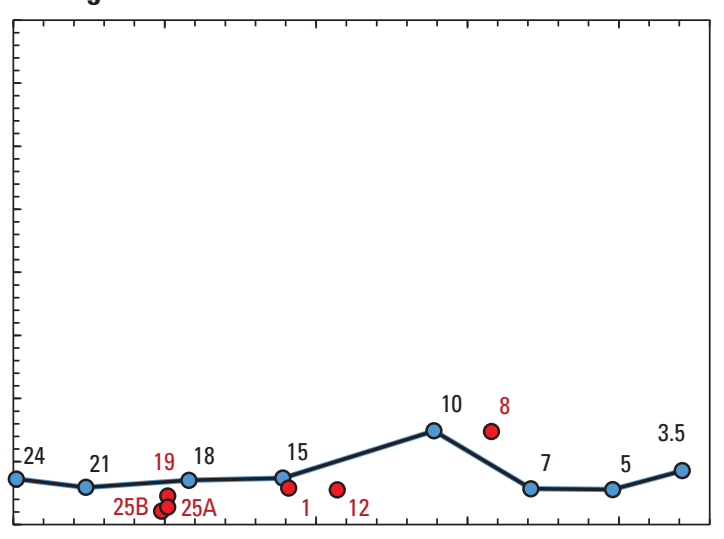

0

50

100

200

Distance from dam, in kilometers

\section{EXPLANATION}

\section{O Site along the main stem}

O Site not within the main stem-Symbols are plotted as a function of the distance where the mouth of that incoming arm (river arm, side canyon, or embayment) intersects with the main stem

Figure 29. Sediment methylmercury degradation rate constant as a function of distance upstream from Glen Canyon Dam. A, May/June 2014; and B, August 2015. Sites along the main stem are connected in series with the blue line. Sites not within the main stem are plotted as a function of the distance where the mouth of that incoming "arm" (river arm, side canyon, or embayment) intersects with the main stem. The site identifiers are indicated for each point.

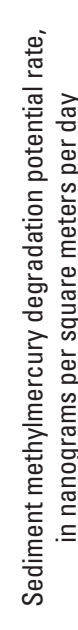

\section{A. May/June 2014}

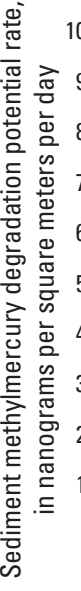

\section{A. May/June 2014}

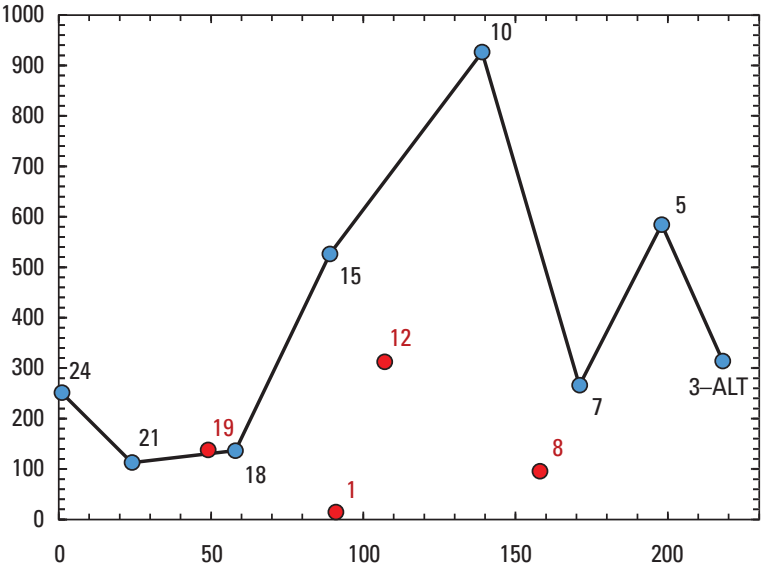

\section{B. August 2015}

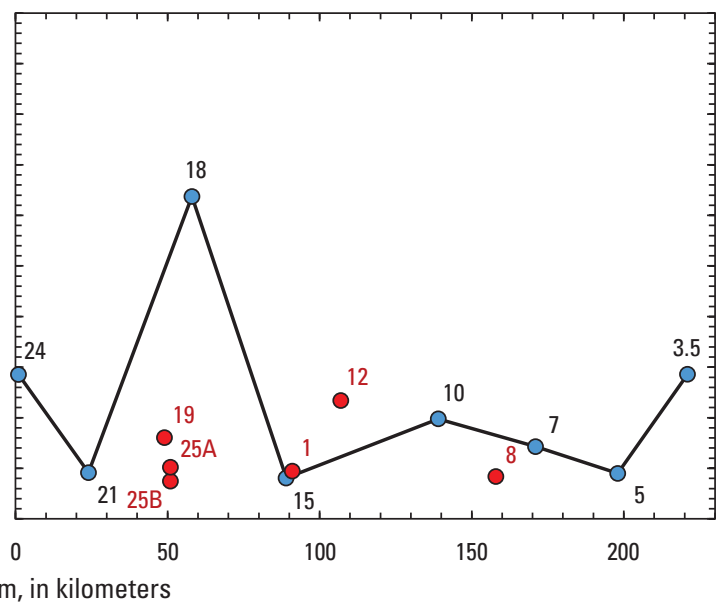

EXPLANATION

Site along the main stem

O Site not within the main stem-Symbols are plotted as a function of the distance where the mouth of that incoming arm (river arm, side canyon, or embayment) intersects with the main stem

Figure 30. Sediment methylmercury degradation potential rate as a function of distance upstream from Glen Canyon Dam. A, May/June 2014; and B, August 2015. Sites along the main stem are connected in series with the blue line. Sites not within the main stem are plotted as a function of the distance where the mouth of that incoming "arm" (river arm, side canyon, or embayment) intersects with the main stem. The site identifiers are indicated for each point. 
A. May/June 2014

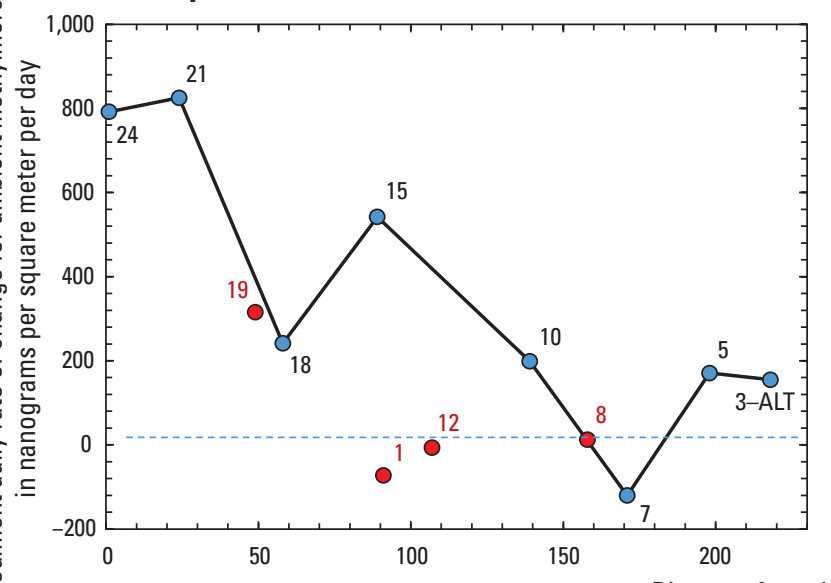

B. August 2015

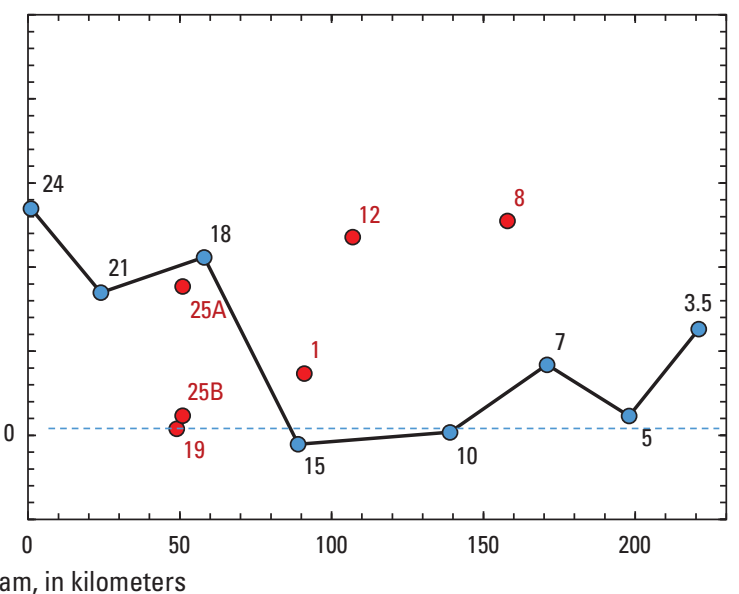

EXPLANATION

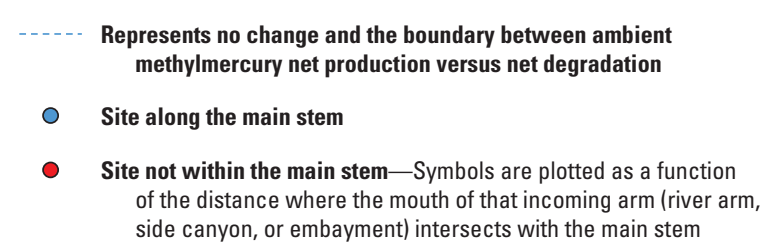

Figure 31. Sediment daily rate of change for the ambient methylmercury pool (7-day incubations) as a function of distance upstream from Glen Canyon Dam. $A$, May/June 2014; and $B$, August 2015. Sites along the main stem are connected in series with the blue line. Sites not within the main stem are plotted as a function of the distance where the mouth of that incoming "arm" (river arm, side canyon, or embayment) intersects with the main stem. The site identifiers are indicated for each point.

\subsection{Discussion of Biogeochemical and Physical Processes}

The main objective of this study was to determine the underlying processes that resulted in the spatial trend of $\mathrm{Hg}$ concentrations in striped bass being higher in the lower $(\sim 100 \mathrm{~km})$ part of Lake Powell compared to the upper part, resulting in a fish consumption advisory being issued for the lower one-half of the reservoir (Utah Department of Environmental Quality, 2012). A conceptual model (fig. 2) that outlines a plausible framework for elevated $\mathrm{Hg}$ concentration in striped bass tissue samples from the lower part of the reservoir was developed. Key features of the conceptual model include inflowing water at the upstream end of the system carrying a large suspended inorganic sediment load that drives light limitation of primary production. The middle part of Lake Powell acts as a transition zone where the reservoir widens and the water velocities decrease. In this zone, the reservoir transitions from largely lotic (riverine) to largely lentic (lake like) and the denser inorganic particulates begin to settle out, leading to more light penetration and enhanced primary production. This enhanced primary production may well exist in the upper one-third of the reservoir initially; however, as the water moves further downstream, nutrient limitation, as opposed to light limitation, becomes the dominant factor controlling primary production in the lower two-thirds of this reservoir system. Particulates sinking through the water column from the photic zone and epilimnion transition from denser and larger inorganic particulates kept in suspension in the higher velocity riverine upper system to largely phytoplankton and slow settling silt- and clay-sized particles in the lower part of the system. This shift in particle type drives an increase in labile organic matter (in the form of phytoplankton) in the transition from the upper to the lower reservoir, and this subsequently drives higher rates of heterotrophic microbial activity that is dependent on labile organic matter. In general, the higher rate of overall microbial activity can drive higher rates of microbial $\mathrm{Hg}(\mathrm{II})$-methylation. This higher propensity for $\mathrm{Hg}$ (II)-methylation in the lower part of the system, in the water column, bottom sediment, or both, is the ultimate driver of enhanced MeHg uptake into the base of the food web and potential bioaccumulation up the food chain where it is reflected in higher Hg levels in the striped bass in the lower $\sim 100 \mathrm{~km}$ of the reservoir. Two corollaries that stem from this overall conceptual model that focuses on upper versus lower reservoir spatial trends (fig. 2) extend these concepts to the spatial differences between the main stem and arm sites (side canyons and secondary river arms) (hypothesis 2) and 
temporal differences based on high-flow versus low-flow hydrologic conditions (hypothesis 3 ).

The fish tissue samples collected during November 2014 (this study) supported the spatial trends in fish tissue $\mathrm{Hg}$ concentrations detected in the original data collected by State agencies that led to the fish consumption advisory in the lower part of the reservoir. Striped bass collected from Wahweap Bay contained higher $\mathrm{Hg}$ concentrations than bass from Good Hope Bay (figs. 3, 18). In addition, the 2014 fish tissue data also indicated that fish collected in the San Juan Arm of Lake Powell contained higher Hg concentrations than fish tissue samples collected from the lower reservoir. This finding indicates that the initial longitudinal conceptual model, focused solely on upper to lower reservoir transition along the main stem, needed to be expanded to consider a second spatial axis; one that includes potential differences in $\mathrm{Hg}$ cycling and bioaccumulation between the Lake Powell main stem and sites off the main stem (river arms, side canyons, and embayments). The three hypotheses associated with this expanded conceptual model were statistically tested with chemical and biological constituents collected during the study (appendixes 2-6). Graphical approaches were used to reinforce statistical trends and to investigate trends that were not captured by the statistical models. Conclusions from the study are derived from a combination of statistical and graphical evidence.

Hypothesis 1 (associated statistical tests include LSM models A, B.1, and C) focuses on the primary spatial axis and considers if significant differences in $\mathrm{Hg}$ and non- $\mathrm{Hg}$ parameters exist between the upper and lower reservoir. Hypothesis 2 (associated statistical tests include LSM models A, B.1/B.2, and $\mathrm{C}$ ) is associated with the other spatial axis, questioning if river arms/side canyons/embayments (that is, San Juan and Escalante Arms) differ from the Lake Powell main stem (defined by the historical flow path of the Colorado River) with respect to $\mathrm{Hg}$ cycling and bioaccumulation. Hypothesis 3 (associated statistical tests include LSM Models A, B.1/B.2, and $\mathrm{C}$ ) is focused on the temporal scale and questions if there is a seasonal component to the conceptual model. Specifically, the assessment of results focused on determining if there are temporal differences in the components that underlie this framework (for example, primary production, $\mathrm{MeHg}$ production, and so on) between the early-season period (May/June), when stratification is initially setting up, and the late-season period (August), when stratification is typically at its strongest.

The three hypotheses are defined below:

Hypothesis 1.-There are spatial differences, between the upper and lower reservoir, in key $\mathrm{Hg}$ and non-Hg metrics that support the conceptual model and lead to higher Hg concentrations in striped bass in the lower reservoir (0 to $100 \mathrm{~km}$ from Glen Canyon Dam).

Hypothesis 2.-There are spatial differences, between the reservoir main stem sites and river arm/side canyon/ embayment sites, in key $\mathrm{Hg}$ and non-Hg metrics that support the conceptual model and lead to higher Hg concentrations in striped bass in arm sites.
Hypothesis 3.-There are temporal differences in $\mathrm{Hg}$ and non-Hg metrics between the early-season (May/June 2014, before strong stratification) period and the late-season (August 2015, during stratified conditions) period that lead to higher $\mathrm{Hg}$ concentrations at the base of the food web (phytoplankton and zooplankton) during the late-season period.

Statistical results and observations supporting or refuting each of the three hypotheses are discussed below in the context of the various sampling media of water, plankton, and sediment.

\subsection{Hypothesis 1 (Upper Versus Lower Reservoir)}

Water.-Of the 45 water-column parameters, 20 exhibited a statistically significant $(p<0.05)$ difference between the upper $(\geq 100 \mathrm{~km}$ from Glen Canyon Dam) and lower $(<100 \mathrm{~km}$ from Glen Canyon Dam) regions along the main stem of Lake Powell (appendix 2). Details on selected water-column parameters are presented below.

LSM-modeled TURB was significantly higher in the upper reservoir (5.44 $\pm 1.48 \mathrm{NTUs)}$, compared to the lower reservoir (0.83 \pm 0.25 NTUs) (appendix 2). Graphically, an elevated ( $>10$ NTUs) TURB plume extending to $110 \mathrm{~km}$ above Glen Canyon Dam was observed during the earlyseason synoptic sampling (fig. 14) and likely reflects the corresponding sediment load that accompanies the spring freshet that also transports nutrients into the epilimnion (Stanford and Ward, 1991). An elevated (>10 NTUs) TURB plume also is observed in the upper part of the reservoir $(>170 \mathrm{~km}$ above the dam) during the late-season synoptic sampling; however, it is much smaller than the TURB plume observed during the early-season synoptic sampling (fig. 14). This trend of higher TURB in the upper reservoir is consistent with hypothesis 1 and the conceptual model (fig. 2), where river inflow contributes inorganic particles and these larger inorganic particles settle out of the water column in the lower reservoir as water velocities decrease.

LSM-modeled percent POC increased from $6.45 \pm 0.69$ percent dry weight in the upper reservoir to $12.41 \pm 1.46$ percent dry weight in the lower reservoir. The low percent POC in the upper reservoir is consistent with hypothesis 1 and reflects a shift towards increased phytoplankton relative to inorganic particles moving from upstream to downstream. This trend also is consistent with earlier observations on the distribution of suspended particles in the reservoir (Stanford and Ward, 1991).

LSM-modeled chlorophyll $a$ (chl.a [lab]) concentrations significantly $(p<0.05)$ decreased from the upper to lower reservoir while controlling for season (appendix 2). Although this trend seems inconsistent with the conceptual model, it is most likely reflective of nutrient limitation in the lower reservoir limiting phytoplankton growth. LSM-modeled phosphate and ammonium concentrations also significantly decreased from the upper to lower reservoir (appendix 2), supporting the indication that nutrient limitation of primary 
production supplanted light limitation in the downstream direction. Although the statistical analysis was limited to the physical water samples collected, a more detailed picture of chl.a distribution was provided by the in-situ chl.a measurements generated by the water-quality sonde (fig. 16). In-situ chl.a was low $(<2 \mu \mathrm{g} / \mathrm{L})$ in the upper reservoir during the early-season synoptic sampling (fig. 16), likely reflecting light limitation from the elevated TURB. During the early season, a lens of increased chl.a concentration was observed in the lower one-half of Lake Powell (fig. 16), likely reflecting the lower TURB (fig. 14) and increased light penetration. During the late-season synoptic sampling, the highest chl.a concentrations measured via the water-quality sonde were observed in $<10 \mathrm{~m}$ of water depth in the upper one-half of the reservoir, reflecting the increased amount of light penetration from the lower TURB plumes (relative to the early season). The low $(<2 \mu \mathrm{g} / \mathrm{L})$ chl.a concentrations in the near-surface depths in the lower one-half of the reservoir during the late-season synoptic sampling are consistent with low nutrient conditions after early summer phytoplankton production in the epilimnion, which was driven by nutrient loading during the spring freshet (Stanford and Ward, 1991).

LSM-modeled gravimetric particulate methylmercury (p.MeHg.mass), methylmercury partition coefficient $\left(\mathrm{K}_{\mathrm{d}}[\mathrm{MeHg}]\right)$, total mercury partition coefficient $\left(\mathrm{K}_{\mathrm{d}}[\mathrm{THg}]\right)$, and the percent of particulate methylmercury (\%p.MeHg) all exhibited a statistically significant $(p<0.05)$ increase in the lower reservoir relative to the upper reservoir (appendix 2). These trends with respect to particulate methyl and total $\mathrm{Hg}$ are consistent with hypothesis 1 and the conceptual model, potentially indicating enhanced water-column $\mathrm{MeHg}$ production associated with particulates in the lower part of the reservoir. Alternatively, these trends may simply reflect the observed increase in percent POC in the downstream direction (appendix 2) as heavier inorganic particles are deposited in the upper reservoir, with the remaining particulate organic matter being enriched in $\mathrm{MeHg}$.

The downstream trend in THg metrics was opposite that for MeHg in that LSM-modeled concentrations for f.THg, volumetric particulate total mercury, and unfiltered total mercury were all significantly lower $(p<0.05)$ in the lower reservoir (appendix 2). Although these trends for THg would seem to run counter to hypothesis 1 , it is more likely the concentration of $\mathrm{MeHg}$, and not THg, that drives the downstream increase in $\mathrm{Hg}$ at the base of the food web and, ultimately, in striped bass.

Plankton.- Higher bulk plankton THg and $\mathrm{MeHg}$ concentrations were generally observed in the lower reservoir, compared to the upper reservoir (fig. 18). However, differences between the upper and lower sections of Lake Powell were only statistically significant for volumetric and gravimetric THg (appendix 5). LSM-modeled gravimetric bulk plankton biomass concentrations also were significantly higher in the lower reservoir, compared to the upper reservoir (appendix 5). This trend was driven primarily by the significant decrease in the TSS concentration in the lower reservoir, relative to the upper reservoir (appendix 2). These increases in gravimetric bulk plankton $\mathrm{Hg}$ concentrations and biomass in the lower reservoir support hypothesis 1 and are consistent with the conceptual model. Furthermore, this relation indicates a more bioavailable pool of inorganic $\mathrm{Hg}$ and higher uptake of $\mathrm{MeHg}$ at the lower trophic levels.

Sediment.-To the extent that increased MeHg production in the lower part of the reservoir drives the increased $\mathrm{Hg}$ observed in striped bass in that part of Lake Powell, the compartment where increased $\mathrm{MeHg}$ production might be most apparent is expected in surface sediment. To this point, evidence of higher $\mathrm{MeHg}$ production was observed, among a number of metrics, in the lower part of the reservoir compared to the upper reservoir. Specifically, there was a clear and statistically significant increase from upstream to downstream in the rate of net $\mathrm{MeHg}$ production based on changes in the ambient MeHg pool during 7-day bottle incubations (metric code is NET.chng.MeHg.7d, fig. 31, appendix 4). However, there also was a significant interaction effect for the YEAR $\times$ TYPE. 2 term in model B.2, which indicated the significant difference between the upper and lower reservoir was limited to May/ June 2014 and not significant during August 2015 (fig. 32A, appendix 4). Similarly, MPP rates (on a dry weight basis) also indicated a weakly significant difference between the upper and lower reservoir overall ( $p=0.086$, appendix 4$)$, driven primarily during May/June 2014 (fig. 28A) but not during August 2015 (fig. 28B). Conversely, MPP expressed on an areal basis exhibited no significant differences between the upper and lower reservoir sites (appendix 4). Because MPP rates were calculated as a function of the isotope incubation derived rate constants $\left(\mathrm{k}_{\text {meth }}\right)$ and the pool of ambient $\mathrm{RHg}(\mathrm{II})$ (assumed to be generally available for $\mathrm{Hg}[\mathrm{II}]$-methylation), during 2014 the spatial trend in MPP rates (dry weight basis) along the main stem was largely driven by the spatial trend in RHg (fig. 23A), as opposed to the more muted trend of $\mathrm{k}_{\text {meth }}$ (fig. 27A) during 2014. Conversely, during 2015, the variable upstream to downstream trend in calculated MPP rates was more strongly driven by spatial variability in $\mathrm{k}_{\text {meth }}$ (fig. $27 B$ ), compared to the more muted variability in RHg concentration (fig. 23B). In light of these observations, a shift might be inferred in the mechanisms that control MeHg production during different periods of the year, from $\mathrm{Hg}$ (II) availability for methylation during the late spring/early summer period to largely microbial activity during the late summer period.

An alternate metric that is sometimes used to infer $\mathrm{Hg}(\mathrm{II})$-methylation efficiency among sites is the concentration of $\mathrm{MeHg}$ relative to $\mathrm{THg}$, as a percentage $(\% \mathrm{MeHg})$. Although this is not a rate measurement, and is based solely on concentration data, the assumption is that sites with a higher $\% \mathrm{MeHg}$ are more effective at producing $\mathrm{MeHg}$ (that is, they have a higher MeHg production capability). There are a number of potential critiques in interpreting $\% \mathrm{MeHg}$ data in this manner, including (a) concentrations are not rates and (b) the competing processes of $\mathrm{MeHg}$ production versus $\mathrm{MeHg}$ degradation are always at play and determine the $\mathrm{MeHg}$ concentration 

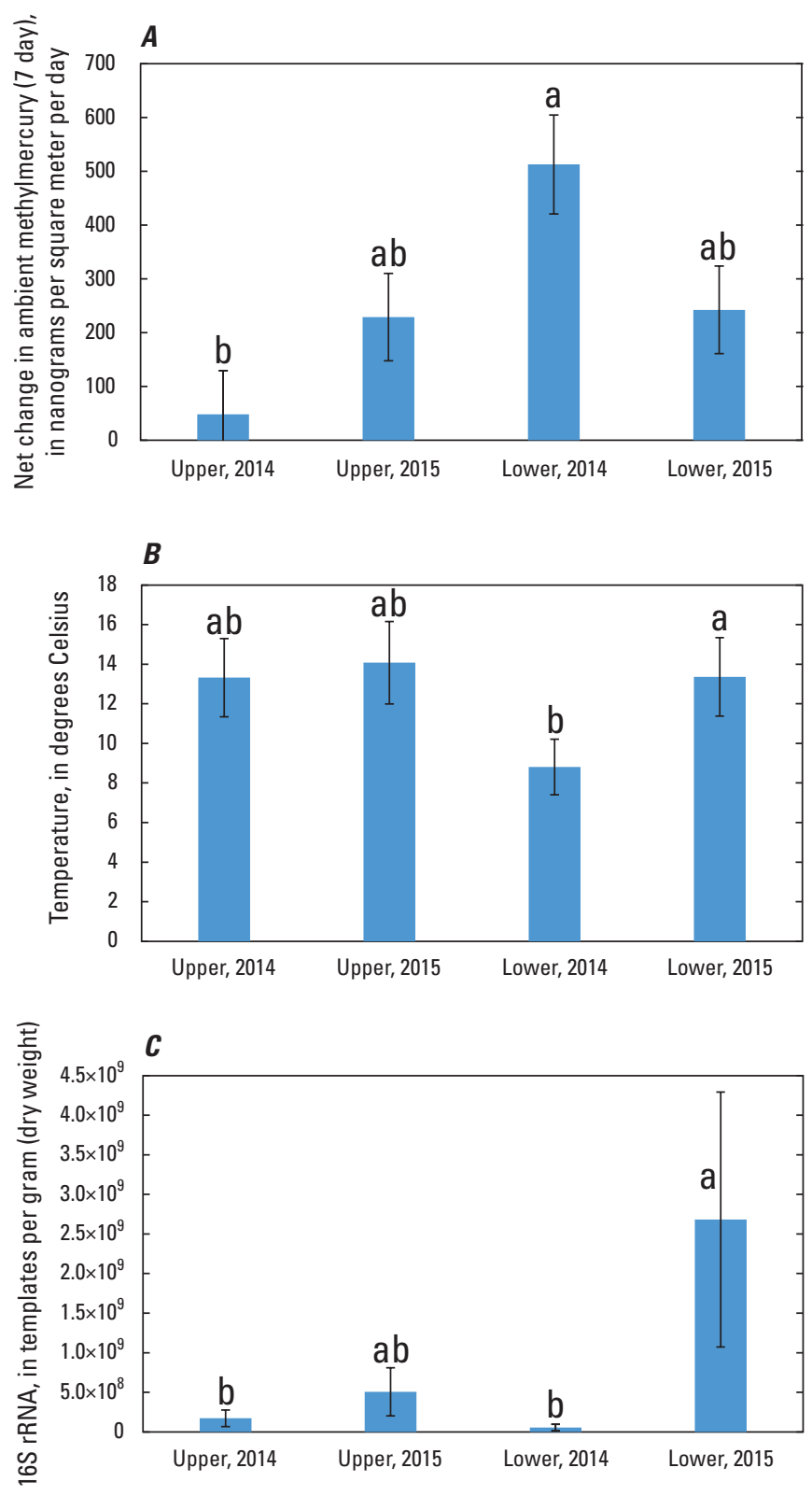

Figure 32. The model B.2 least square mean results associated with the interaction term (YEAR $\times$ TYPE.2) for sediment. $A$, Rate of change of the ambient methylmercury pool (7-day incubation); $B$, temperature; and $C$, ribosomal ribonucleic acid, small subunit 16 (16S rRNA). The four interaction categories include upper and lower reservoir sites for 2014 and 2015 (upper, 2014; upper, 2015; lower, 2014; lower, 2015). Tukey's Honestly Significant Difference (Tukey, 1949) results are indicated by lowercase letters, and least square mean values sharing the same letter indicate no significant difference. (and $\% \mathrm{MeHg}$ ) at any given location or time. Thus, inferring a dynamic process such as $\mathrm{MeHg}$ production based on concentration data alone is problematic but is not without precedent (Gilmour and others, 1998; Krabbenhoft and others, 1999; Sunderland and others, 2006). As assessed by the sediment $\% \mathrm{MeHg}$ metric, there was no statistically significant difference between the upper and lower parts of the reservoir (fig. 26, appendix 4). It should be noted that there was a significant positive correlation between values of $\mathrm{k}_{\text {meth }}$ (fig. 27) and $\% \mathrm{MeHg}$ (fig. 26) (correlation coefficient $r=0.63, n=27$ ), as well as between $\mathrm{k}_{\text {meth }}$ and $\mathrm{MeHg}$ concentration (fig. 25) $(r=0.61, n=27)$, indicating that the rate constants derived from the short-term incubations done with the enriched ${ }^{200} \mathrm{Hg}$ (II) isotope were reflective of the standing pool of $\mathrm{MeHg}$ for any given sediment sample. Although, none of these metrics $\left(\mathrm{k}_{\text {meth}}\right.$, $\% \mathrm{MeHg}$, or $[\mathrm{MeHg}])$ indicated significant differences between the upper and lower reservoir, as assessed by model B.2

(appendix 4). So with respect to sediment results overall, some of the metrics commonly used to assess $\mathrm{MeHg}$ production were consistent with hypothesis 1 (specifically, changes in ambient $\mathrm{MeHg}$ concentration during 7-day bottle incubations and calculated MPP rates during May/June 2014), but others were not (including $\mathrm{k}_{\text {meth }}$ alone, $\% \mathrm{MeHg}$, and $\mathrm{MeHg}$ concentration). The ability to clearly discriminate significant temporal and spatial differences with the sediment data was notably limited by the number of observations in this dataset $(n=27)$.

As noted above, $\mathrm{MeHg}$ degradation can also play a major role in affecting the standing pool of $\mathrm{MeHg}$ in surface sediment. Although there were no statistically significant differences in $\mathrm{Me}^{201} \mathrm{Hg}$ isotope amendment derived rate constants for degradation $\left(\mathrm{k}_{\mathrm{deg}}\right)$, nor for calculated potential rates of MDP overall (appendix 4), a visual inspection of the $\mathrm{k}_{\mathrm{deg}}$ and MDP data (figs. 29 and 30) does indicate that these parameters were elevated in the upper reservoir compared to the lower reservoir for main stem sites during May/June 2014 (but not during August 2015). This general spatial trend is the inverse of what was seen for $\mathrm{k}_{\text {meth }}$ and MPP rates for the same sampling period. Thus, during May/June 2014, the high MPP rates in the lower reservoir (fig. 28A), coupled with the high MDP rates in the upper reservoir (fig. 30A), produce a compounded effect that likely led to the strong spatial trend along the main stem during the same period, as assessed by changes in the ambient $\mathrm{MeHg}$ pool during 7-day incubations (fig. 31). The fact that none of these metrics were as pronounced spatially during August 2015 indicates a seasonal shift in benthic microbial Hg-transformation processes and patterns and the factors that control them. 


\subsection{Hypothesis 2 (Reservoir Main Stem Versus River Arms/Side Canyons/Embayments)}

Water.-Of the 45 water-column parameters, 11 exhibited a statistically significant $(p<0.05)$ difference between the main stem and river arm/side canyon/embayment sites of Lake Powell (appendix 2). Detailed discussions regarding a few of these statistically significant $\mathrm{Hg}$ and non-Hg water-column parameters, and how they support or refute hypothesis 2 , are presented in this section.

The LSM-modeled gravimetric particulate methylmercury (p.MeHg.mass), gravimetric particulate total Hg (p.THg. mass), and \%p.MeHg were all significantly $(p<0.05)$ higher in the river arm/side canyon/embayment sites than in the main stem reservoir channel (appendix 2). In addition to these significant differences, there were a number of non-Hg watercolumn parameters that were not statistically significant but trended in a manner that indicates the same factors that drive the spatial trends between the upper and lower reservoir might also drive the differences in the above $\mathrm{Hg}$ metrics between the arm sites and the main stem sites. Specifically, these nonsignificant trends included lower turbidity, higher chlorophyll $a$, and higher percent POC in the arm sites compared to the main stem (appendix 2). The spatial trends for these parameters were consistent with the conceptual model and hypothesis 2 and indicate a pelagic pathway for enhanced $\mathrm{Hg}$ bioaccumulation in striped bass collected from these areas. This indication is further supported by the 2014 striped bass tissue THg concentrations being higher in the San Juan Arm than in Wahweap Bay (lower reservoir, main stem) and Good Hope Bay (upper reservoir, main stem) (fig. 19B).

LSM-modeled ammonia $\left(\mathrm{NH}_{4}{ }^{+}\left[\right.\right.$Thermo Scientific ${ }^{\mathrm{TM}}$ Aquakem ${ }^{\mathrm{TM}}$ analyzer]) concentrations also were statistically $(p<0.05)$ higher in the river arm/side canyon/embayment sites, compared to the main stem reservoir channel (appendix 2). Elevated $\mathrm{NH}_{4}^{+}$may reflect decomposition ( $\mathrm{N}$ remineralization) of phytoplankton in the water column. It is unclear why this process is more dominant in the river arm/side canyon/ embayment sites; however, it may be related to more stagnant hydrologic conditions, particularly in the side canyons fed by ephemeral streams and the Escalante Arm during low-flow conditions.

LSM-modeled nitrate $\left(\mathrm{NO}_{3}^{-}\right)$and nitrite $\left(\mathrm{NO}_{2}^{-}\right)$concentrations were significantly $(p<0.05)$ lower in the arms and side canyons relative to the main stem reservoir channel (appendix 2). This trend may reflect the dominance of the Colorado River as the major input of $\mathrm{NO}_{3}^{-}$and $\mathrm{NO}_{2}^{-}$to Lake Powell or enhanced nitrification (conversion of $\mathrm{NH}_{4}^{+}$to $\mathrm{NO}_{2}^{-}$and $\mathrm{NO}_{3}^{-}$) in the main stem, relative to the river arm/side canyon/embayment sites.

Elevated concentrations of gravimetric particulate methylmercury (p.MeHg.mass) and \%p.MeHg were observed in the river arm/side canyon/embayment sites. Decomposition of phytoplankton in the river arm/side canyon/embayment sites is supported by the predominance of low DO concentrations in these areas relative to the main stem. Although not statistically significant, DO, expressed as percent saturation, was below 10 percent in many of the river arm/side canyon/ embayment sites during the 2015 synoptic sampling trip and in side canyon site LP-25 during the 2014 synoptic sampling trip (fig. 12). DO is generally much higher ( $>40$ percent saturation) in the main stem during 2014 and 2015. These hypoxic watercolumn conditions may themselves help drive $\mathrm{MeHg}$ production within the water columns, likely associated with reduced microzones on slowly sinking organic detritus and plankton (Gascón Díez and others, 2016) under quiescent conditions.

Plankton.-All the plankton Hg parameters were significantly higher in the river arm/side canyon/embayment sites relative to the main stem sites (appendix 5), with strong $(p<0.05)$ or weak $(p<0.10)$ statistical significance. LSM-modeled volumetric and gravimetric bulk plankton biomass concentrations were not significantly different between the main stem and arm sites, while controlling for season and TYPE.2 spatial differences (appendix 5).

LSM-modeled bulk plankton gravimetric and volumetric MeHg and THg concentrations (bulk.MeHg.mass, bulk.THg. mass, bulk.MeHg.vol, and bulk.THg.vol) in the river arm/ side canyon/embayment sites were significantly higher than in the main stem, while controlling for season and TYPE.2 spatial differences (appendix 5). These data support hypothesis 2 and indicate a more bioavailable pool of inorganic $\mathrm{Hg}$ and higher uptake of $\mathrm{MeHg}$ at the lower trophic levels in the river arm/side canyon/embayment sites of Lake Powell. This observation for plankton agrees with increases observed in particulate matter from the river arm/side canyon/embayment sites (p.MeHg.mass and p.THg.mass, appendix 2). As noted previously, enhanced bioaccumulation in river arm/side canyon/embayment sites is supported by the striped bass tissue samples collected in the San Juan Arm during 2014.

In the oligotrophic Lake Powell, the LSM-model results associated with surface water volumetric $\mathrm{Hg}$ species concentrations (appendix 2) associated with main stem and river arm/side canyon/embayment sites for f.MeHg, f.THg, volumetric particulate methylmercury (p.MeHg.vol), and volumetric particulate total mercury are much greater $(0.017$ and $0.026 \mathrm{ng} / \mathrm{L}], 0.310$ and $0.330 \mathrm{ng} / \mathrm{L}, 0.005$ and $0.009 \mathrm{ng} / \mathrm{L}$, and 0.140 and $0.140 \mathrm{ng} / \mathrm{L}$, respectively) than those observed for bulk plankton (bulk.MeHg.vol $5.1 \times 10^{-4}-1.74 \times 10^{-3} \mathrm{ng} / \mathrm{L}$

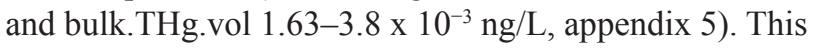
indicates that, on a volumetric basis, most of the $\mathrm{Hg}$ exists as dissolved or associated with particulates $<63 \mu \mathrm{m}$ (the lower limit of the plankton sampled via plankton net). However, from the perspective of uptake into the food web, particularly by zooplankton, volumetric $\mathrm{Hg}$ concentrations are likely less important than $\mathrm{Hg}$ concentrations on a gravimetric (weight) basis. By mass, the bulk plankton (material $>63 \mu \mathrm{m}$ ) was only 1.6 percent of the TSS mass $(>0.7 \mu \mathrm{m}$ fraction as assessed on filters) in river arm/side canyon/embayment sites and 1.2 percent in main stem sites, indicating that, by weight, the plankton $(>63 \mu \mathrm{m})$ are a small percentage of TSS for Lake Powell overall. Thus, by mass, much of the particulate $\mathrm{THg}$ and $\mathrm{MeHg}$ are associated with material between 0.7 and $63 \mu \mathrm{m}$, 
which represents a combination of organic particulates (algal or terrestrial detrital species $<63 \mu \mathrm{m}$ ) and inorganic silts and clays that are slow to sink out of the water column. Although we cannot discriminate the $\mathrm{Hg}$ contributions between the biotic and abiotic components in this size range, LSM organic content (as percent POC) for material $>0.7 \mu \mathrm{m}$ (collected on TSS filters) was 7.8 percent for the main stem and 10.3 percent for river arm/side canyon/embayment sites (appendix 2, not significantly different between these two spatial regions). Assuming a crude stoichiometry of $\mathrm{CH}_{2} \mathrm{O}$ for generic organic matter, this would indicate roughly 20 and 26 percent, respectively, of the particulate mass is organic in nature for the main stem and river arm/side canyon/embayment regions. Because $\mathrm{Hg}$ is more strongly associated with particulate organics, compared to inorganics, the general (nonsignificant) trend towards modestly higher organic content in the river arm/side canyon/embayment sites, compared with the main stem, may have outsized implications for $\mathrm{Hg}$ uptake into primary consumers and subsequent bioaccumulation in these two regions and could potentially drive higher fish $\mathrm{Hg}$ levels in those arm regions off the main stem.

Of particular note are the $\mathrm{Hg}$ concentrations measured in plankton collected from two narrow slot canyons (MarvinDiPasquale and others, 2017). The bulk.MeHg.mass concentrations of $59.2 \mathrm{ng} / \mathrm{g}$ (dry weight) and $62.0 \mathrm{ng} / \mathrm{g}$ (dry weight) measured from samples collected at West Canyon (LP-25-I) and $107.8 \mathrm{ng} / \mathrm{g}$ (dry weight) in Face Canyon (LP-26-P) were about 5-10 times higher than the LSM-modeled bulk.MeHg. mass concentrations reported for the main stem (12.6 \pm 3.0 , appendix 5). Similarly, bulk.THg.mass concentrations were elevated in West Canyon (101.2 ng/g [dry weight] and $109.3 \mathrm{ng} / \mathrm{g}$ [dry weight]) and Face Canyon (166.4 ng/g [dry weight]) and much higher than the LSM-modeled concentrations for the main stem (40.4 \pm 5.0 , appendix 5). Although there are no surface water data collected for Face Canyon, surface water p.MeHg.mass (10.9-17.9 ng/g) and \%p.MeHg (19.0-24.6 percent) at West Canyon also were the highest measured at any site. More research would be needed to determine if these particularly elevated $\mathrm{MeHg}$ concentrations in the plankton and water particulates are typical for these types of terminal/ephemeral side canyons (as opposed to embayments and river arms). However, given the quiescent conditions in these narrow and sheltered subhabitats, it can be hypothesized that this may be the case.

Among the various river arm/side canyon/embayment sites sampled across Lake Powell, West and Face Canyons represent the extreme endmember of morphological conditions. The sampling sites in these two side canyons were far removed from the main stem of Lake Powell (about $7 \mathrm{~km}$ from the mouth of the canyon), receiving only a seasonal source of freshwater input. These side canyons were relatively narrow $(<100 \mathrm{~m})$ but still relatively deep $(29 \mathrm{~m})$. Water-quality profiles measured depleted oxygen $(<\sim 2 \mathrm{mg} / \mathrm{L})$ in the hypolimnion and anoxia $(<0.5 \mathrm{mg} / \mathrm{L} \mathrm{DO})$ in the bottom $2 \mathrm{~m}$ (fig. 33). During water-quality sampling in West Canyon, samples collected at the thermocline and hypolimnion contained a strong sulfidic odor. Although sulfide was not measured in water samples, West Canyon was the only site where a sulfide odor was noted. Sulfide is an indication of sulfate-reducing bacteria activity and is one of the key microbial processes that results in the formation of $\mathrm{MeHg}$ in sediments and waters. Substantially elevated levels of f.MeHg and p.MeHg also were measured in the hypolimnion of West Canyon $(0.53 \mathrm{ng} / \mathrm{L}$ and $0.062 \mathrm{ng} / \mathrm{L}$, respectively). Although only a few side canyons were visited during the 2014/2015 synoptic sampling, narrow side canyons are a common feature in lower Lake Powell. Extremely elevated levels of $\mathrm{MeHg}$ production and uptake may exist in the narrow side canyons and support hypothesis 2.

Sediment.-Key sediment data (benthic microbial rate metrics) associated with hypothesis 2 included (1) calculated rates of MPP (on a dry weight and areal basis (both $p<0.10$ ), (2) calculated rates of MDP on a dry weight $(p<0.10)$ and an areal $(p<0.05)$ basis, and (3) net change in ambient $\mathrm{MeHg}$ concentration based on 1-day incubations $(p<0.05)$. All three of the benthic microbial rate metrics were consistently greater for main stem sites than for arm sites (appendix 3). This trend runs counter to hypothesis 2 in that $\mathrm{MeHg}$ production overall is greater in river arm/side canyon/embayment sites, compared to the main stem. Further, these trends in sediment microbial $\mathrm{Hg}$ transformations indicate more microbial activity overall in the main stem, compared to the side arm and canyon sites that were sampled.

Opposing trends between the sediment and water-column and plankton results indicate enhanced water-column $\mathrm{MeHg}$ production associated with particulates in river arm and side canyon sites, relative to main stem sites. Thus, the sediment data independent of water-column and plankton matrices cannot explain why striped bass $\mathrm{Hg}$ levels might be higher in river arm/side canyon/embayment sites, such as the San Juan Arm, compared to the upper or lower main stem areas of Lake Powell (fig. 3).

\subsection{Hypothesis 3 (Early Season Versus Late Season)}

Water.-Of the 41 water-column parameters, 25 exhibited a statistically significant $(p<0.05)$ seasonal difference between the early (May/June 2014) and late (August 2015) synoptic sampling results for all sites (main stem, river arms, side canyons, and embayments) (appendix 2). Detailed discussion on selected non-Hg and $\mathrm{Hg}$ parameters are presented below.

LSM-modeled dissolved nitrate $\left(\mathrm{NO}_{3}^{-}\right)$and phosphate $\left(\mathrm{PO}_{4}^{3-}\right)$ exhibited a significant $(p<0.05)$ decrease in concentration from the early season to the late season (appendix 2). This decrease in nutrient concentration in the water column during the late season likely reflects nutrient removal from the water column to support phytoplankton growth. Contour maps of $\mathrm{NO}_{3}{ }^{-}+\mathrm{NO}_{2}{ }^{-}$concentrations in the main stem support the statistical results and exhibit an overall decrease in late-season 


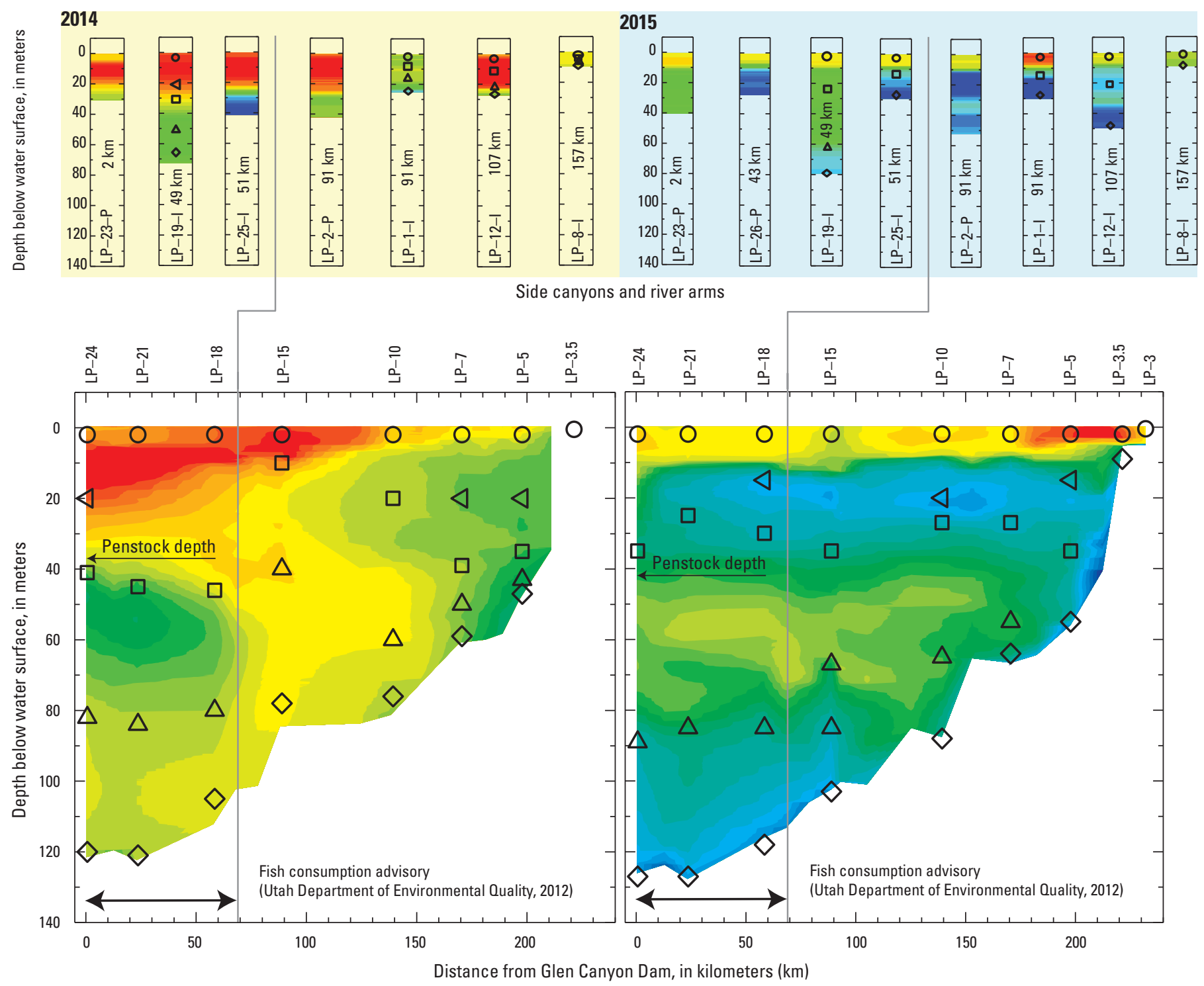

EXPLANATION

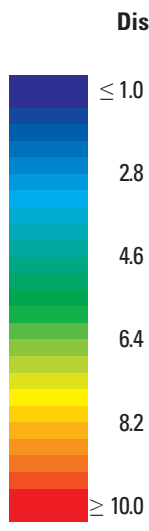

Figure 33. Comparison of dissolved oxygen, in milligrams per liter, profiles in the main stem and river arms, side canyons, and embayments of Lake Powell during the May/June 2014 and August 2015 synoptic sampling trips to the location of the fish consumption advisory, Glen Canyon National Recreation Area, Arizona and Utah. 
(2015) concentration (fig. 7). In support of nutrient removal as the causal mechanism, the LSM-modeled chl.a (lab) concentration exhibited a significant $(p<0.05)$ increase in concentration from the early-season to late-season synoptic sampling results (appendix 2). The observed increase in chl.a during the late-season synoptic sampling, combined with increasing reservoir stratification, as noted in hypothesis 3 , is the probable mechanism causing many of the statistically significant changes exhibited by other parameters including DO, fDOM, DIC, and $\mathrm{pH}$.

LSM-modeled DO (EXO 2 sonde) exhibited a significant $(p<0.05)$ decrease from $7.56 \pm 0.29 \mathrm{mg} / \mathrm{L}$ in 2014 (early-season synoptic sampling) to $5.15 \pm 0.27 \mathrm{mg} / \mathrm{L}$ in 2015 (late-season synoptic sampling). This trend is consistent with hypothesis 3 and the conceptual model where less stratified conditions are expected during the early-season synoptic sampling and more stratified conditions with lower hypolimnion DO concentrations are expected during the late-season synoptic sampling. When strongly stratified conditions are established, this allows for the accumulation, isolation, and decay of organic particles in certain areas of the reservoir. During the late-season synoptic sampling, areas of oxygen depletion in the water column at depths of 20 to $30 \mathrm{~m}$ below the reservoir surface are likely due to the decomposition of phytoplankton accumulating on the chemocline (fig. 33). Johnson and Merritt (1979) noted that partial convective overturn in Lake Powell during the fall results in the descent of this oxygen-depleted water into the hypolimnion, likely resulting in more intense and widespread suboxic regions. In contrast, the early-season synoptic sampling of DO concentration profiles (fig. 33) provide evidence for the regeneration of low DO concentration areas as a result of the plunging of cold, oxygen-enriched waters starting in the winter as an underflow density current associated with inflows from the San Juan and Colorado Rivers (Johnson and Merritt, 1979). Areas with low ( $<2 \mathrm{mg} / \mathrm{L})$ DO concentrations during the late-season synoptic sampling also were observed in the water column directly above the reservoir bottom in the lower main stem (0 to $90 \mathrm{~km}$ above Glen Canyon Dam) and in selected river arm/side channel/embayment sites (fig. 33).

LSM-modeled fDOM exhibited a significant $(p<0.05)$ increase from early-season ( $5.74 \pm 0.58 \mathrm{RFUs})$ to late-season (8.62 \pm 0.87 RFUs) (appendix 2) synoptic sampling cruises. Elevated fDOM values in Lake Powell during the late-season synoptic sampling were coincident with the low DO zones in the main stem and river arm/side channel/embayment sites (figs. 15 and 33). Elevated fDOM plume ( $>19$ RFUs) in the main stem ranged in depth from $\sim 30 \mathrm{~m}$ below the water surface (upper reservoir) to $\sim 18 \mathrm{~m}$ below the water surface (lower reservoir). Decomposition of phytoplankton accumulating on the chemocline in the main stem would presumably result in the observed increase in fDOM and low DO conditions in this zone during the late season. The fDOM concentrations in selected river arm/side channel/embayment sites also were elevated during the late season (fig. 15). In contrast to the spatial trends in fDOM, the LSM-modeled dissolved organic carbon (DOC [Denver] in appendix 2) concentrations and specific ultraviolet absorption at $254 \mathrm{~nm}$ (SUVA [Denver] in appendix 2) do not indicate a significant difference between early- and late-season sampling periods (appendix 2). Although bulk DOC concentrations did not indicate significant seasonal differences, the seasonal shifts in fDOM indicate seasonal shifts in some part of the total DOM pool, because fDOM is reflective of just a small part of total DOM.

LSM-modeled $\mathrm{pH}$ exhibited a significant $(p<0.05)$ decrease from the early- $(8.01 \pm 0.04$ units $)$ to late(7.88 \pm 0.04 units) season synoptic sampling (appendix 2) and also is consistent with the more stratified conditions during the late-season synoptic sampling predicted by hypothesis 3 . The lower late-season $\mathrm{pH}$ is likely from phytoplankton accumulation on the chemocline under stratified conditions and the decay resulting in the generation of higher partial pressures of $\mathrm{CO}_{2}$ (g) causing lower $\mathrm{pH}$ values. In contrast, elevated $\mathrm{pH}$ values and DO concentrations are observed in the epilimnion during the early- and late-season synoptic sampling (figs. 13 and 33 ), likely resulting from the higher primary productivity in the photic zone resulting in lower partial pressures of $\mathrm{CO}_{2}(\mathrm{~g})$ and increasing concentrations of DO. Elevated $\mathrm{pH}$ values in the epilimnion are only observed in the lower one-half of the reservoir during the early-season synoptic sampling, likely resulting from the higher TURB (fig. 14) and limited light penetration in the upper one-half of the reservoir.

Many of the $\mathrm{Hg}$ parameters measured in the water column indicated statistically significant $(p<0.05)$ trends between measured early- and late-season concentrations (appendix 2) and are consistent with hypothesis 3. LSM-modeled f.MeHg and f.THg exhibited a statistically significant, yet small ( $<30$ percent) increase between the early- and late-season sampling periods. In addition, p.MeHg.mass and p.THg.mass, and $\%$ p. $\mathrm{MeHg}$, all exhibited a significant increase from the early to the late season (appendix 2).

The elevated late-season concentration of filter-passing and particulate $\mathrm{MeHg}$ in the water column is consistent with the conceptual model, which proposes the linkage between increased phytoplankton production leading to higher rates of heterotrophic microbial activity in the water column and subsequently enhanced $\mathrm{Hg}$ (II)-methylation in the water column. As discussed previously, numerous non- $\mathrm{Hg}$ parameters $\left(\mathrm{NO}_{3}^{-}\right.$, $\mathrm{PO}_{4}{ }^{3-}, \mathrm{DO}, \mathrm{fDOM}$, and $\mathrm{pH}$ ) also support the inferred increase in early-season phytoplankton production that leads to decay during the late-season synoptic sampling.

Plankton.-Of the seven bulk plankton parameters, six exhibited statistically significant $(p<0.05)$ differences between the early- and late-season synoptic sampling trips (appendix 5) and are supportive of hypothesis 3. Overall, plankton biomass (as milligrams per liter and as percent of TSS dry weight) was significantly higher during the early season compared to the late season, indicating a potential zooplankton bloom after the initial spring phytoplankton bloom brought about by higher flows and nutrient inputs. The early season also exhibited a significantly higher bulk plankton percent methylmercury concentration in plankton, compared to the late season. This trend was largely driven by significantly higher gravimetric $\mathrm{THg}$ 
(bulk.THg.mass) in the late season, and not by higher concentrations of $\mathrm{MeHg}$ (bulk.MeHg.mass) in the early season, in the bulk plankton. No significant difference in bulk.MeHg.mass was observed between the early- and late-season synoptic sampling trips (appendix 5). The early- to late-season decrease in both types of bulk plankton volumetric $\mathrm{Hg}$ (bulk.MeHg. vol and bulk.THg.vol) reflect the overall parallel decrease in plankton biomass. As noted previously in section 3.2, "Biota," because of the oligotrophic nature of Lake Powell, bulk.MeHg.vol and bulk.THg.vol concentrations are a minor fraction $(<10 \%$ for $\mathrm{MeHg}$ and $<1 \%$ for $\mathrm{THg}$ ) of the total $\mathrm{Hg}$ pool in the water column. However, the observed changes in plankton $\mathrm{Hg}$ mass/volume concentrations are relatively large (5-6 fold). Considering that plankton is at the base of the food web, an increased abundance of plankton-associated $\mathrm{Hg}$ in the water column may lead to increased incorporation into the food web in the early season.

Sediment.-There were a number of interesting trends in the surface sediment data that point to key seasonal differences that support hypothesis 3 . These seasonal differences include $\mathrm{Hg}$ (II) availability for methylation and the activity of the benthic microbial community overall and microbial $\mathrm{Hg}(\mathrm{II})$-methylation specifically. The first of these observations is associated with RHg concentration (and RHg normalized to LOI), which was higher in the early season compared to the late season (appendix 3). This would indicate that $\mathrm{Hg}$ (II) is generally more available for $\mathrm{Hg}$ (II)-methylation earlier in the year, before strong water-column stratification and the onset of strong hypoxic or anoxic bottom water/more reduced surface sediment conditions. This trend is consistent with previously published results that indicate RHg decreases as sediment conditions become more reducing (Marvin-DiPasquale and others, 2009a; Marvin-DiPasquale and Cox, 2007; MarvinDiPasquale and others, 2009b; Marvin-DiPasquale and others, 2014). Although the difference in surface sediment redox $\left[\mathrm{E}_{\mathrm{h}}\right]$ was not statistically different between the two sampling events, the trend in the LSM ( \pm standard error) was consistent with the early period ( $65.2 \pm 16.6$ millivolts $[\mathrm{mv}])$ being somewhat more oxidized than the late period $(26.2 \pm 15.3 \mathrm{mv})$ (appendix 3), although variability among individual sampling sites was high.

The second set of observations indicates that microbial activity overall, and microbial $\mathrm{Hg}$ (II)-methylation specifically, is greater during the late period, compared with the early period. Specifically, 16S rRNA gene abundance was significantly greater in August, as was the LSM-modeled rate constant associated with $\mathrm{MeHg}$ production $\left(\mathrm{k}_{\text {meth }}\right)$ (appendix 3). Both of these microbial rate and production metrics are commonly affected by temperature, which also was significantly more elevated during August (appendix 3). Finally, the sediment $\%$.MeHg metric, commonly considered a proxy for $\mathrm{Hg}(\mathrm{II})$-methylation efficiency (Gilmour and others, 1998; Krabbenhoft and others, 1999; Sunderland and others, 2006), also was significantly elevated during the late-season synoptic sampling (appendix 3). In addition to temperature, the seasonal shift from oxic to hypoxic-anoxic conditions in the bottom waters and surface sediment, conditions favor anaerobic microbial processes (microbial sulfate and iron reduction) that are key drivers of MeHg formation. This shift in redox likely also plays an important role in the observed increased $\mathrm{k}_{\text {meth }}$ and $\% \mathrm{MeHg}$ from early to late season. Although sediment redox $\left(\right.$ as $\left.\mathrm{E}_{\mathrm{h}}\right)$ was not statistically significantly different between the early and the late season across all sites, the trend was towards more reducing conditions during the late season (appendix 3). As surface sediments become more reducing, the proportion of inorganic $\mathrm{Hg}$ (II) available for $\mathrm{Hg}$ (II)-methylation (measured as RHg) tends to decrease (Marvin-DiPasquale and Cox, 2007; Marvin-DiPasquale and others, 2009a, 2009b, 2014). Taken together, this suite of observations supports the conceptual model, which proposes that there is a seasonal shift from the period beginning stratification (early-season synoptic sampling), when the availability of $\mathrm{Hg}$ (II) exerts a primary control on MeHg production, to late summer (late-season synoptic sampling), when microbial activity is a dominant driver of $\mathrm{MeHg}$ production.

\subsection{Implications of Study Results and Future Study Needs}

The main goal of scientific studies associated with the USGS/NPS Water Quality Partnership program is to provide results to guide policy and management actions by the NPS that are aimed at protecting and improving water quality within NPS-administered lands (Nilles and others, 2016). The approach used in the current study coupled fish survey data with the sampling of $\mathrm{Hg}$ and non-Hg constituents in water, plankton, and sediments to obtain a process-level understanding of temporal and spatial $\mathrm{Hg}$ dynamics within Lake Powell. With respect to management actions, the results from this study support the earlier conclusions by the fish surveys completed by the State of Utah in Lake Powell, which led to the 2012 striped bass consumption advisory in the lower part of the system. Importantly, the results capture the processes that drive the spatial trends observed, which are related to the upstream to downstream changes in water-column particulate concentrations and composition that result in more effective transfer of MeHg into the base of the food web in the downstream part of the system and in side canyons/river arms. The results provide only preliminary information on temporal trends, because only two synoptic surveys were completed, and more information is needed. Thus, future policy and management actions directed towards $\mathrm{Hg}$ issues need to recognize these processes and consider how they are related to overall reservoir management, such as regulating the amount and timing of water moving through the system.

Important work remains to be done in Lake Powell related to temporal trends, geographic and habitat types, and the relative contribution of sediment versus water-column methylation. More intensive temporal sampling needs to be part of any future study. This will help to illuminate when 
during the annual hydrologic cycle the transfer of $\mathrm{MeHg}$ into the base of the food web is more or less important and how these temporal considerations are linked to hydrology, nutrient loading, stratification, and lower food-web trophic dynamics. Future study needs to include assessing the geographic and habitat types within Lake Powell that likely present the highest $\mathrm{Hg}$ risk; for example, detailed assessments of $\mathrm{Hg}$ (II)methylation and the associated biogeochemistry in selected side canyons that exhibit seasonal anoxia are needed. Fish use statistics associated with side canyon and river arm habitats in Lake Powell need to be investigated to determine if these areas are important to striped bass and other fish species. Determining the relative contribution of sediment versus water-column methylation will help to better understand and predict how changes in reservoir chemistry will affect $\mathrm{Hg}$ biomagnification.

The results of our study also provide a basis for the identification and evaluation of remediation activities related to Hg. The results indicate that more limited geographic areas within Lake Powell (for example, side canyons and river arms) could be targeted for active remediation strategies, if deemed necessary. Pumping-induced, artificial circulation in targeted areas within lakes and reservoirs has recently been suggested as a method for remediation of $\mathrm{Hg}$ and other water-quality constituents (Hudnell, 2010). Recent work in Finland (Verta and others, 2010; Rask and others, 2010) has determined that pumping-induced, within-lake thermocline/oxycline manipulation was achievable using a small pump. The 1.5 to $2.0 \mathrm{~m}$ depression of the thermocline achieved during the 2 years of pumping resulted in a significant decrease in $\mathrm{MeHg}$ concentrations in water and small perch. Other potential strategies to lower $\mathrm{MeHg}$ concentrations in reservoirs and lakes include adding selenium, lime, or phosphorus and capping and dredging bottom sediment (Mailman and others, 2006).

\section{Summary}

Lake Powell is a large and critical western U.S. reservoir (water volume $=3.3 \times 10^{10}$ cubic meters) in southeastern Utah and northern Arizona with important water storage, power generation, and recreational uses. Results of mercury (Hg) monitoring of about 300 Morone saxatilis (striped bass) muscle tissue samples collected from Lake Powell from 2005 to 2012 resulted in the issuance of a joint fish consumption advisory below Dangling Rope Marina by Arizona and Utah during 2012. A process-driven conceptual model was proposed and tested to explain the persistence of elevated $\mathrm{Hg}$ in fish tissue samples collected from the lower (0 to 100 kilometers above Glen Canyon Dam) part of Lake Powell. Important features of the conceptual model include limited light penetration in the upper reservoir because of dominant inorganic particles, increased light penetration in the lower reservoir from the settling of inorganic particles resulting in increased phytoplankton production, and enhanced phytoplankton decomposition in the lower reservoir supporting areas of hypoxic/anoxic conditions and microbial methylmercury ( $\mathrm{MeHg}$ ) production. Oxygen depletion in the metalimnion was documented in the main stem of the reservoir in a previous study and resulted from the accumulation of senescent phytoplankton within the chemocline.

Data collected during two synoptic sampling cruises on Lake Powell during May/June 2014 (early season) and August 2015 (late season) were used to test three hypotheses developed from the conceptual model. The testable hypotheses proposed that there were measurable differences in key $\mathrm{Hg}$ and non-Hg metrics between (hypothesis 1) the upper and lower reservoir, (hypothesis 2) main stem and river arm/side canyon/ embayment sites, and (hypothesis 3) early-season (less stratified) and late-season (stratified) conditions. Hypotheses were tested using least square mean (LSM) models in combination with graphical displays of $\mathrm{Hg}$ and non- $\mathrm{Hg}$ metrics to examine surface water, sediment, plankton, and fish data collected during the study. Data collected during the study are included in a U.S. Geological Survey data release at https://doi.org/10.5066/ F74X560J.

For hypothesis 1, 20 of the 45 water-column parameters exhibit a significant $(p<0.05)$ difference between the upper and lower regions of the reservoir. The LSM for turbidity was higher in the upper reservoir and was consistent with hypothesis 1 . Higher (probability $[p]$ less than $[<] 0.05$ ) LSM values for gravimetric particulate methylmercury (p.MeHg.mass), aqueous-particulate partitioning coefficient for methylmercury $\left(\mathrm{K}_{\mathrm{d}}[\mathrm{MeHg}]\right)$, aqueous-particulate partitioning coefficient for total mercury $\left(\mathrm{K}_{\mathrm{d}}[\mathrm{THg}]\right)$, and the percent of particulate methylmercury in the lower reservoir were determined. Further, planktonic gravimetric bulk plankton total mercury concentration (bulk.THg.mass) was significantly $(p<0.05)$ higher and gravimetric bulk plankton methylmercury concentration (bulk.MeHg.mass) trended higher (not statistically significant) in the lower reservoir. Both of these plankton metrics are supportive of hypothesis 1 and indicate enhanced bioavailability of $\mathrm{Hg}$ in plankton from the lower reservoir. Also in support of hypothesis 1 , higher $\mathrm{MeHg}$ production in near-surface sediment collected from the lower regions of the reservoir was observed for a number of metrics, including net $\mathrm{MeHg}$ production and methylmercury production potential rates. The LSMs for the surface sediment variables including mercury-methylation rate constant $\left(\mathrm{k}_{\text {meth }}\right)$, methylmercury as a percentage of total mercury ( $\% \mathrm{MeHg})$, and $\mathrm{MeHg}$ concentration were higher in the lower reservoir; however, these differences were not statistically significant.

For hypothesis 2, 11 of the 45 water-column parameters exhibit a statistically significant $(p<0.05)$ difference between the main stem and river arm/side canyon/embayment sites in Lake Powell. Chief among these, p.MeHg.mass, gravimetric particulate total mercury, and percent of particulate methylmercury were all significantly $(p<0.05)$ higher in the river arm/side canyon/embayment sites compared to the reservoir main stem. Significant $(p<0.05)$ non-Hg water-column metrics in support of hypothesis 2 included elevated ammonia $\left(\mathrm{NH}_{4}^{+}\right)$ 
and low nitrate $\left(\mathrm{NO}_{3}{ }^{-}\right)$concentrations in the river arm/side canyon/embayment sites that also coincide with the distribution of low dissolved oxygen (DO) concentrations in these areas. Of the 11 plankton metrics, 10 exhibited significant $(p<0.05)$ or weakly significant $(p<0.10)$ differences between main stem and river arm/side canyon/embayment sites. $\mathrm{MeHg}$ specific plankton parameters supporting hypothesis 2 (higher concentrations or masses in river arm/side canyon/embayment sites) included \%.MeHg, plankton methylmercury concentration (gravimetric, individual size fraction), plankton methylmercury concentration (volumetric, individual size fraction) bulk.MeHg.mass, and volumetric bulk plankton methylmercury concentration. All three benthic microbial rate metrics (methylmercury production potential, methylmercury degradation potential, and ambient net $\mathrm{MeHg}$ production) for surface sediment samples were consistently greater $(p<0.05$ or $p<0.10$ ) for main stem sites than for river arm/side canyon/ embayment sites and were counter to hypothesis 2 . These sediment trends also were in contrast with the above spatial trends for water-column plankton MeHg metrics. Thus, to the extent that $\mathrm{Hg}$ accumulation in top level fish in Lake Powell is associated with a pelagic dominant food web, this indicates that the trends in sediment $\mathrm{MeHg}$ production have little direct effect on upper water-column MeHg concentrations. Enhanced bioaccumulation in the arm sites is supported by the elevated $\mathrm{Hg}$ detected in length normalized striped bass muscle tissue samples collected in the San Juan Arm during this study. Fish collected from the lower reservoir (Wahweap Bay) also exhibited a distinct $\mathrm{Hg}$ isotopic signature that was enriched in delta $(\delta)^{202} \mathrm{Hg}$ and capital delta $(\Delta)^{199} \mathrm{Hg}$ relative to fish samples collected from Good Hope Bay or the San Juan Arm. The isotopic evidence indicates that the $\mathrm{MeHg}$ accumulated in these upper trophic level fish from the three sites sampled is consistent with $\mathrm{MeHg}$ originally produced in surface sediment, because the fish and sediment isotopes fall along the same mixing line. However, because sediment sampled from other locations within Lake Powell are generally more depleted in the $\delta^{202} \mathrm{Hg}$, this indicates that $\mathrm{MeHg}$ produced in the water column may also contribute significantly to the $\mathrm{MeHg}$ in sportfish. More study is needed to resolve the relative importance of sediment versus the water column as the zone of $\mathrm{MeHg}$ production that is ultimately incorporated into the Lake Powell pelagic food web and upper trophic level fish.

Of the 41 water-column metrics associated with hypothesis 3, 25 exhibited a significant $(p<0.05)$ seasonal difference between the early- and late-season synoptic sampling. Non- $\mathrm{Hg}$ parameters with significant seasonal differences supportive of hypothesis 3 included $\mathrm{NO}_{3}^{-}$, orthophosphate $\left(\mathrm{PO}_{4}^{3-}\right)$, chlorophyll $a$ (chl.a), DO (EXO 2 sonde), fluorescent dissolved organic matter, and $\mathrm{pH}$. These non-Hg metrics indicate that, relative to the early season, the late season is a period of higher phytoplankton biomass overall, driving lower nutrient levels, enhanced heterotrophic microbial activity associated with phytoplankton decomposition, lower DO concentrations, and stratified conditions. However, the high-resolution water-quality profiling data indicate a chl.a maximum during the early season in the upper water column at the downstream end of Lake Powell, indicating that this may be an important period of MeHg transfer into the base of the food web in the region of the system that is of most concern with respect to elevated fish $\mathrm{Hg}$ concentrations. Phytoplankton production and remineralization in the upper water column also are evident by the increasing dissolved inorganic carbon (DIC) and decreasing particulate organic carbon with water-column depth, as well as enriched $\delta^{13} \mathrm{C}$-DIC in surface water and increasing $\mathrm{NO}_{3}{ }^{-}$with depth. Overall, these data reveal a dynamic situation with respect to primary and secondary plankton production, which is affected by turbidity and nutrient loading to the reservoir, and phytoplankton production is highest in the lower reservoir during the early season and highest in the upper reservoir during the late season.

Water-column Hg metrics that support hypothesis 3, included filter-passing methylmercury, filter-passing total mercury, p.MeHg.mass, and gravimetric particulate total mercury, all of which significantly $(p<0.05)$ increased from the early to the late season. Plankton parameters that also exhibited a significant increase between the early- and lateseason sampling cruises included b.MeHg.mass, b.THg.mass, and bulk.THg.mass. Key seasonal differences supportive of hypothesis 3 also were observed in key surface sediment data; for example, ribosomal ribonucleic acid, small subunit 16 (16S rRNA) gene abundance and the rate constant associated with $\mathrm{MeHg}$ production $\left(\mathrm{k}_{\text {meth }}\right)$ were significantly greater during the late-season synoptic sampling cruise. The combined surface sediment metrics were supportive of a seasonal shift from the early-season synoptic sampling, when the availability of $\mathrm{Hg}$ (II) exerted a primary control on $\mathrm{MeHg}$ production, to the late-season synoptic sampling, when microbial activity was a dominant driver of $\mathrm{MeHg}$ production.

Future data collection and associated research needs to focus on the geographic and habitat types within Lake Powell that likely present the highest Hg risk, such as the river arms and side canyons. If necessary, these specific areas within Lake Powell could be targeted for active remediation strategies such as pumping-induced thermocline manipulation, which has been successful in smaller lake systems for Hg remediation. 


\section{References Cited}

Arizona Department of Environmental Quality, 2012, Arizona and Utah announce fish consumption advisory for mercury in southern Lake Powell: Arizona Department of Environmental Quality press release, accessed February 27, 2018, at http://legacy.azdeq.gov/function/news/2012/ download/102512.pdf.

Arizona Leisure, 2012, Lake Powell facts: Arizona Leisure web page, accessed December 6, 2012, at https://www.arizona-leisure.com/lake-powell-facts.html.

Bengtsson, G., and Picado, F., 2008, Mercury sorption to sediments - Dependence on grain size, dissolved organic carbon, and suspended bacteria: Chemosphere, v. 73, no. 4, p. 526-531. [Also available at https://doi.org/10.1016/ j.chemosphere.2008.06.017.]

Bergquist, B.A., and Blum, J.D., 2007, Mass-dependent and -independent fractionation of $\mathrm{Hg}$ isotopes by photoreduction in aquatic systems: Science, v. 318, no. 5849, p. 417-420. [Also available at https://doi.org/10.1126/science.1148050.]

Blinn, D.W., Tompkins, T., and Stewart, A.J., 1976, Seasonal light characteristics for a newly formed reservoir in southwestern USA: Hydrobiologia, v. 51, no. 1, p. 77-84. [Also available at https://doi.org/10.1007/BF00007988.]

Brigham, M.E., Krabbenhoft, D.P., and Hamilton, P.A., 2003, Mercury in stream ecosystems - New studies initiated by the U.S. Geological Survey: U.S. Geological Survey Fact Sheet 016-03, 4 p.

Chalmers, A., Marvin-DiPasquale, M.C., Degnan, J.R., Coles, J., Agee, J.L., and Luce, D., 2013, Characterization of mercury contamination in the Androscoggin River, Coos County, New Hampshire: U.S. Geological Survey OpenFile Report 2013-1076, 58 p., accessed December 2017 at https:/pubs.usgs.gov/of/2013/1076/.

Colman, D.R., Feyhl-Buska, J., Robinson, K.J., Fecteau, K.M., Xu, H., Shock, E.L., and Boyd, E.S., 2016, Ecological differentiation in planktonic and sediment-associated chemotrophic microbial populations in Yellowstone hot springs: FEMS Microbiology Ecology, v. 92, no. 10, p. fiw168. [Also available at https://doi.org/10.1093/femsec/fiw168.]

Compeau, G.C., and Bartha, R., 1984, Methylation and demethylation of mercury under controlled redox, $\mathrm{pH}$, and salinity conditions: Applied and Environmental Microbiology, v. 48, no. 6, p. 1203-1207. [Also available at https://www.ncbi.nlm.nih.gov/pmc/articles/PMC241710/ pdf/aem00157-0145.pdf.]
Compeau, G.C., and Bartha, R., 1985, Sulfate-reducing bacteria-Principal methylators of mercury in anoxic estuarine sediment: Applied and Environmental Microbiology, v. 50, no. 2, p. 498-502. [Also available at https://www.ncbi.nlm.nih.gov/pmc/articles/PMC238649/ pdf/aem00143-0322.pdf.]

Downing, B.D., Pellerin, B.A., Bergamaschi, B.A., Saraceno, J.F., and Kraus, T.E.C., 2012, Seeing the light-The effects of particles, dissolved materials, and temperature on in situ measurements of DOM fluorescence in rivers and streams: Limnology and Oceanography, v. 10, no. 10, p. 767-775. [Also available at https://doi.org/10.4319/lom.2012.10.767.]

Eagles-Smith, C.A., Ackerman, J.T., Willacker, J.J., Tate, M.T., Lutz, M.A., Fleck, J.A., Stewart, A.R., Wiener, J.G., Evers, D.C., Lepak, J.M., Davis, J.A., and Pritz, C.F., 2016, Spatial and temporal patterns of mercury concentrations in freshwater fish across the Western United States and Canada: Science of the Total Environment, v. 568, p. 1171-1184. [Also available at https://doi.org/10.1016/ j.scitotenv.2016.03.229.]

Eckley, C.S., and Hintelmann, H., 2006, Determination of mercury methylation potentials in the water column of lakes across Canada: Science of the Total Environment, v. 368, no. 1, p. 111-125. [Also available at https://doi. org/10.1016/j.scitotenv.2005.09.042.]

Gascón Díez, E., Loizeau, J.L., Cosio, C., Bouchet, S., Adatte, T., Amouroux, D., and Bravo, A.G., 2016, Role of settling particles on mercury methylation in the oxic water column of freshwater systems: Environmental Science \& Technology, v. 50, no. 21, p. 11672-11679. [Also available at https://doi.org/10.1021/acs.est.6b03260.]

Gilmour, C.C., Riedel, G.S., Ederington, M.C., Bell, J.M., Gill, G.A., and Stordal, M.C., 1998, Methylmercury concentrations and production rates across a trophic gradient in the northern Everglades: Biogeochemistry, v. 40, no. 2-3, p. 327-345. [Also available at https://doi.org/10.1023/A:1005972708616.]

Gloss, S.P., 1977, Application of the nutrient loading concept to Lake Powell, the effects of nutrient perturbations on phytoplankton productivity, and levels of nitrogen and phosphorus in the reservoir: University of New Mexico, Ph.D. dissertation, $225 \mathrm{p}$.

Gloss, S.P., Mayer, L.M., and Kidd, D.E., 1980, Advective control of nutrient dynamics in the epilimnion of a large reservoir: Limnology and Oceanography, v. 25, no. 2, p. 219-228. [Also available at https://doi.org/10.4319/ 1o.1980.25.2.0219.] 
Gloss, S.P., Reynolds, R.C., Jr., Mayer, L.M., and Kidd, D.E., 1981, Reservoir influences on salinity and nutrient fluxes in the arid Colorado River Basin, in Stefan, H.G., ed., Proceedings of the Symposium on Surface Water Impoundments: New York, American Society of Civil Engineers, p. 1618-1629.

Graf, W.L., 1985, Mercury transport in stream sediments of the Colorado Plateau: Annals of the Association of American Geographers, v. 75, no. 4, p. 552-565. [Also available at https://doi.org/10.1111/j.1467-8306.1985.tb00093.x.]

Graham, A.M., Aiken, G.R., and Gilmour, C.C., 2012, Dissolved organic matter enhances microbial mercury methylation under sulfidic conditions: Environmental Science \& Technology, v. 46, no. 5, p. 2715-2723. [Also available at https://doi.org/10.1021/es203658f.]

Hart, R.J., and Sherman, K.M., 1996, Physical and chemical characteristics of Lake Powell at the forebay and outflows of Glen Canyon Dam, northeastern Arizona, 1990-91: U.S. Geological Survey Water-Resources Investigations Report 96-4016, 83 p.

Hart, R.J., Taylor, H.E., Antweiler, R.C., Graham, D.D., Fisk, G.G., Riggins, S.G., and Flynn, M.E., 2005, Sediment chemistry of the Colorado River delta of Lake Powell, Utah, 2001: U.S. Geological Survey Open-File Report 2005-1178, $33 \mathrm{p}$.

Hudnell, H.K., 2010, Within water-body management-A needed but neglected complement to watershed management: Clean Technologies and Environmental Policy, v. 12, no. 3, p. 205-207. [Also available at https://doi.org/10.1007/ s10098-010-0304-6.]

Johnson, N.M., and Merritt, D.H., 1979, Convective and advective circulation of Lake Powell, Utah-Arizona, during 1972-1975: Water Resources Research, v. 15, no. 4, p. 873-884. [Also available at https://doi.org/10.1029/ WR015i004p00873.]

Johnson, N.M., and Page, F.W., 1981, Oxygen depleted waters - Origin and distribution in Lake Powell, Utah-Arizona, in Stefan, H.G., ed., Proceedings of the Symposium on Surface Water Impoundments: New York, American Society of Civil Engineers, p. 1630-1637.

Kelly, C.A., Rudd, J.W.M., and Holoka, M.H., 2003, Effect of $\mathrm{pH}$ on mercury uptake by an aquatic bacterium-Implications for Hg cycling: Environmental Science \& Technology, v. 37, no. 13, p. 2941-2946. [Also available at https://doi.org/10.1021/es026366o.]
Kerin, E.J., Gilmour, C.C., Roden, E., Suzuki, M.T., Coates, J.D., and Mason, R.P., 2006, Mercury methylation by dissimilatory iron-reducing bacteria: Applied and Environmental Microbiology, v. 72, no. 12, p. 7919-7921. [Also available at https://doi.org/10.1128/AEM.01602-06.]

Krabbenhoft, D.P., Wiener, J.G., Brumbaugh, W.G., Olson, M.L., DeWild, J.F., and Sabin, T.J., 1999, A national pilot study of mercury contamination of aquatic ecosystems along multiple gradients, in Morganwalp, D.W., and Buxton, H.T., eds., U.S. Geological Survey Toxic Substances Hydrology Program-Proceedings of the Technical Meeting, Charleston, S.C., March 8-12, 1999, v. 2-Contamination of hydrologic systems and related ecosystems: U.S. Geological Survey Water-Resources Investigations Report 99-4018-B, p. 147-160.

Mailman, M., Stepnuk, L., Cicek, N., and Bodaly, R.A., 2006, Strategies to lower methyl mercury concentrations in hydroelectric reservoirs and lakes-A review: Science of the Total Environment, v. 368, no. 1, p. 224-235. [Also available at https://doi.org/10.1016/j.scitotenv.2005.09.041.]

Marvin-DiPasquale, M., and Agee, J.L., 2003, Microbial mercury cycling in sediments of the San Francisco Bay-Delta: Estuaries, v. 26, no. 6, p. 1517-1528. [Also available at https://doi.org/10.1007/BF02803660.]

Marvin-DiPasquale, M., Agee, J., Bouse, R., and Jaffe, B., 2003, Microbial cycling of mercury in contaminated pelagic and wetland sediments of San Pablo Bay, California: Environmental Geology, v. 43, no. 3, p. 260-267. [Also available at https://doi.org/10.1007/s00254-002-0623-y.]

Marvin-DiPasquale, M., Agee, J.L., Kakouros, E., Kieu, L.H., Fleck, J.A., and Alpers, C.N., 2011, The effects of sediment and mercury mobilization in the South Yuba River and Humbug Creek confluence area, Nevada County, California-Concentrations, speciation, and environmental fatePart 2-Laboratory experiments: U.S. Geological Survey Open-File Report 2010-1325B, 54 p.

Marvin-DiPasquale, M., Agee, J., McGowan, C., Oremland, R.S., Thomas, M., Krabbenhoft, D., and Gilmour, C., 2000, Methyl-mercury degradation pathways-A comparison among three mercury-impacted ecosystems: Environmental Science \& Technology, v. 34, no. 23, p. 4908-4916. [Also available at https://doi.org/10.1021/es0013125.]

Marvin-DiPasquale, M.C., Alpers, C.N., and Fleck, J.A., 2009b, Mercury, methylmercury, and other constituents in sediment and water from seasonal and permanent wetlands in the Cache Creek Settling Basin and Yolo Bypass, Yolo County, California, 2005-06: U.S. Geological Survey Open-File Report 2009-1182, 82 p. 
Marvin-DiPasquale, M.C., and Cox, M.H., 2007, Legacy mercury in Alviso Slough, south San Francisco Bay, California - Concentration, speciation and mobility: U.S. Geological Survey Open-File Report 2007-1240, 99 p.

Marvin-DiPasquale, M., Lutz, M.A., Brigham, M.E., Krabbenhoft, D.P., Aiken, G.R., Orem, W.H., and Hall, B.D., 2009a, Mercury cycling in stream ecosystems - 2-Benthic methylmercury production and bed sediment-Pore water partitioning: Environmental Science \& Technology, v. 43, no. 8, p. 2726-2732. [Also available at https://doi.org/10.1021/es802698v.]

Marvin-DiPasquale, M.C., Lutz, M.A., Krabbenhoft, D.P., Aiken, G.R., Orem, W.H., Hall, B.D., DeWild, J.F., and Brigham, M.E., 2008, Total mercury, methylmercury, methylmercury production potential, and ancillary streambed-sediment and pore-water data for selected streams in Oregon, Wisconsin, and Florida, 2003-04: U.S. Geological Survey Data Series 375, 25 p.

Marvin-DiPasquale, M.C., Naftz, D.L., Krabbenhoft, D.P., Anderson, M., Boyd, E.S., Aiken, G.R., Conaway, C.H., Ogorek, J.M., Poulin, B.A., Fuller, C.C., Antweiler, R.C., and Stricker, C.A., 2017, Data for biogeochemical and physical processes controlling mercury methylation and bioaccumulation in Lake Powell, Glen Canyon National Recreation Area, Utah and Arizona, 2014-2015: U.S. Geological Survey data release, https://doi.org/10.5066/F74X560J.

Marvin-DiPasquale, M., Windham-Myers, L., Agee, J.L., Kakouros, E., Kieu, L.H., Fleck, J., Alpers, C.N., and Stricker, C., 2014, Methylmercury production in sediment from agricultural and non-agricultural wetlands in the Yolo Bypass, California, USA: Science of the Total Environment, v. 484, p. 288-299. [Also available at https://doi.org/10.1016/ j.scitotenv.2013.09.098.]

Miller, M.P., 2012, The influence of reservoirs, climate, land use and hydrologic conditions on loads and chemical quality of dissolved organic carbon in the Colorado River: Water Resources Research, v. 48, no. 12, W00M02. [Also available at https://doi.org/10.1029/2012WR012312.]

National Park Service, 2012a, Fishing in Glen Canyon National Recreation Area: National Park Service web page, accessed March 10, 2017, at https://www.nps.gov/glca/ planyourvisit/fishing.htm.

National Park Service, 2012b, Endangered fish recovery in Glen Canyon National Recreation Area: National Park Service web page, accessed April 27, 2018, at https://www.nps.gov/glca/naturescience/endangeredfish. htm.

National Research Council, 1996, River resource management in the Grand Canyon: Washington, D.C., National Academies Press, $244 \mathrm{p}$.
Nilles, M.A., Penoyer, P.E., Ludtke, A.S., and Ellsworth, A.C., 2016, The Water-Quality Partnership for national parks-U.S. Geological Survey and National Park Service, 1998-2016: U.S. Geological Survey Fact Sheet 2016-3041, 6 p., accessed December 2017 at https://doi.org/10.3133/ fs 20163041.

Osmundson, B., and Lusk, J.D., 2016, Field assessment of Colorado pikeminnow exposure to mercury within its critical habitat in Colorado, New Mexico and Utah: U.S. Fish and Wildlife Service Report, Project ID FFS\# 6F54 and DEC\# 200860001.1, 53 p.

Parkhurst, D.L., and Appelo, C.A.J., 2013, Description of input and examples for PHREEQC version 3-A computer program for speciation, batch-reaction, onedimensional transport, and inverse geochemical calculations: U.S. Geological Survey Techniques and Methods, book 6, chap. A43, 497 p., accessed September 28, 2018, at https://pubs.usgs.gov/tm/06/a43/.

Parks, J.M., Johs, A., Podar, M., Bridou, R., Hurt, R.A., Jr., Smith, S.D., Tomanicek, S.J., Qian, Y., Brown, S.D., Brandt, C.C., Palumbo, A.V., Smith, J.C., Wall, J.D., Elias, D.A., and Liang, L., 2013, The genetic basis for bacterial mercury methylation: Science, v. 339, no. 6125, p. 1332-1335. [Also available at https://doi.org/10.1126/science.1230667.]

Potter, L., Kidd, D., and Standiford, D., 1975, Mercury levels in Lake Powell-Bioamplification of mercury in man-made desert reservoir: Environmental Science \& Technology, v. 9, no. 1, p. 41-46. [Also available at https://doi.org/10.1021/ es60099a006.]

Potter, L.D., and Pattison, N.B., 1976, Shoreline ecology of Lake Powell, Lake Powell Research Bulletin 29: Los Angeles, Institute of Geophysics and Planetary Physics, University of California, $238 \mathrm{p}$.

Rask, M., Verta, M., Korhonen, M., Salo, S., Forsius, M., Arvola, L., Jones, R.I., and Kiljunen, M., 2010, Does lake thermocline depth affect methyl mercury concentrations in fish?: Biogeochemistry, v. 101, no. 1-3, p. 311-322. [Also available at https://doi.org/10.1007/s10533-010-9487-5.]

Rouleau, C., and Block, M., 1997, Fast and high-yield synthesis of radioactive $\mathrm{CH}_{3}{ }^{203} \mathrm{Hg}(\mathrm{II})$ : Applied Organometallic Chemistry, v. 11, no. 9, p. 751-753. [Also available at https://doi.org/10.1002/(SICI)10990739(199709)11:9<751::AID-AOC631>3.0.CO;2-Z.]

Saraceno, J.F., Shanley, J.B., Downing, B.D., and Pellerin, B.A., 2017, Clearing the waters-Evaluating the need for site-specific field fluorescence corrections based on turbidity measurements: Limnology and Oceanography, v. 15, no. 4, p. 408-416. [Also available at https://doi.org/10.1002/ lom3.10175.] 
Seber, G.A.F., 1982, The estimation of animal abundance and related parameters, 2d ed.: New York, Macmillan, 654 p.

Standiford, D.R., Potter, L.D., and Kidd, D.E., 1973, Mercury in the Lake Powell ecosystem (no. PB-261672; Bull-1): Los Angeles, Lake Powell Research Project, 21 p.

Stanford, J.A., and Ward, J.V., 1991, Limnology of Lake Powell and the chemistry of the Colorado River, in Colorado River Ecology and Dam Management_-Proceedings of a Symposium May 24-25, 1990, Santa Fe, New Mexico: National Academies Press, Washington, D.C., p. 75-101.

Sterner, R.W., Andersen, T., Elser, J.J., Hessen, D.O., Hood, J.M., McCauley, E., and Urabe, J., 2008, Scale-dependent carbon:nitrogen:phosphorus seston stoichiometry in marine and freshwaters: Limnology and Oceanography, v. 53, no. 3, p. 1169-1180. [Also available at https://doi.org/10.4319/ 1o.2008.53.3.1169.]

Sunderland, E.M., Gobas, F.A.P.C., Branfireun, B.A., and Heyes, A., 2006, Environmental controls on the speciation and distribution of mercury in coastal sediments: Marine Chemistry, v. 102, no. 1-2, p. 111-123. [Also available at https://doi.org/10.1016/j.marchem.2005.09.019.]

Tukey, J., 1949, Comparing individual means in the analysis of variance: Biometrics, v. 5, no. 2, p. 99-114.

Turner Designs, Inc., 2018, Effects of turbidity on in vivo chlorophyll: Turner Designs, Inc., Application Note S-0035, accessed December 5, 2017, at https://www.turnerdesigns.com/t2/doc/appnotes/S-0035.pdf.

U.S. Environmental Protection Agency, 2000, Guidance for assessing chemical contaminant data for use in fish advisories, vol. 1, fish sampling and analysis, 3d ed.: U.S. Environmental Protection Agency Report EPA 823-B-00-007, $85 \mathrm{p}$.
Utah Department of Environmental Quality, 2012, Utah fish advisories: Utah Department of Environmental Quality web page, accessed December 6, 2012, at https://deq.utah.gov/ fish-advisories/utah-fish-advisories.

Vernieu, W.S., 2010, Effects of the 2008 high-flow experiment on water quality in Lake Powell and Glen Canyon Dam releases, Utah-Arizona: U.S. Geological Survey Open-File Report 2010-1159, 25 p. [Also available at https://pubs.usgs.gov/of/2010/1159/of2010-1159.pdf.]

Verta, M., Salo, S., Korhonen, M., Porvari, P., Paloheimo, A., and Munthe, J., 2010, Climate induced thermocline change has an effect on the methyl mercury cycle in small boreal lakes: Science of the Total Environment, v. 408, no. 17, p. 3639-3647. [Also available at https://doi.org/10.1016/ j.scitotenv.2010.05.006.]

Welschmeyer, N.A., 1994, Fluorometric analysis of chlorophyll $\mathrm{a}$ in the presence of chlorophyll $\mathrm{b}$ and phaeopigments: Limnology and Oceanography, v. 39, no. 8, p. 1985-1992. [Also available at https://doi.org/10.4319/ 10.1994.39.8.1985.]

Wilde, F.D., Radtke, D.B., Gibs, J., and Iwatsubo, R.T., eds., 2009, Processing of water samples (ver. 2.2): U.S. Geological Survey Techniques of Water-Resources Investigations, book 9, chap. A5, accessed January 26, 2018, at https://pubs.water.usgs.gov/twri9A5/. 
Appendixes 


\section{Appendix 1. Abbreviations and Definitions for Appendixes 2-6}

Table 1.1. Abbreviations and definitions for appendixes 2-6.

\begin{tabular}{|c|c|}
\hline Abbreviation & Definition \\
\hline \multicolumn{2}{|r|}{ Y parameters } \\
\hline $\mathrm{T}$ & Temperature \\
\hline $\mathrm{SC}$ & Specific conductance \\
\hline $\mathrm{DO}$ & Dissolved oxygen \\
\hline fDOM & Fluorescent dissolved organic matter \\
\hline TURB & Turbidity \\
\hline Chl.a & Chlorophyll $a$ \\
\hline NPDOC & Nonpurgeable dissolved organic carbon \\
\hline $\mathrm{C}$ & Carbon \\
\hline NPOC & Nonpurgeable organic carbon \\
\hline DIC & Dissolved inorganic carbon \\
\hline TSS & Total suspended solids \\
\hline $\mathrm{NH}_{4}$ (Menlo Park) & Ammonia \\
\hline $\mathrm{PO}_{4}$ & Phosphate \\
\hline $\mathrm{NO}_{2}$ & Nitrite \\
\hline $\mathrm{NO}_{3}$ (Denver) & Nitrate \\
\hline $\mathrm{SO}_{4}$ & Sulfate \\
\hline $\mathrm{SO}_{4} / \mathrm{Cl}$ & Sulfate to chloride ratio \\
\hline $\mathrm{Ca}$ & Calcium \\
\hline ALK & Total alkalinity \\
\hline PHREEQC & $\begin{array}{l}\text { A computer program developed by the U.S. Geological Survey designed to perform a } \\
\text { wide variety of aqueous geochemical calculations (Parkhurst and Appelo, 2013). }\end{array}$ \\
\hline DOC & Dissolved organic carbon \\
\hline SUVA & Specific ultraviolet absorption \\
\hline f.MeHg & Filter-passing methylmercury \\
\hline f.THg & Filter-passing total mercury \\
\hline p.MeHg.vol & Volumetric particulate methylmercury \\
\hline p.THg.vol & Volumetric particulate total mercury \\
\hline p.MeHg.mass & Gravimetric particulate methylmercury \\
\hline p.THg.mass & Gravimetric particulate total mercury \\
\hline $\mathrm{Kd}[\mathrm{MeHg}]$ & Aqueous particulate partitioning coefficient for methylmercury \\
\hline $\mathrm{Kd}[\mathrm{THg}]$ & Aqueous particulate partitioning coefficient for total mercury \\
\hline$\%$ f.MeHg & Percent of filtered methylmercury (monomethylmercury) \\
\hline$\%$ p.MeHg & Percent of particulate methylmercury \\
\hline uf.MeHg & Unfiltered methylmercury \\
\hline uf.THg & Unfiltered total mercury \\
\hline 16S rRNA & Ribosomal ribonucleic acid, small subunit 16 \\
\hline$\delta^{34} \mathrm{~S}$ VCDT & $\begin{array}{l}\text { Delta sulfur-34 value relative to the Vienna-Canyon Diablo Troilite reference } \\
\text { (standard for sulfur isotope measurements) }\end{array}$ \\
\hline POC & Particulate organic carbon \\
\hline
\end{tabular}


Table 1.1. Abbreviations and definitions for appendixes $2-6$. - Continued

\begin{tabular}{|c|c|}
\hline Abbreviation & Definition \\
\hline \multicolumn{2}{|r|}{ Y parameters-Continued } \\
\hline PN & Particulate nitrogen \\
\hline$\delta^{13} \mathrm{C}-\mathrm{POC}$ & Delta carbon-13 value, particulate organic carbon \\
\hline$\delta^{15} \mathrm{~N}-\mathrm{PN}$ & Delta nitrogen-15 value, particulate nitrogen \\
\hline $\mathrm{THg}$ & Total mercury \\
\hline $\mathrm{RHg}$ & Sediment reactive mercury \\
\hline$\% . \mathrm{RHg}$ & Particulate (water column) reactive mercury \\
\hline $\mathrm{MeHg}$ & Methylmercury \\
\hline$\% . \mathrm{MeHg}$ & Methylmercury as a percentage of total mercury \\
\hline $\mathrm{THg} / \mathrm{LOI}$ & Total mercury normalized to sediment organic content \\
\hline $\mathrm{RHg} / \mathrm{LOI}$ & Reactive mercury normalized to sediment organic content \\
\hline $\mathrm{MeHg} / \mathrm{LOI}$ & Methylmercury normalized to sediment organic content \\
\hline $\mathrm{k}_{\text {meth }}$ & Mercury-methylation rate constant \\
\hline MPP & Methylmercury production potential \\
\hline MPP.area & Methylmercury production potential based on reactive inorganic mercury \\
\hline $\mathrm{k}_{\mathrm{deg}}$ & Methylmercury degradation rate constant \\
\hline MDP & Methylmercury degradation potential \\
\hline MDP.area & Methylmercury degradation potential based on in-situ methylmercury average \\
\hline NET.chng.MeHg.1d & Change in ambient methylmercury concentration in 1-day MDP incubations \\
\hline NET.chng.MeHg.7d & Change in ambient methylmercury concentration in 7-day MDP incubations \\
\hline $\mathrm{E}_{\mathrm{h}}$ & Temperature corrected redox potential \\
\hline DW & Dry weight \\
\hline $\mathrm{BD}$ & Bulk density \\
\hline POR & Porosity \\
\hline GS & Grain size \\
\hline TRS & Total reduced sulfur \\
\hline $\mathrm{Fe}(\mathrm{II})$ & Acid extractable ferrous iron \\
\hline $\mathrm{Fe}(\mathrm{III})_{\mathrm{a}}$ & Amorphous (poorly crystalline) ferric iron \\
\hline $\mathrm{Fe}(\mathrm{III})_{\mathrm{c}}$ & Crystalline ferric iron \\
\hline $\mathrm{Fe}_{\mathrm{T}}$ & Total measured iron $\left(\mathrm{Fe}[\mathrm{II}]+\mathrm{Fe}[\mathrm{III}]_{\mathrm{a}}+\mathrm{Fe}[\mathrm{III}]_{\mathrm{c}}\right)$ \\
\hline$\% . \mathrm{Fe}(\mathrm{II})$ & Percent of acid extractable ferrous iron \\
\hline plank.vol & Plankton biomass, volumetric (individual size fractions) \\
\hline plnk.MeHg.mass & Plankton methylmercury concentration, gravimetric (individual size fractions) \\
\hline plnk.MeHg.vol & Plankton methylmercury concentration, volumetric (individual size fractions) \\
\hline plnk.THg.mass & Plankton total mercury concentration, gravimetric (individual size fractions) \\
\hline plnk.THg.vol & Plankton total mercury concentration, volumetric (individual size fractions) \\
\hline plnk.\%MeHg & Plankton percent methylmercury (individual size fractions) \\
\hline bulk.vol & Bulk plankton biomass, volumetric \\
\hline bulk/TSS.mass & Bulk plankton biomass (by weight) per total suspended sediment mass (by weight) \\
\hline bulk.\%.MeHg & Bulk plankton percent methylmercury \\
\hline bulk.MeHg.mass & Bulk plankton methylmercury concentration, gravimetric \\
\hline bulk.MeHg.vol & Bulk plankton methylmercury concentration, volumetric \\
\hline
\end{tabular}

bulk.MeHg.vol

Bulk plankton methylmercury concentration, volumetric 
Table 1.1. Abbreviations and definitions for appendixes 2-6.-Continued

\begin{tabular}{|c|c|}
\hline Abbreviation & Definition \\
\hline \multicolumn{2}{|r|}{ Y parameters-Continued } \\
\hline bulk.THg.mass & Bulk plankton total mercury concentration, gravimetric \\
\hline bulk.THg.vol & Bulk plankton total mercury concentration, volumetric \\
\hline THg at $420 \mathrm{~mm}$ & Total mercury at 420 millimeters \\
\hline$\delta^{199} \mathrm{Hg}$ & Delta mercury-199 value \\
\hline$\delta^{200} \mathrm{Hg}$ & Delta mercury-200 value \\
\hline$\delta^{201} \mathrm{Hg}$ & Delta mercury-201 value \\
\hline$\delta^{202} \mathrm{Hg}$ & Delta mercury-202 value \\
\hline$\Delta^{199} \mathrm{Hg}$ & Capital delta mercury-199 value \\
\hline$\Delta^{200} \mathrm{Hg}$ & Capital delta mercury-200 value \\
\hline$\Delta^{201} \mathrm{Hg}$ & Capital delta mercury-201 value \\
\hline \multicolumn{2}{|r|}{ Units } \\
\hline${ }^{\circ} \mathrm{C}$ & Degree Celsius \\
\hline$\mu \mathrm{S} / \mathrm{cm}$ & Microsiemens per centimeter \\
\hline $\mathrm{mg} / \mathrm{L}$ & Milligram per liter \\
\hline RFU & Relative fluorescence unit \\
\hline NTU & Nephelometric turbidity unit \\
\hline$\mu \mathrm{g} / \mathrm{L}$ & Microgram per liter \\
\hline $\mathrm{mg} \mathrm{C} / \mathrm{L}$ & Milligram carbon per liter \\
\hline$\%$ & Per mille \\
\hline $\mathrm{meq} / \mathrm{L}$ & Milliequivalent per liter \\
\hline $\mathrm{L} / \mathrm{mg} \mathrm{C} \mathrm{m}$ & Liter per milligram carbon per meter \\
\hline $\mathrm{ng} / \mathrm{L}$ & Nanogram per liter \\
\hline $\mathrm{ng} / \mathrm{g}$ & Nanogram per gram \\
\hline $\mathrm{L} / \mathrm{kg}$ & Liter per kilogram \\
\hline$\%$ & Percent \\
\hline temp/L & 16S rRNA gene template per liter \\
\hline wt. & Weight \\
\hline $1 / \mathrm{d}$ & Per day \\
\hline $\mathrm{pg} / \mathrm{g} / \mathrm{d}$ & Picogram per gram per day \\
\hline $\mathrm{ng} / \mathrm{m}^{2} / \mathrm{d}$ & Nanogram per square meter per day \\
\hline $\mathrm{mV}$ & Millivolt \\
\hline $\mathrm{g} / \mathrm{cm}^{3}$ & Gram per cubic centimeter \\
\hline sed. & Sediment \\
\hline $\mathrm{ml} \mathrm{PW} / \mathrm{cm}^{3}$ wet sed. & Milliliter of pore water per cubic centimeter of wet sediment \\
\hline$\mu \mathrm{mol} / \mathrm{g}$ & Micromole per gram dry weight \\
\hline $\mathrm{mg} / \mathrm{g}$ & Milligram per gram \\
\hline temp/g & 16S rRNA gene template per gram \\
\hline $\mathrm{pg} / \mathrm{L}$ & Picogram per liter \\
\hline
\end{tabular}




\section{Appendix 2. Arithmetic and Modeled Least Square Means for Surface Water Parameters}

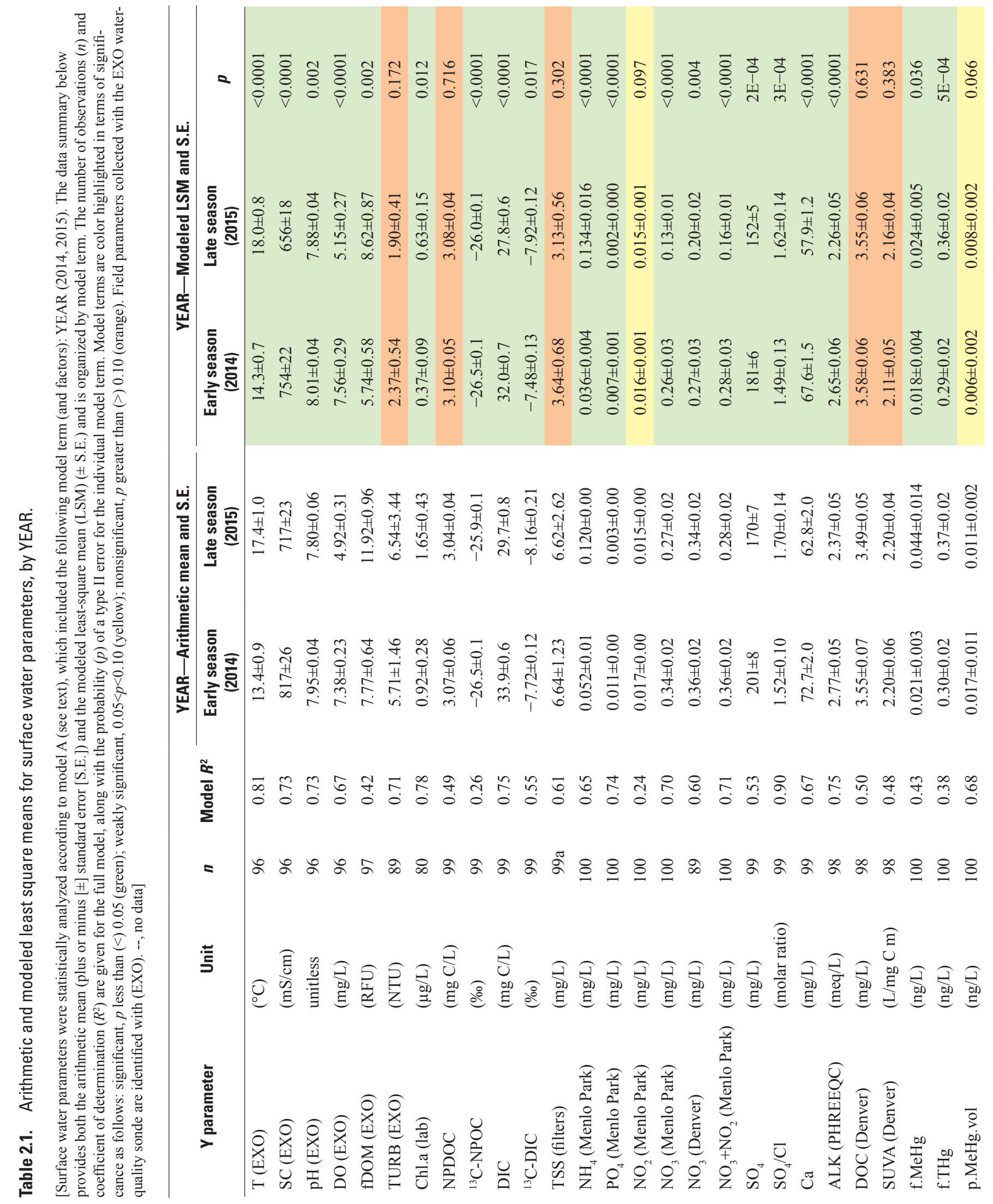




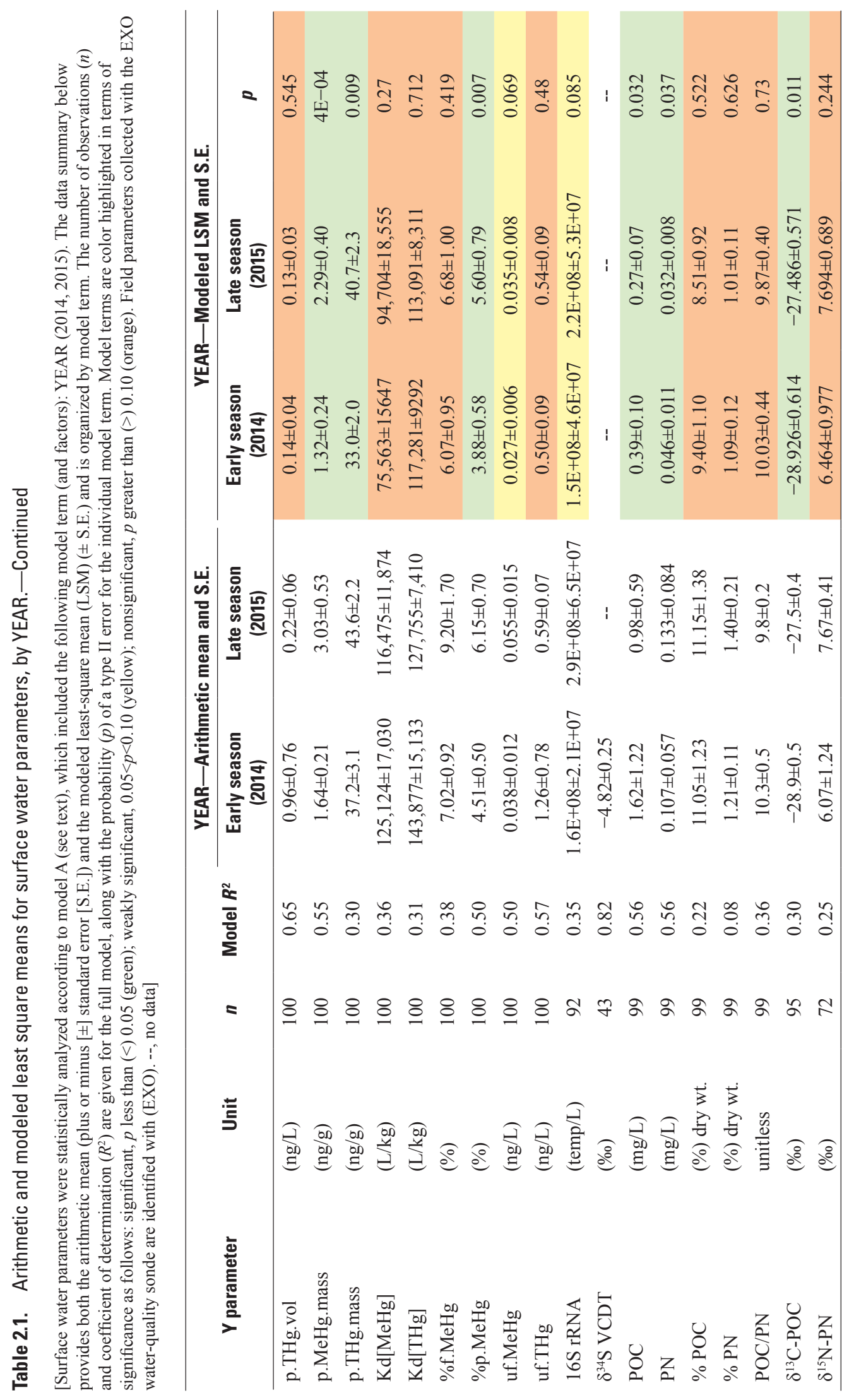




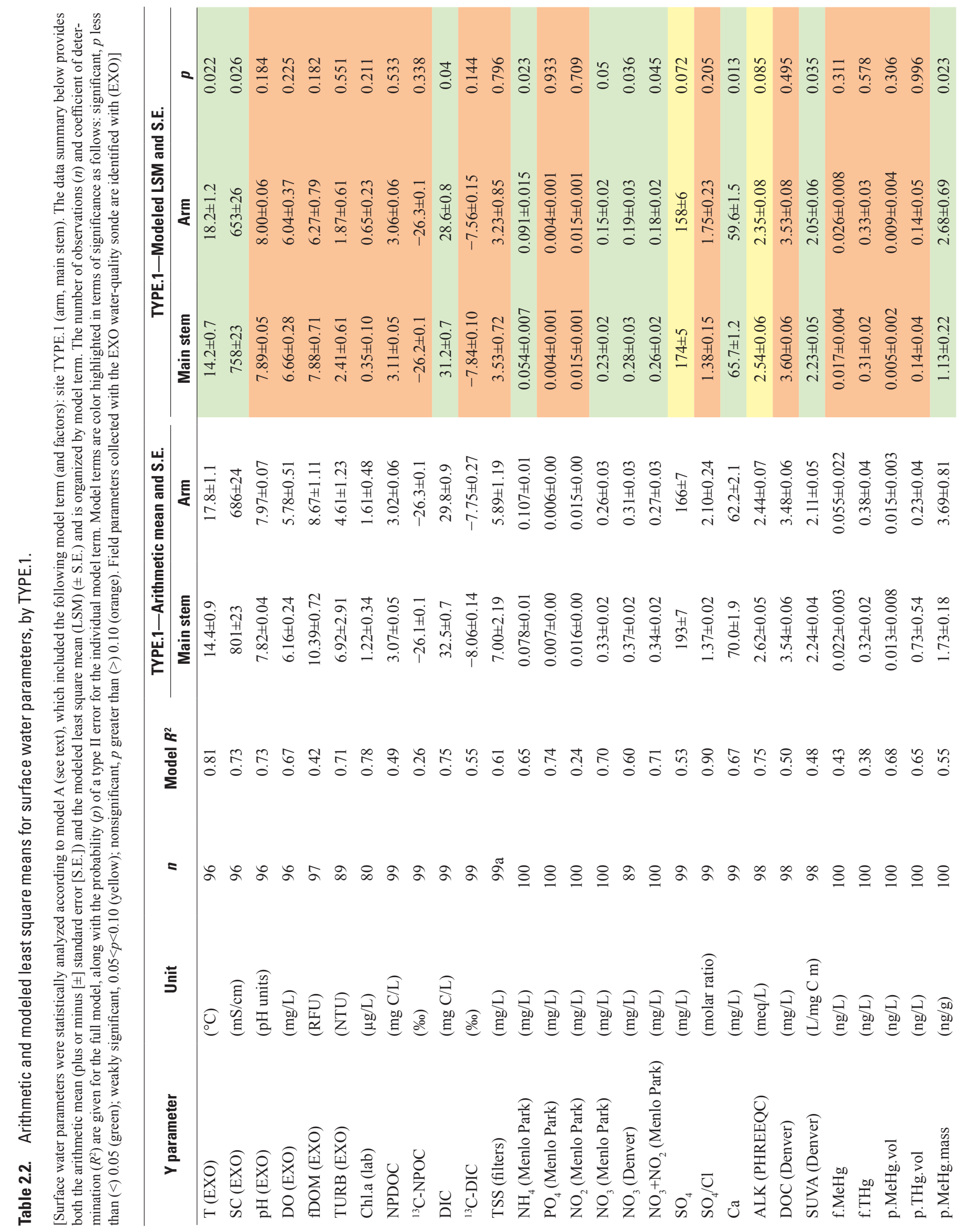



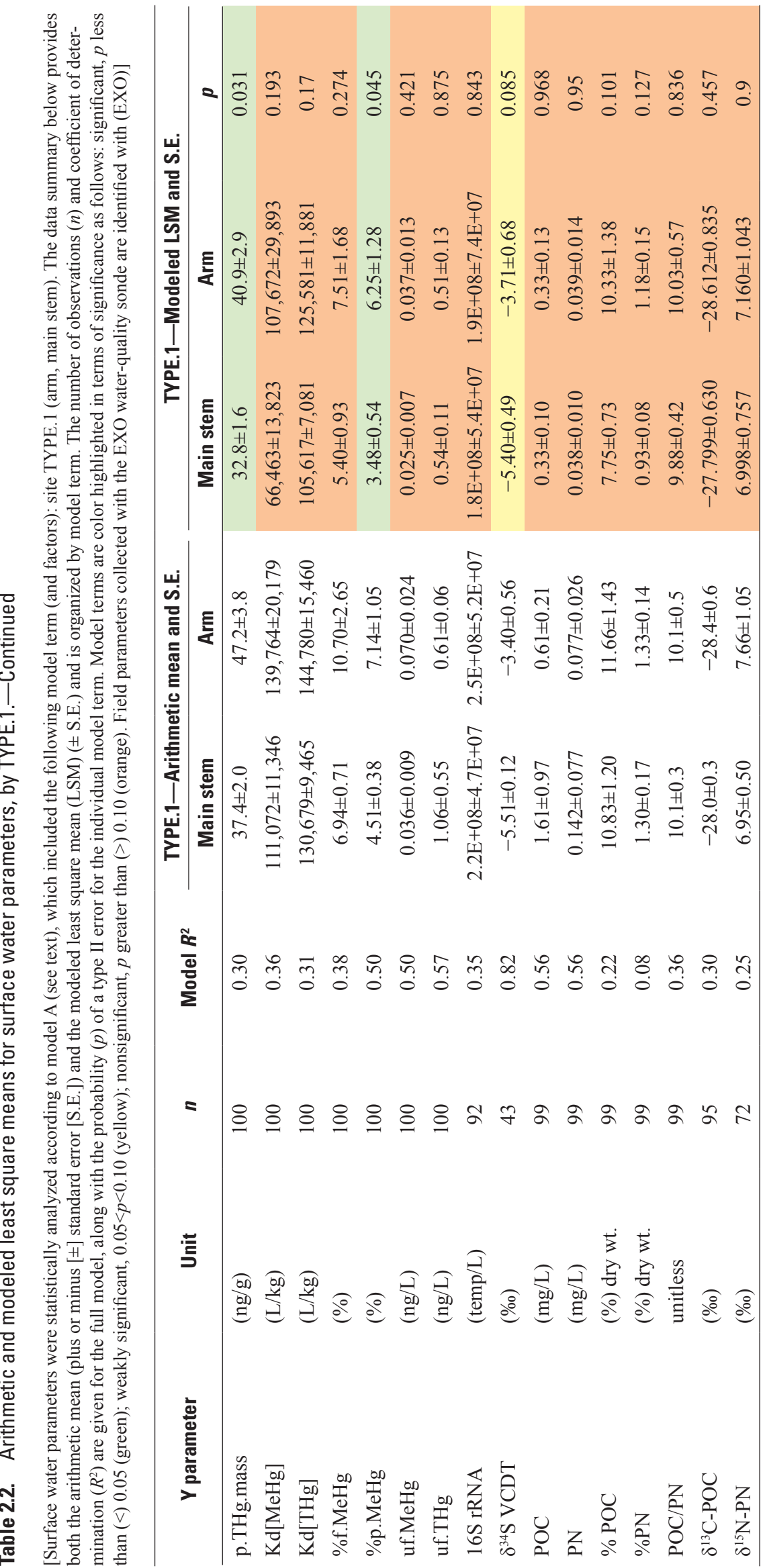


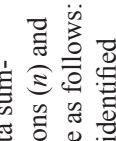

劳 卷

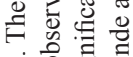

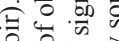

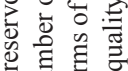

可言

它导势

ثี

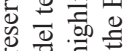

它吉

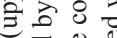

त 马ू⿱乛龰

竞

然可

禺语

茄

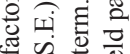

进要江

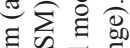

렬

항

ㄴ.

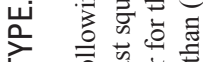

ठ

क

屯 है है

政

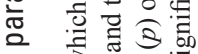

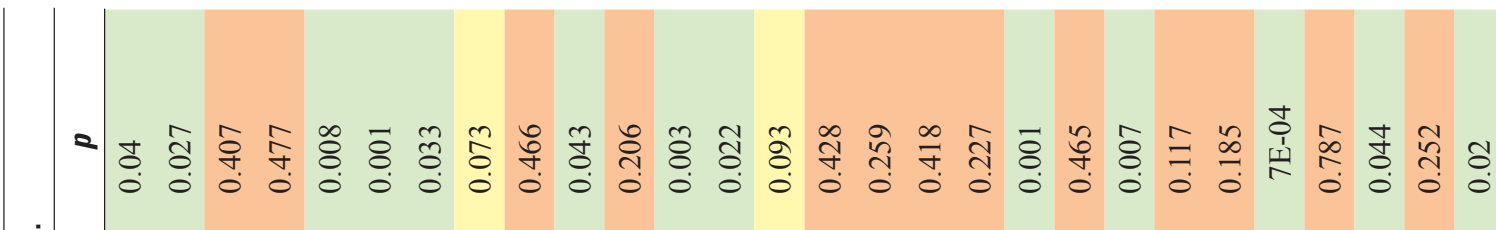

نே.

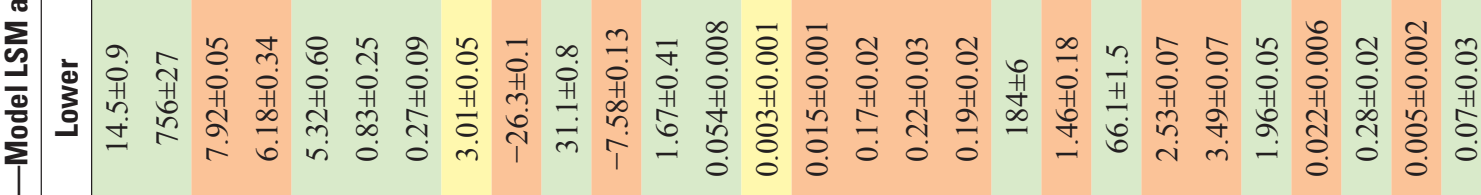

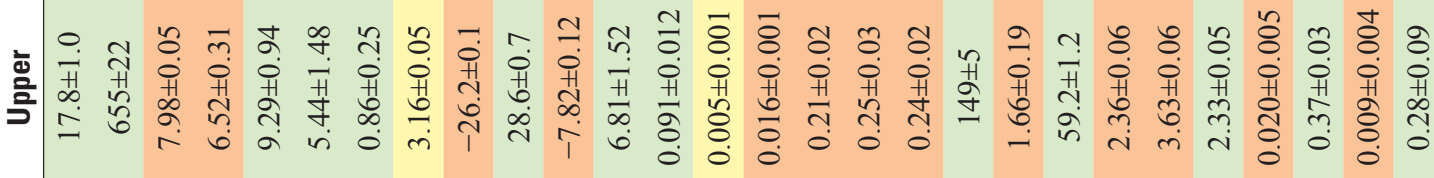

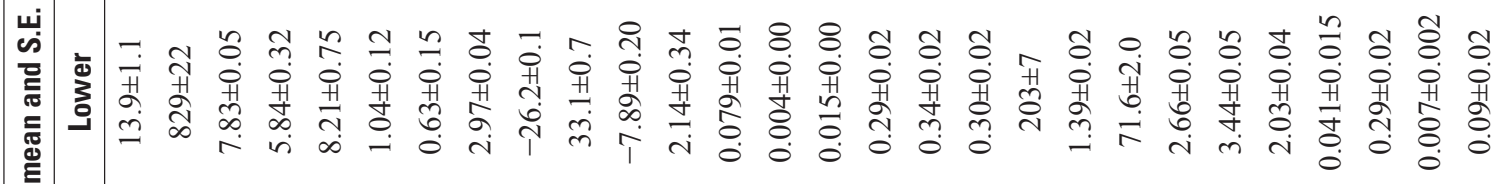

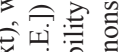

范望语

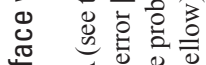

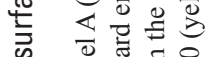

뜸 믐은

은 톤

을

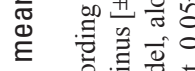

ఏँ

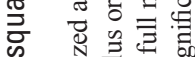

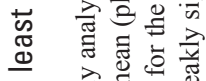

츙

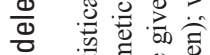

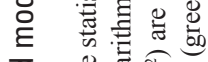

당

.0

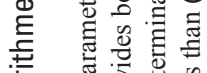

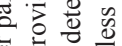

भ.

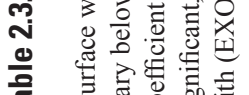

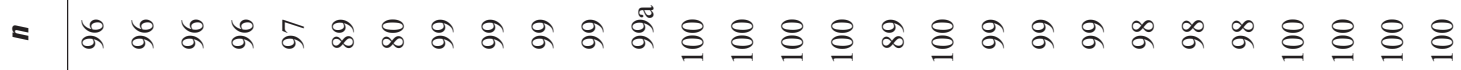

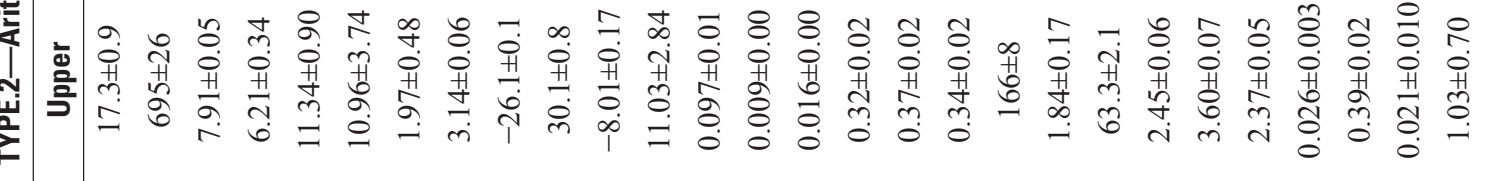

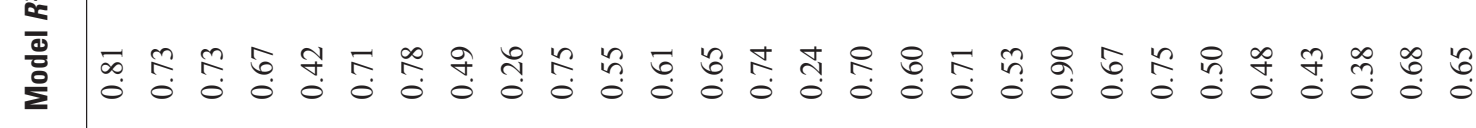

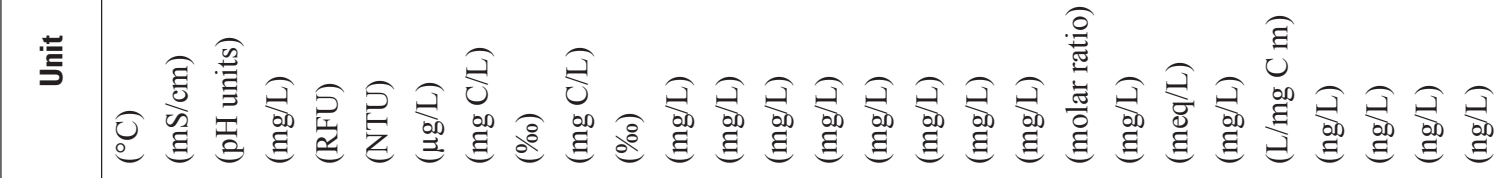

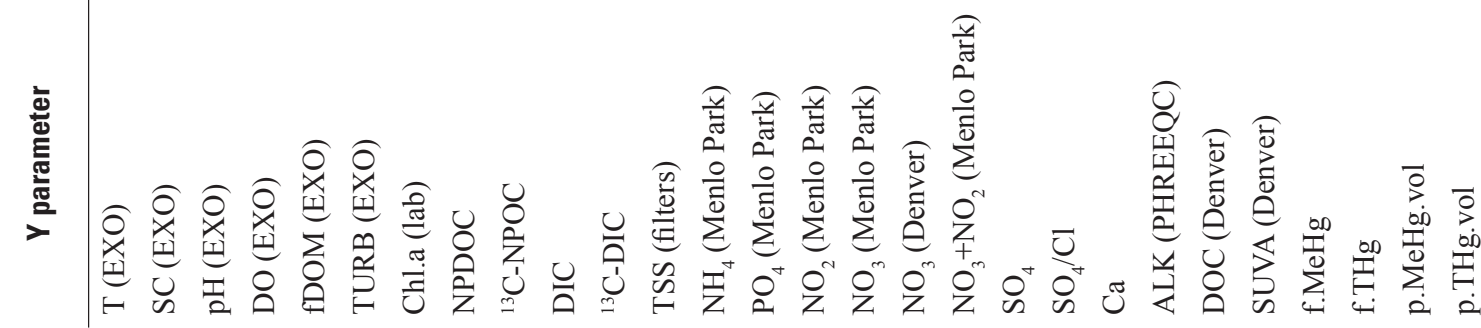




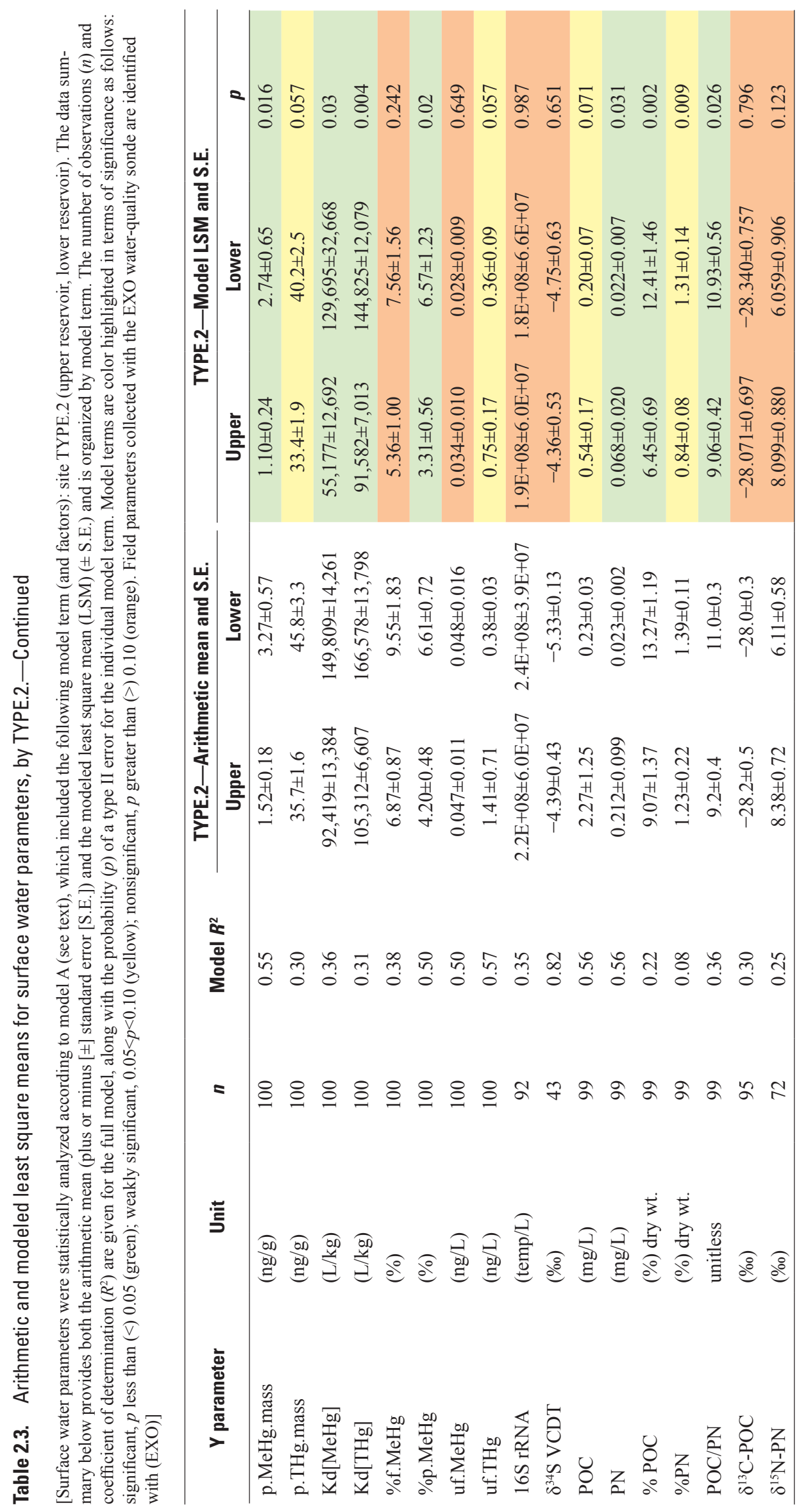




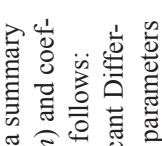

焉 $\widehat{E}$ 记

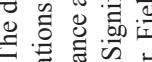

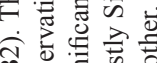

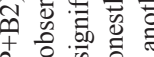

不

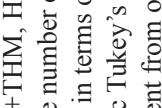

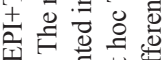

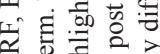

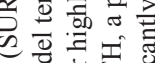

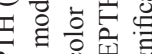

武

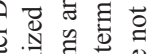

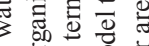

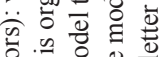

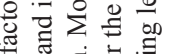

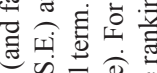

进害些

可

( $)$ 일

芒

岩

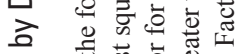

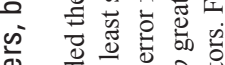

迹

을

를 의

3

现

计

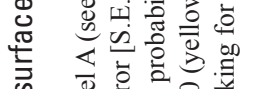

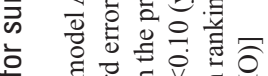

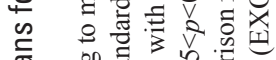

要 卷

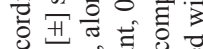

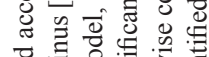

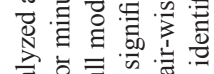

줄

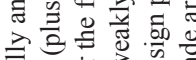

不

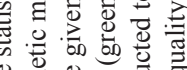

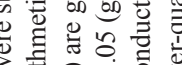

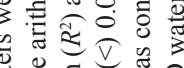

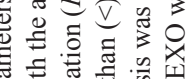

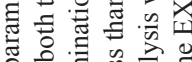

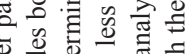

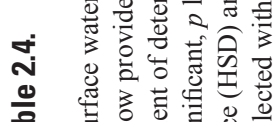

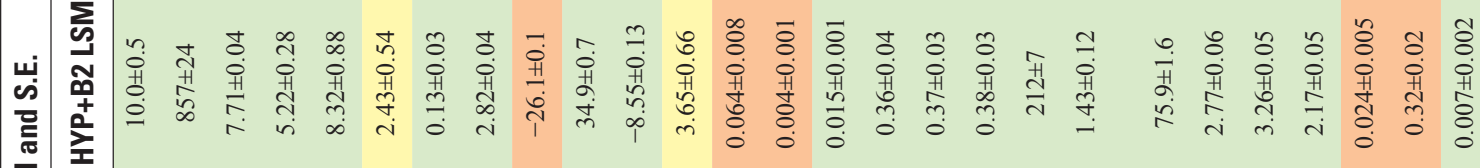

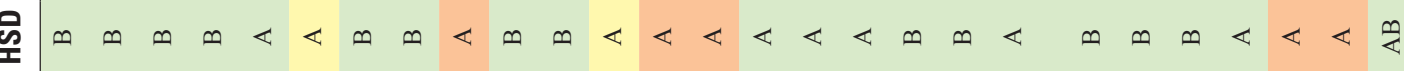

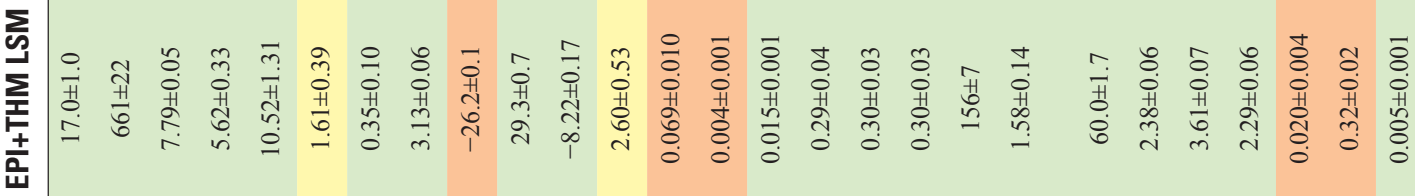

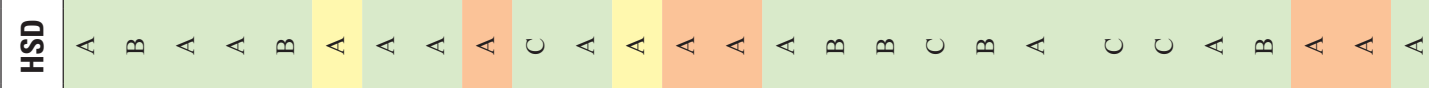

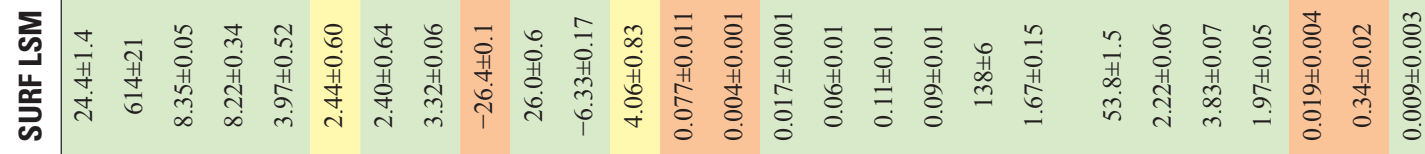

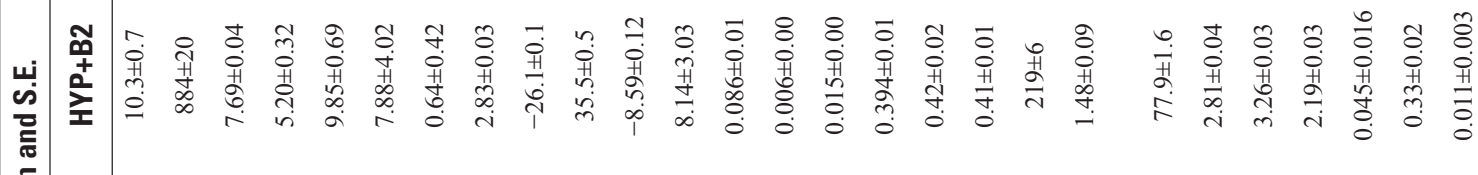

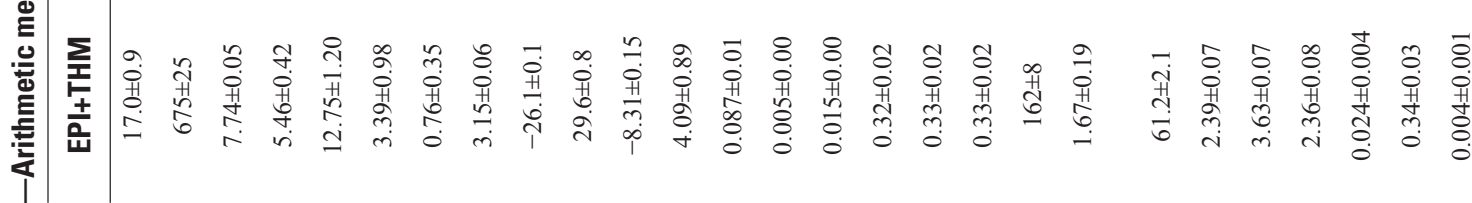

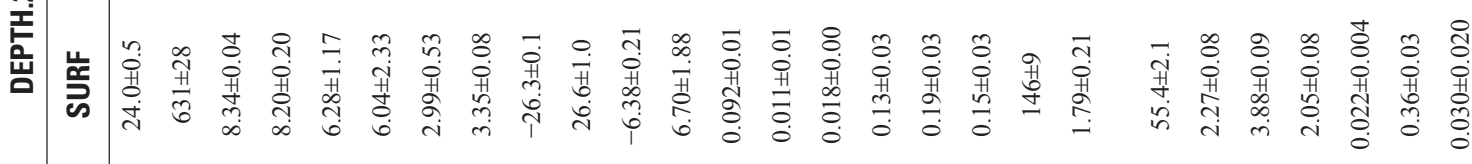

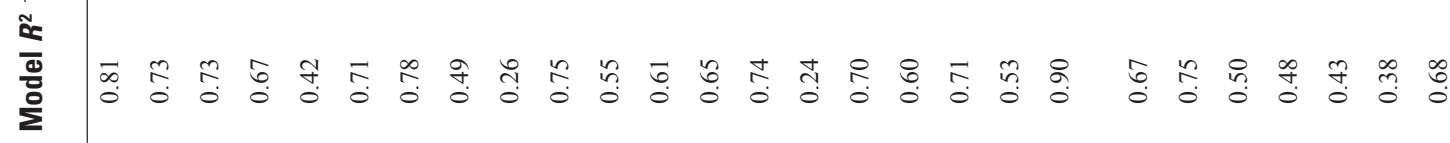

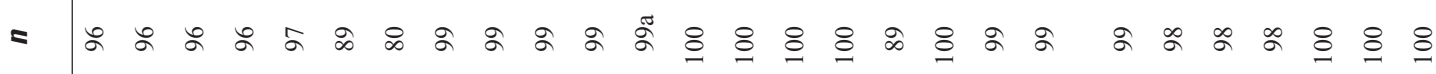

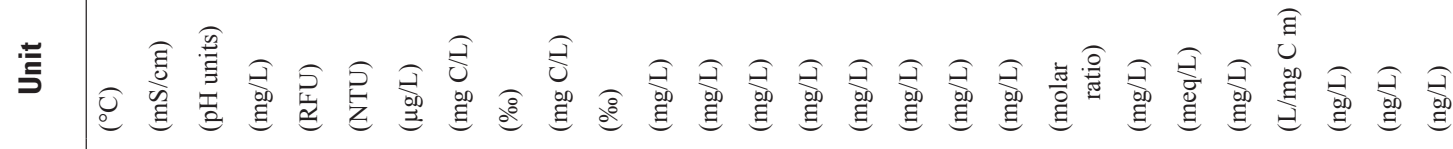

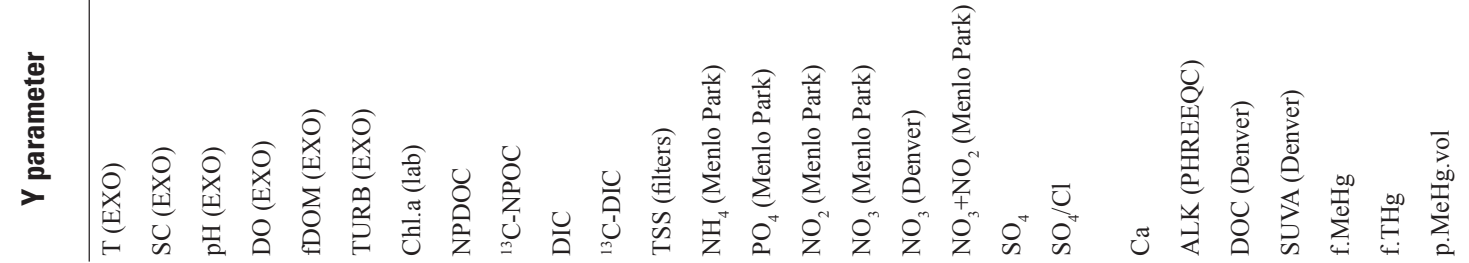




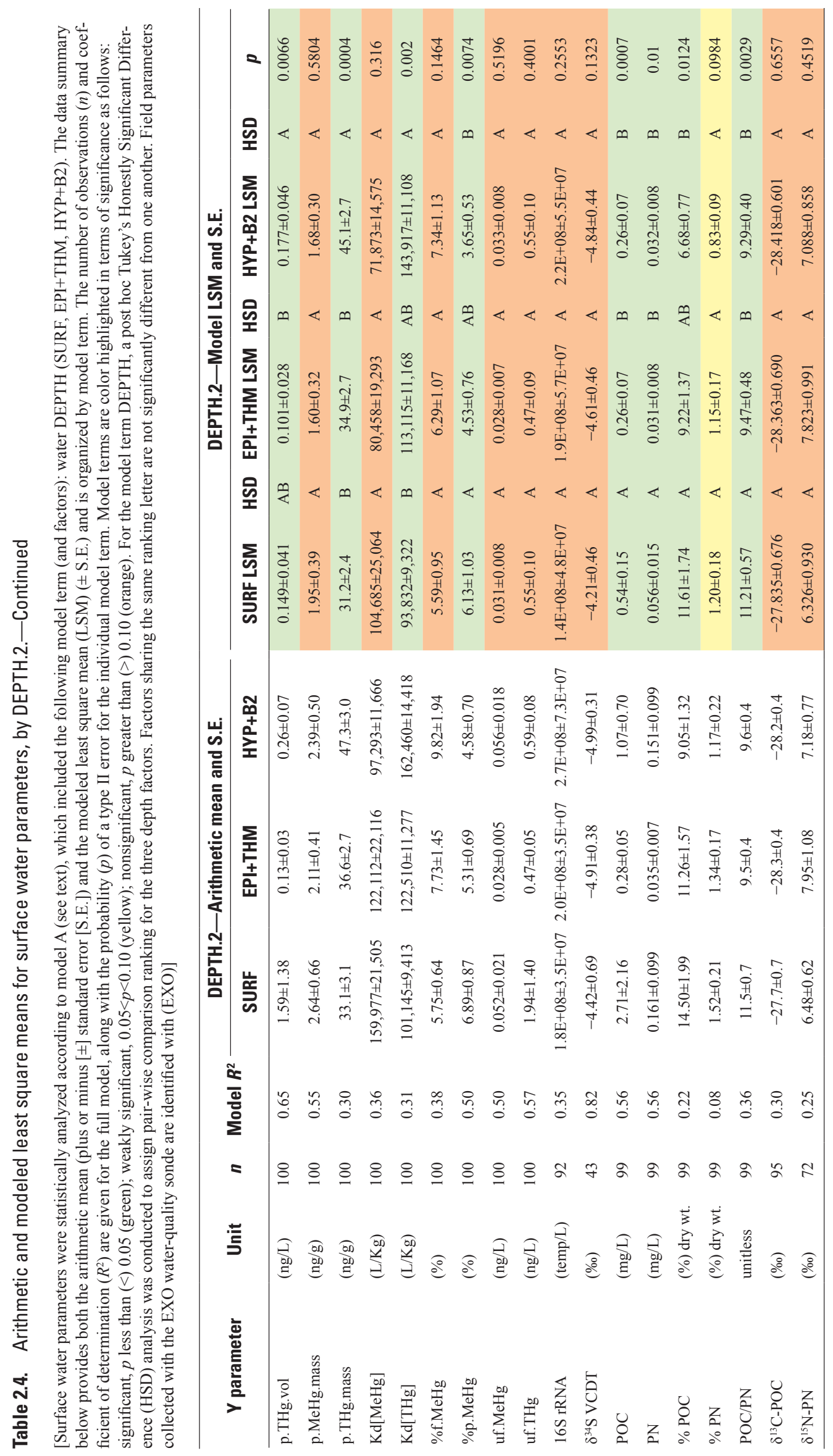




\section{Appendix 3. Arithmetic and Modeled Least Square Means for Surface Sediment Parameters, by YEAR and TYPE.1}

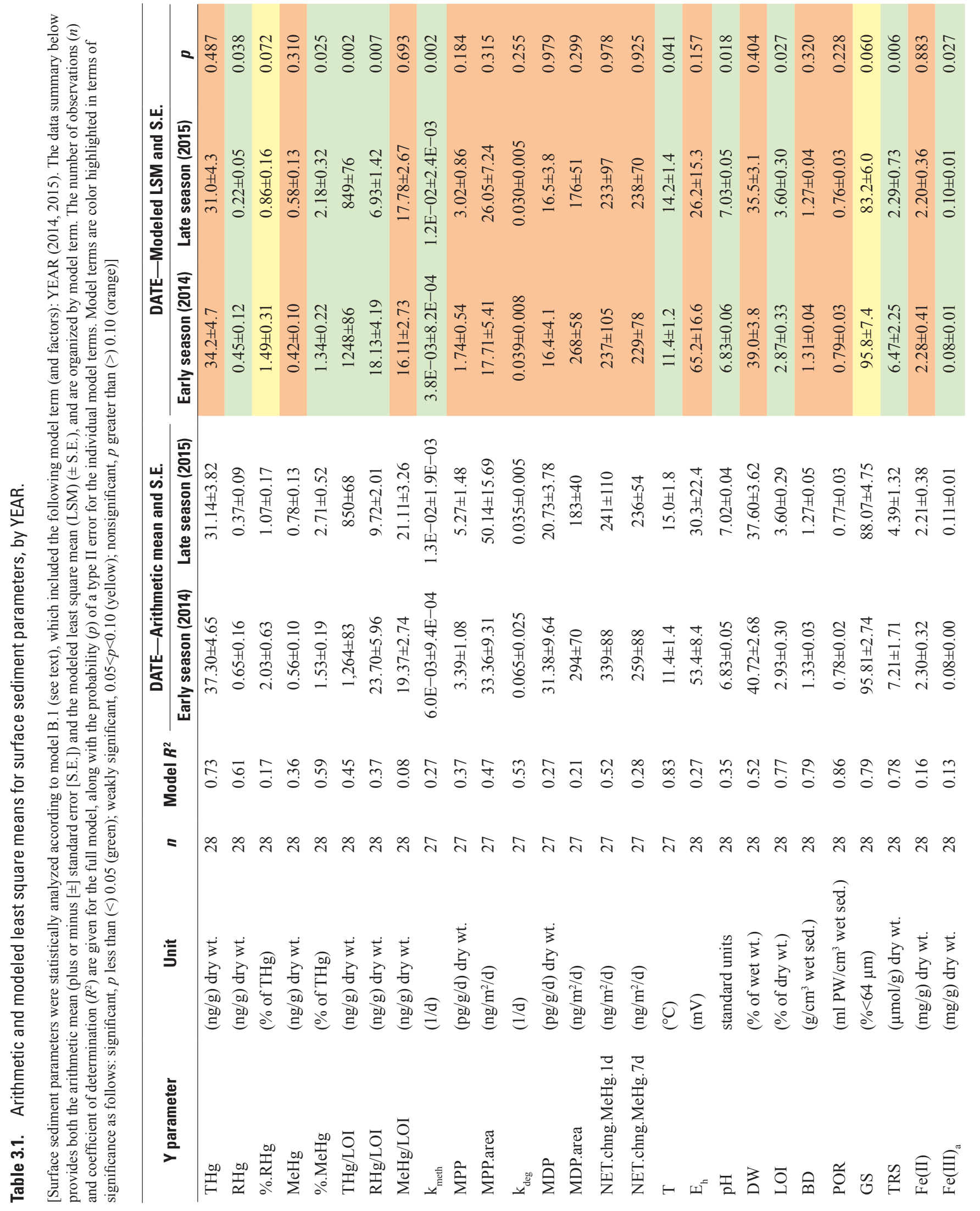




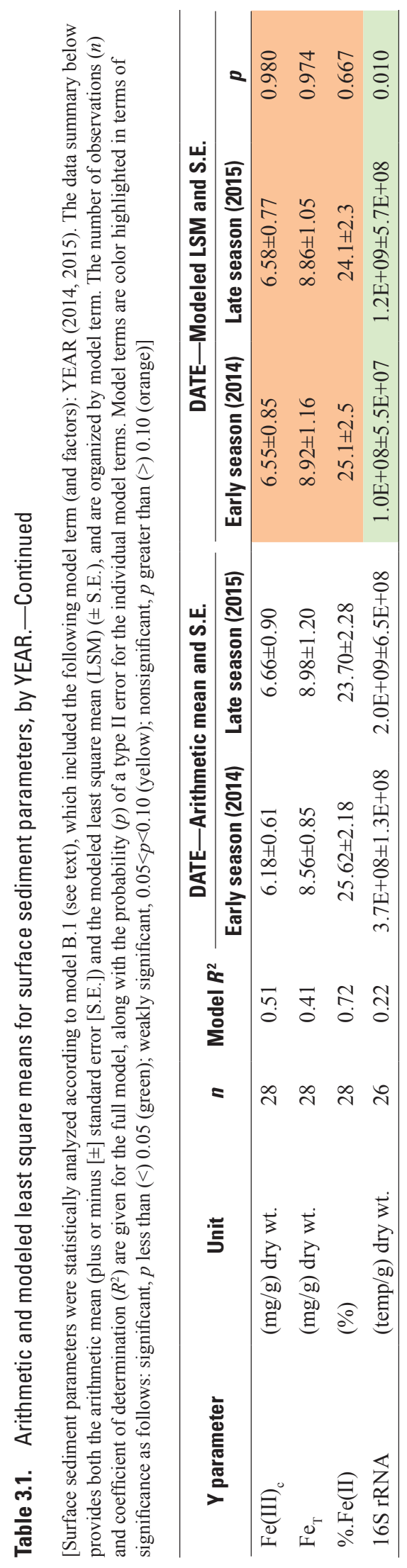




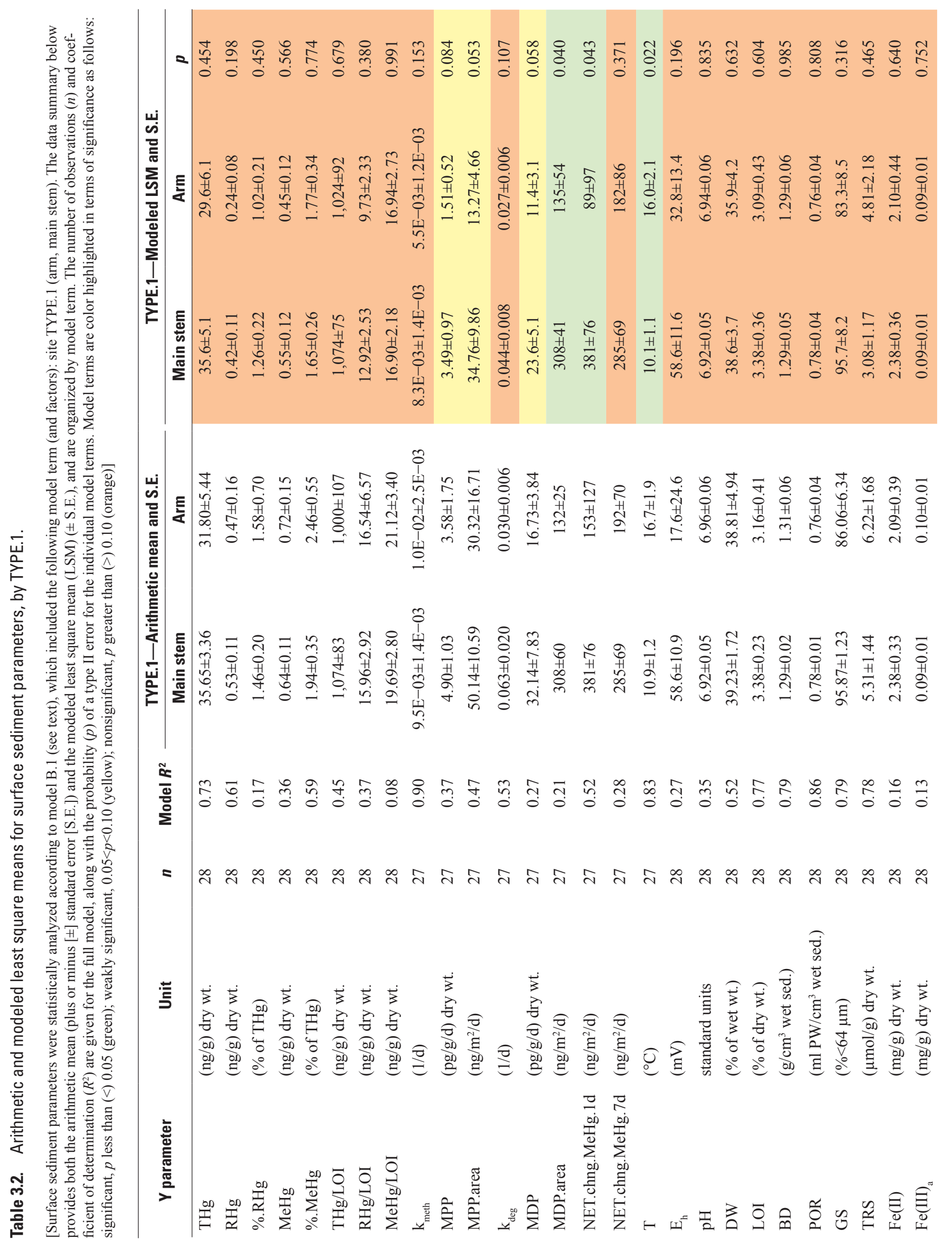




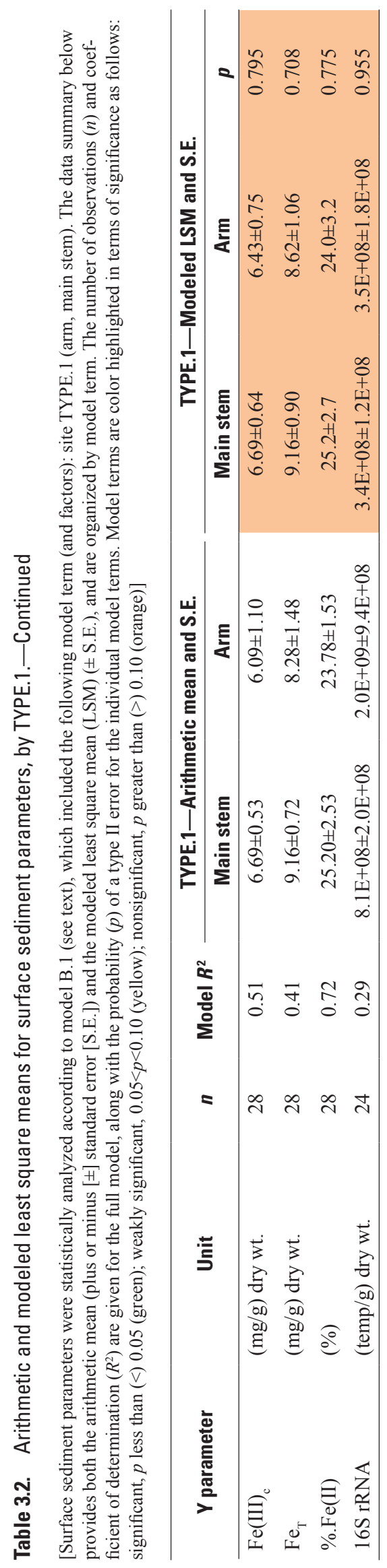




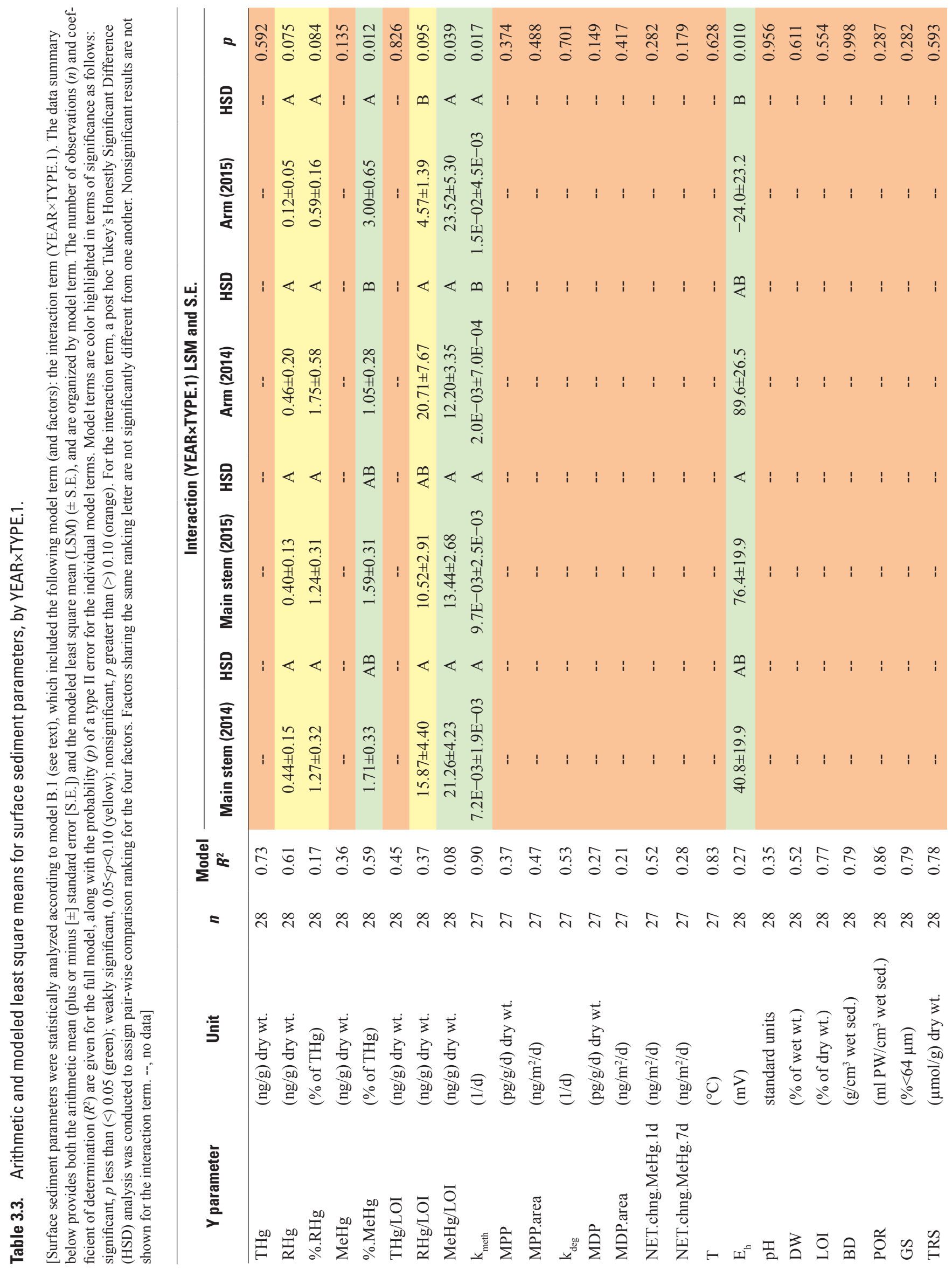




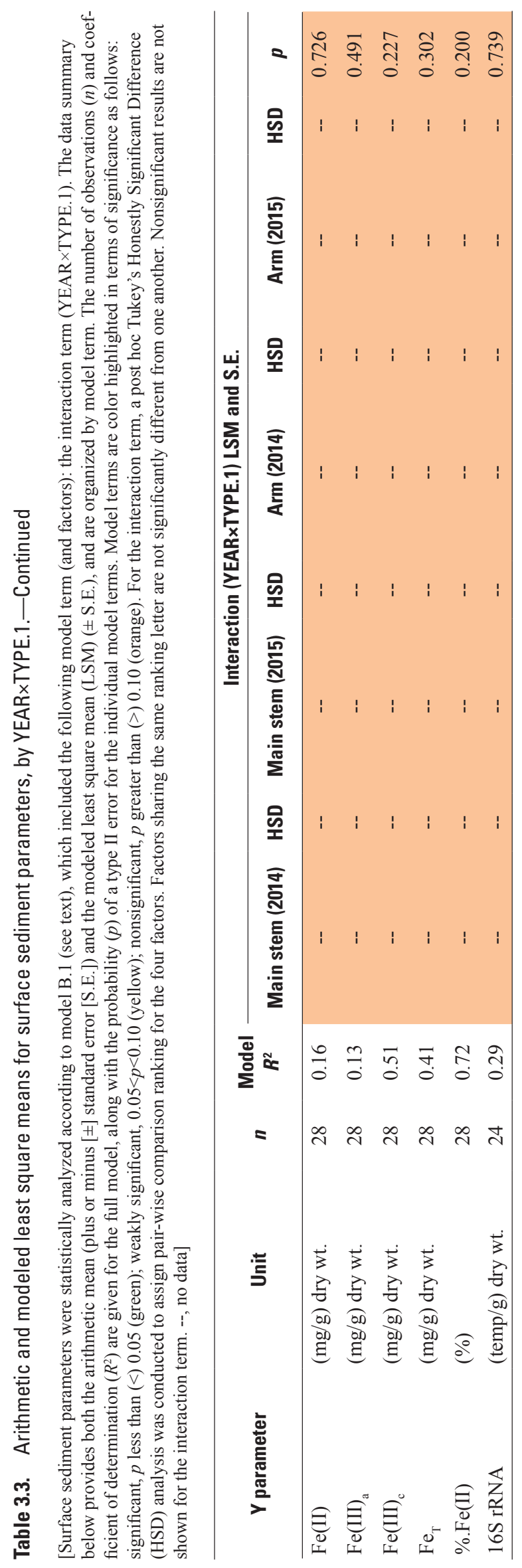




\section{Appendix 4. Arithmetic and Modeled Least Square Means for Surface Sediment Parameters, by YEAR and TYPE.2}
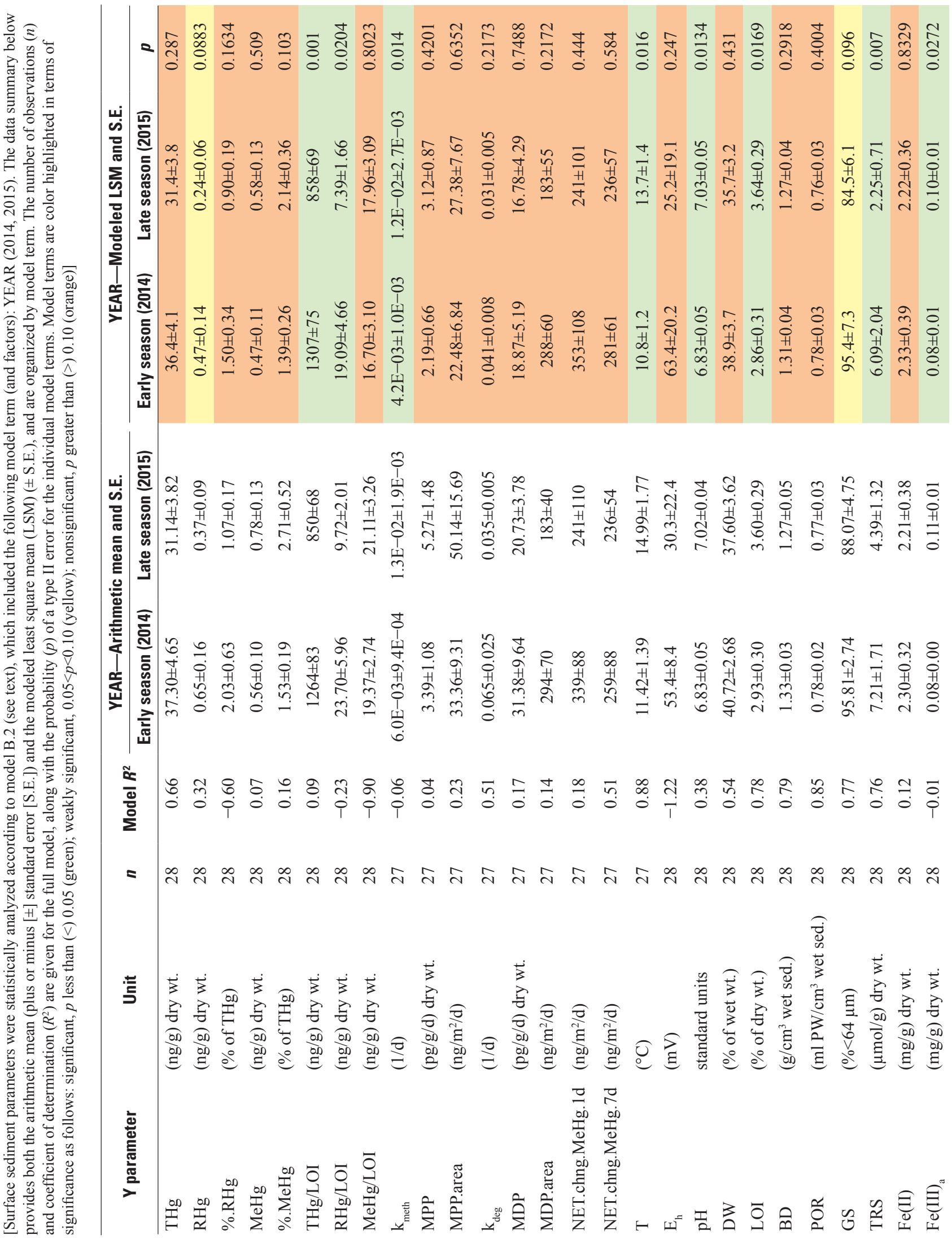


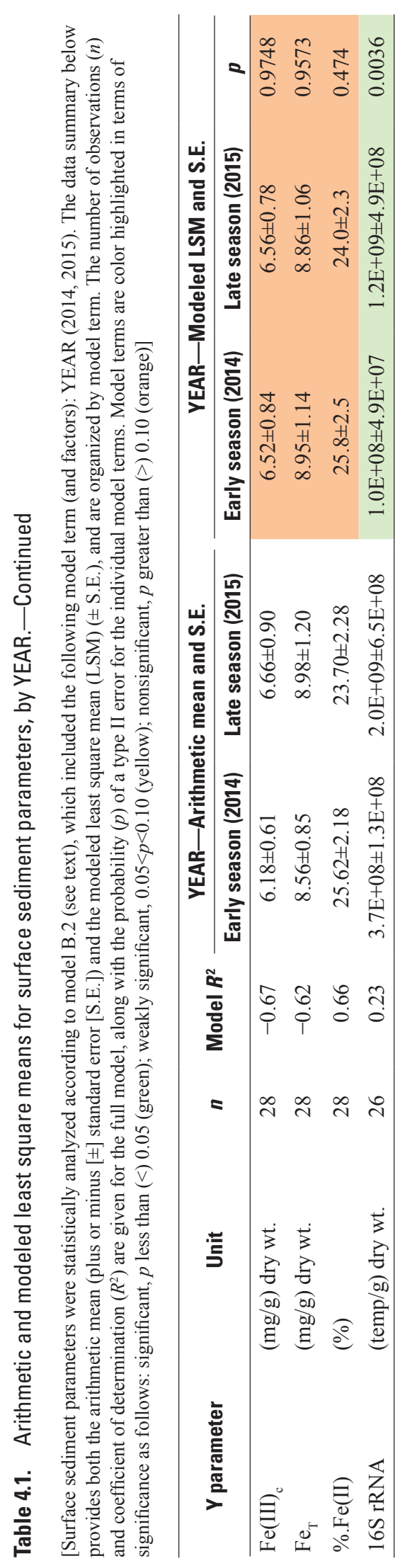




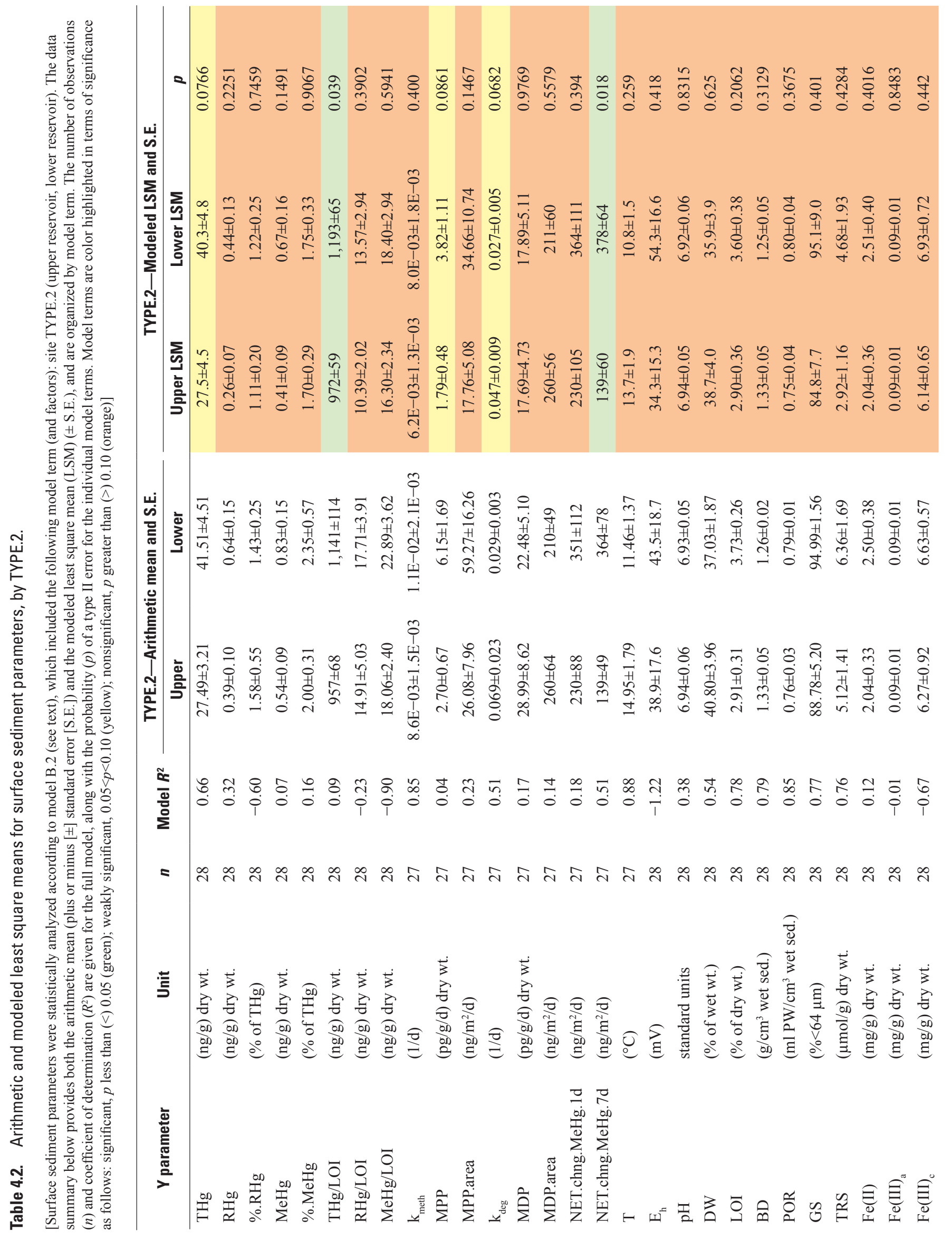




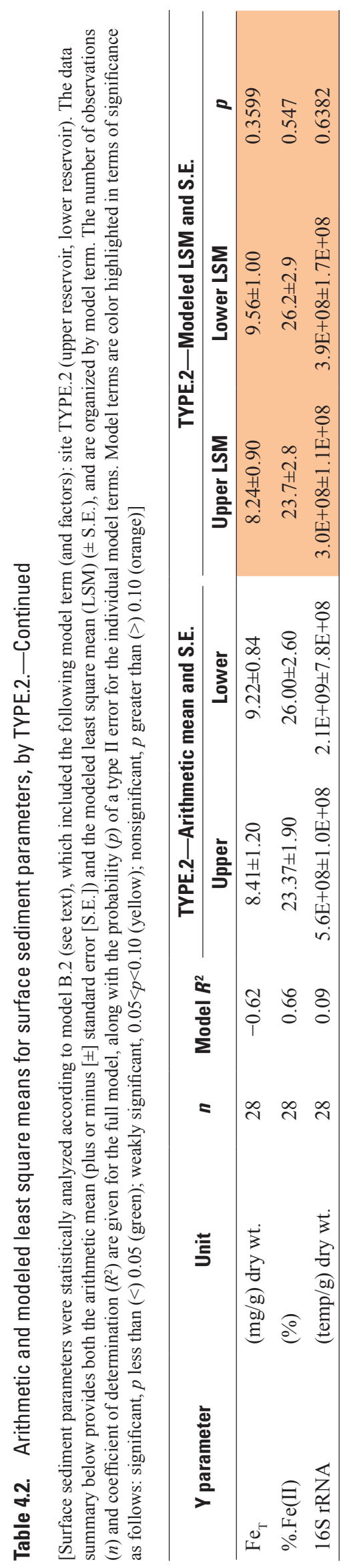




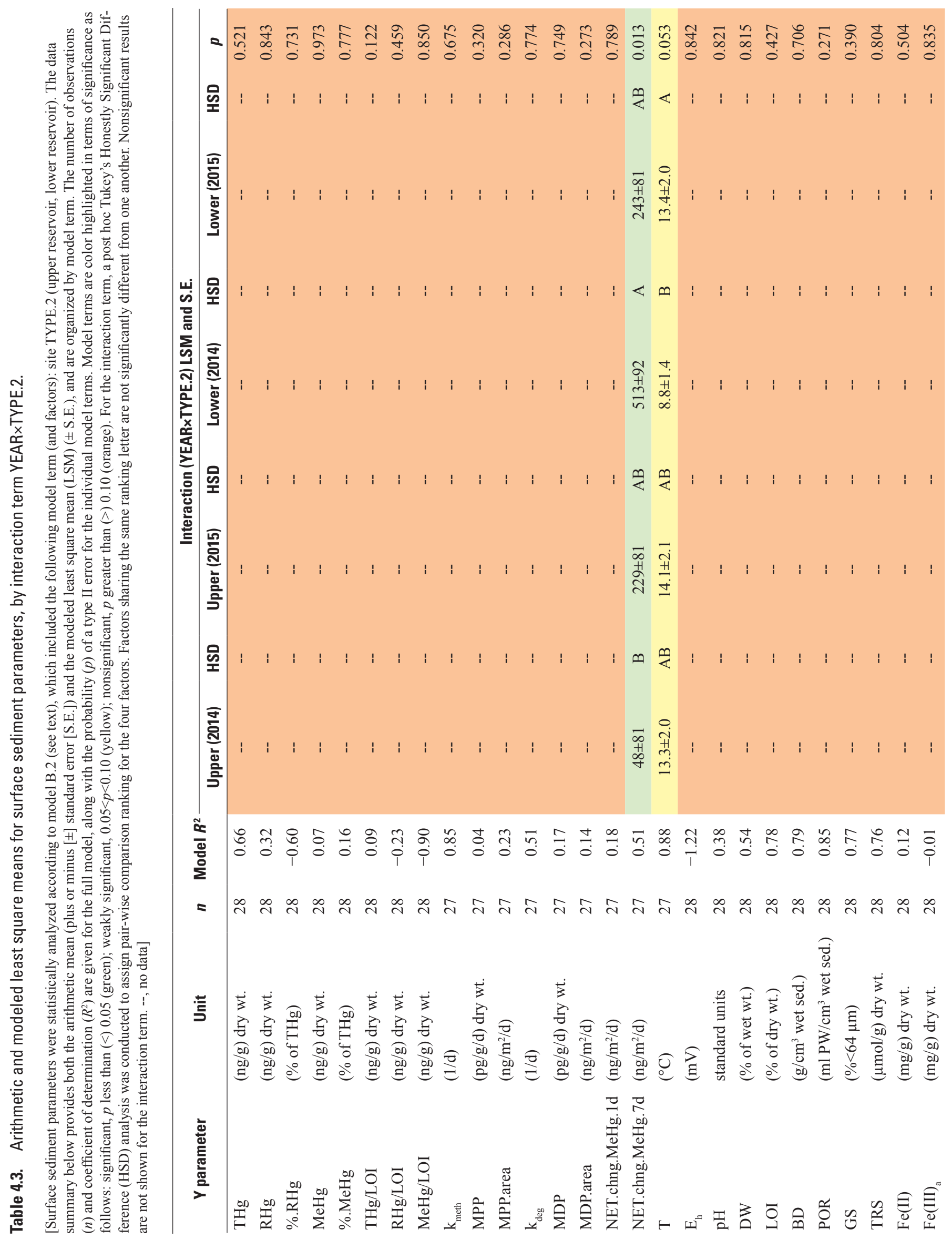




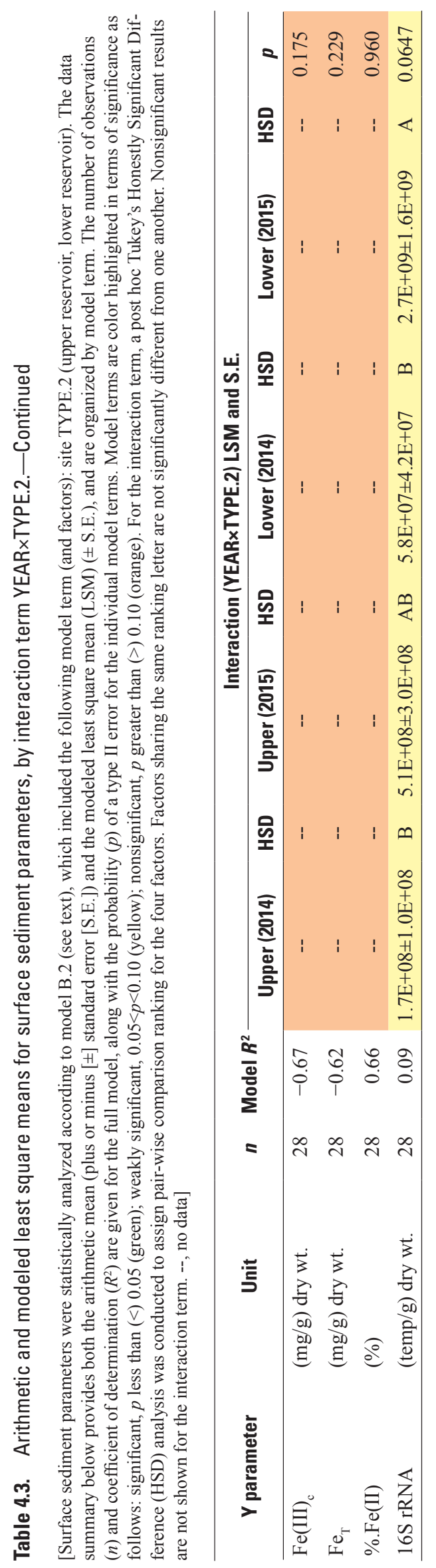




\section{Appendix 5. Arithmetic and Modeled Least Square Means for Plankton}

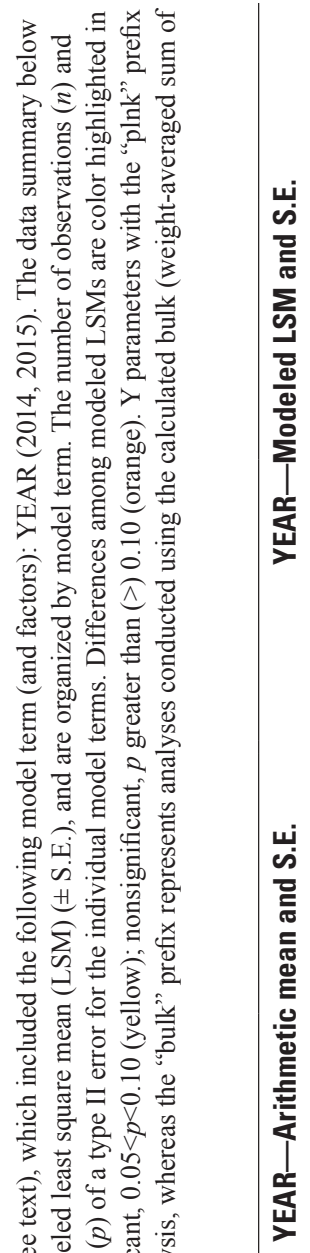

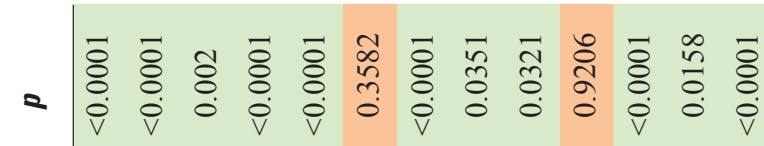

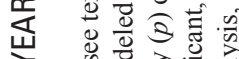

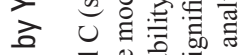

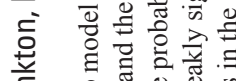

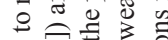

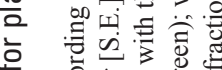

里

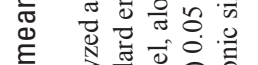

ำ

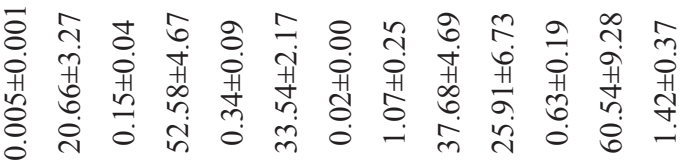

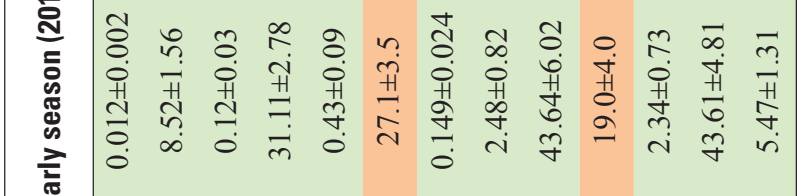

空

击开䓃吾

势焉焉

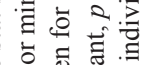

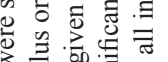

等

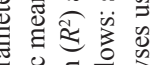

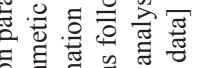

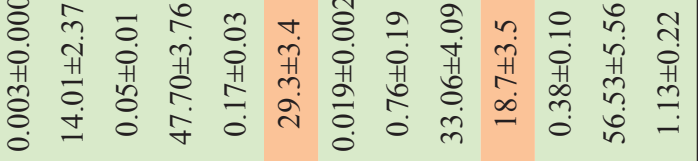

寻

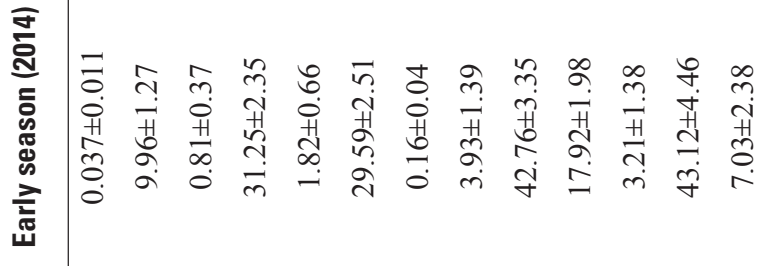

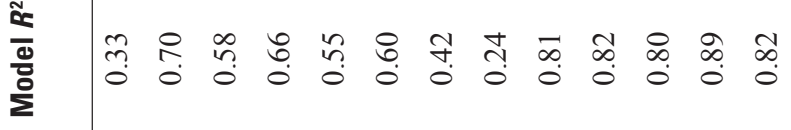

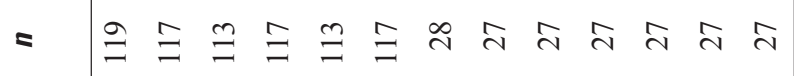

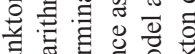

뜬,

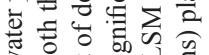

เं

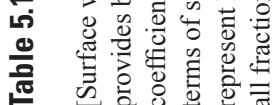

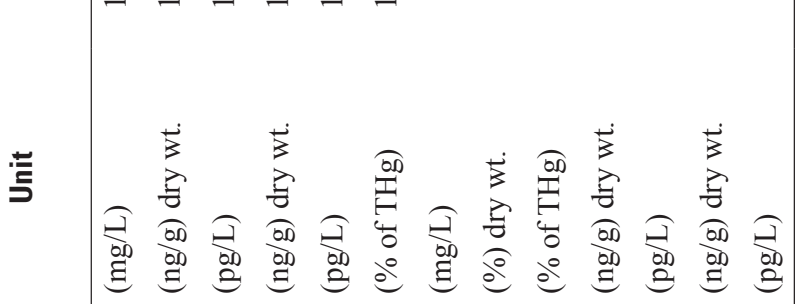

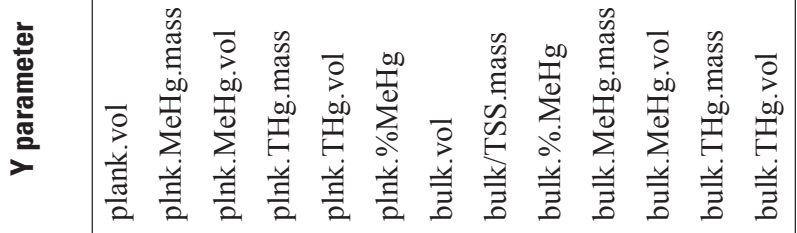




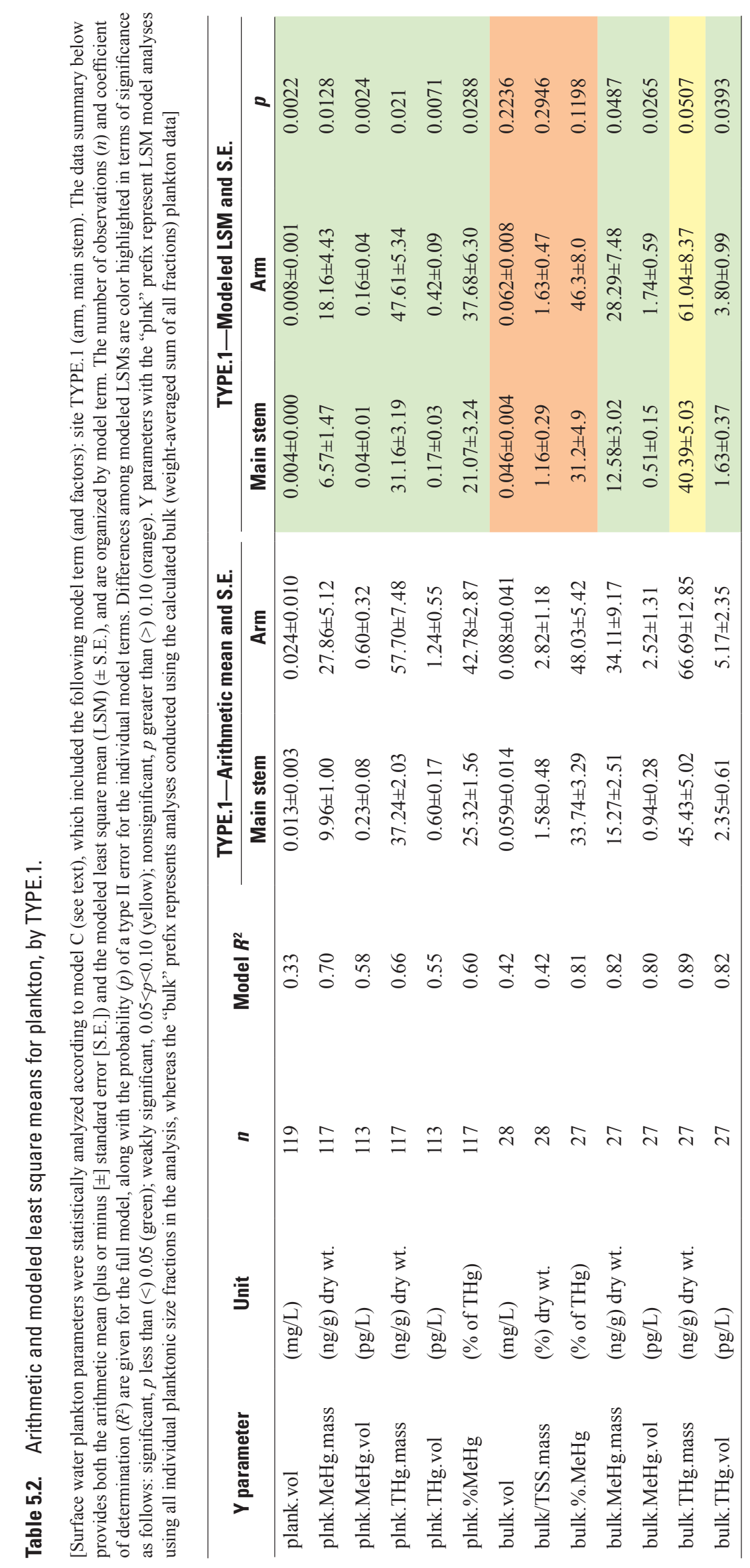




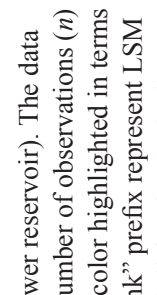

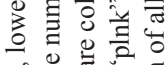

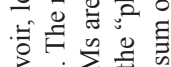

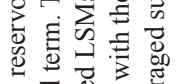

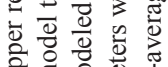

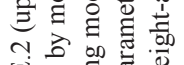

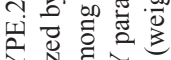

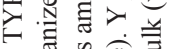

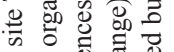

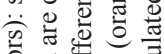

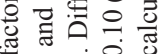

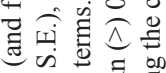

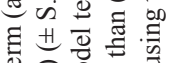

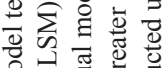

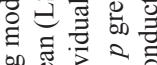

of

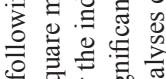

㻤

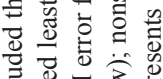

큰

일

학온 뚱은

นี่

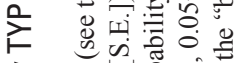

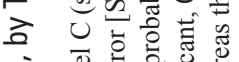

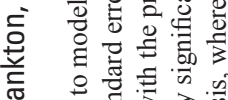

증 00 련

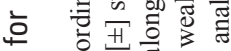

品

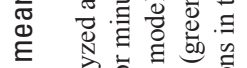

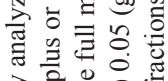

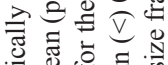

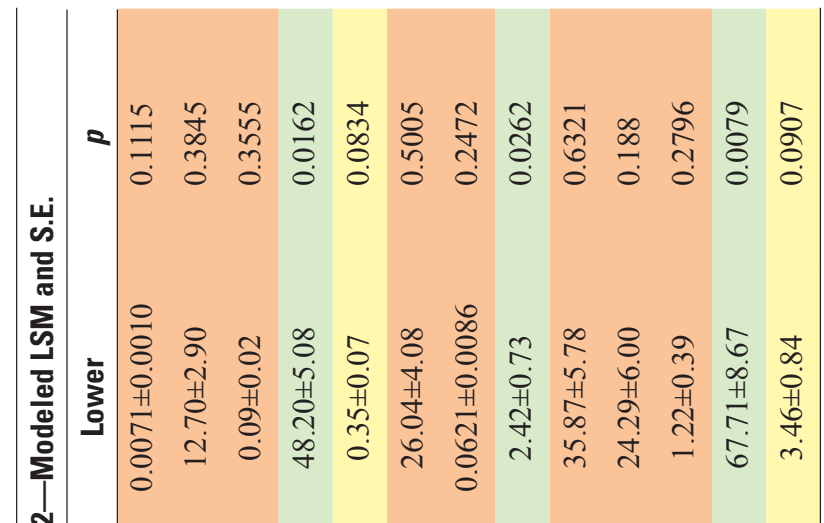

$\stackrel{\text { in }}{\gtrless}$

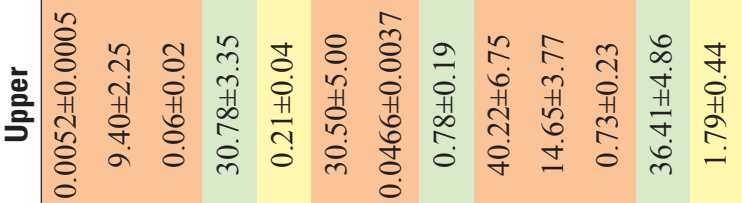

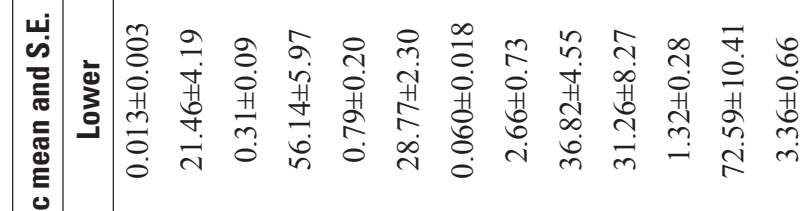

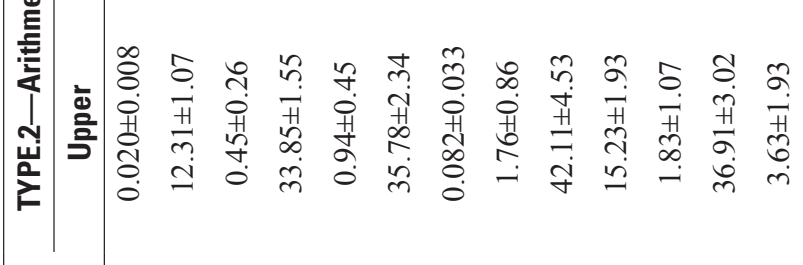

过

的的

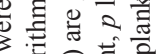

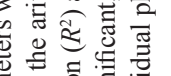

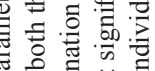

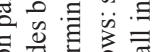

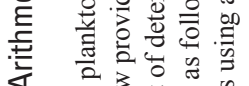

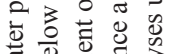

भं

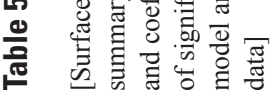

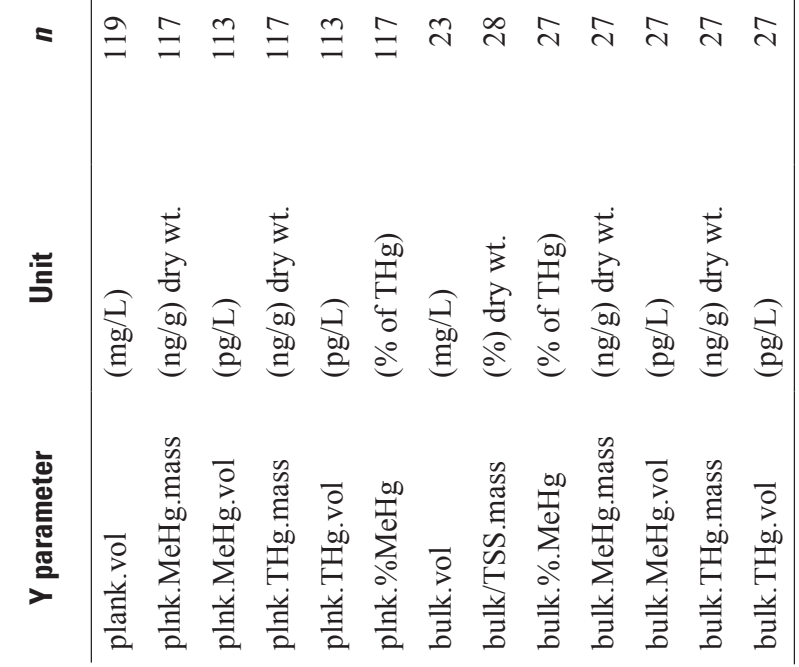




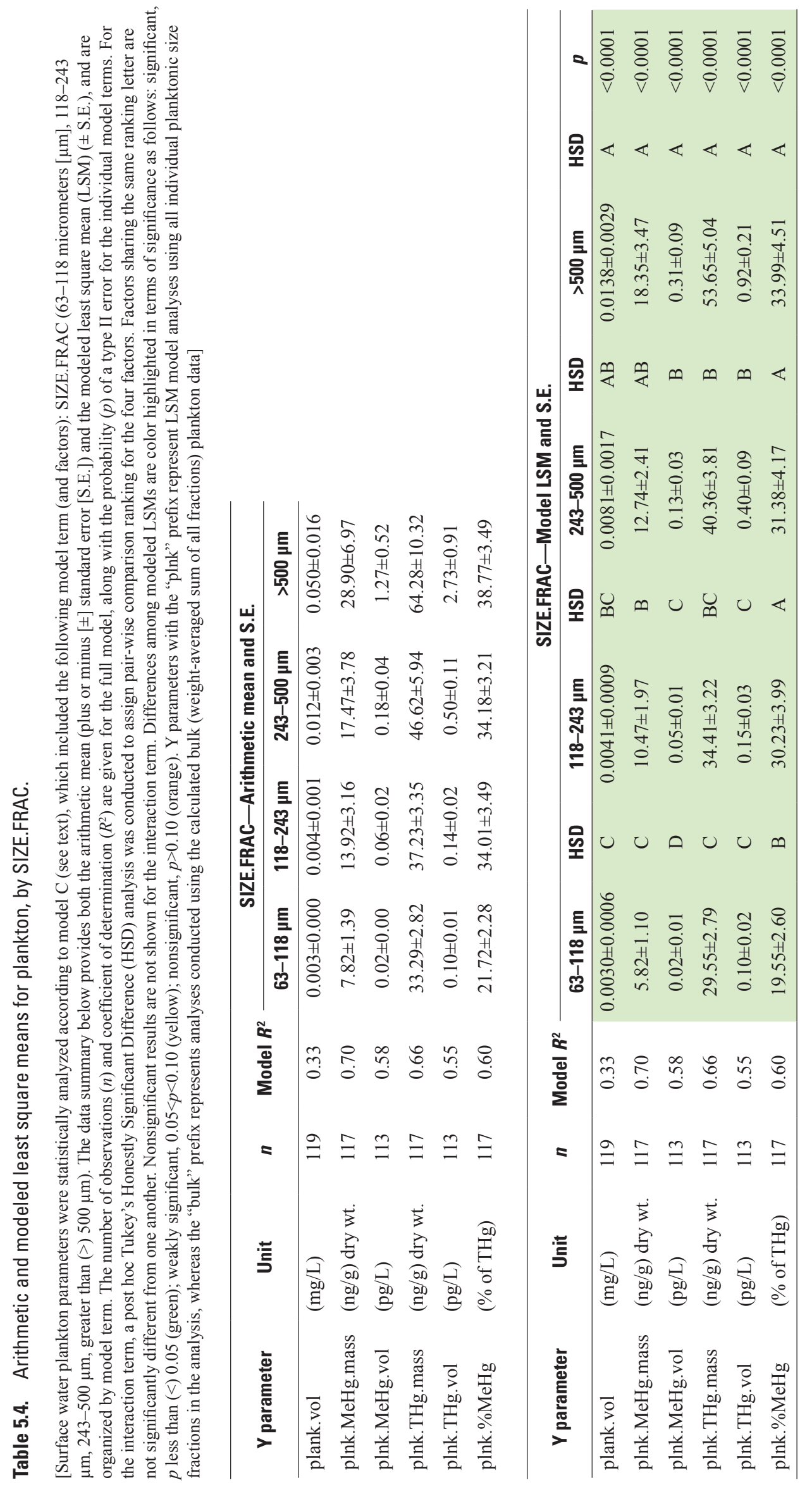




\section{Appendix 6. Arithmetic and Modeled Least Square Means for Striped Bass}

\section{Parameters}

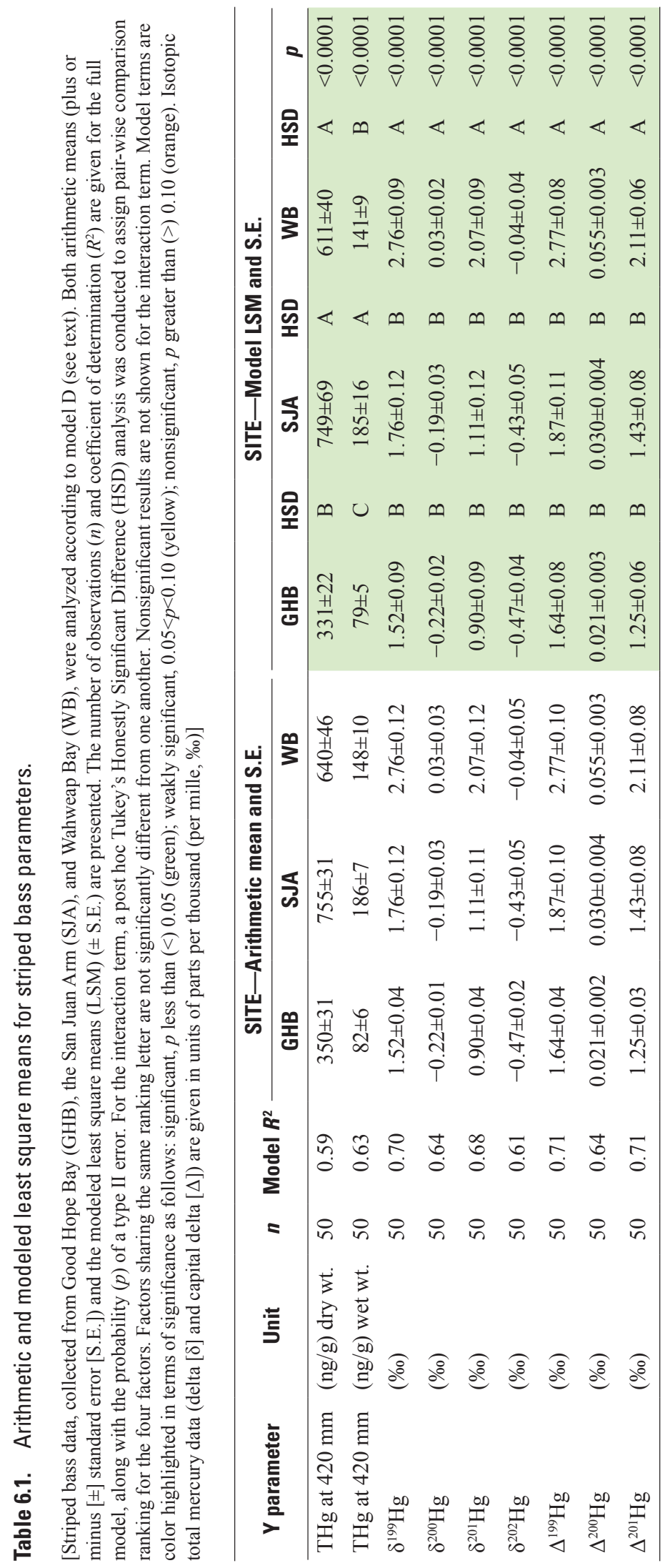


For more information about this publication, contact:

Director, USGS Utah Water Science Center

2329 West Orton Circle

West Valley City, UT 84119

801-908-5000

For additional information, visit: https://ut.water.usgs.gov/

Publishing support provided by the

Rolla Publishing Service Center 

